\title{
CARACTERIZAÇÃO E GÊNESE DE SOLOS BRUNOS DO MACIÇO ALCALINO DE POÇOS DE CALDAS (MG)
}

\author{
TARCÍSIO EWERTON RODRIGUES
}

Orientador: Prof. Dr. JOSÉ LUIZ IORIATTI DEMATTÊ

Tese apresentada à Escola Superior de Agricultura "Luiz de Queiroz", da Universidade de São Paulo, para obtenção do título de Doutor em Agronomia. Area de concentração: Solos $\theta$ Nutrição de Plantas.

PIR A C I A B A

Estado de São Paulo - Brasil

Agosto, 1984 
ii.

$\bar{A}$

memmōria de meu pai e irmãos;

a minha mãe e irmäos e, Sr. Raimundo

que muito contribuiram

para a minha formação

meu reconhecimento.

A

minha esposa silvia

$e$ minhas bilhas

sione e

Patricia

DEDICO. 
AGRADECIMENTOS.

- Ao Prof. Dr. José Luiz I. Demattê, pela orientação objetiva e constante durante o curso e na execução deste trabaIho;

- Ao Prof. Dr. Toshiaki Kinjo, pelạs sugestões e colaboraçãono desenvolvimento deste trabalho;

- Empresa Brasileira de Pesquisa Agropecuária (EMBRAPA), pe la oportunidade de realizar o curso e pelo suporte financeiro para execução deste trabalho;

- ÂAscola Superior de Agricultura "Luiz de Queiroz", da Universidade de São Paulo, pelos ensinamentos ministrados;

- Ao Serviço Nacional de Levantamento e Conservação de SolosEMBRAPA, pela realização de parte das análises físicas equí micas e ao Centro de Energia Nuclear na Agricultura - USP, pelas análises de. fracionamento da matéria orgânica;

- Aos Drs. Abeilard F. de Castro e Clotário Oliveira da Silveira, respectivamente, chefe e chefe adjunto-técnico do SNLCSolos, por viabilizaxem a realização do curso e desenvolvimento deste trabájho;

- Ao Prof. Dr. Carlos C. Cerri, pelas oportunas sugestões e observações ;

- Ao Dr. Marcelo Nunes Camargo, pelas sugestões e apoio recebido;

- Aos Drs. Humberto Gonçalves dos Santos, pela eficiente cola boração nos trabalhos de campo; Maria Amélia M. Duriez, Pau lo C. Lima, José P. Lima, pela colaboração prestada. 
- Ao Dr. Idarê Azevedo Gomes, pela amizade, apoio e colaboração;

- Ao Dr. Antonio C. Moniz, pelas sugestões e colaboração no desenvolvimento deste trabalho;

- Ao prof. Dr. Iede de Brito Chaves, pela revisão do texto;

- Aos técnicos de Laboratório, sr. Märio Benedito Lodovico e sra. Maria Elisabete H.B. Guimarães e à secretária sra. Nel ci Maniero, pelas suas valiosas contribuições;

- Aos professores, colegas e amigos pelo estímulo e apoio recebidos;

- A minha dedicada esposa Silvia, pela sua perseverança ao longo de uma carreira que nem sempre foi suave, e às minhas queridas filhas Sione e Patrícia, pelo estimulo positivo que resultou, constantemente, de suas preocupações pelo sucesso do pai. 


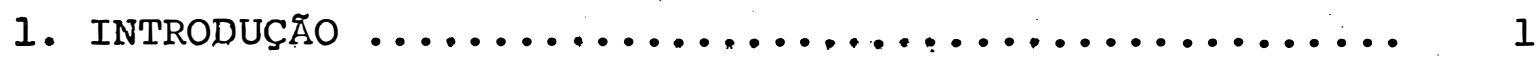

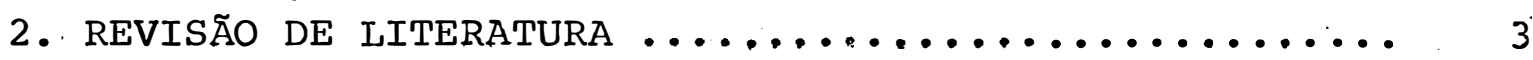

2.1. Caracteristicas dos solos .................. 3

2.2. Caracteristicas de cargas .............. 7

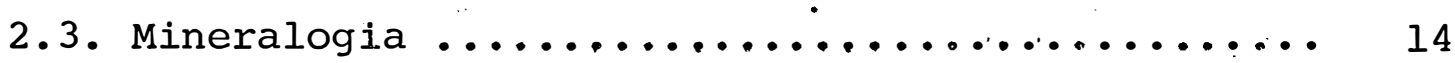

2.3.1. Mineralogia de argila ............. 14

2.3.2. Oxidos de ferro ................. 18

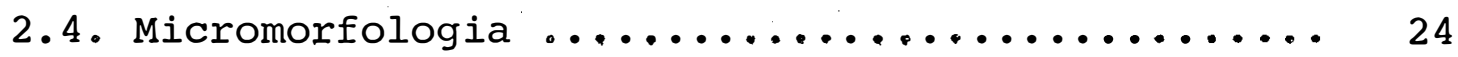

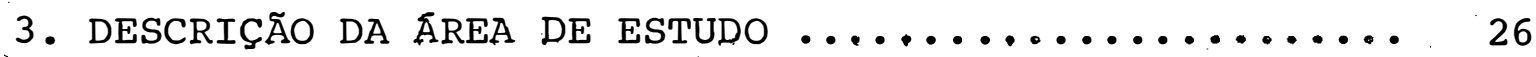

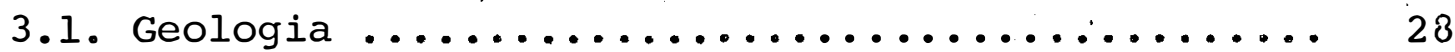

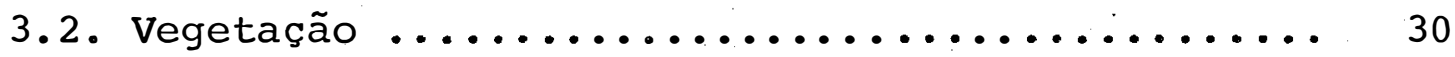

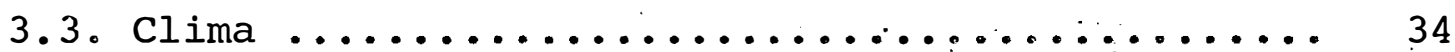

3.4. Geomorfologia (relêvo) ................ 35

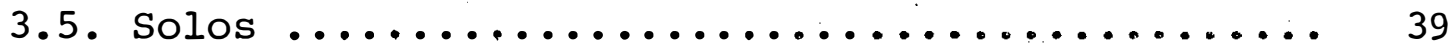

4. MATERIAL E MÉTOdOS ...................... 40

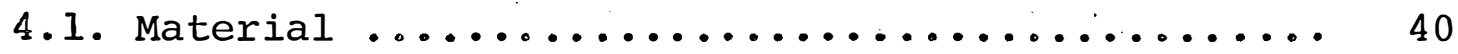

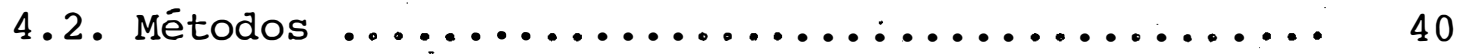

4.2.1. Análises físicas .............. 41

4.2.2. Análises químicas .............. 42

4.2.3. Análises mineralógicas ........... 44

4.2.4. Análise micromorfológica .......... 48

4.2.5. Classificação ................ 49

5. RESULTAdOS E DISCUSSÃo .......................... 50

5.1. Morfologia e distribuição dos solos ......... 51

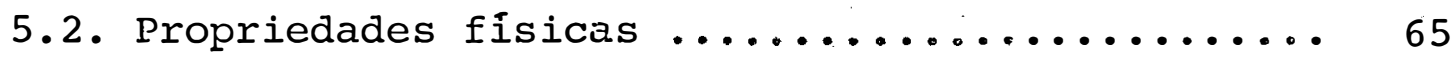

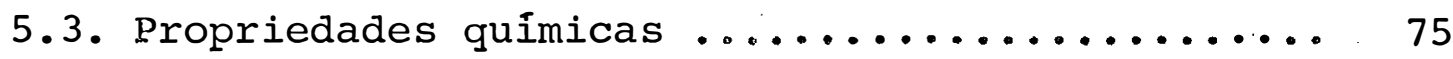

5.3.1. Matéria orgânica e tipo de humus ...... 75

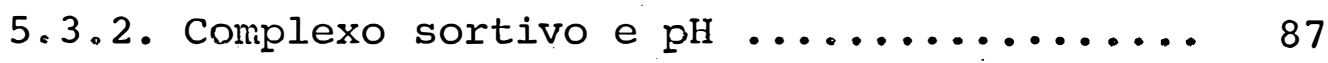

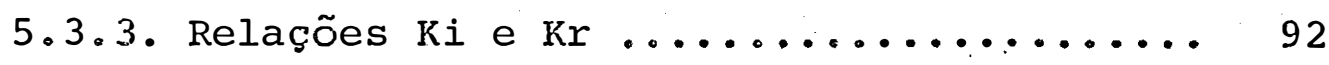

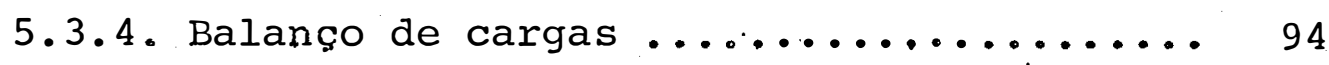

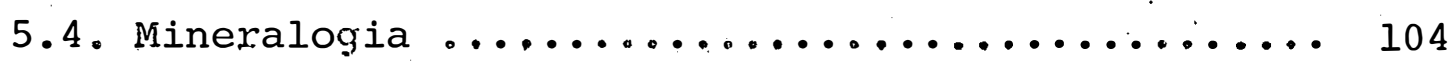

5.4.1. Oxidos de Érro, aluminio e manganês ... 104 
página

5.4.2. Mineralogia da fração areia ......... 119

5.4.3. Mineralogia da fração silte ......... 125

5.4.4. Mineralogia da fração argila ........ 129

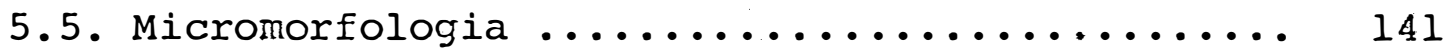

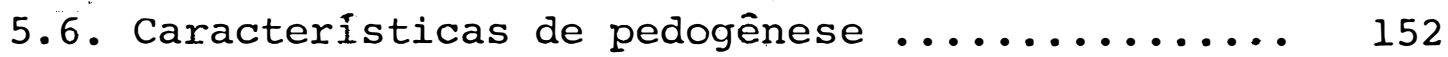

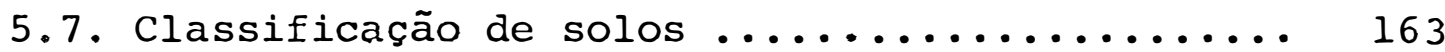

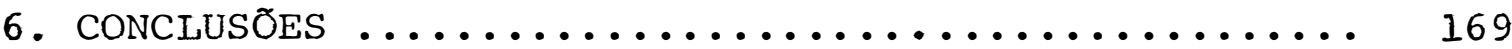

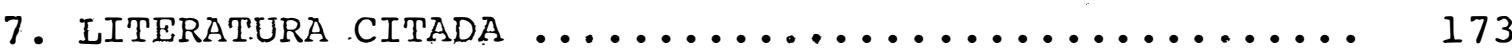

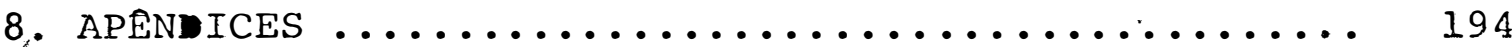


CARACTERIZAÇÃO E GÊIJESE DE SOLOS BRUNOS DO WACIÇO ALCALINO DE POÇOS DE CALDAS- (MG)

Candidato: TARCISIO EWERTON RODRIGUES

Orientador: Prof. Dr. JOSE LUIZ IORIATTI DEMATTE

RESUMO

O presente trabalho foi conduzido com a finali dade de obter informações sobre a caracterização e gênese de solos Brunos encontrados no maciço alcalino de poços de Caldas-MG. Foram amostrados oito perfis de solos desenvolvidos de rochas alcalinas no maciço de poços de Caldas. Tais perfis estão dispostos ao longo de duas sequências catenarias, ou seja, sequência I com os perfis PC-1, PC-2, PC-3 e PC-4 e a sequência II com os perfis PC-5, PC- 6 , PC-7 e PC-8. Tais solos apresentam coloração predominantemente brunada, associada com uma estrutura pequena a grande em forma de bloco subangular em grau moderado. As análises físicas e químicas incluíram além da.s análises de rotina, a retenção de água, superfície específica, cargas elétricas e óxidos de Fe, Al e $\mathrm{Mn}$. No estudo da composição mineralógica das frações do solo foram empregados Raios-X, DTA e mëtodos óticos.

Os solos são argilosos a muito argilosos, ācidos, argila de baixa atividade e álicos, com estrutura no horizonte B latossolico em grau moderado e fraco; de coloração brunada nos matizes lOYR a 5YR. Os valores de superfície espe cífica $(64$ a $187 \mathrm{~m} / \mathrm{g})$ são elevados para solos de mineralogia 1:1, refletindo a influência de materiais amorfos, mica e ma- 
téria orgânica, no complexo coloidal destes solos. O comportamento eletroquímico destes solos é regido pelo sistema de cargas variáveis, devido as cargas dependentes de $\mathrm{pH}$ presentes na superfície das caulinitas e óxidos de Fe e Al. Nestes solos ocorrem tanto cargas negativas como positivas no $\mathrm{pH}$ do solo. A goethita como Al-substituição $(23$ a 57 mole \% na fra ção argila) é a principal responsável pela coloração brunada destes solos.

A composição mineralógica destes solos é constituída predominantemente por caulinita, gibbsita, material amorfos (alofanas) e mica. Em pequenas percentagens são encontrados vermiculita com hidroxila interlamelar, quartzo, óxidos de titanio e feldspatos. A gibbsita encontra-se em duas formas: gibbsita primária I nas frações areia e silte, formadas pela alteração direta de feldspatos e a gibbsita secundāria II, formada pela dessilicatização da caulinita. A cau linita é originada da alteração direta do feldspato, ressilica tização de gibbsita I e dessilicatização da mica. A associação da caulinita com microcristais de gibbrita, altamente ani sotrópico, na matriz do solo, confere a estes, uma estrutura plásmica predominantemente sépica.

Os teores de óxidos de ferro total ( $\leq 9 \% \mathrm{Fe}_{2} \mathrm{O}_{3}$ ) e a presença de horizonte B latossólico ou óxico, permitem en quadrar a maior parte destes solos nas classes dos Latossolos Brunos e Vermelhos Amarelos. A única distinção entre eles se-ria a estruturação mais evidente nos perfis PC-1, PC-2, PC-4, PC-7 e PC-8. Entretanto, tal critério não é distintivo entre classes de solos no sistema brasileiro de classificação. A cria ção de um subgrupo dentro dos Latossolos que incluissem os so los semelhantes as Terras Brunas Estruturadas, serviria para grupar justamente os solos com características oxídicas, porëm, com estrutura mais desenvolvida. 
CHARACTERIZATION AND GENESIS OF BROWN SOILS FROM ALCALINE ROCKS OF POÇOS DE CALDAS (MG)

Candidate: TARCISIO EWERTON RODRIGUES

Adviser: Prof. Dr. JOSE LUIZ IORIATTI DEMATTE

SUMMARY

This study was carried out with the objective to obtain informations on characteristic and genesis of Brown Soils originated from alcaline rocks of Poços de Caldas-MG. Eight profiles of these soils were selected for this study. Such profiles are located in two toposequences: sequence I with profiles designated PC-1, PC-2, PC-3 and PC-4; sequence II with profiles PC-5, PC- $6, \mathrm{PC}-7$ and PC- 8 . These soils have predominantly brownish coloring, together with fine to coarse subangular blocky structure in moderate grade. The physical and chemical analyses included, besides those of routine analyses, water retention, specific surface, electrical charge, and oxides of $\mathrm{Fe}, \mathrm{Al}$, and $\mathrm{Mn}$. In the study of the mineral composition of the soil fractions, raios-X, DTA, and optical methods were used.

The soils are clayey to very clayey, acid, low activity clay, and alic. The B horizon is characterized by a weak a moderate subangular blocky structure and a brownish color with hues ranging from 5YR to 10YR. The values of specific surface area (64 to $187 \mathrm{~m} / \mathrm{g}$ ) are high for soils with 1:1 type mineralogy, reflecting the influence of amorphous material, mica, and organica matter in the colloidal complex 
of these soils. The electrochemical behavior of these soils is governed by the variable charge system, due to the presence of pH-dependent charges on the surface of the kaolinite and the oxides of $\mathrm{Fe}$ and $\mathrm{Al}$. In these soils occurs negative charge as well as positive charge at the pH of the soil. The goethite with Al-substitution (23 to 57 mole 8 in the clay fraction) is mainly responsible for their brownish color.

The mineralogical composition of these soils is constituted predominantly by kaolinite, giblusite, amorphous material (allophane), and mica. Exist in small percentages, vermiculite with interlaminar hydroxide, quartz, oxides of titanium, and feldspats. The gibbsite existe in two forms: primary gibbsite $I$ in the sand and silt fractions, formed by the direct alteration of feldspats and secondary gibbsite II, formed by the dessilication of the kaolinite. The kaolinite in originated from the direct alteration of the feldspats, ressilication of gibbsite $I$, and dessilication of the mica. The association of the kaolinite with microcrystalline gibbsite, highly anisotrofic, in the soil matriz, gives rise to plasmic structure, predominantly sépic to these soils.

Total iron oxides contents ( $\left.\leq 9 \% \mathrm{Fe}_{2} \mathrm{O}_{3}\right)$ and the presence of latosolic or oxic $B$ horizon allow to include a large part of these soils in the classes of Brownish Latosols and Red Yellow Latosols. Only one distinction among them would be the more evident structure in the profiles PC-1, PC-2, PC-4, PC-7 and PC-8. However, such criterion is not distinctive among soils classes in the Brazilian Soils Classification System. Establishment of one subgroup within the Latosols that could include soils similar to structured Brown Earth, would serve to include those soils with oxidic characteristics, but with more developed structure. 


\section{INTRODUÇÃO}

Os solos estudados neste trabalho são origina dos de rochas alcalinas do maciço de Poços de Caldas - Estado de Minas Gerais, que apresentam características morfológicas semelhantes às Terras Brunas Estruturadas e aos Latossolos Brunos, identificados no sul do Brasil (EMBRAPA, 1980aeb). Tais solos são caracterizados, principalmente em relação à cor bru nada e a estrutura em bloco subangular pequena a grande de grau moderado, bastante evidente no horizonte B. $O$ aspecto desta estrutura, torna-se mais evidente nos cortes secos de estrada, onde o processo de umedecimento e secamento tem agido com mais frequência. Estes solos fazem lembrar a Terra Roxa Estruturada, caracterizada em diversas regiões do Brasil. Diferem destas, no que diz respeito, principalmente, quan to às características de cor. Enquanto que, as Terras Roxas Estruturadas possuem cores nos matizes em torno de 2,5YR a 10R, os solos da região de Poços de Caldas apresentam cores no horizonte $B$, nos matizes 5YR a 10YR.

O estudo referente à caracterização e gênese dos solos, torna-se esșencial no que se refere, respectivamente, ap conhecimento da composição mineralógica e a alteração e tranș 
formação que o material de origem dos mesmos sofreu. Tais informações permitirá o estabelecimento de relações úteis referentes ao comportamento físico e químico dos solos, bem como, fornecerá subsídios para classificação e levantamento mais detalhados, informações estas imprescindíveis ao aproveitamen to racional destes solos para a agricultura e pecuária.

Esta pesquisa reveste-se de particular interes se, porque os salos a serem estudados são semelhantes a outros, desenvolvidos de rochas do derrame basáltico no sul do Brasil, permitindo assim, que seja feita uma correlação entre os mesmos. Alēm disso, as informações detalhadas de suas propriedades e a distribuição na paisagem, tambēm, fornecerá subsídios à complementação do Levantamento de Solos na região compreendida pelo sul de Minas Gerais, realizado pelo Serviço Nacional de Levantamento e Conservação de Solos - SNLCS/EMBRAPA. Os objetivos deste trabalho são:

a. caracterizar a morfologia e as propriedades físicas, químicas e mineralógicas dos solos;

b. relacionar os solos na paisagem, inclusive sua pedogênese;

c. correlacionar as propriedades das

Terras Brunas Estruturadas e os Latossolos Brunos com os solos de outras regiões do Brasil;

d. classificar os solos. 


\section{'2. REVISÃO DE LITERATURA}

\subsection{Características dos solos}

Na maioria dos levantamentos de solos até então efetuados, foram estudados principalmente características morfológicas, físicas e químicas dos principais solos que ocorrem no Brasil. A seguir serão apresentadas caracterîsticas distintivas das principais classes de solos encontrados na área de estudo,como: Latossolo Bruno, Latossolo Vermelho Amarelo, Ter ra Bruna Estruturada, Cambissolo, Latossolo Roxo e Terra Roxa Estruturada.

Os Latossolos caracterizam-se por serem alta mente intemperizados, ter baixa reserva de minerais intemperizáveis, uma baixa capacidade de retenção de cátions e horizontes com diferenção pouco evidente. São solos profundos, com horizonte B latossólico, de textura média, argilosa e muito argilosa,com presença ou não de concreções e/ou nódulos lateríticos ao longo do perfil. São bem a excessivamente drenados, porosos, frija a veis a muito friáveis, com estrutura granular muito pequena a pequena e média bloco subangular. O incremento de argila do horizonte A para o horizonte B é gradativo, não demonstrando evidência de acúmulo de argila. 
Normalmente são de fertilidade natural baixa, contudo, podem ser encontrados eutróficos, distróficos e álicos; com cargas variáveis dependentes de $\mathrm{pH}$, ácidos a muito ácidos. A argila é de baixa atividade com capacidade de troca de cátions menor que 13 me/100 g de argila após correção para carbono. A relação molecular $\mathrm{SiO}_{2} / \mathrm{Al}_{2} \mathrm{O}_{3}$ (Ki) é normalmente baixa, com valores variando de 0,4 a 2,0 , evidenciando o elevado grau de intemperização dos materiais destes solos. Os materiais óxicos.nos latossolos são constituidos principalmen te de minerais secundários de argila do tipo 1:1 (caulinita), óxidos de ferro e aluminio (goethita, hematita e gibbsita) e quartzo e, em pequenas proporções mica, óxidos de titânio (ana tasio e rutilo) e muscovita-vermiculita: .

Os Latossolos apresentam coloração variando de bruno a vermelho escuro nos matizes lOYR a 10R, cujas cores do horizonte $\mathrm{B}$ relacionadas aos teores de óxidos de ferro totais $\left(\mathrm{Fe}_{2} \mathrm{O}_{3}\right.$ do ataque sulfúrico) contidos nos solos são consi derados no estabelecimento das seguintes classes: Latossolo Bruno, Latossolo Amarelo, Latossolo Vermelho Amarelo, Latos solo Vermelho Escuro e Latossolo Roxo (BENNEMA e CAMARGO, 1964). As classes de Latossolos que ocorrem na área do maciço alcali no de Poços de Caldas são principalmente o Latossolo Bruno e o Latossolo Vermelho Amarelo.

Os Latossolos Brunos desenvolvidos de rochas do derrame basáltico no sul do Brasil (BRASIL, 1973; POTTER, 1977; LIMA, 1979; EMBRAPA, 1980a e b), caracterizam-se por serem ácidos, medianamente profundos a profundos e bem a moderadamen te drenados. A coloração do horizonte $B$ destes solos varia de bruno escuro a vermelho amarelado, nos matizes 5YR a 10YR. O horizonte A é bastante espesso com elevado teor de matéria orgânica. Estes solos são normalmente muito argilosos, com estrutuxa fracamente desenvolvida em bloco subangular e/ou granu 
lar e presença de cerosidade fraca e pouca. A capacidade de troca de cátions encontra-se entre 5,6 a $21,5 \mathrm{me} / 100 \mathrm{~g}$ de so1o, com os valores mais elevados no horizonte A devido aos al tos teores de matéria orgânica.

Possuem teores relativamente altos de óxidos de ferro e titânio variando normalmente de 15 a $20 \%$ e de 2,6 a $5,7 \%$, respectivamente. Os valores da relação $\mathrm{SiO}_{2} / \mathrm{Al}_{2} \mathrm{O}_{3}$ estão em torno de 1,7 a 2,13 (BRASIL, 1973; POTTER, 1977; LIMA, 1979; EMBRAPA, 1980a e b) evidenciando a dominância nesses so los de minerais de argila do tipo $1: 1$.

Os Latossolos Vermelhos Amarelos caracterizamse principalmente pela coloração amarelo avermelhado a vermetho amarelado, compreendidas nos matizes 7,5YR e 5YR, com teo res de óxidos de ferro total $\left(\mathrm{Fe}_{2} \mathrm{O}_{3}\right.$ - ataque sulfürico) nor malmente inferiores a 9 \% ; desenvolvidos geralmente de material retrabalhado proveniente dos mais diversos tipos de rochas. São em geral muito profundos, de textura média a muito argilosa, com estrutura fraca pequena granular a moderada mui to pequena a pequena bloco subangular, friáveis e muito porosos. Normalmente são distróficos e álicos, contudo são encon trados os tipos eutróficos, com soma de bases e capacidade de troca de cátions baixas:

Os Latossolos Roxos são desenvolvidos de material proveniente de rochas básicas, são ácidos, muito profundos, bem drenados, possuindo teores elevados de óxidos de $\therefore$ ferro (ataque sulfúrico) normalmente superiores a $20 \%$ A colora ção é vermelha escura nos matizes $2,5 \mathrm{YR}$ a 10R. Normalmente são eutróficos, mas podem ser distróficos, de textura argilosa, com estrutura muito pequena granular, muito friáveis e muito porosos. 
As Terras Roxas Estruturadas são solos desenvolvidos de material oriundo de rochas básicas, com horizonte B textural, apresentando diferença textural nẳo significa tica entre os horizontes A e B. São profundos, de coloração vermelha a vermelha escura nos matizes $2,5 \mathrm{YR}$ a $10 \mathrm{R}$, com altos teores de óxidos de ferro, manganês e titânio, e argila de ati vidade baixa. São normalmente eutróficas, mas ocorre a varia ção distrófica, e talvez a variação álica. As Terras Roxas Estruturadas desenvolvidas de outros tipos de rochas apresen tam coloração vermelha escura de menor intensidade e são denominadas de Terra Roxa Estruturada Similar.

As Terras Brunas Estruturadas identificadas no sul do Brasil (EMBRAPA, $1980 \mathrm{a}$ e b) comprendem solos minerais, com horizonte B textural e argila de atividade baixa, com teo res altos de óxidos de ferro e titânio, desenvolvidos de mate riais procedentes de rochas do derrame do Trapp, no sul do Bra sil. São de coloração brunadà, profundos a medianamente profundos, bem drenados, com incremento gradativo de argila do horizonte A para o B, resultando num baixo gradiente textural. São semelhantes à Terra Roxa Estruturada, diferindo desta quan to à coloração bruna do horizonte B, menos espessura do solum e menor grau de desenvolvimento de estrutura e de cerosi dade.

Os Cambissolos são intimamente relacionados ao caracter do material de origem, com horizonte B incipiente ou câmbico, pouco profundos com presença ou não de materiais facilmente intemperizāveis, saturação de bases e de alumínio al ta ou baixa, argila de atividade alta ou baixa, com capacidade de tronca de cātions (T) maior que $12 \mathrm{me} / 100 \mathrm{~g}$ de argila após correção para carbono, fortemente a medianamente ácidos, bem a moderadamente drenados. Diferenciam-se dos solos com B textural, por não apresentarem, cerosidade, acumulação signi- 
ficativa de óxidos, humus e argila no horizonte subsuperficial; e dos Latossolos pela pouca profundidade, presença de minerais facilmente intemperizáveis e pela atividade de argila.

Outros solos que podem ser destacados, são os intermediários entre duas classes de solos, no caso, os Latossolos câmbicos onde há dominância de características diagnóstí cas dos Latossolos e os Cambissolos latossólicos onde predomina as características dos Cambissolos. Além destes, podem ocor rer os Podzólicos Vermelhos Amarelos que se apresentam nas variedades eutróficas e distróficas de textura média ou argilo sa, ácidos a muito ácidos, com B textural e argila de atividade alta ou baixa. Os Litossolos são pouco desenvolvidos, rasos, com horizonte A de coloração normalmente preta. Os solos Hidromórficos caracterizam-se pela influência da água, pela os cilação do lençol freático condicionado pelo relevo e drenagem, evidenciado pelo acúmulo superficial de matéria orgânica e tạ bém pela presença de cores cinzas, resultante do processo de redução que caracteriza a gleização nesses solos.

Na Tabela 1 são apresentadas as médias e variações de algumas propriedades dos Cambissolo, Latossolo Bruno, La tossolo Vermelho Amarelo, Latossolo Roxo e Terra Roxa Estruturada, para efeito de correlação e comparação com os dados obtidos dos solos aqui estudados, com a finalidade de clas sificā-los de acordo com os sistemas brasileiro e americano de classificação de solos.

\subsection{Caracteristicas de cargas}

As propriedades de troca de íons são influencia. das pelas cargas elétricas dos colóides dos solos, as quais são de vital importância ao manejo e utilização adequada dos solos 


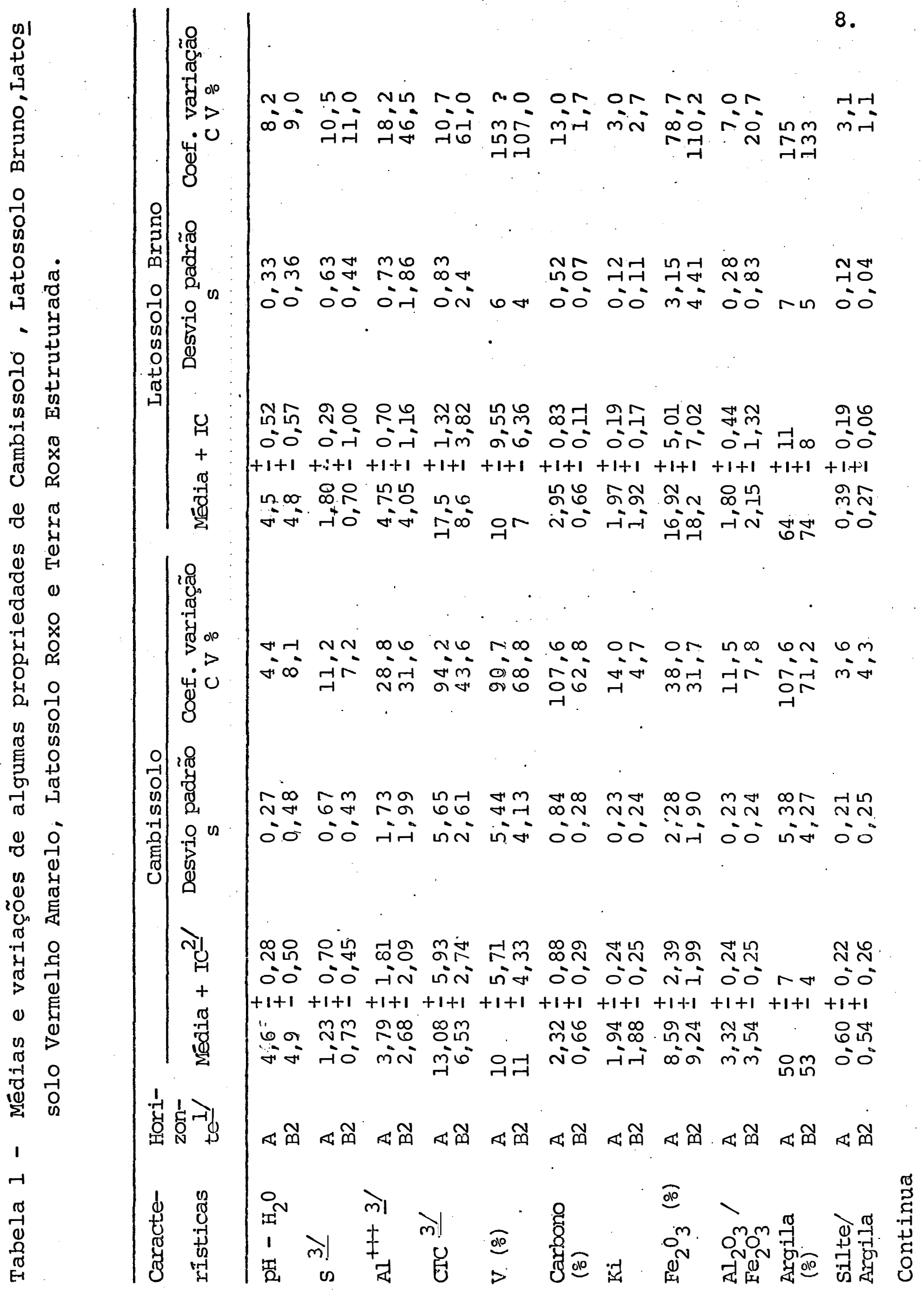




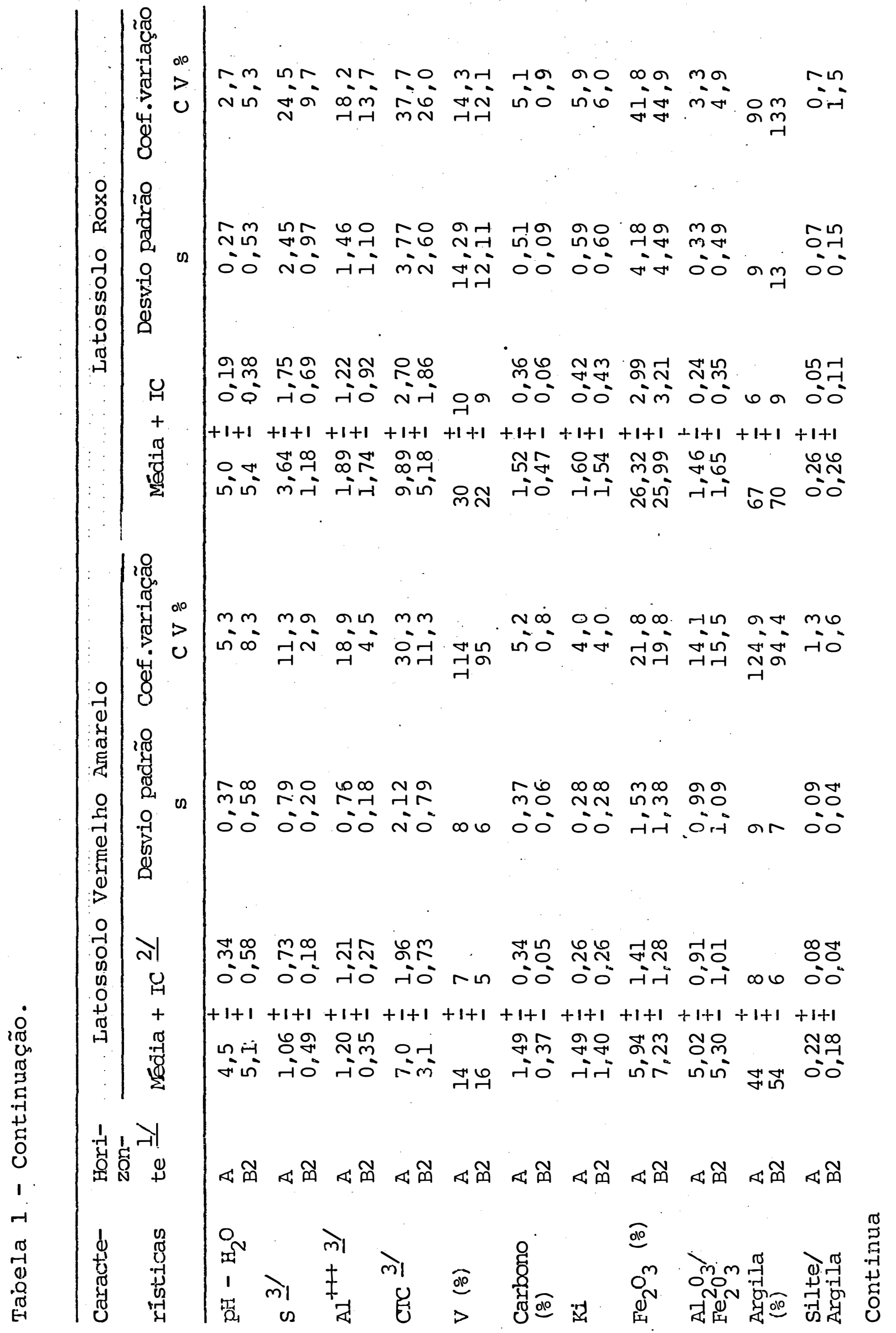




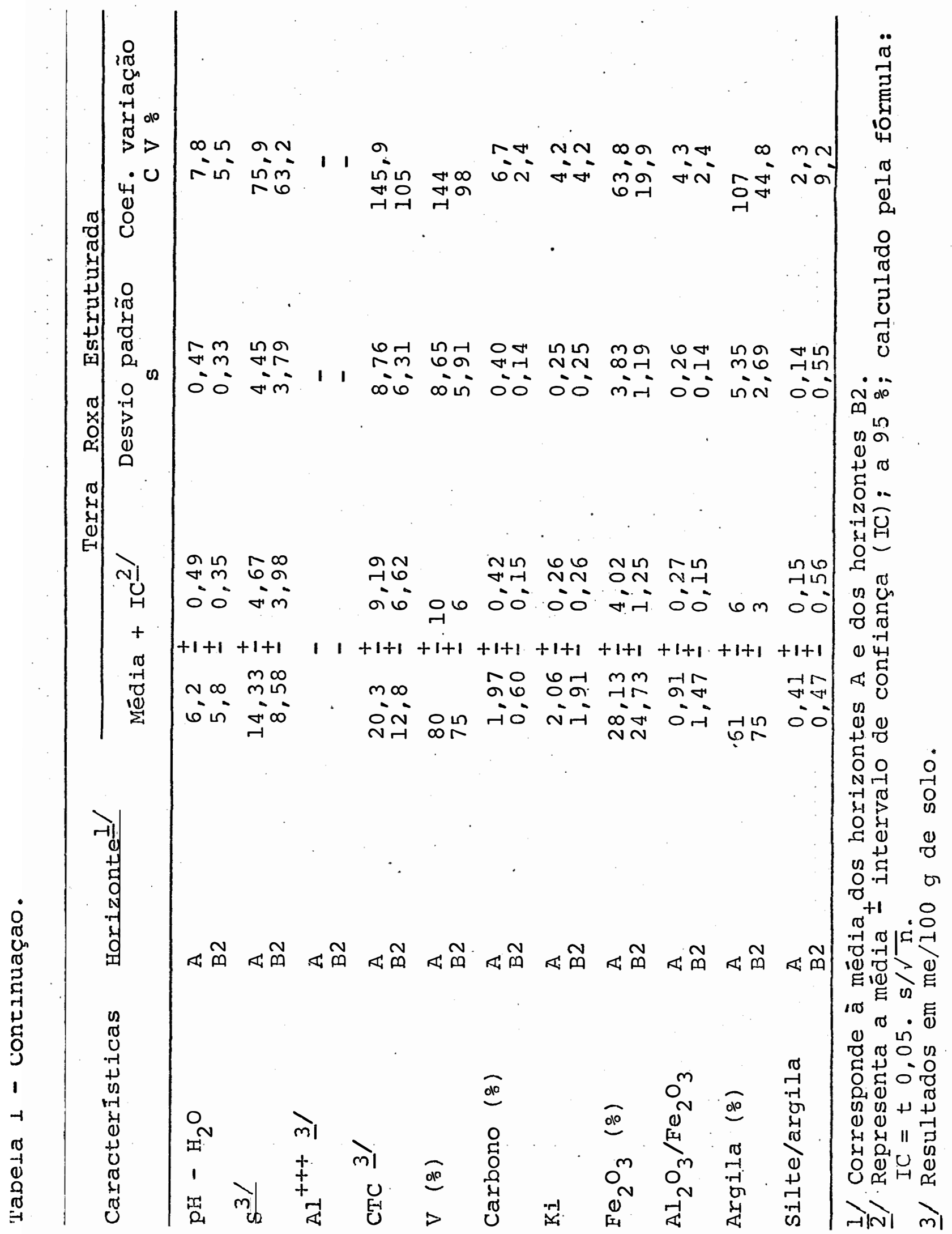


tropicais para propósitos agrícolas. Os solos dos trópicos úmidos são caracterizados pelos sistemas de cargas variáveis- potencial de superfície constante (VAN RAIJ e PEECH, 1972 ; MORAIS et alii, 1976). Em tais sistemas, o potencial de superfície permanece constante e a carga da superfície varia com as mudanças na concentração eletrolítica e na atividade dos îns $\mathrm{H}^{+}$e $\mathrm{OH}^{-}$, determinantes de potencial (VAN OLPHEN, 1963).

Nos solos tropicais altamente intemperizados há predominância de caulinita, óxidos e hidróxidos de Fe e Al na fração argila. Contrastando com os argilo minerais smectitas e vermiculitas, estes minerais normalmente não possuem nenhuma quantidade apreciável de cargas negativas permanente. A magnitude da carga de superfície de óxidos minerais não depende somente do $\mathrm{pH}$, mas também da natureza e concentração dos eletrolitos na solução do solo (GALLEZ et alii, 1976).

Os colóides dos solos das regiões temperadas ou solos com mineralogia $2: 1$, geralmente apresentam superfícies de carga permanentes (constantes), enquanto que aqueles das re giões tropicais normalmente têm cargas de superfície variáveis (potencial de superfície constante) (VAN RAIJ e PEECH, 1972) • Os óxidos e hidróxidos de $\mathrm{Fe}, \mathrm{Al}, \mathrm{Ti}$ e Mn, bem como, o quartzo, sílica amorfa e caulinita são minerais de carga superficial va riável (UEHARA e KENG, 1975).

PARKS e BRUYN (1972) admitiram dois tipos de du pla camada elétrica em base no mecanismo pelo qual as cargas livres são distribuídas através a interface solução-sólido,sen do (i) una dupla camada reversível que existe na superfície pro duzindo cargas variáveis, e (ii) uma dupla camada completamente polarizada que ocorre nas superfícies possuindo cargas permanentes. O sistema de cargas variáveis aplica-se principal - 
mente aos óxidos e hidróxidos de Fe e Al, enquanto que o sistema de carga permanente é aplicado aos minerais silicatados, tais como, as smectitas e vermiculitas, as quais possuem superfície de cargas negativa permanente devido a substituição isomórfica (VAN RAIJ e PEECH, 1972; KENG e UEHARA, 1974).

A principal referência usada para descrever 0 -sistema de cargas variáveis é o ponto de carga zero (PCZ). O PCZ é definido como o pH no qual a carga líquida de superfície de todas as fontes é zero (PARKS e BRUYN, 1952).

VAN RATJ e PEECH (1972) reportando curvas de $\mathrm{pH}$ de carga de superfície de alguns alfissolos e oxissolos (do Brasil) concluiram que o comportamento dos solos estudados foi similar àqueles mostrados por muitos óxidos metálicos. MORAIS et alii (1976) estudando a distribuição de cargas elétricas em oxissolos, ultissolos e alfissolos (do Brasil) constataram que o comportarnento eletroquímico destes foi similar ao sistema de cargas variāveis, sendo os íons $\mathrm{H}^{+}$e $\mathrm{OH}^{-}$determinantes de potencial na solução de equilíbrio, com variação na distribui ção de cargas com o pH e concentração eletrolítica.

VAN RAIJ e PEECH (1972) observaram que os valo res de PCZ variavam nos solos de $\mathrm{pH} 1,9$ a 3,6 para o horizonte $A$ e de $\mathrm{pH} 2,7$ a 6,0 para o horizonte B. MORAIs $\cdots$ et alii (1976) constataram que $O$ PCZ dos solos variou de 1,2 a 3,4 nos horizontes $\mathrm{A}$ e de 4,0 a 6,1 nos horizontes $B$. A dife rença marcante entre os horizontes de cada solo, com mineralo gia semelhante, deve ser atribuída ao elevado teor de matéria orgânica do horizonte A quando comparado ao horizonte $B$ correspondente (VAN RAIJ e PEECH, 1972; MORAIS et alii, 1976). KENG e UEHARA (1974) estudando alguns oxissolos e ultissolos do Hawai, observaram que O PCZ desses solos variaram de 4 a 6 , com O PCZ dos oxissolos sendo mais altos que nos ultissolos. 
GALLEZ et alii (1976) observaram que solos da Nigéria também apresentam curvas de pH de superfície de carga semelhante aos óxidos metálicos, indicando que o comportamento dos solos segue o sistema de cargas variáveis. Os valores de PCZ variaram de 3,0 a 3,9 para alfissolos e ultissolos, com valores de PCZ geralmente mais altos nos horizontes subsuperficiais.

Normalmente, o PCZ decresce com uma elevação no conteúdo de matéria orgânica e de minerais tendo substitui ção iscmórfica elevada e aumenta com a quantidade de óxidos de $\mathrm{Fe}$ e Al presentes, porque estes materiais adquirem mais cargas positivas em $\mathrm{pH}$ baixo (PARFITT, 1980).' De modo que GALLEZ et alii (1976) constataram que O PCZ do solo reflete o seu grau de intemperismo químico ou grau de dessilicatização, assim como, as características de cargas de óxidos de Fe e Al no solo, na seguinte ordem alfissolos < ultissolos < oxissolos com valores médios de $\mathrm{pH}$ de 3,$4 ; 4,0$ e 5,0, respectivamente.

Considerando os resultados obtidos por VAN RAJJ e PEECH (1972); KENG e UEHARA (1974); MORAIS et alii (1976) e GALLEZ et alii (1976); torna-se evidente que os solos tropicais (alfissolos e ultissolos de argila de atividade baixa e oxissolos) normalmente apresentam cargas variāveis dependente de $\mathrm{pH}$, assim como, alguma cárga negativa permanente.

Os solos com grande quantidade de cargas variā veis, como os oxissolos e outros solos tropicais fortemente lixiviados, precisam ser manejados diferentemente dos solos com superfície de carga constante. Isto se deve porque os so los com cargas variáveis apresentam propriedades físicas e químicas diferentes daqueles com carga permanente (PARFITT, 1980 ). 
As teorias sobre os mecanismos de adsorção e fenômenos de cargas em solos de cargas variáveis são apresentados, na revisão sobre este assunto por BOWWEN et alii. (1980).

\subsection{Mineralogia}

2.3.1. Mineralogia de argila.

Os estudos de mineralogia do solo reveste-se de grande importância, não só para a caracterização do solo, como também, nas relaçõeș entre seus componentes e o meio ambiente visando caracterizar os processos pedogenéticos e as sequên cias de alteração des minerais em formação do sojo. O conhecimento dos minerais da fração argila é indispensável aos estudos de gênese dos solos e importante na classificação e ao uso agricola. Os argilo minerais são resultantes da ação rea tiva dos materiais primārios às energias do meio durante um determinado tempo (KELLER, 1970). Os minerais de argila en contrados nos solos podem ser ou herdados do material de origem ou resultantes da alteração direta dos minerais primários ou ser sintetizados durante o desenvolvimento do perfil. do so 1o.

A composição mineralógica da fração argjila dos Latosisolos compreende em geral os seguintes minerais: caulinita, gibbsita, materiais amorfos, óxidos de ferro livre, ver miculita, clorita, mica e quartzo (JUNGERIUS e LEVELT, 1964 ; MONIZ E JACKSON, 1967; MOURA FILHO e BUOL, 1972; LE ROUX,1973; WEAVER, 1974; LEPSCH et alii, 1977; RODRIGUES, 1977; POTTER, 1977; DEMATTÊ, 1975; KAMPF e KLAMT, 1978 e LIMA, 1979). KAMPF e KLAMT (1978), LIMA (1979) e POTTER (1977) encontraram tam bém minerais 2:l em estágio avançado de cloritização, cristobalj.ta e feldspatos plagioclásios. MOURA FILHO e BUOL (1972), WEAVER (1974) e RODRIGUES (1977) constataram ainda a presença. 
de óxidos de titânio e minerais de argila do tipo 2:2. A exis tência de feldspatos na fração argila mostra um grau pouco in tenso de intemperização ou adição de material primário a solos velhos, enquanto que os ōxidos de titânio indicam um gṛau avançado de alteração (JACKSON e SHERMAN, 1953).

Na fração argila de alguns Latossolos há dominância da caulinita e em outros da gibbsita. Os teores elevados de gibbsita nesses solos estão relacionados à alteração de minerais primārios e caulinita à gibbsita. (GALHEGO e ESPIN DOLA, 1976) e resultante da sintese de caulinita e materiais amorfos concomitante com a alteração desses minerais em gib bsita (MONIZ e JACKSON, 1967 e MONIZ e OLIVEIRA, 1974).

Nos estudos mineralógicos conduzidos em solos Terra Roxa Estruturada foi constado que na fração argila des ses solos os principais minerais encontrados são: caulinita,

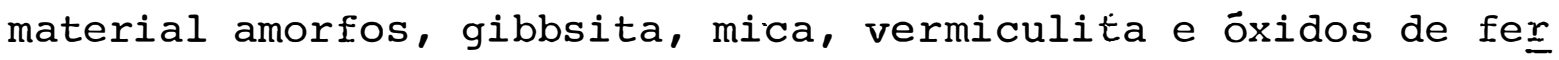
ro (MONIZ e JACKSON, 1967; MONIZ e OLIVEIRA, 1974; ANDRADE et. alii, 1976 e ALOISI et alii, 1976). MONIZ e OLIVEIRA (1974) e ANDRADE et alii. (1976) constataram tambëm a presença de mont. morilonita. MONIZ e OLIVEIRA (1974), considerando a gibbsita como mineral indice para avaliação da intensidade de intemperismo, constataram que as Terras Roxas Estruturadas estariam em estāgio menos intemperizados que os Latossolos, devido con terem teores mais baixos em gibbsita.

MONIZ e JACKSON (1967) consideram que a sequên cia de intemperismo para estes últimos solos seria feldspatos $\rightarrow$ mica $\rightarrow$ caulinita e material amorfos (alofana) $\rightarrow$ gibbsita, parecendo ser uma tendência geral para solos tropicais (JACKSON et alii, 1948). 
A presença de mica nesses solos, segundo MONIZ e JACKSON (1967), deve-se a alteração de feldspato que é controlada pela quantidade de $\mathrm{K}$ disponível no material primário. A mica poderia sofrer intemperismo alterando-se a caulinita pe la liberação de K (BATES, 1960). A alteração de feldspatos em mica foi observada em seções finas de rochas básicas por MELFI e GIRARDI (1962).

A composição mineralógica da fração argila de Cambissolos compreende os seguintes minerais: caulinita, materiais amorfos (alofana), gibbsita, mica, vermiculita, clori ta e óxidos de ferro (MONIZ e OLIVEIRA, 1974; POTTER, 1977; DECHEN, 1979 e LIMA, 1979). Foi encontrado também montmorilo nita (MONIZ e OLIVEIRA, 1974); quartzo (POTTER, 1977; DECHEN, 1979 e LIMA, 1979) e a presença em pequenas quantidades de cristobalita e feldspatos (LIMA, 1979).

A presença de argilo-minerais 2:1 cloritizados, em solos altamente intemperizados, têm sido constada em quantidades apreciāveis (DE VILLIERS e JACKSON, 1967; LE ROJUX, 1973; RODRIGUES, 1977; POTTER, 1977 e MOLLER e KLAMT, 1982).. Segundo LE ROUX (1973) a aluminação das entre-camadas dos minerais 2:1 reduz a capacidade de troca e confere uma maior es tabilidade em meío ácido, cuja presença nos oxissolos (latossolos) é prevista na Soil Taxonomy (ESTADOS UNIDOS - SOIL TAXONOMY, 1975). A origem dos minerais cloritizados pode ocorrer pela degradação de cloritas ou pela cloritização de vermi culitas e montmorilonitas, de maneira que em solos ácidos e bem drenados há possibilidade da precipitação de polímeros de aluminio nos espaços interlaminares dos filossilicatos (MOLLLER e KLAMT, 1982). 
Nos Latossolos normalmente não são encontradas ver miculitas e montmorilonitas, uma rez que as condições de equi líbrio nesses solos não favorecem a estabilidade das mesmas, conforme demonstrou KITTRICK (1969). Enquanto que, a presença de vermiculita e montmorilonita nos Cambissolos e Terras Roxas Estruturadas, refletem as condições de equilíbrio favoráveis à estabilidade destes minerais, pela existência de um teor mais elevado de cátions e silício na solução do solo. A ocorrência destes minerais de argila em solos tropicais submetidos ao processo de dessilicatização gradual e intensiva (JACKSON e SHERMAN, 1953) podem representar uma fase intermediária na alteração da mica, em caulinita, e posteriormente gibbsita, desde que pequenas quantidades de vermiculita e montmorilonita sejam encontradas nesses solos. A explicação para existência nesses solos de vermiculuta $\dot{e}$ montmorilonita, seria a manutenção do alto teor de silício na solução do solo, pela presença do quartzo, que parece funcionar como fonte de silício (GORDERT et alii, 1976).

MONIZ (1969) estudando a composição mineralógi ca de argilas do maciço alcalino de poços de Caldas, encontrou mica, caulinita, gibbsita e também halloisita, estabelecendo a seguinte sequência de intemperismo para as rochas alcalinas: rochas alcalinas (feldspato) $\rightarrow$ mica $\rightarrow$ caulinita e material amorfos $\rightarrow$ gibbsita. A alteração do feldspato em mica é controlada pelo conteúdo de $\mathrm{K}_{2} \mathrm{O}$ do material primário, no caso de rochas alcalinas (cerca de $7 \%$ de $\mathrm{K}_{2} \mathrm{O}$ ) irá formar um alto con teúdo de mica secundária. O mesmo autor também atribui a formação de cau linita e gibbsita pela alteração direta do feldspato, assim como, a ressilicatização da gibbsita para formar caulinita.

ANTONELLO (1982) estudando solos do maciço alcalino de Itatiaia, constatou que a fração argila e ra consti tuída de caulinita, gibbsita, vermiculita, mica; haloisita e óxidos de ferro (goethita). Também observou que a gibbsitiza ção dos minerais primários deu-se de maneira direta e indire- 
tamente, do mineral original por uma fase de material amorfo ou de caulinita a gibbsita, respectivamente.

\subsubsection{Oxidos de ferro}

Os óxidos e hidróxidos de ferro e alumínio nas formas cristalinas e amorfas, e na forma de complexos orgânicos, estão entre os principais componentes dos solos tropicais. Os óxidos de ferro estão normalmente dispersados através da massa do solo na forma de partículas finamente dividida e possivelmente como revestimento de superfícies de outros minerais de argila.

A distribuição no perfil das diversas formas de Fe e Al têm sido utilizada como critério na interpreta ção dos processos de formação do solo e na definição de gran des grupos e/ou classes de solos (MCKEAGUE e DAY, 1966: MCKEA GUE, 1967; BLUME e SCHWERTMANN, 1969; MCKEAGUE et alii,1971). Os óxidos de ferro nos solos são normalmente estimados através de métodos analíticos: o método de oxalato de amônio áci do, proposto por MCKEAGUE e DAY (1966) que é presumível remo ver os óxidos de ferro amorfos ao raios-X e os complexos orgânicos e somente pequena parte dos óxidos cristalinos; o mé todo do citrato-bicarbonato-ditionito de sódio recomendado por MEHRA e JACKSON (1960) que remove os óxidos de ferro cristalinos, além disso, as frações extraídas pelo oxalato de amônio (MCKEAGUE e DAY, 1966 e McKEAGUE et alii, 1971).

A diferença entre os valores de óxidos de ferro obtidos pelos dois métodos representa a quantidade de ferro presente na forma de óxidos cristalinos. A relação Fe (Fe-oxalato/Fe-ditionito) ativo tem sido utilizada para . demonstrar a presença de óxidos de ferro cristalinos nos solos, 
uma vez que a relação Fe ativo decresce com o aumento da idade do solo (ALEXANDER, 1974).

A ocorrência natural de óxidos de ferro, geral mente contendo algum Al, evidencia a substituição de $\mathrm{Fe}$ por Al na estrutura de goethita e hematita (NORRISH e TAYLOR, 1961 ; JANOT e GIBERT, 1970; DAVEY et alii, 1975). A substituição do Al é reportada causar redução no tamanho de partículas, co mo também, nas dimensões da célula unitária đa goethita e hematita (NORRISH e TAYLOR, 1961).

BIGHAN et alii (1978a) observaram que a goethi ta em oxissolos é altamente substituída, com conteúdos de Al estrutural em torno de 30 a 40 moles por cento, enquanto que em ultissolos constataram que a goethita é menos substituída, com conteúdo de Al em torno de 14 a 28 moles por cento.

MONIZ et alii (1982) estudarido solos de duas topossequências baseados nos teores de óxidos de ferro extraí dos com oxalato- $\mathrm{NH}_{4}$ e dithionito (CBD) constataram que a subs tituição de Al nos óxidos cristalinos dos solos da topossequên cia de Itatiba foi da ordem de'10 a 30 moles por cento, enquan to que nos solos da topossequência de Mogi-Guaçú alcançou 27 a 46 moles por cento, sendo portanto mais elevados que os observados para Itatiba e os reportados por BIGHAN et alii (1978a) e FITZPATRICK e SHWERTMANN (1982).

A presença de óxidos de ferro nos solos consti tuídos de goethita e hematita, contendo quantidades elevadas de Al estrutural, além de decrescer o tamanho de partículas dos óxidos de ferro, também aumenta sua estabilidade e área superficial especifica, indo influir nas propriedades, tais 
como, dissolução e estabilidade de agregados (JANOT e GIBERT, 1970; BIGHAN et alii, 1978a e POMBO et alii, 1982).

FITZPATRICK e SHWERTMANN (1982) relatam que o grau de substituição de Al e a cristalinidade da goethita podem refletir o meio ambiente no qual elas foram formadas e serviriam çomo indicador dos processos de formação do solo • Consideram que a alta substituição de Al em goethita, em solos fortemente ácidos (acima de 32 moles \%) seria devido ao alto grau de intemperismo, que cria una alta disponibilidade de Al. As goethitas formadas sob condições hidromórficas e mesotrófí cas (solos fracamente ácidos) apresentam substituição de Al mais baixas (0-15 moles \%) do que aquelas sob condições não hidromórficas, fortemente intemperizados e mais àcidos (15-32 mo les $\%)$. A razão para esta tendência seria o aumento de ativí dade do $\mathrm{Al}$ quando $\mathrm{o} \mathrm{pH}$ decresce,e, consequentemente, o aumento na disponibilidade de Al a ser incorporado na estrutura da goethita a ser formada.

TORRENT et alii (1980) estudando-a mineralogia do ferro de alguns solos na Espanha, concluiram que a substi tuição de Al na goethita calculada de difratogramas de raios$-\mathrm{X}$, aumentou com a idade do solo, refletindo no aumento .. da acidez dos solos.

ASHAYE (1969) estudando solos da Nigéria concluiu que a quantidade e natureza das várias formas de óxidos de $\mathrm{Fe}$ e Al e complexos orgânicos de $\mathrm{Fe}$ e Al podem influenciar consideravelmente as propriedades físicas e químicas dos solos.

As propriedades dos solos referentes a sorção de ânions, superfície de troca, superfície específica, expan- 
são e formação de agregados podem ser grandemente modificadas pela presença de óxidos de Fe e Al amorfos (ACRA e WEED,196o; DESHPAND et alii, 1968 e GREENLAND et alii, 1968). SHERMAN et alii. (1964) observaram que os óxidos amorfos submetidos a secagem em temperatura elevada sofreram desidratação e subsquente mudança para um sistema de maior cristalinidade. Constata ram também a evidência que a perda de materiais amorfos nos solos tropicais, resultante da desidratação e cristalização , resultaram em mudanças significativas em certas propriedades físicas e químicas do solo, tais como, decréscimo na capacida de de troca de cátions e aumento de densidades.

Os óxidos de ferro devido à sua quantidade, sua diversidade de tipo e graus de cristalinidade e pela considerável influência nas propriedades físicas e químicas dos solos, tem sido utilizados na diferenciação de classes de solos, como é o caso do teor de óxidos de ferro extraídos com $\mathrm{H}_{2} \mathrm{SO}_{4}$ $\mathrm{d}=1,47$, na distinção de latossolos (BENNEMA e CAMARGO,1964). $O$ uso do teor total de óxidos de ferro extraídos com $\mathrm{H}_{2} \mathrm{SO}_{4}$ $\mathrm{d}=1,47$ como característica diagnóstica principal na distinção de classes de solos, não deveria ser recomendado, tendo em vista que o teor total de ferro no solo, não explica os processos pedogenéticos de formação do solo, assim como, a mi neralogia do ferro.

KAMPF e SCHWERTMANN (1983) estudando relações entre óxidos de ferro e a cor do solo, concluiram que a cor do solo é determinada pelo tipo de óxido de ferro e principal mente pela concentração de hematita presente. RESENDE (1976) constatou que a cor de um oxissolo amarelo foi alterada de l0YR para 5YR, quando misturado com somente $1 \%$ por peso de hemati ta finamente pulverizada. Da mesma maneira DAVEY et alii (1975) reportaram que o óxido de ferro dominante em alguns solos pod zólicos vermelhos e amarelos típicos da Austrália é goethita 
aluminosa. Os solos vermelhos também continham hematita fina mente dividida, a qual efetivamente mascara a cor da goethica.

BIGHAN et alii (1978b) estudando ultissolos da Carolina do Norte e oxissolos do Brasil, com a finalidade de determinar como as cores desses materiais foram influenciados pela natureza e distribuição dos óxidos de ferro constituin tes, constataram que os óxidos de ferro estavam concentrados na fração argila, e que as cores destas argilas foram as mesmas ou similares a aquelas dos solos. A goethita ou mistura de goethita e hematita foram identificadas em todas as argi las, entretanto, as análises indicaram que os membros verme lhos de todas as amostras pares continham maiores proporções de hematita do que suas contrapartidas amarelas. Além disso, quando as argilas tornaram-se mais vermelhas em matiz, a rela ção de hematita/goethita geralmente aumentava. As argilas amarelas foram também mais eficientes absorvidores de fosfato por unidade de peso que suas contrapartidas vermelhas. Os va lores de superfície específica nas argilas amarelas foram con sistentemente mais altos do que aqueles de suas contrapartidas vermelhas (nos materiais vermelhos).

Através dé dados acumulados de hematita e goethita sintéticas SCHWERTMANN e TAYLOR (1977) defenderam que as variações nà quantidade de ânions e/ou cátions adsorvidos especificamente por estes óxidos, foram originados principalmen te das diferenças na superfície específica, do que, das diferen ças composicional ou estrutural.

VOLKOFF (1978) estudando os produtos ferrugino sos que determinam a cor dos latossolos, constatou que a cor amarela està diretamente associada à presença de goethita, in dependente da quantidade, enquanto que a cor vermelha refere-se à presença de hematita, principalmente quando esta se en- 
contra sob a forma de cristais muito pequenos ou imperfeita mente formados. E que a cor dos latossolos depende diretamen te da natureza e da cristalinidade dos produtos ferruginosos e não das quantidades de óxidos de ferro. De maneira que o teor de óxidos de ferro total ou ferro livre de um solo não devé ser usado como critério único na distinção de classes de solos através da cor, tendo em vistia que solos de cores amare las podem apresentar teores bastante elevados de óxidos de ferro e os de cores vermelhas nem sempre contém os teores mais elevados em óxidos de ferro.

A presença de goethita e de hematita em Latossolos Vermelhos Escuros e apenas goethitas nos vermelhos amarelos foram observadas também por WEAVER (1974) e RODRIGUES (1977) .

SCHWERTMANN et alii. (1982) atribuiram que solos com matizes 7,5-5YR ou mais vermelhos devem suas cores vermelhas principalmente à hematita, enquanto que solos com matizes lOYR ou mais amarelas usualmente contém. goethita, e são livres de hematita. A distribuição geográfica de solos vermelhos (hematiticos) e solos bruno-amarelos (livres de hematitas) parece estar estreitamente relacionada ao clima, de maneira que aumentos de temperaturas aparentemente favorecem a formação de hematita pedogenética (rubification).

VOLKOFF e RIBEIRO (1979) constataram que latos solos vermelhos da Bahia apresentam caulinita associada com goethita e principalmente hematita. Nos solos podzólicos ver melhos observaram que o material de alteração contém minerais de argila 2:l e goethita; e que a cor vermelha se desenvolve gradativamente, ao mesmo tempo que as smectitas desparecem e se processa a transformação de goethita em hematita. Conclui 
ram que um meio onde os cátions básicos são facilmente lixi viados leva à formação de hematita e caulinita, enquanto que, em meio rico em bases favorece a formação de smectitas e goethitas.

Considerando que os latossolos apresentam duas cores fundamentais, uma vermelha e outra amarela, a suposição de que os solos vermelhos fossem mais ricos em ferro que os amarelos, nem sempre tem sido verificada. As. cor relações estabelecidas tanto na Africa (Maignien, 1958 citado por VOLKOFF, 1978), como no Brasil (BENNEMA, 1966) demonstram ser muito difícil estabelecer subdivisões de solos (latossolos e podżólicos) segundo o critério baseado na relação teor de $\mathrm{Fe}_{2} \mathrm{O}_{3} / \mathrm{cor}$ (VOLKOFF, 1978).

Assim, as diferenças na mineralogia do ferro, como o refletido na cor do solo, é provavelmente um critério bastante significativo para separações não só taxonômica, como também, referente ao manejo dos principais solos tropi cais altamente intemperizados.

\subsection{Micromorfologia}

A análise micromorfológica aplicada ao estudo de solos tem sido utilizada como meio adicional, dígno de confiança, para elucidar problemas relacionados à gênese de solos (BREWER, 1976; ESWARAN, 1972), em estudos de identificação de camadas estratigráficas nos solos (BREWER, 1972a; FINKL Jr. e GILKES, 1976) e na identificação de feições caracteristicas na matriz dos solos, relevantes para classificação, co mo é o caso do horizonte argílico da classificação americana (ESTADOS UNIDOS, 1975) e do horizonte B textural da classificação brasileira (BENNEMA e CAMARGO, 1966). . 
Os componentes básicos da matriz do solo, o plasma, o vazio e o esqueleto estão sujeitos a alterações, in dividualmente ou em combinações, de acordo com o desenvolvi mento do intemperismo do solo indo originar as mais variadas características pedológicas. Destes compostos o plasma é o mais dinâmico, de maneira que constitui a fração coloidal do solo susceptivel de mobilização. Como o plasma é influenciado direta e indiretamente pelos processos de formação do solo, consequentemente, este pode designar a evolução do solo como um todo (DEMATTE et alii, 1977).

ESWARAN (1972) estudou uma sequência de solos, objetivando avaliar as propriedades micromorfológicas e suas alterações subsequentes com a evolução dos solos. Relatou que o horizonte câmbico dos Inceptissolos evi denciou um desenvolvimento mais intenso da fábrica do plasma, e esta característica distinguiu-os dos outros solos. A presença de iluviação de argilas, de papulas è uma tendência evidente para fábriça do plasma asepica, caracterizam os Ultissolos. A tendência da fábrica do plasma asepica para isotica com cores vermelhas escuras, redução nos vazios e ausência de lithorelictos foram as feições caracteristicas para oxissolos.

DEMATTE et alii. (1977) estudando feições micro morfológicas de uma topossequência de solos, constataram qué na maioria dos solos a fábrica do plasma é isotica ou endulica, evidenciando um grau avançado de intemperismo. A fábrica do plasma está relacionado principalmente ao tipo e conteúdo do mineral de argila, e com o grau de cristalinidade dos óxidos de ferro e aluminio. 
3. DESCRIÇÃO DA AREA DE ESTUDO

o planalto de Poços de Caldas está situado na borda ocidental da Serra da Mantiqueira e em contacto com os extremos orientais da bacia sedimentar do Paraná. Forma um conjunto morfo-estrutural considerado um domo, composto de ro chas efusivas e intrusivas, enquadrado nas latitudes de 46 e $470_{\mathrm{W}}$ (Greenwich) e nas latitudes de 21 e $22^{\circ} \mathrm{S}$ (Figura 1). Abran ge uma área de aproximadamente $800 \mathrm{~km}^{2}$, sendo ụma das maiores ocorrências de rochas alcalinas no Brasil. Sua forma é ligei ramente elítica, com o eixo maior de $35 \mathrm{~km}$, no sentido NE-SW e o menor com $30 \mathrm{~km}$, no sentido NW-SE. A altitude interna é de $1.300 \mathrm{~m}$, enquanto que, o anel circundante apresenta altitú des entre 1.500 a 1.700 metros

Foram escolhidas duas áreas testes no maciço al calino de Poços de Caldas, com a finalidade de estudar os solos desenvolvidos do material de alteração de rochas alcalinas, sendo uma localizada a oeste, a aproximadamente $27 \mathrm{~km}$ de Poços de Caldas e a outra ao sul a aproximadamente $10 \mathrm{~km}$ de An dradas (Figura 2). A escolha destas duas áreas teve o objetí vo de abranger, no estudo, solos com características morfoló- 


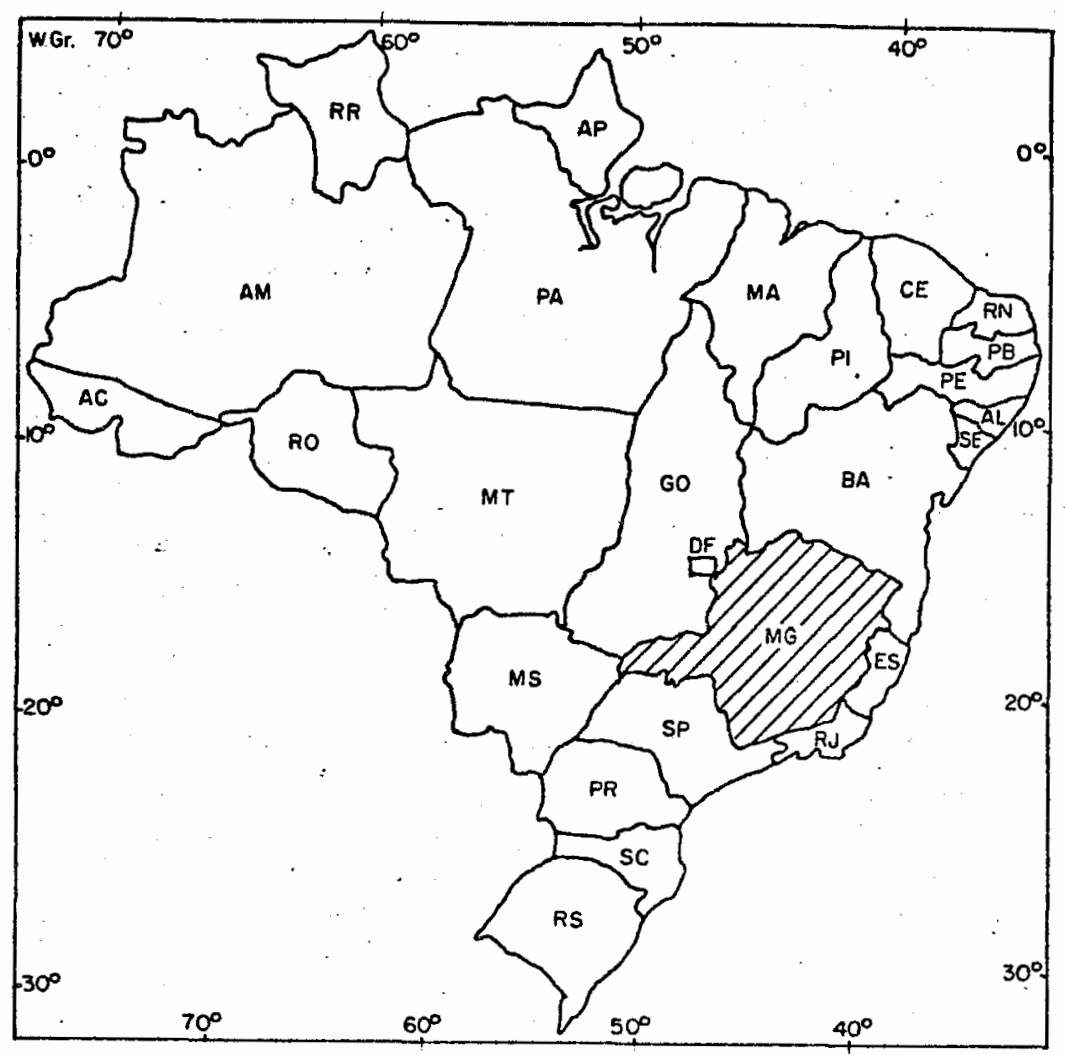

A

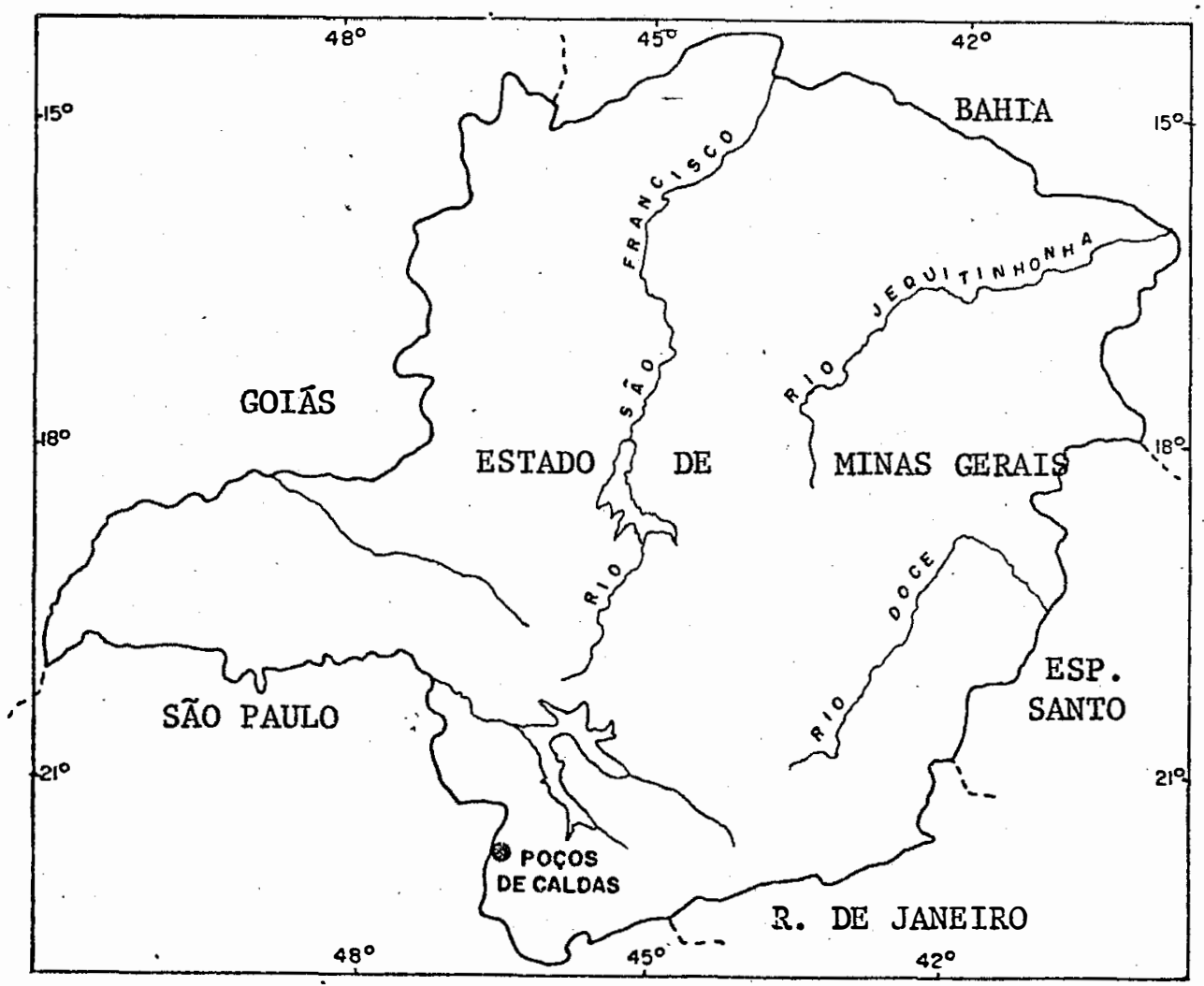

B

Figura 1 - Mapa de localização da área de estudo: A - em rela ção ao Brasil. B - Em relação ao Estado de Minas Gerais. 
gicas bem distintas existentes no maciço, e que não foi possí vel encontrá-los numa única área.

\subsection{Geologia}

O maciço alcalino de Poços de Caldas é constí tuído principalmente por rochas nefelina-tinguaitos e foiaitos, sendo que o interior do mesmo é ocupado por tufos, brechas, aglomerados e lavas ankaratriticas, todas anteriores à intrusão do dique anelar (ELLERT, 1959).

Segundo ELLERT (1959) as brechas são formadas por fragmentos angulosos de constituição gnaissica, arenítica, siltítica e quartzosa, fonolítica e tinguaitica, formando pacotes secundários sem variação litológica, apresentando duas origens: vulcânica e vulcânica com transporte posterior. As lavas ankaratríticas formam os aglomerados, de maneira que ro chas vulcânicas são encontradas em quase todo o bordo intemo, assentadas sobre sedimentos, ou intercaladas com tufos ou bre chas, dirigindo-se para o interior do maciço.

São encontrados derrames de lavas fonolíticas na parte sul do maciço, capeando sedimentos, podendo estar, ainda, perturbadas por intrusões posteriores de tinguaito. Es tão quase sempre alteradas e quando frescas têm cor castanho escuro. Encontra-se normalmente muito fraturada e quando alterada a cor é branco amarelada (ELLERT, 1959).

As rochas efusivas e hipoabissais estão representadas por tinguaitos e fonolitos, que ocupam a maior parte do maciço, apresentando textura afanítica, porfirítica, saca- 
róide ou granular e coloração verde escura. Os fonolitos apre sentam coloração escura, granulação fina a vitrea, enquanto que os tinguaitos uma granulação mais grosseira, constituida de aegerina, ortoclásio, leucita, pseudoleucita, nefelina e raramente augita, micropertita e apatita. Os minerais, acessórios são zircão, rutilo, magnetita, eucolita e eucialita, es fênio, ilmenita, pirita, quartzo, catapleita e lamprofilita e os secundários zeolitas, cancrinita ou natrolita e biotita (ELLERT, 1959; GORSKY e GORSKY, 1974).

As rochas plutônicas estão representadas pelos foiaitos, foiaitos traquitoides, lujauritos e chibinitos. Os foiaitos exibem uma textura granular grosseira, constituidos de anortoclásio, ortoclásio, micropertita, sanidina, plagioclásio, nefelina, aegerina, zircão, magnetita, ilmenita e apa tita, e são intrusivos nos tinguaitos ou representa uma sequência de transição entre os tinguaitos (ELLERT, 1959).

A frequência de minerais que compõem os fonoli tos e os tinguaitos apresentados por MONIZ (1969), é a seguin te: feldspatos alcalinos $(44,8 \% 0$; nefelina $(20,9 \%)$; piroxê nio sódico $(16,8 \%)$; zeolitas $(12,4 \%)$ e minerais de zircônio $(3,3 \%)$. Na Tabela 2 são apresentados os resultados de análises químicas de dois tipos de rochas alcalinas de poços de Caldas, pelos quais observa-se uma semelhança entre a composi ção do fonolito e do foiaito.

BARBOSA (1936) admitiu para o maciço de Poços de Caldas duas atividades do magma alcalino, sendo a primeira de natureza plutônica no pré-ordoviciano e a segunda vulcâa nica no fim do mesozóico. As rochas do maciço alcalino de Po ços de Caldas estariam compreendidas nos seguintes períodos: Triássico e Cretáceo (?) (Figura 2). 
Tabela 2 - Análise química de rochas alcalinas de Poços de Caldas MONIZ, 1969).

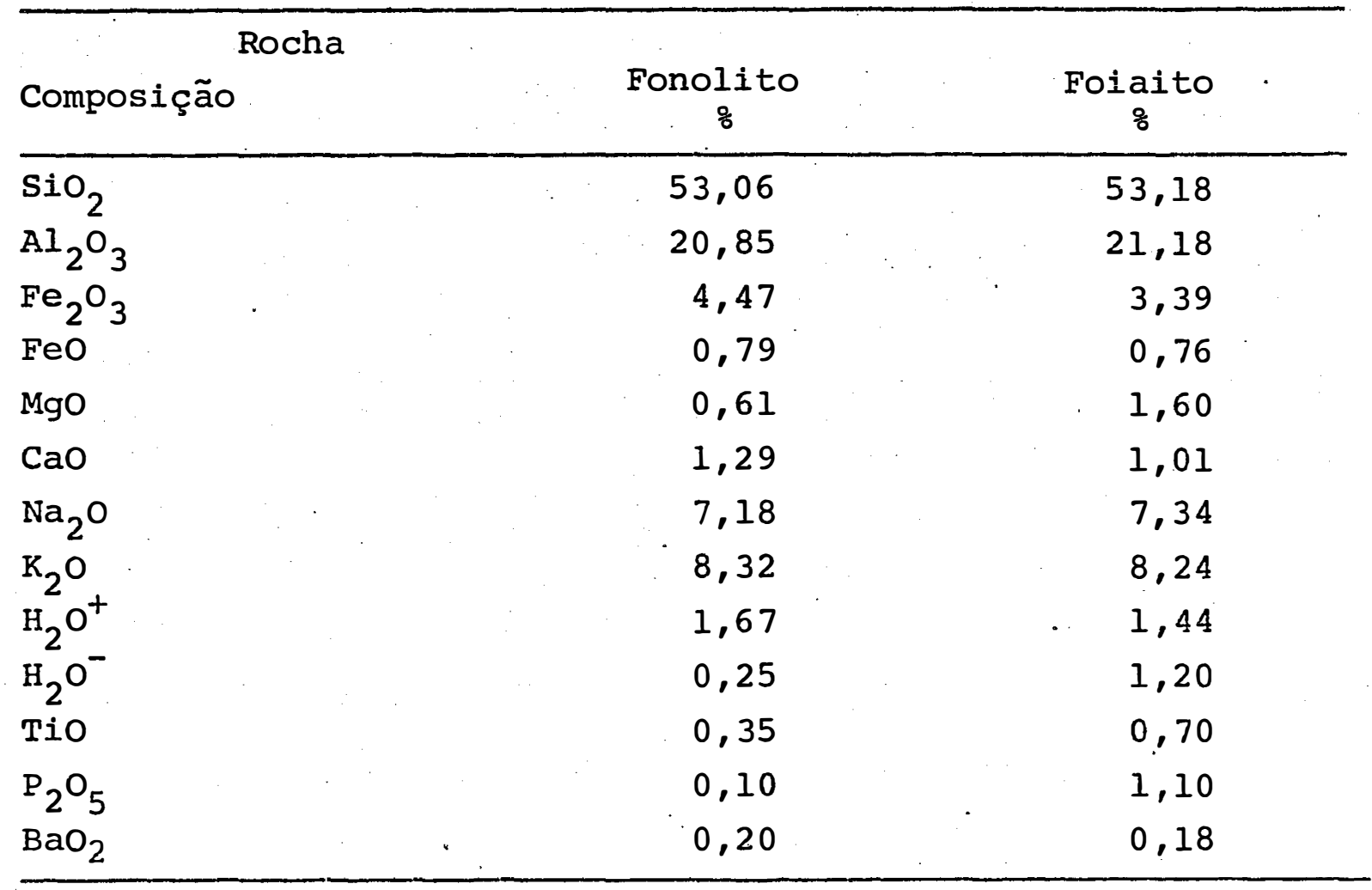

Os solos estudados no maciço alcalino de Poços de Caldas, foram desenvolvidos de material de alteração prove nientes de tinguaitos e fonolitos com presença de lentes de bostolitos na área $I$, e de lavas fonolíticas e foiaitos com lentes de anfibolitos na área II.

\subsection{Vegetação}

Na área do maciço alcalino de Poços de Caldas a cobertura vegetal está representada pela floresta subtropical subcaducifólia e pelos campos altimontanos. 
(i) 0จงอา7จ

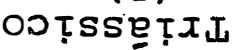
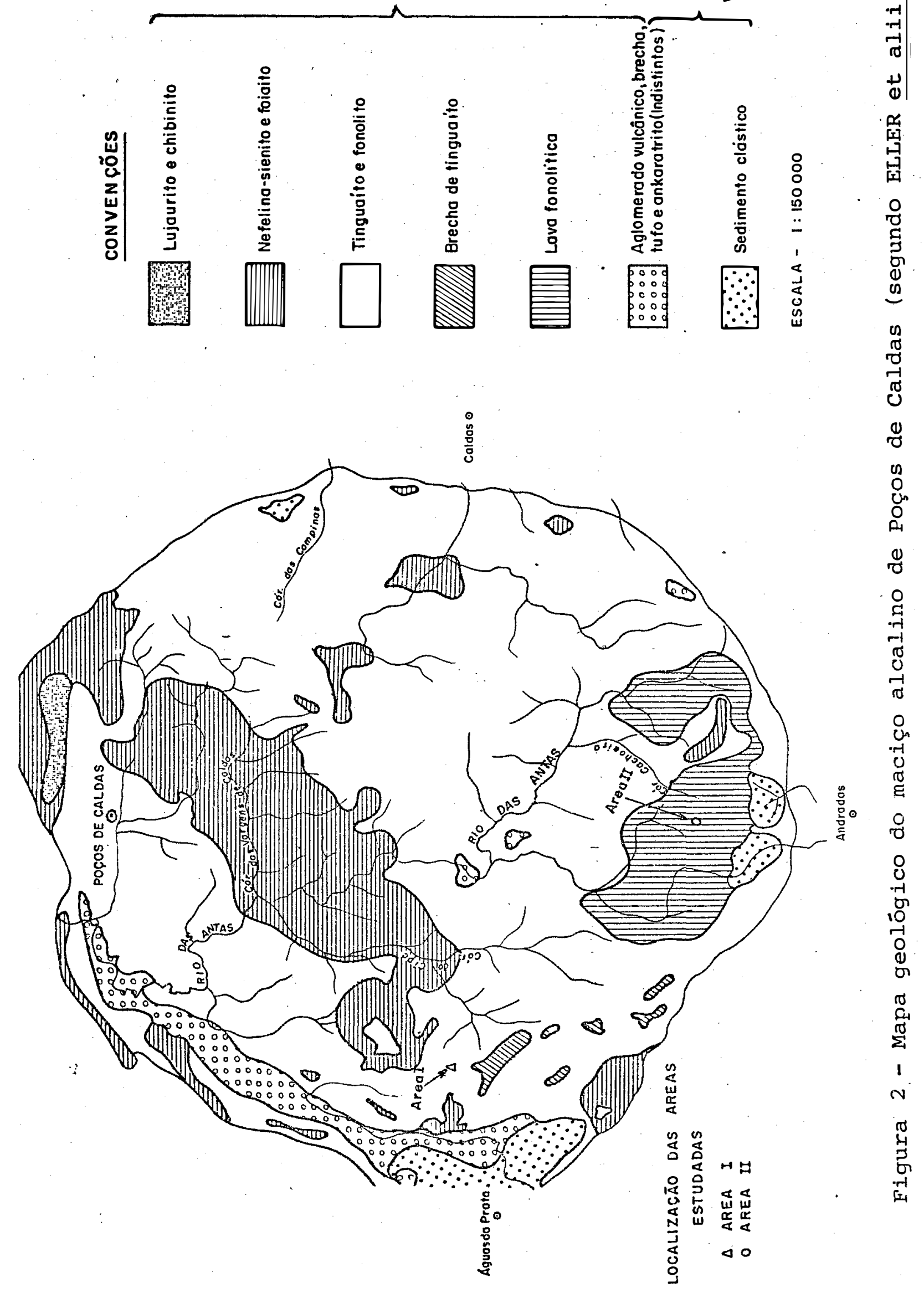
A floresta subtropical subcaducifólia caracteriza-se pela presença de plantas decíduas, que perdem as folhas durante a estação seca.

A existência dessa floresta está ligada não somente ao clima mais ameno, mas, também a solos mais férteis, como os derivados de tufos vulcânicos. Apresenta três estratos, sendo um superior em torno de 20 a 30 metros de altura, de modo que quase todos os elementos perdem as folhas durante a estação seca: o segundo é constituído por espécies de 5 a 15 metros de altura e de folhas perenes e pouco denso e o extrato inferior arbustivo, com elementos alcançando cerca de 2 metros de altura (ALONSO, 1977).

A origem local desta floresta parece estar ligada às oscilações climáticas preteritas, quando a floresta do Brasil meridional avançava e recuava, restando manchas como formas relequias. (ALONSO, 1977).

Dentre as espécies características encortra das nessa floresta segundo AZEVEDO (1.962), citam-se as seguin tes, dispostas nos três estratos: Araucaria angustifolia (pinheiro), Podocarpus sellowii (pinheirinho), Nectandra sp. (ca nela amarela), Ocotea sp. (canela branca), Berberis lauruia, Schinus sp., Dicksonia sellowiana, Miconia sp., Cyperus sp., cladium sp., Barreria bradei, etc.

Os campos altimontanos caracterizam-se por uma cobertura herbácea, muitas vezes continua, no interior da qual pode aparecer arbustos isolados. Ocorre em altitudes acima de 1000 metros, razão pela qual são comumente denomina dos de "campos de àltitude". 
Os campos do maciço alcalino de Poços de Caldas são encontrados em altitudes superiores a 1.600 metros so bre solos "sílico-argilosos" em clima caracterizado por tem peraturas moderadamente baixas e chuvas distribuidas num perio do chuvoso de outubro a março e outro seco de abril a setem bro (AZEVEDO, 1962). Dentre as espécies caracteristicas podem ser citadas as seguintes: Cladium eusifolium, Aristida sp., Paepalanthus polyanthus, Habernavia sp., Miconia sp. e Microlicia isophylla.

Segundo CHRISTOFOLETTI (1970), as condições cli máticas atuais não são propícias para explicar o tipo de vege tação que ocorre no planalto de poços de Caldas, tendo em vista se rem adequadas para a existência generalizada de florestas. Em relação as diferenças na composição mineralógica das rochas , MONIZ (1969) observou que os tinguaitos, fonolitos e foiaitos apresentam composição semelhante e, a vegetação campo-matas. ocorrem sobre afloramentos continuos da mesma rocha. As variações paleoclimāticcas seriam a causa mais provável para a existência desse tipo florístico.

A existência dessas oscilações podem ser basea das no seguinte: a) presença de pavimentos detríticos constí tuỉdos por concreções, recobrindo as vertentes atuais em diversos locais. O recobrimento concrecionário não apresenta gênese atual, sendo antigo, devido ser encontrado em várias partes soterrado por camadas argilosas coluviais, sem que 0 paleopavimento perca continuidade entre a parte que se estende pela superfície e a parte soterrada. A gênese e a exposição superficial dessas concreções evidenciam variações climáticas; b) a formação de bauxitos, a partir da transformação direta das rochas alcalinas e não de argilas provenientes da meteorização, também pode evidenciar oscilação paleoclimática (CHRISTOFOLETTI, 1970). 
A vegetação da área do maciço alcalino de Poços de Caldas reflete as alterações decorrentes das condiçc̃es de clima, solos, altitude, relevo e duração da estação seca. A cobertura vegetal atualmente predominante nas duas áreas é representada por vegetação típica de cerrado e campo cerrado.

\subsection{Clima}

o clima do maciço alcalino de poços de Caldas é do tipo mesotérmico brando subúmido que se caracteriza por um clima com predomínio de temperaturas amenas durante todo o ano com média anual em torno de $18^{\circ} \mathrm{C}$, devido principalmente à fisiografia da área (NIMER, 1977).

O verão é ameno com o mês mais quente apresentando temperatura média inferior a $22^{\circ} \mathrm{C}$, com predomínio de temperaturas médias entre $18^{\circ} \mathrm{C}$ e $20^{\circ} \mathrm{C}$. O inverno é bastante sensível e tem pelo. menos um mês com temperatura média inferior a $15^{\circ} \mathrm{C}$, porém, nunca inferior a $10^{\circ} \mathrm{C}$. Os meses mais frios são junho e julho, sendo comuns mínimas diárias próximo de $0^{\circ} \mathrm{C}$, advindo daí que a média das mínimas nesses meses seja de $12,9^{\circ} \mathrm{C}$. A temperatura mínima absoluta é de $4,6^{\circ} \mathrm{C}$ abaixo de zero. O fenômeno de geada é bastante comum, com períodos variáveis de 5 a 20 dias durante o ano (NIMER, 1977).

A precipitação pluviométrica média anual é de $1.745 \mathrm{~mm}$, com um período chuvoso compreendido entre os meses de outubro a março e o período menos chuvoso de abril a setem bro, com estação seca de dois meses, compreendendo julho e agosto.

Conșiderando os regimes de umidade e térmico dos solos do maciço alcalino de poços de Caldas seṛiam údicos è isotérmicos (ESTADOS UNIDOS, 1975; OLIVEIRA. et alii, 1976). 
Como nas áreas tropicais e subtropicais considera-sè em geral que a formação do solo se dá em termos cíclí cos (DE VILLIERS, 1965), por serem encontrados em superfícies antigas, climas preteritos devem ter influido na gênese dos mesmos. Considerações genēricas sobre flutuações climāticas no quaternário para esta região foram feitas por CHRISTOFOLET. TI (1970).

\subsection{Geomorfologia (relevo)}

O maciço alcalino de Poços de Caldas está encravado no planalto sul de Minas, que apresenta-se com uma su cessão de morros e garupas, entre 1000 e 1100 metros de al titude, cuja continuidade é interrompida por uma série · de cristas que formam a superfície de 1600 metros; as cristas apresentam-se adaptadas às orientações gerais dos gnaisses as semelhando-se às cristas tipo apalacheano (MOREIRA e CAMELIER, 1977). O maciço alcalino de Poços de Caldas ergue-se de 1500 a 1700 metros de altitude, sendo considerado um "domo formado por rochas eruptivas". As rochas nefelinas de Poços de Caldas, são talvez, posterior ao derrame basáltico do sul do Brasil. Apesar de apresentarem grã grossa, com provável origem plutônicas, mas o aparecimento de rochas de grã fina, com prova a existência de erupções vulcânicas mais recentes. Sendo o vulcanismo, desse modo, considerado contemporâneo das fa lhas do.Brasil sudeste (MOREIRA e CAMELIER, 1977).

Morfologicamente, o maciço de Poços de Caldas apresenta-se como uma unidade individualizada, sendo delimita da, por um dique anelar quase completo, em função da intrusão do magma nefelino na periferia do maciço ao longo de fendas circulares (ELLERT, 1959; CHRISTOFOLETTI, 1970). A topografia do dique anelar é bastante expressiva em três quadrantes: norte, oeste e sul; enquanto que no leste não se observa expressão morfológica do anel de tinguaito. 
O maciço alcalino apresenta duas áreas geomorfo logicamente distintas: uma com topografia movimentada em sua parte oriental, drenada pelo rio das Antas, onde são encontrados níveis mais elevados, em torno de 1400 metros; caracteriza-se por uma movimentação intensa de relevo, com vertentes que normalmente atingem declividades superiores a $20^{\circ}$; a drenagem apesar de condicionada por linhas tectônicas, apresenta vales encaixados, com rupturas de declives e presença de várzeas estreitas e pouco alongadas. A outra parte do maciço caracteriza-se por topografia menos movimentada, com vales de vertentes mais suaves e presença mais constantes de topos aplai nados (ELLERT, 1959 e CHRISTOFOLETTI, 1970).

As características geomorfológicas das duas áreas onde foram estudados os solos no maciço alcalino de poços de Caldas, estão representadas por morros de baixa resis tência à erosão, com topos arredondados e encostas côncava-con vexa; os vales são abertos; com drenagem de densidade média e declividade suave:

As superfícies das duas áreas correspondem a pe dimentos (pediplano) com níveis topográficos distintos que podem ser atribuidos a ação de fases de erosão diferentes, admitindo-se uma formação policíclica. A superfície da área II apresenta níveis topográficos mais expressivos que a superfí cie da área I (Figura 4). PENTEADO (1983) atribui que as causas do desenvolvimento do relevo policíclico se prendem a modi ficações do nível de base ou a retomadas erosivas de origem climática. Nestas áreas, seria melhor atribuido às retomadas erosivas de origem climática para a presença de relevo policíclico na área.

A presença de paleossolos (solos enterrados) e linha de concreções lateríticas e bauxíticas, nestas superfí - 


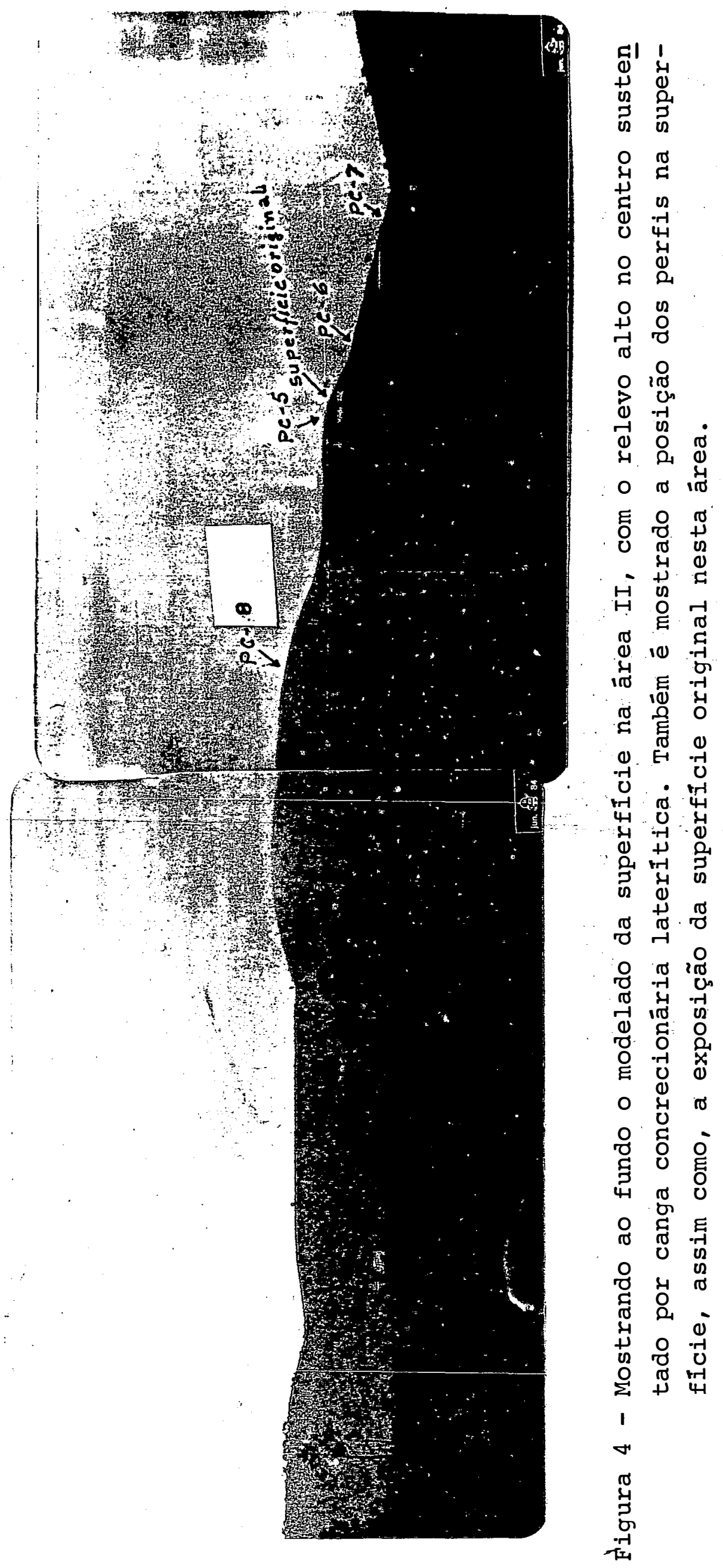

37. 
cies, são indícios que indicam ocorrência de fases alternadas de erosão e agradação na formação do solo (BUTLER, 1959 e PEN TEADO, 1983). Estes fatos podem ser considerados como evidências de ação de paleoprocessos na construção das superfícies (paisa gens) atuais, ocorrentes na área de estudo.

Segundo RUHE (1956) a linha de pedras nos solos originaria-se durante os processos de erosão e deposição, através dos quais ocorrem a evolução da paisagem, de maneira que os fragmentos mais grosseiros (rochas) seriam concentra dos pela remoção de materiais mais finos.

OJANUGA e WIRTH (1977) consideram a importân cia da origem multicíclica das paisagens, de modo que a erosão ocorreria durante o período de instabilidade (OLLIVIER , 1959) e deveria ter-se alterado repetidamente no passado com a pedogênese ocorrendo no período de estabilidade.

Para BUTLER (1959) a ocorrência de soios enter rados seria uma evidência de que o desenvolvimento do solo $e$ a erosão teriam ocorridos mais em fases, do que em processo contínuo. De maneira que, a ịdéia fundamental seria o solo cíclico, compreendendo a alternância de uma fase de instabili dade, quando as superficies de solos mais velhos seriam destruídos ou enterrados, e uma fase de estabilidade, quando ocor reria o desenvolvimento dos solos nas novas superficies. 


\subsection{Solos}

Na região de Poços de Caldas os solos predomi nantes assemelham-'se morfologicamente a solos já identificados no sul do Brasil, como os Latossolos Brunos e as Terras Brunas Estruturadas. Caracterizam-se por apresentarem perfis relati vamente profundos, de drenagem moderada a boa, de coloração brunada ou mesmo avermelhada, com estrutura no horizonte $B$, bem desenvolvida em forma de blocos suabgulares em grau moderado a fraco. A estrutura toma aspecto mais evidente nos cor tes velhos de estradas onde o processo de umedecimento e seca mento é mais ativo e frequente.

As principais características destes. solos são a coloração brunada e o desenvolvimento de estrutura. o aspec to da estrutura faz lembrar a Terra Roxa Estruturada caracterizada em diversas regiões brasileiras. Diferem destas no que se refere as caracteristicas de cor. Enquanto que, as Terras Roxas Estruturadas possuem cores nos matizes em torno de 2,5YR a 10R, os solos desta região apresentam cores no horizonte $B$, com matizes variäveis de 5 YR a l0YR, sendo mais comum no matiz 7,5YR. Devido a este aspecto, têm sido classificados como Terras Brunas Estruturadas (EMBRAPA, 1980 a e b e 1982). Quanto ao Latossolo Bruno, apresenta características latossólicas e predominância das cores brunadas. 


\section{MATERIAL E METODOS}

\subsection{Material}

o material que serviu de base para este estudo constou da coleta de sete perfis de solos em duas áreas no ma ciço alcalino de poços de Caldas. Na área I foram coletados quatro perfis ( $\mathrm{PC}-1, \mathrm{PC}-2, \mathrm{PC}-3$ e $\mathrm{PC}-4$ ) de solos desenvolvi dos de material proveniente da alteração de tinguaitos e fono litos com lentes de bostolitos. Na ārea II foram coletados três perfis (PC-5, PC-6 e PC-7) de solos desenvolvidos de material de partida resultante da alteração de lavas fonoliticas e foiaitos com lentes de anfibolitos. Posteriormente, foi coletado mais um perfil complementar, na área II, designadoco mo PC-8, com a finalidade de auxiliar na caracterização dos solos e na elucidação da presença de paleossolos nestas áreas.

\subsection{Métodos}

As amostras dos solos foram secas ao ar, destor roadas e passadas em peneiras com malhas de abertura de $2 \mathrm{~mm}$. A fração menor que $2 \mathrm{~mm}$ constitui a terra fina seca ao ar (TFSA), na qual foram efetuadas as análises físicas, químicas e mineralógicas, enquanto que, nas amostras do perfil PC-8, foram realizadas somente análises físicas e químicas referen tes à levantamento de solos. 


\subsubsection{Análises físicas}

Análise mecânica - As análises físicas constan do de análise granulométrica, argila dispersa em água e equivalente de umidade, foram realizadas no laboratório de solos do Serviço Nacional de Levantamento e Conservação de Solos SNLCS-EMBRAPA, segundo os métodos inseridos no Manual de Méto dos de Análises de Solos (EMBRAPA, 1979).

Curva de retenção de água - As curvas de reten ção de água foram determinadas através do conteúdo de água re tida em amostras de solos deformadas, (terra fina < $2 \mathrm{~mm}$ ) colo cadas em anéis de borracha e submetidas as tensões de 0,10; 0,33; 0,50; 1,00; 5,00 e 15,00 atmosferas, usando aparelho de placa de pressão conforme procedimento descrito por RICHARDS (1954). A água disponível foi estimada pela diferença no con teúdo de água entre as tensões de 0,33 e 15 atmosferas.

Densidade aparente - A densịdade aparente (glo bal) foi determinada em amostras indeformadas coletadas com anel volumétrico de $50 \mathrm{~cm}^{3}$. Foram feitas duas amostragens por horizonte e colocadas em latas de aluminio numeradas e de peso conhecido, procedendo-se em seguida conforme a metodologia re comendada pelo Manual de Métodos de Análises de Solos (EMBRAPA, 1979).

Superfície específica - A superfície específi ca das amostras foi obtida pelo uso de etileno glicol monoe til eter (EGME), seọundo CARTER et alii (1965); HEILMAN et alii (1965) e CIHAEK e BRENMER (1979). As amostras de solo (< $2 \mathrm{~mm}$ ) foram moidas e passadas em peneiras de 60 "meshs". Foram feitas pesagens de aproximadamente $0,60 \mathrm{~g}$ e colocadas em dessecador com $\mathrm{P}_{2} \mathrm{O}_{5}$ anidro, até a obtenção de peso constan 
te. Nas amostras ao atingirem um peso constante, foram adi cionados 1,2 ml de EGME, colocadas em dessecador com $\mathrm{CaCl}_{2}$ anidro e submetidas a vácuo, fazendo-se pesagens em interva los pré-determinados até atingirem peso constante. A superfície especifica total foi calculada pela fórmula:

$$
\mathrm{SE}=\frac{\mathrm{g} \text { EGME }}{\mathrm{g} \text { (amostra) } \times 2,86 \times 10^{-4} \mathrm{~g} / \mathrm{m}^{2}}
$$

\subsubsection{Análises químicas}

As análises químicas referentes a carbono orgâ nico, nitrogênio total, $\mathrm{pH}$ em $\mathrm{H}_{2} \mathrm{O}$ e $\mathrm{KCl}$; fósforo assimilável, cálcio, magnēsio, potássio, sōdio e aluminnio trocáveis, aci dez trocável $\left(\mathrm{H}^{+}+\mathrm{Al}^{+++}\right)$, ataque sulfúrico $\left(\mathrm{H}_{2} \mathrm{SO}_{4} 1: 1+0,8 \%\right.$ de $\mathrm{NaOH})$ e determinações de $\mathrm{SiO}_{2}, \mathrm{Al}_{2} \mathrm{O}_{3} \mathrm{Fe}_{2} \mathrm{O}_{3}, \mathrm{TiO}_{2}$ e $\mathrm{MnO}, \mathrm{Ca} \underline{1}$ culo dos valores de soma de bases $(S)$, capacidade de troca de cátions $(T)$, saturação de bases $(V \%)$, saturação com aluminio $\left(100 \mathrm{Al}^{+++} / \mathrm{Al}^{+++}+\mathrm{S}\right)$ e, das relações moleculares: $\mathrm{SiO}_{2} / \mathrm{Al}_{2} \mathrm{O}_{3}$ (Ki): $\mathrm{SiO}_{2} / \mathrm{Al}_{2} \mathrm{O}_{3}+\mathrm{Fe}_{2} \mathrm{O}_{3}(\mathrm{Kr})$ e $\mathrm{Al}_{2} \mathrm{O}_{3} / \mathrm{Fe}_{2} \mathrm{O}_{3}$, foram realizadas no laboratório de solos do Serviço Nacional de Levantamento e Conservação de Solos, segundo os métodos inseridos no Manual de Métodos de Análises de Solo.s (EMBRAPA, 1979).

Fracionamento de humus - o carbono orgânico to tal foi determinado por oxidação sulfocrômica em meio sulfúrí co. O fracionamento do humus foi realizado na fração terra fina (< $2 \mathrm{~mm}$ ) segundo a metodologia de DABIN (1971), pelo laboratório de solos do. Centro de Energia Nuclear na Agricultuda - CENA/USP.

Càrgas elétricas - As cargas elétricas positivas, negativas e líquidas dos solos foram determinadas por um 
método similar ao descrito por SCHOFFIELD (1949). Foram pesa das amostras de terra fina $(<2 \mathrm{~mm}$ ) equivalente a $2 \mathrm{~g}$ de TFSE e colocadas em tubos de centrífuga previamente pesados, adicionando-se em seguida $30 \mathrm{ml}$ de $\mathrm{KCl} \mathrm{N}$. As amostras foram agitadas por um minuto na mão e centrifugadas e o líquido sobrenadante descartado. Este processo de saturação foi repetido três vezes. As amostras foram lavadas em seguida mais. três vezes com $\mathrm{KCl} 0,1 \mathrm{~N}$, utilizando-se do mesmo procedimento. Antes de descartar o sobrenadante da última lavagem com KCl 0,1 $\mathrm{N}$, foi determinado $\circ \mathrm{pH}$ da solução. Depois de descartado o sobrenadante líquido final, as amostras foram pesadas para de terminar a quantidade de $\mathrm{K}$ e $\mathrm{Cl}$ ocluso. O $\mathrm{K}$ e $\mathrm{Cl}$ saturante foram então removidos com três lavagens de $30 \mathrm{ml}$ de $\mathrm{Ca}\left(\mathrm{NO}_{3}\right)_{2}$ $0,1 \mathrm{~N}$ e retidas para determinação de $\mathrm{K}$ e $\mathrm{Cl}$. O potássio foi determinado em fotômetro de chama e o cloro com tiossulfato férrico em espectrômetro VARIAN, segundo metodologia de RUZIC $\mathrm{KA}$ et alii (1976).

PCZ e carga líquida de superfície - O PCZ e a carga líquida de superfície foram determinados nas amostras por titulação $\mathrm{com} \mathrm{H}^{+}$e $\mathrm{OH}^{-}$em três concentrações eletrolíti cas de $\mathrm{KCl}$, seguindo procedimento delineado por VAN RAIJ e PEECH (1972), GILLMAN e UEHARA. (1980) e UEHARA e GILLMAN (1981). As amostras foram lavadas três vezes com $\mathrm{KCl} N \mathrm{~N}$ para elimina ção de cátions e ânions trocáveis. Em seguịda foram lavadas com água destilada até que a concentração eletrolítica fosse reduzida a um valor baixo $(<0,002 \mathrm{M})$.

Óxidos de ferro livre - Os óxidos de ferro li vres foram removidos das amostras de solos (<2 mm) e da fra ção argila pelo método do citrato-bicarbonato-ditionito de sō dio (CBD) segundo o procedimento de MEHRA e JACKSON (1960) e JACKSON (1969). O ferro foi determinado pelo método colori métrico com ortofenantrolina de acordo com o procedimento de 
KRISHMA MURTI et alii (1966). O alumínio extraído pelo citra tó-bicarbonato-ditionito de sódio foi determinado pelo método colorimétrico com aluminon, de acordo com HSU (1963) e JACKSON (1969), que compreende a digestão de uma alíquota do extrato do $\mathrm{CBD}$ com $\mathrm{H}_{2} \mathrm{O}_{2}$ e separação de $\mathrm{Al}$ do $\mathrm{Fe}$ com $\mathrm{NaOH}$, antes da determinação do Al (JACKSON, 1969). O manganês do extrato do CBD foi determinado por absorção atômica.

Oxidos de $\mathrm{Fe}$, Al e Mn amorfos - Os óxidos de ferro, alumínio e manganês amorfos foram extraídos das amostras de solos $(<2 \mathrm{~mm})$ e da fração argila com oxalato de amônio 0,2 M a pH 3,0, com período de agitação de 4 horas no escuro, segundo procedimento de McKEAGUE e DAY (1966). A determinação do ferro e alumínio foram realizados por métodos colo rimétricos com ortofenantrolina (KRISHMA MURTI et alii, 1966 e JACKSON, 1969) e aluminon (HSU, 1963 e JACKSON, 1969)., respectivamente, após o tratamento do extrato com $\mathrm{KNO}_{3}$ e $\mathrm{H}_{2} \mathrm{SO}_{4}$ e aquecimento a $450^{\circ} \mathrm{C}$ por duas horas (WEAVER et alii, 1968). O manganês extraído pelo oxalato foi determinado por absorção atômica.

\subsubsection{Análises mineralógicas}

As análises mineralógicas furam efetuadas em amostras de horizontes selecionados dos perfis de solos, como segue: $A u, B w 1, B C$ e $C 2$; $A u p, B w 1, B C$ e C2; Aup, $B C, B w 2, B w 3$, $B C$ e $C 2$ e Aup, Bw1, Bw2, Bw3 e Bwb, correspondentes aos perfis $\mathrm{PC}-1, \mathrm{PC}-2, \mathrm{PC}-3$ e $\mathrm{PC}-4$ da área $\mathrm{I}$, respectivamente $\mathrm{e}$ as referentes aos horizontes $\mathrm{Aec}, \mathrm{BA}, \mathrm{Cl}$ e $\mathrm{C} 2$; $\mathrm{Au}, \mathrm{BA}$ e $\mathrm{BC}$ e $\mathrm{Au}$, $\mathrm{Bw} 1, \mathrm{Bw} 3, \mathrm{Aub}$ e Bwb, dos perfis $\mathrm{PC}-5, \mathrm{PC}-6$ e $\mathrm{PC}-7$ da ărea II, respectivamente. 
Pré-tratamento - o prē-tratamento das amostras para análise mineralógica, consistindo da remoção da matéria orgânica e óxidos livres de manganês, foi realizado somente nos dois primeiros horizontes selecionados de cada perfil, uti zando-se água oxigenada $\left(\mathrm{H}_{2} \mathrm{O}_{2}\right.$ a $\left.30 \%\right)$, segundo procedimento de JACKSON (1969). Os óxidos de ferro livres foram removidos de todas as amostras selecionadas pelo método do citrato-bicarbonato-ditionito (CBD), segundo MEHRA e JACKSON (1960) e JACKSON (1969).

\section{Fracionamento - o fracionamento das amostras} após a remoção da matéria orgânica e dos óxidos de ferro livres foi realizado por peneiragem úmida, centrifugação e decan tação, segundo procedimento de JACKSON (1969), sendo separadas as seguintes frações: areia, $(200-50 \mu)$, silte $(50-2 \mu)$ e argila $(<2$

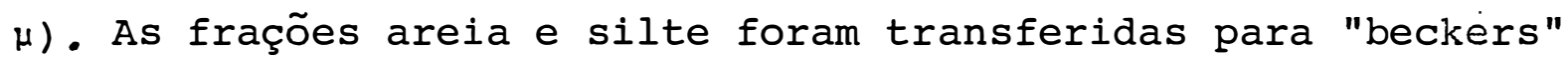
previamente pesados e postas em estufa a $110^{\circ} \mathrm{C}$ para secar. A fração argila foi reservada em recipiente na forma de suspen são.

Saturação de amostras - Amostras da fração argila foram saturadas com potássio (K) e magnésio (Mg), segundo metodologia de JACKSON (1969).

Análise quantitativa - A caulinita e a gibbsita da fração argila foram estimadas quantitativamente por análise termo diferencial (DTA) através de procedimento similar ao descrito por DIXON (1966) e modificado por MONIZ e JACKSON (1967). Amostras da fração argila saturadas com magnésio (Mg) e secas a $110^{\circ} \mathrm{C}$, foram diluidas com $\mathrm{Al}_{2} \mathrm{O}_{3}$ previamente calcinado a $950^{\circ} \mathrm{C}$, tendo em vistas os altos teores de caulinita e alguns de gibbsita. As curvas padrões foram obtidas de caulinita e gibbsita puras diluidas com $\mathrm{Al}_{2} \mathrm{O}_{3}$, para obtenção dos di- 
versos padrões. As amostras da fração argila e os padrões fo ram misturados num almofariz de āgata com $\mathrm{Al}_{2} \mathrm{O}_{3}$ para obtenção de uma mistura homogênea. As amostras e os padrões foram colocados em cadinhos e aquecidos em aparelho de análise termo diferencial (DTA) marca RIGAKU, na taxa de $10^{\circ} \mathrm{C} / \mathrm{minuto}$ e velo cidade do papel no registrados de $20 \mathrm{~cm} / \mathrm{h}$. As percentagens de caulinita e gibbsita foram obtidas pela fórmula:

$\%$ mineral na argila $=\frac{\% \text { mineral pela curva padrão } \times 100}{\% \text { argila na mistura com } \mathrm{Al}_{2} \mathrm{O}_{3}}$

Os materiais amorfos foram determinados por análises de dissolução seletiva com $\mathrm{KOH} 0,5 \mathrm{~N}$ fervente, pelo método de ALEXIADES e JACKSON (1966), JACKSON (1969) e EL-ATTAR et alii (1969). O silício e o alumínio extraído foram determinados pelo método colorimétrico do molibdato de amônio amarelo e pelo aluminon, respectivamente (JACKSON, 1969). O ferro extraído pelo CBD foi determinado em colorímetro com or tofenantrolina (JACKSON, 1969). O conteúdo de $\mathrm{Al}_{2} \mathrm{O}_{3}$ equiva lente à percentagem de gibbsita determinada por DTA, foi sub traída do conteúdo de $\mathrm{Al}_{2} \mathrm{O}_{3}$ obtido pela anälise de dissolução seletiva. O restante do $\mathrm{Al}_{2} \mathrm{O}_{3}$ foi combinado com o silício $\left(\mathrm{SiO}_{2}\right)$ dissolvido pela análise de dissolução seletiva para oḅ. tenção da percentagem de material amorfos (alofanas) (JACKSON, 1969 e EL-ATTAR et alii; 1969).

A mica foi determinada com base no teor total de $\mathrm{K}_{2} \mathrm{O}$, após o tratamento da amostra com $\mathrm{HF}$ e $\mathrm{HClO}_{4}$, a quente, segundo procedimento de PRATT (1965) e ALEXIADES e JACKSON (1966). A percentagem de mica na fração argila foi obtida pressupondo-se que a mica contenha $10 \%$ de $\mathrm{K}_{2} \mathrm{O}$ (JACKSON,1969), de maneira que $1 \%$ de $\mathrm{K}_{2} \mathrm{O}$ na amostra corresponde a $10 \%$ de mi ca. 
Análise qualitativa - Para as análises minera lógicas por difratometria de raios-X, utilizou-se um aparelho RIGAKU equipado com tubo de $\mathrm{Cu}$ e filtro de $\mathrm{Ni}$, operando com $20 \mathrm{~m} \mathrm{~A}$ e $40 \mathrm{Kw}$; para o que, foram preparadas lâminas orientadas da fração argila previamente saturadas com $\mathrm{K}$ e Mg. Consistiu na utilização de pequena porção de pasta de argila șatú rada, a qual foi distribuida sobre uma lâmina de vidro com auxí lio de espátula ou outra lâmina de vidro em fina camada, para orientação dos planos basais dos argilo-minerais (THIESEN e HARWARD, 1962). Foram analisadas as amostras. saturadas com $\mathrm{K}$ a $25^{\circ} \mathrm{C}$ e as calcinadas a $350^{\circ} \mathrm{C}$ e $550^{\circ} \mathrm{C}$ por duas horas, e, as saturadas com Mg, ao natural e glicoladas, no intervalo de 3 a $40^{\circ} \theta$. As frações areia e silte foram moidas e analisadas pelo método de pó em suporte de alumínio, no intervalo de 3 a $60^{\circ} 2 \theta$.

A interpretação dos difratogramas de raios-X foi realizada utilizando-se as normas adotadas por BROWN (1961), GRIM (1968) e JACKSON (1969). Para a análise semiquan titativa dos componentes mineralógicos das frações silte e areia, foram medidas as áreas dos picos nos difratogramas de raios-X e comparadas com as cbtidas das amostras padrões.

Formas cristalinas de óxidos de ferro - Para identificação das formas cristalinas dos óxidos de ferro, as amostras da fração argila com ferro, foram tratadas com $\mathrm{NaOH}$ $5 \mathrm{~N}$ fervente, seguindo o procedimento de NORRISH e TAYLOR (1961) modificado por KAMPF e SCHWERTMANN (1982). Após este trata mento as amostras foram analisadas pelo método de pó em supor te de alumínio, no intervalo de 3 a $60^{\circ} 2 \theta$ em aparelho de raio-X RIGAKU equipado com tubo de cobre e filtro de níquel. A interpretação dos difratogramas foi realizada de acordo com SCHERTMANN e TAYLOR (1977). 


\subsubsection{Análise micromorfológica}

Foram coletadas amostras de solos indeformadas para cada horizonte, observando-se a orientação no perfil de solo. No laboratório as amostras foram modeladas como cilindros, adaptando-as em copos de vidros e postas a secar ao ar. Antes de ser processada a impregnação, as amostras foram submetidas a secagem em estufa a 60 a $70^{\circ} \mathrm{C}$ pelo período de 4 horas.

A impregnação das amostras foi realizada seguindo um procedimento similar ao descrito por BUOL e FADNESS (1961) e MENDES et alii (1973), utilizando-se uma mistura em partes iguais de resina (resina polilyte T208) e diluente (mo nômero de estireno), com adição de 4 gotas de catalizador (pe róxido de metil-etil-cetona) como endurecedor, para cada 100 ml da mistura. Esta mistura foi colocada em funil separador adaptado a um dessecador. As amostras são colocadas no dessecador, fechadas todas as válvulas e submetidas a vácuo equi valente a uma pressão de 7 a $8 \mathrm{~mm}$ Hg pelo período de 5 a 10 minutos para eliminação do ar no sistema. A sèguir, à mistura foi adicionada vagarosamente às amostras até cobrí-las, com solução suficiente para inundá-las. Após o final da impregna ção as amostras foram evacuadas, por um período adicional de 30 a 45 minutos, sendo então retiradas do dessecador e colocadas para endurecer em temperatura ambiente. o período de endurecimento foi de 5 a 10 dias.

As seções delgadas foram obtidas, pelos méto -. dos usuais empregados em petrologia (CADY, 1965.).

As lâminas foram examinadas em microscópio petrográfico e descritas de acordo com a terminologia de BREWER (1976). 


\subsubsection{Classificação}

Para classificação natural dos solos adotou-se - Sistema Brasileiro de Classificação de Solos proposto por BENNEMA e CAMARGO (1964) com modificações introduzidas pelo Serviço Nacional de Levantamento e Conservação de Solos e o sistema compreensivo americano - Soil Taxonomy (ESTADOS UNI- DOS, 1975). 
A apresentação dos resultados è discussão será feita inicialmente levando-se em consideração as propriedades dos solos em separado, ou seja, propriedades morfológicas, fí sicas, químicas e mineralógicas, incluindo aqui também a micromorfologia. Como complementação deste capîtulo é apresentado um tópico abrangente, levando-se em consideração todas as propriedades estudadas relacionando os aspectos da pedogênese. No final é apresentado sugestões de classificação dos solos estudados em dois sistemas de classificação, brasileiro e americano.

Todo o eștudo foi realizado em duas sequências de solos, designado como ārea I e área II que são geomorfologicamente semelhantes. Devido a este fato a apresentação dos resultados e discussão será feita conjuntamente, não fazendose distinção entre elas. Os solos da área I tem sido cultiva dos mais intensamente do que os da área II, recebendo inclusi ve calagem periódica. 


\subsection{Morfologia e distribuição dos solos}

Os dados a respeito das descrições morfológicas estão indicados nos anexos (Apêndice 1). As Figuras 5 . e 6 ilustram a distribuição dos solos nas duas paisagens estuda das. Na Tabela 3 é apresentado um resumo das características morfológicas, físicas e químicas dos solos referentes aos perfis das áreas I e II.

A distribuição dos solos na superfície atual das duas áreas está relacionada aos elementos de uma paisagem de acordo com os critérios de RUHE (1961) (Figuras 5 e 6). Na área I (Figura 5) o perfil PC-1 estaria situado na encosta em relevo ondulado, enquanto que os perfis PC-2, PC-3 e PC-4 localizam-se no pedimento superior, médio e inferior, respectivamente, em relevo plano a suave ondulado. Na área II (Figura 6) na crista encontra-se $\mathrm{PC}-8$ em relevo ondulado, o perfil PC-5 sicua-se na encosta em relevo forte ondulado, enquanto que os perfis PC-7 e PC-7, localizam-se no pedimento superior e médio respectivamente, em relavo suave ondulado. A inserção do perfil PC-8, na sequência de solos da área II (Figu ra 6) teve a finalidade de mostrar a existência de solos enterrados, na parte baixa (PC-7) como na parte alta (PC-8) da sequência.

A. natureza da cascalheira e/ou linha de pedra, indicada nas Figuras 5 e 6 , é de material laterítico associado com bauxitos. E mais espessa nas quebras do relevo e mais delgada nas áreas mais plana.

A sequência de horizontes destes solos de uma maneira geral é A, B, C, com variações para A(B)C (perfis $P C-1$, PC-2, PC-5 e PC-8). A presença neste caso de atributos câmbicos é somente morfológicos e relacionado principalmente à espessura. Os perfis PC- 8 e PC- 7 são "bussequa" ou seja com sequência, $A, B, A b, B b$ característico de paleossolos en terrados. O perfil PC-5 pode ser considerado como um paleos- 

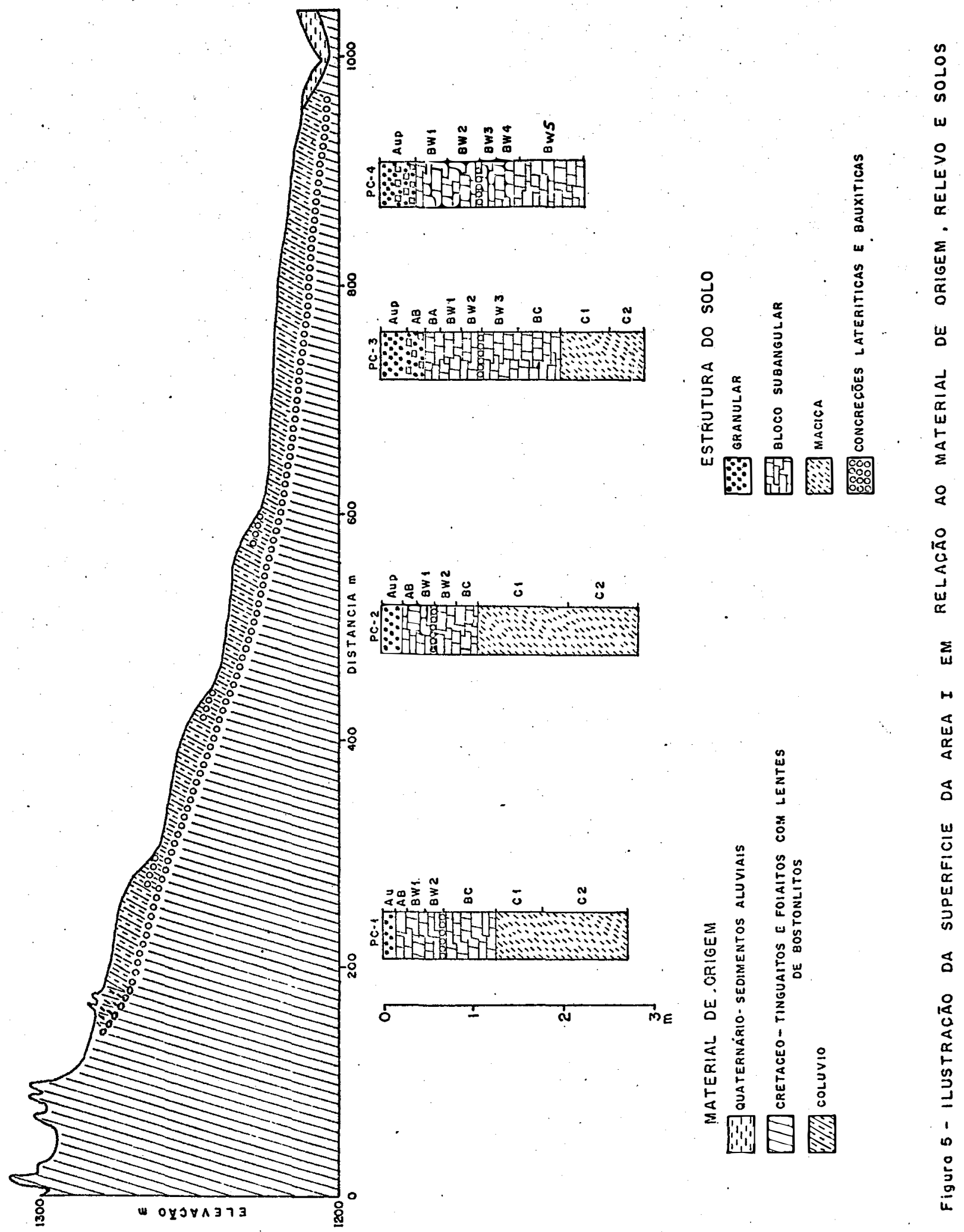


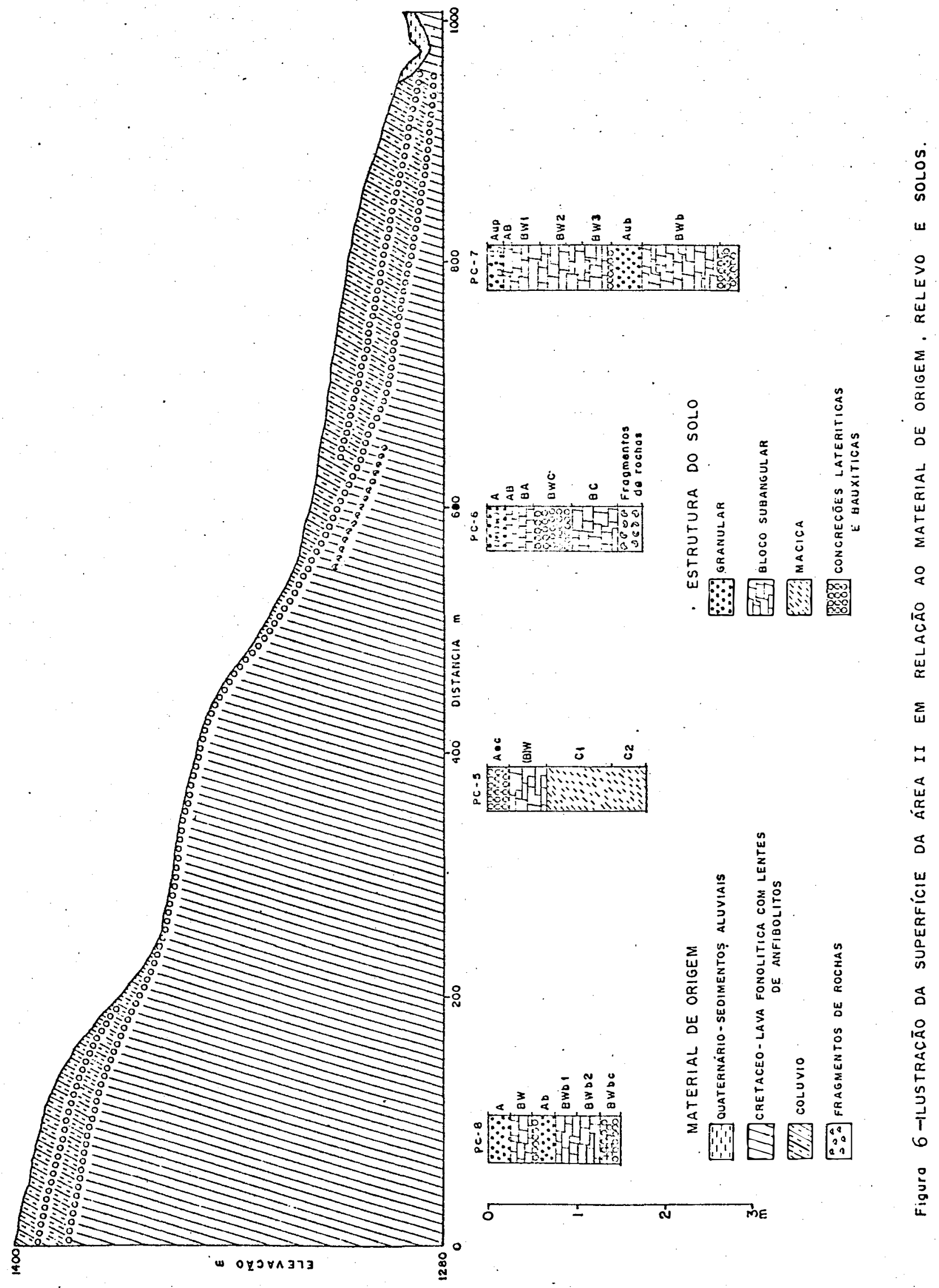




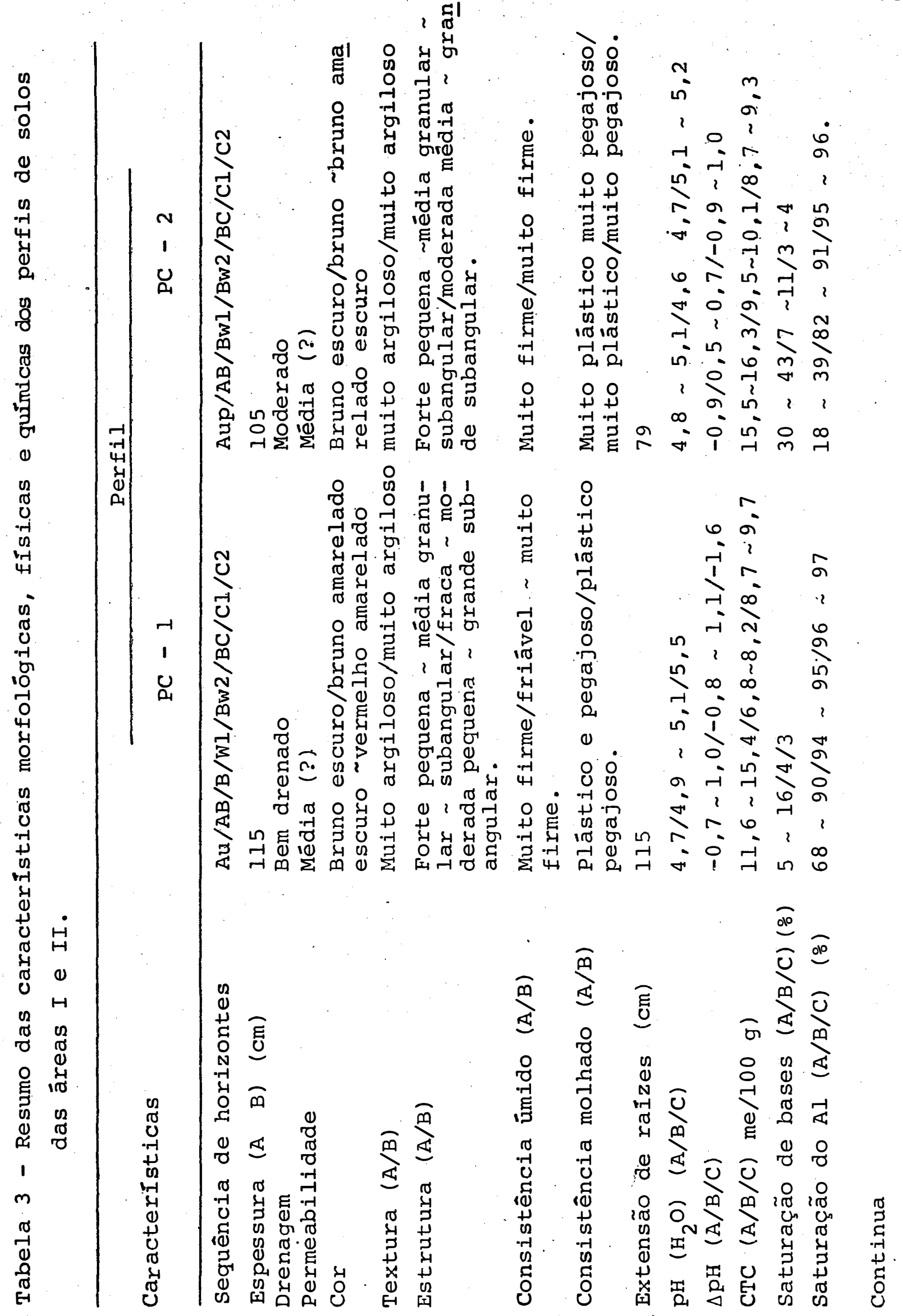




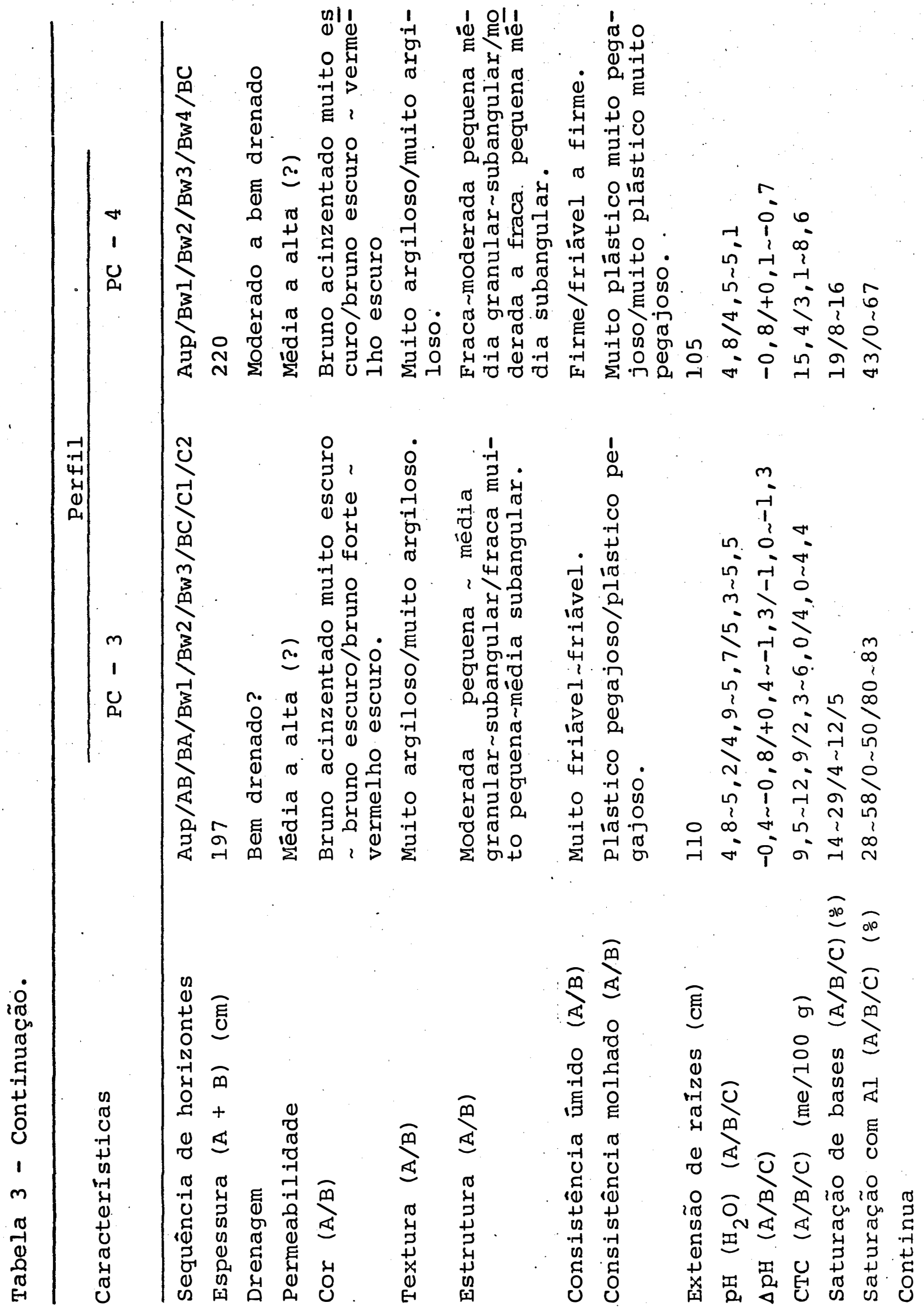




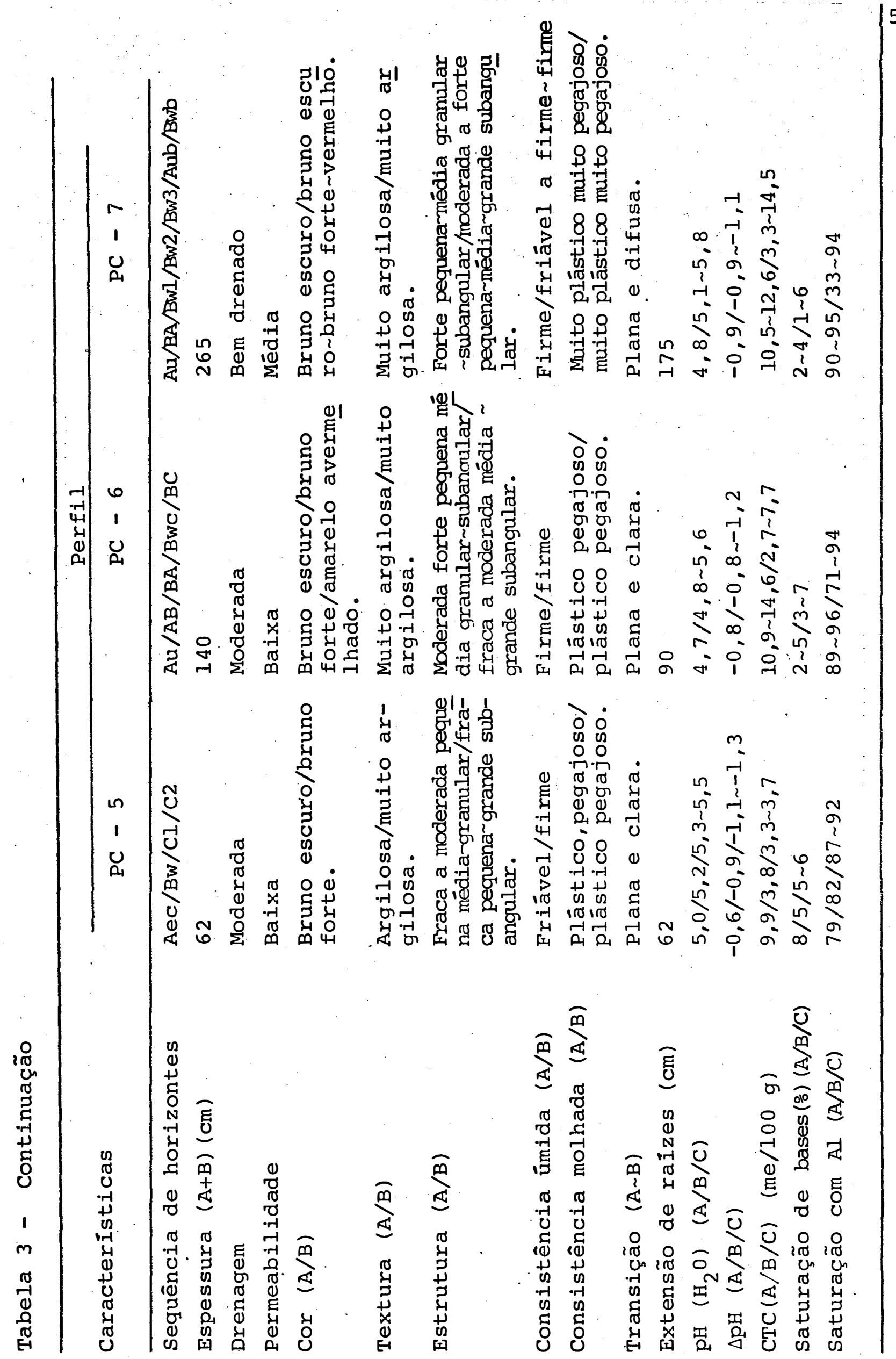


solo exumado (Figura 7). As Figuras 8 e 9 ilustram a ocorrên cia do horizonte Ab (enterrado), nas áreas I e II.

De uma maneira geral, a drenagem interna destes solos pode ser considerada como boa. Entretanto, é possivel encontrar sinais parciais de gleização no PC-5, mais especificamente nos horizontes $\mathrm{Cl}$ e $\mathrm{C} 2$, apesar deste perfil ocupar uma posição relativamente elevada na paisagem. Trata-se portanto de una paleodrenagem. A Figura 7 indica esta drenagem reduzida com cores cinzento claro no matiz lOYR.

Morfologicamente estes solos apresentam, grau de desenvolvimento de estrutura pouco variável, com maior di ferença observada em relação ao perfil PC-7 de estrutura em blocos subangulares. Como este perfil localiza-se no final do pedimento (vertente) é possível que este maior grau de de senvolvimento pode estar relacionado ao fluxo lateral de água. MONIZ e BUOL (1982) observaram que o maior desenvolvimento de estrutura nas encostas deve-se à ação do fluxo late ral de água pela alternância de ciclos de saturação e seca gem.

A sequência de horizontes $B$ nos perfis $\mathrm{PC}-1$, PC-2 na área I e o perfil PC-8 na área II (Figura 10), com estrutura em blocos subangulares médios a grandes podem estar em parte relacionado à herança estrutural do material de partida, que apresenta-se em alguns locais fraturado e ao intemperizar-se transfere sua forma ao tipo de estrutura. A diferença no grau de desenvolvimento da estrutura de fraca a moderada no horizonte $B$ do perfil PC-3 para moderado a forte no PC-4, na parte mais inferior do pedimento (vertente) também está relacionado à ação do fluxo lateral de água. 

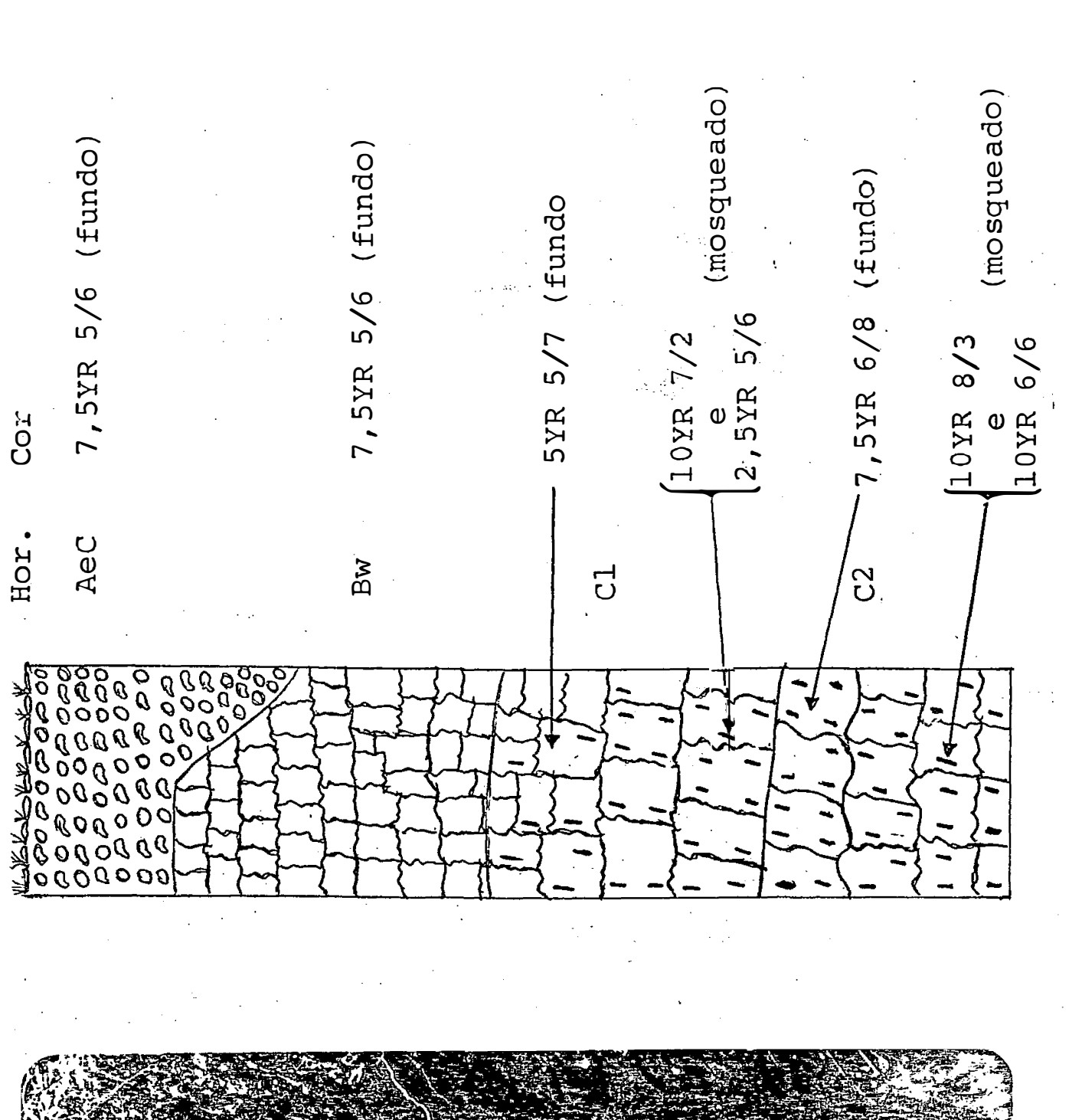

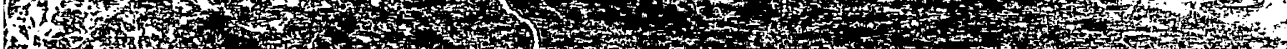

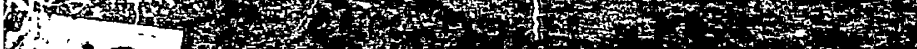

an

W

\section{?}

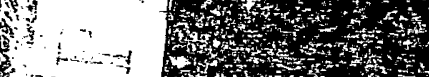

D

(6)

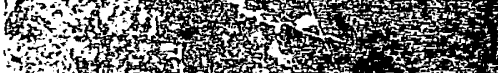

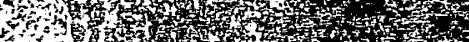

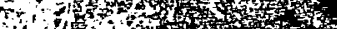

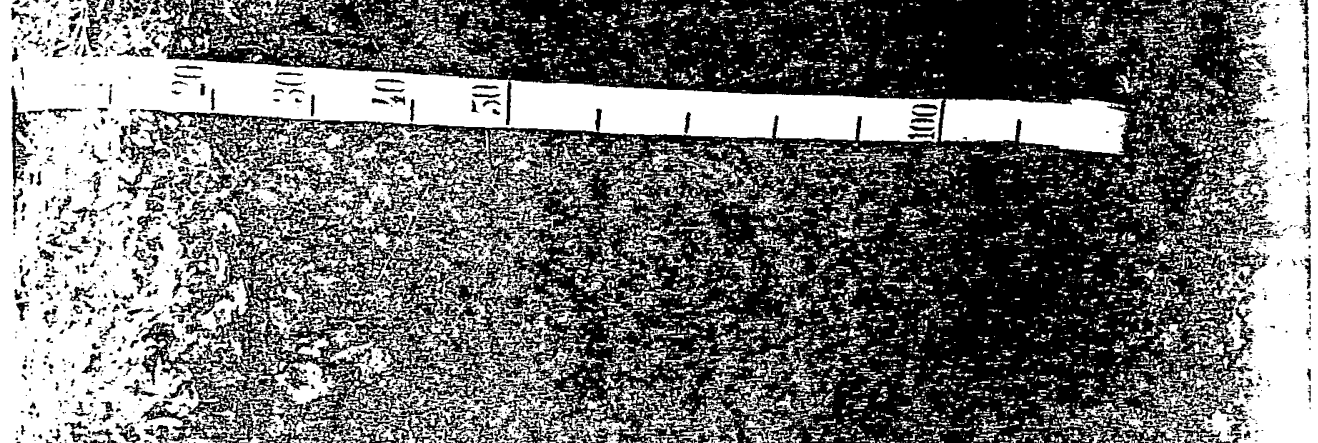

$+$

O $\sigma$

$\mathrm{N}$

던

동

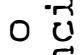

윰

cri

4 (1)

$+$

O ขั

无 U

in (1)

Un

H

-4 0

H.

$\stackrel{0}{0} \mathrm{~N}$

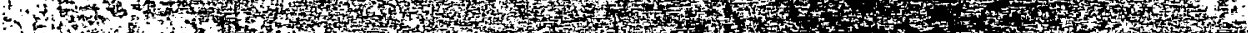

1.1.

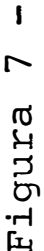




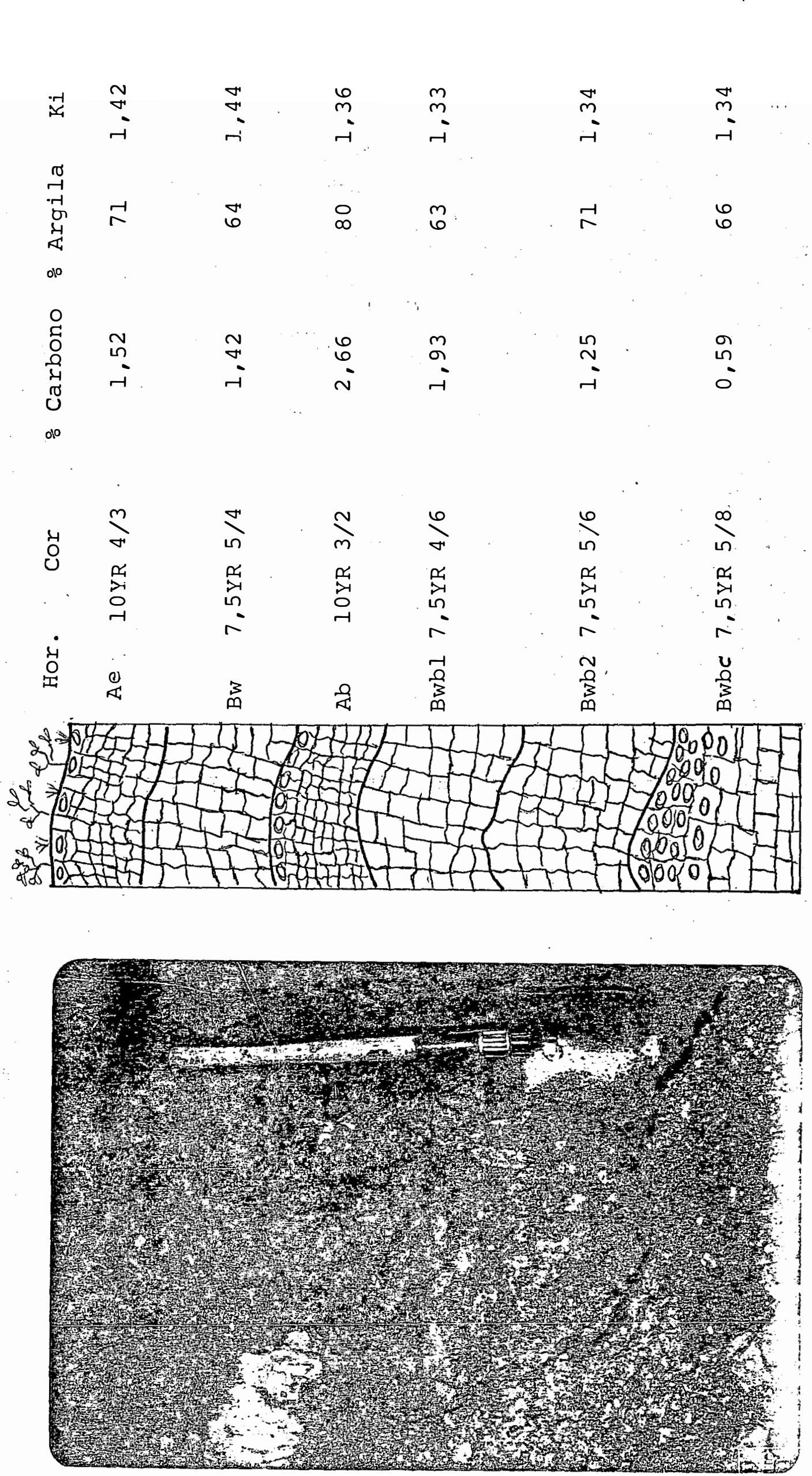

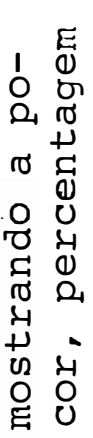

मं

$H$

r 20

(1) Un

प्र

$\because 4$

ס

(1)

.

ठช

H.

$4+$

(1) 5

는

is U

它

๘

苗

थ

मे 0 U

0 ,

U

గo

(1) $N$

宑 芹

ठ0

나 다

U

U) U

0

(1) 00

茴

(1) 도

4

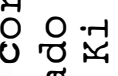

प्र 0

प्t

(1)

ह

(1) ट त्र

0 芩

$\infty$ न

1 थ

ن 0 号

ค $\mathrm{O}$ ○

त 4

Чै।

40

ڤ

I

$\infty$

10

先

or

ज्ञ 
60.

in

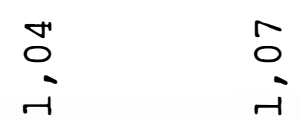

$\stackrel{m}{\infty}$

in

no

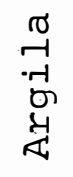

$\stackrel{\infty}{\infty}$

๙

으

\begin{tabular}{ll}
0 & 0 \\
0 & 0 \\
0 & $\sigma$ \\
4 & 7 \\
4 & -1 \\
4 & 0 \\
0 & 0 \\
+1 & 4 \\
\multicolumn{1}{c}{} & $\sigma$ \\
0 & 0
\end{tabular}

010

$O$
$\mathcal{1}$
0
0
4
0
U
010

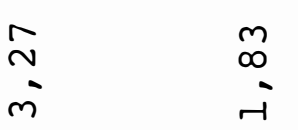

io

a

in

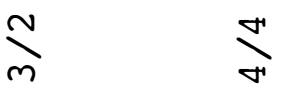

m

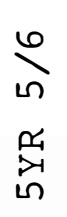

$\sum_{>}^{6}$

资

$\underset{n}{n}$

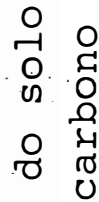

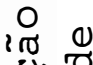

芩

茶

in

o:

崖汸

登

证
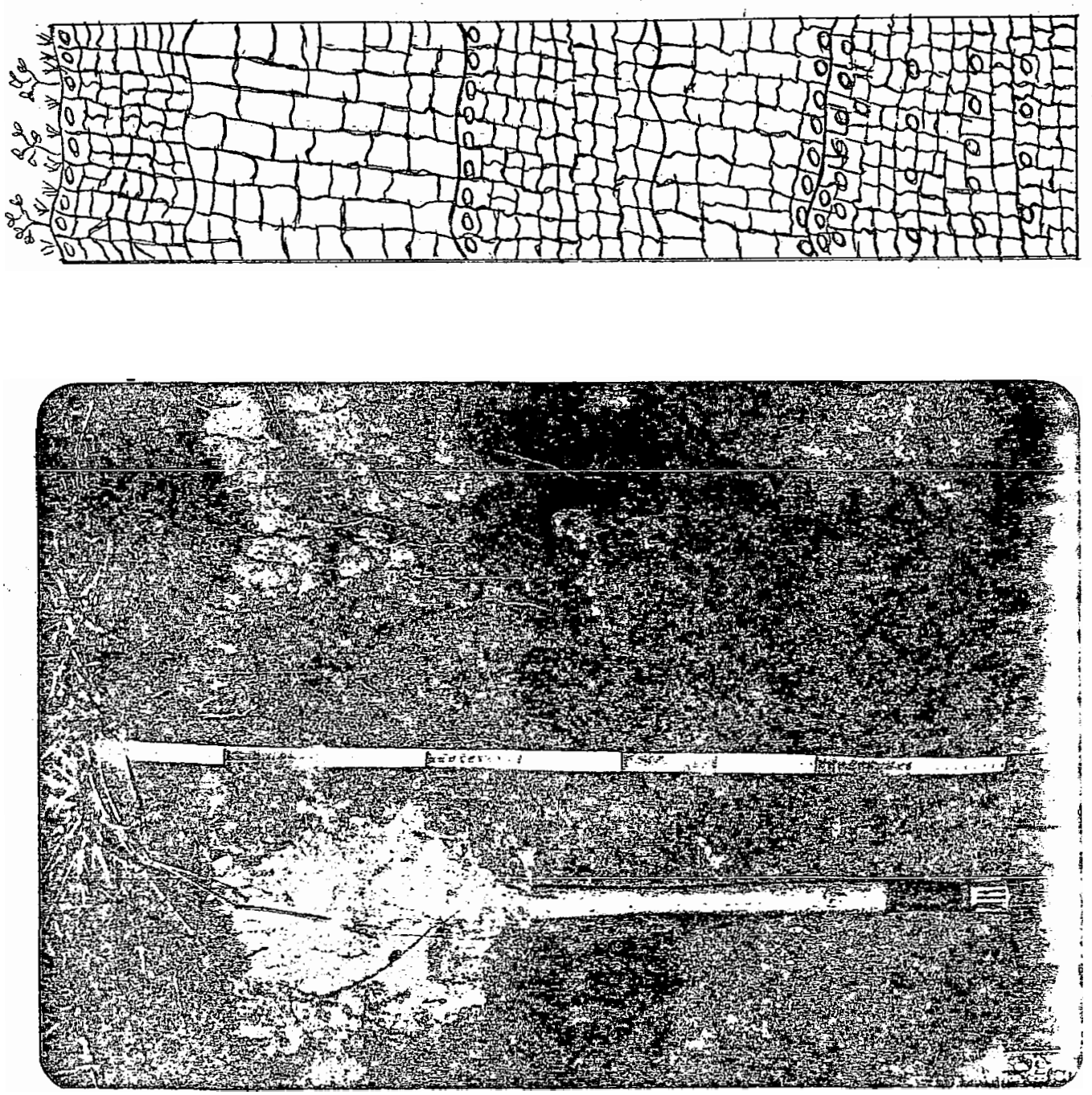

un

㲾

ค

r +

$0 \stackrel{0}{0}$

虽

\%

ț

O

芩 O

:

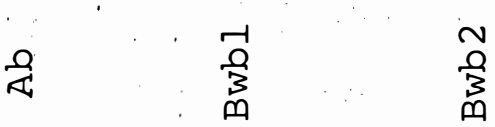

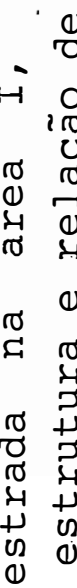

ه 00

官 $+$

(1) 00

+ م $N$

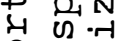

0 бo 4

0.

ह ${ }^{\circ} \mathrm{O}$

00

or

- 02

-1 O

प्रुन न

م.

I

a

ro

วั้

$-\rightarrow$ 


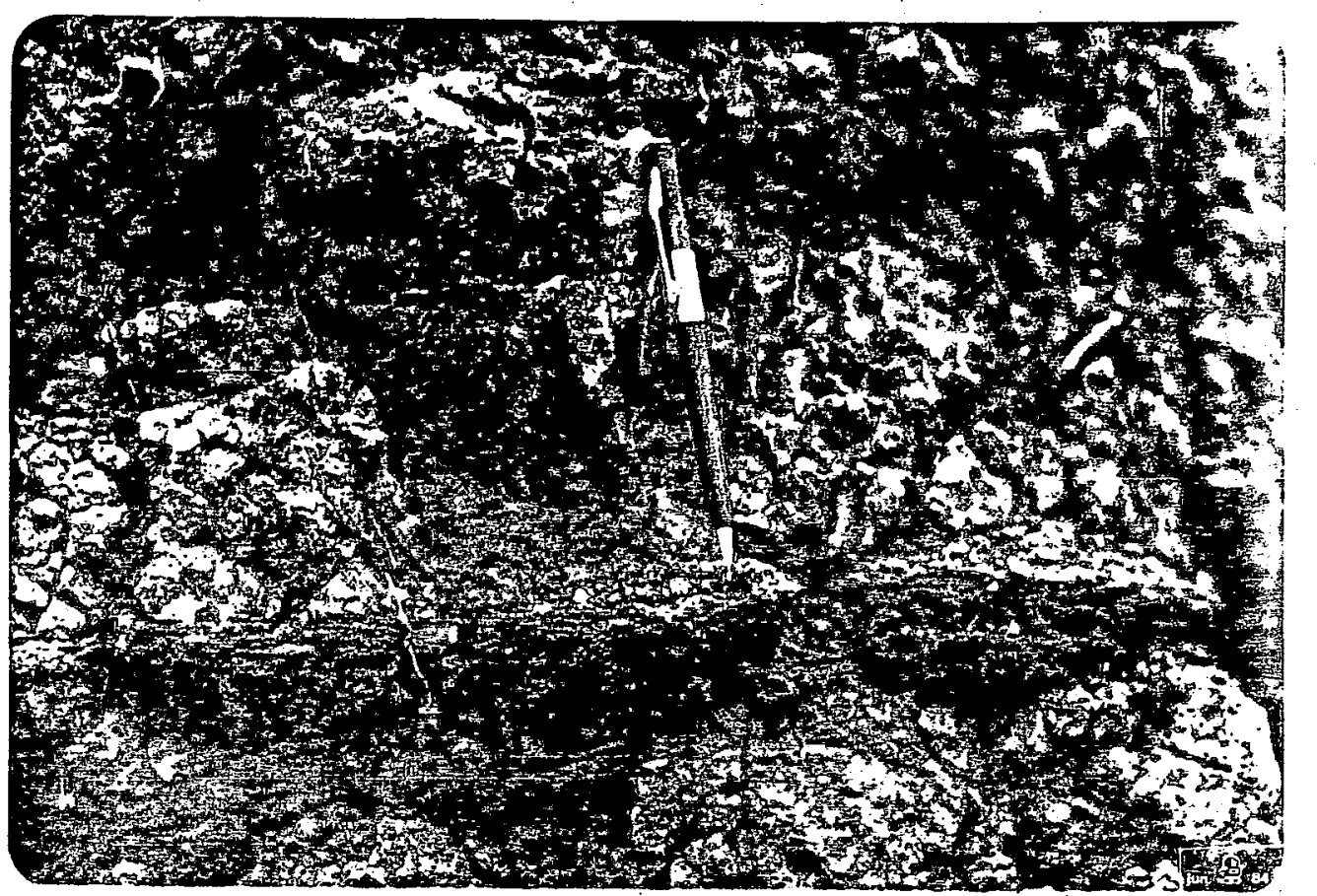

A

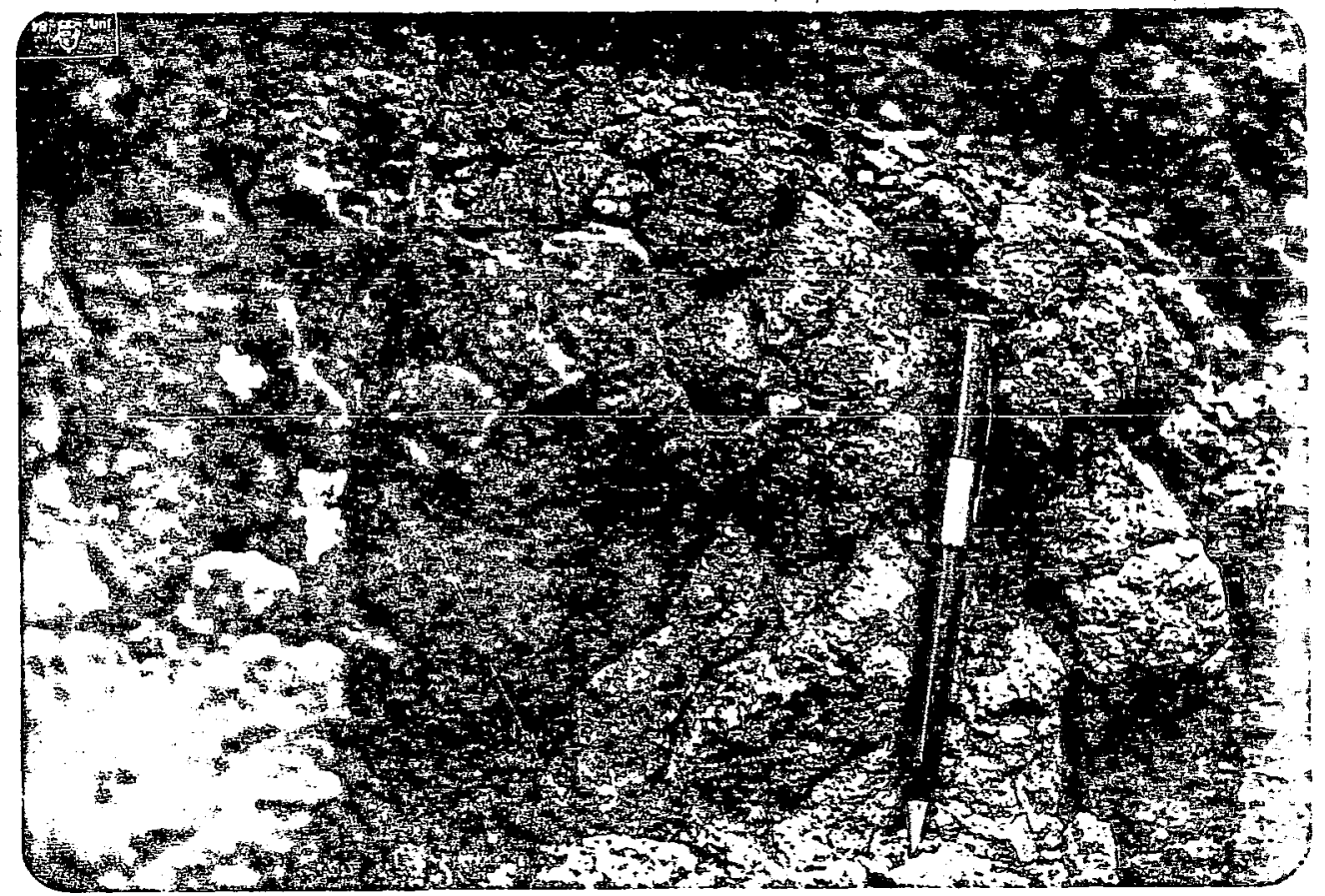

Figura 10 - Perfil PC-8 na área II mostrando o aspec.to da estrutura herdada do material de partida, indicada pela parte superior da caneta nas fotos A e B. Na foto A indicada pela ponta da caneta observa-se uma lâmina resultante da segregação de ferro, tendo na parte superior deste concreçôes bauxíticas. 
E frequente observar-se nos cortes de estradas os solos secos apresentarem estrutura em forma prismática com posta de blocos subangulares fortemente desenvolvidos (Figura 11). Isto deve refletir um processo de umedecimento e seca mento rápido dos solos, pela presença de algum material no so lo que tenha a propriedade de retrair-se pela perda rápida de água nas condições ambientais. Esța característica parece ser um reflexo da presença de material amorfos (alofanas) e/ou haloisita nestes solos. PESSOA (1979) observou em solos da Bahia que o desenvolvimento moderado da estrutura em blocos , no horizonte $B$ de latossolos e podzólicos,devia-se a presença dominante da metahaloisita na fração argila desses solos.

A cor destes solos de uma maneira geral parece estar relacionada em parte a alteração do material de partida, que apresenta cores bruno forte, amarelo avermelhado (tinguai tos) e cinzento (bostolitos) e a natureza dos óxidos de ferro. $\mathrm{Na}$ parte inferior do horizonte B dos perfis PC-3, PC-4 e PC-7, as cores variam de vermelho a vermelho escuro. VOLKOFF (1978) estudando os produtos ferruginosos que determinam a cor de so los da Bahia, observou que a cor amarela está associada à pre sença de goethita e a cor vermelha refere-se à presença de he matita, principalmente em forma de cristais muito pequenos: SCHWERTMANN et alii (19892) observaram também que solos com he matita apresentam cores mais vermelhas que 7,5YR, enquanto que, solos goethiticos livres de hematita mostram matizes brunos amarelados entre 2,5Y e 7,5YR e quando goethita e hematita ocorrem associadas domina a cor vermelha da hematita. As cores vermelhas na parte inferior desses perfis podem estar relacionadas ao desenvolvimento mais intenso do solo em fase pa leoclimática mais quente e seco que favorecem a formação de hematita (SCHERTMANN, 1971), evidenciando oscilação paleoclimática na formação dos paleossolos. A coloração escuro do ho rizonte $\mathrm{A}$ e mesmo dos horizontes $\mathrm{Ab}$ destes solos deve-se aos altos teores de matéria orgânica presente. 
63.

$m$

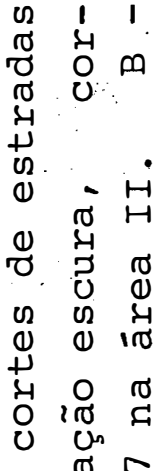

3
3

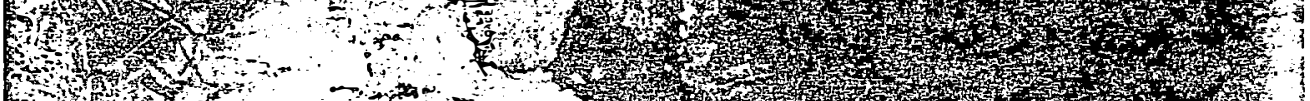

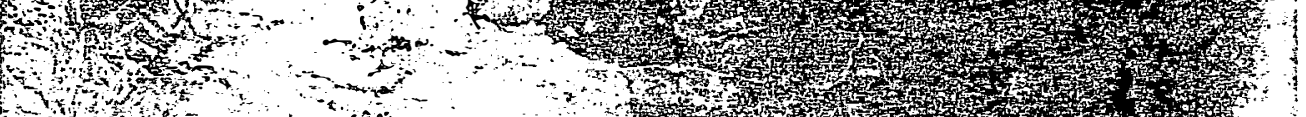

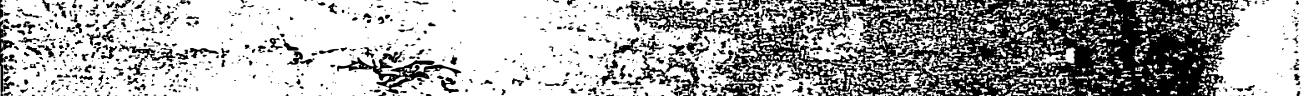

(n)

Fon

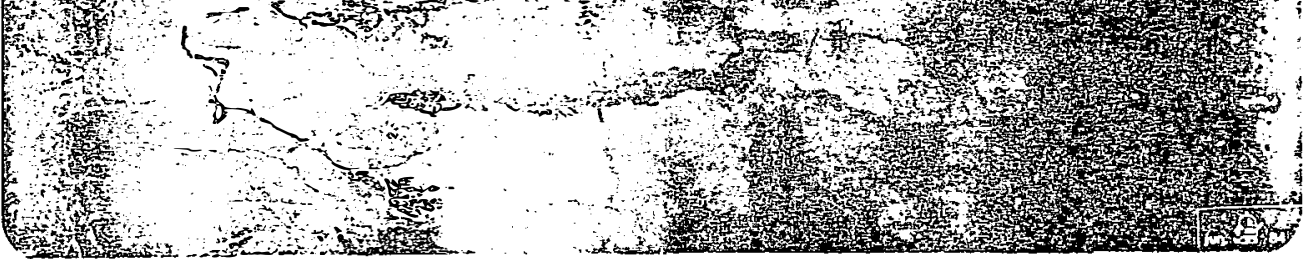

$\mathbb{4}$

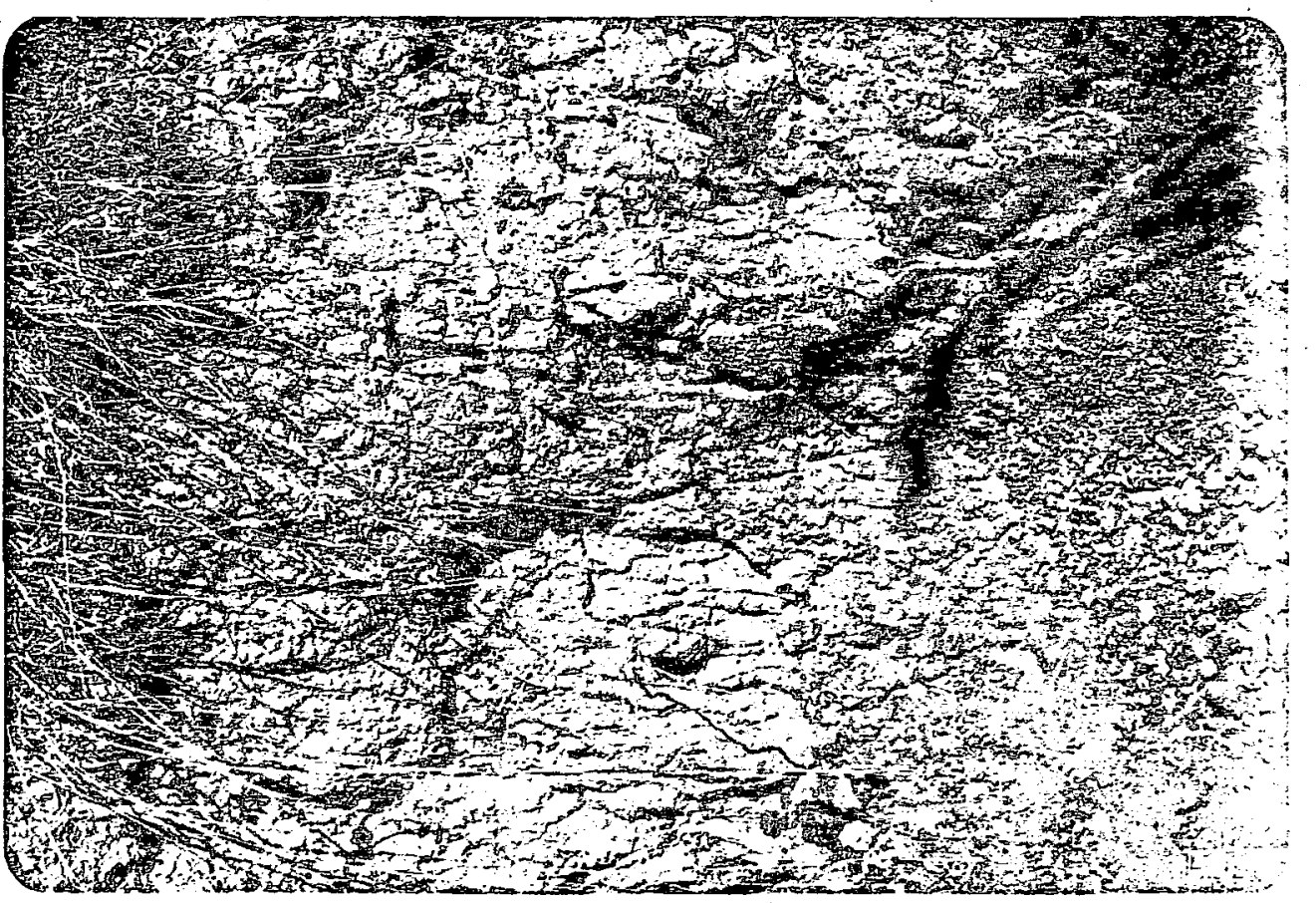

U म 1

000

द नी D

ธ. 00

รู)

प्ठ

(a)

(1)

थ द 10

(1) O प्र

r

ช प्र

O d

द 0 पै

岂 0 U

-

$\rightarrow 00$

4

3 ர 0

द

1)

ब त्र

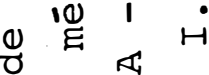

(1)

त) मे. 0 मे

4 त

б) 0

० 0 U

ह 乙 $\mathrm{O}$ \%

( $\dot{0}$ न

+ ० 0

U 0 U

일

$\begin{array}{llll}0 & 0 & 0\end{array}$

O

O 0 今 0

फ द स

U \begin{tabular}{lll}
0 & 0 & 0 \\
\hdashline & 4 & 0
\end{tabular}

-1

$\sigma$

นี

[4 
A classe de textura destes solos é argilosa e mui to argilosa, refletindo a intensa alteração que sofreram os materiais constituintes das rochas, sob ação dos processos de intempe rismo quỉmico dominantes na área. Esta intensa alteração é a consequência da ação do clima na área, aliada à predominância nos materiais constituintes das rochas de minerais primärios menos resistentes ao intemperismo.

A cerosidade observada no solo úmido, não foi constatada nos cortes secos com lupa de $10 \mathrm{x}$, sugerindo com is so a ocorrência de filmes de água revestindo as superfícies dos elementos de estrutura e não de cerosidade.

Considerando-se as características morfológicas, estes solos podem ser considerados como profundos a mediana mente profundos, bem a moderadamente drenados, porosos e de permeabilidade média a alta. O horizonte A apresenta características de cor, espessura e teor de carbono que satisfazem um horizonte A moderado (epipedon ócrico) ao perfil PC-5 e o horizonte $A$ proeminente (epipedon úmbrico) aos demais perfis. Os solos correspondentes aos perfis PC-3 e PC-4, morfologicamente são semelhantes aos Latossolos, enquanto que, os demais perfis assemelham-se aos Cambissolos.

Convém salientar que a designação de horizontes (B) para os perfis $\mathrm{PC}-1, \mathrm{PC}-5$ e $\mathrm{PC}-6$ se deve unicamente a menor espessura quando, comparado com os perfis $\mathrm{PC}-3$ e $\mathrm{PC}-4$ e com maior grau de desenvolvimento de estrutura no PC-7. Entretanto, a ausência de gradiente textural em todos os perfis designados como (B), assim como a ausência de fragmentos de rochas na sua massa não o definem, morfologicamente, como horizontes câmbicos. 
Os horizontes enterrados. Bb (perfis PC-4, PC-7 e PC-8) possuem estrutura em blocos subangulares de grau fra co a moderado, característica inclusive de horizontes óxicos. Nestes horizontes enterrados, assim como, o do perfil PC-5 po dem ser considerados como sendo óxicos.

A caracterização dos Latossolos Brunos e Terra Bru - na Estruturada, típicos dos perfis PC-3, PC-4 e PC-7, . respectivamente, seriam semelhantes morfologicamente aos oxissolos típi cos, com uma única diferença para o grau mais desenvolvido de estrutura. Convém levar em consideração que a Soil Taxonomy, na definição de oxissolos admite subgrupos Tropeptic, justa mente para casos como aqui apresentados.

\subsection{Propriedades físicas}

As propriedades físicas referentes a distribui ção de partículas, densidade aparente e retenção de umidade variam pouco entre os solos.

A granulometria dos solos são apresentadas no Apêndice I e Tabela 4, onde os teores de areia são bastante baixos, os de silte mais variáveis oscilam entre 11 a $40 \%$ e de argila superior a $43 \%$, podendo atingir valores de $85 \%$. A diferença entre os perfis em relação à distribuição de particulas, assim como, o gradiente textural è muito pequeno, insu ficiente para que caracterize requisito à identificação como horizonte B textural ou argílico (BENNEMA e CAMARGO, 1964 e ESTADOS UNIDOS, 1975).

Nos perfis PC-1, PC-2 e PC-6 ocorre um decréscimo na quantidade de argila com um aumento relativo de silte e/ou areia a partir do horizonte $B C$; enquanto que, nos perfis 


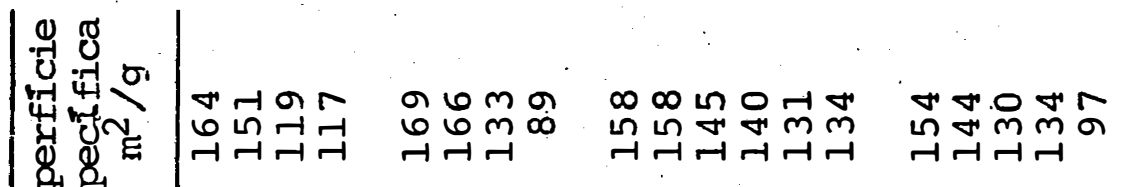

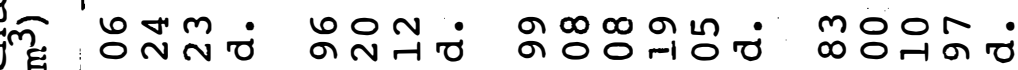
प

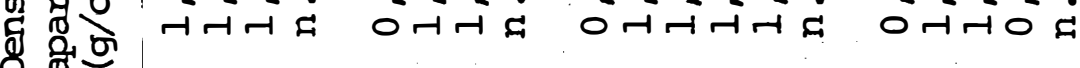

in 000 O

NNmN arid HतO

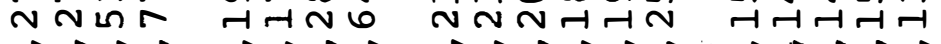
O000 0000

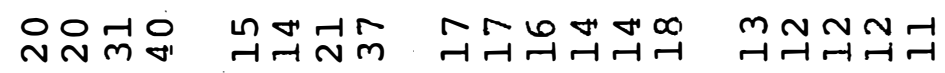

Nin엉 द

兽

Nin in in

$\rightarrow \rightarrow \underset{1}{1}$

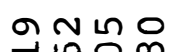

no $\infty$ m no

N $\ln$ 능ㅇ

N $\begin{array}{lllllllllllll}1 & 1 & 1 & 1 & 1 & 1 & 1 & 1 & 1 & 1 & 1 & 1 & 1\end{array}$

员 


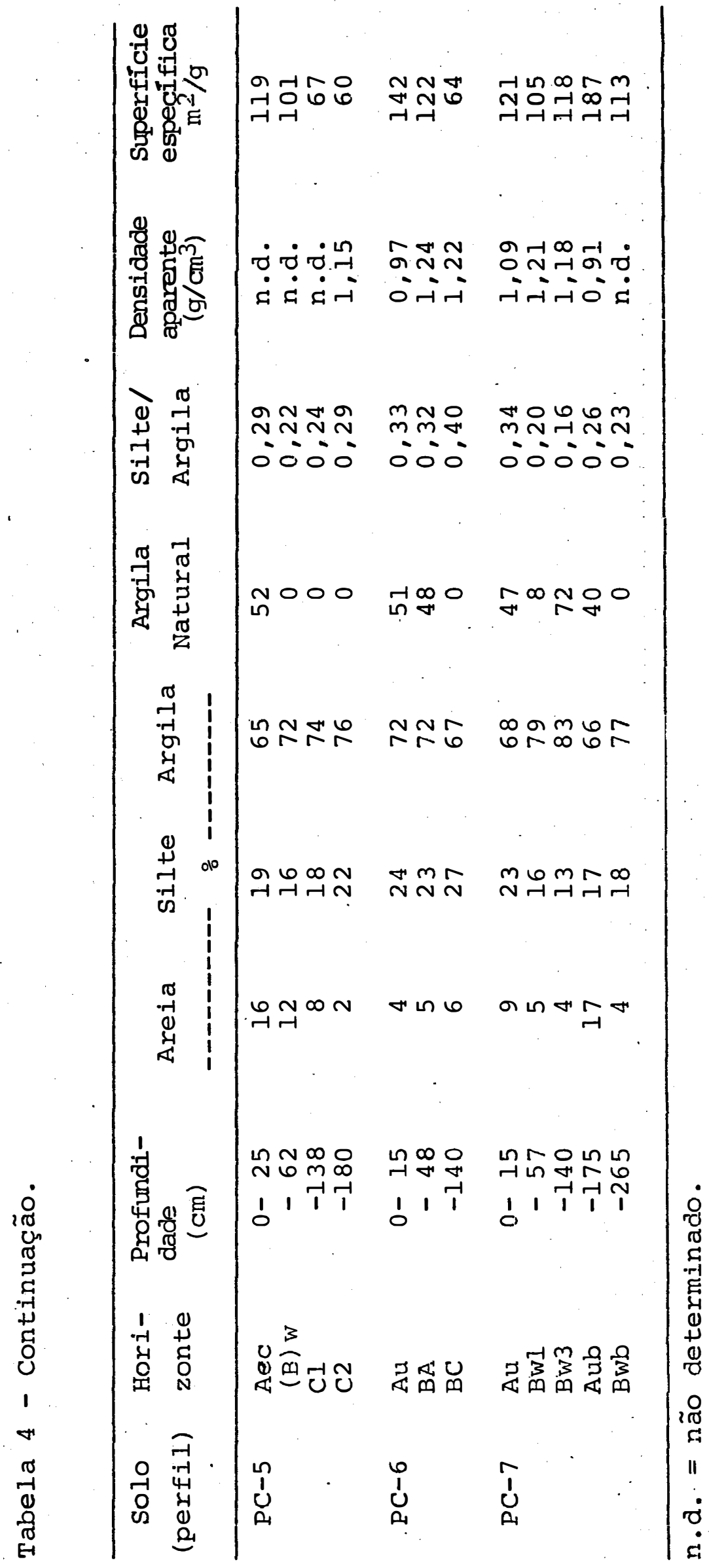


PC-3 e PC-4 ocorre a partir do Bw3 e perfil PC-7 do horizonte Aub. Isto pode estar relacionado a um menor grau de altera ção do material de partida e à presença de concreções e nódulos lateríticos e bauxíticos no tamanho da fração silte e areia na massa do solo.

A relação silte/argila nestes solos varia em geral de 0,13 a 0,40, demonstrando que o material do solo encontra-se bastante alterado, com exceção para os horizontes mais inferiores dos perfis PC-1 e PC-2, que apresentam valo res mais elevados variando de 0,43 a 1,02. VAN WAMBEKE (1962) mostrou uma tendência deșsa relação em diminuir nos solos tropicais mais alterados. Os valores desta relação não apresentam uma tendência geral. Assim, é que ela aumenta com a profundidade do solo nos perfis $\mathrm{PC}-1$ e $\mathrm{PC}-2$ e ligeiramente pa ra o PC-6, denotando um menor grau de alteração dos materiais do solo em profundidade; para os perfis PC-4 e PC-7 (paleos solos) a relação silte/argila do $\mathrm{Bb}$ é semelhante ou menor que - B, provando o avançado grau de intemperismo, que o exclui da definição de câmbico. Comparando-se os valores da relação silte/argila dos solos entre si, nas duas áreas, observa-se que os solos mais alterados são os correspondentes aos perfis $\mathrm{PC}-3, \mathrm{PC}-4$ e $\mathrm{PC}-7$.

A argila dispersa em āgua nos solos da área I ocorre nos horizontes superficiais, enquanto que, na área II aparecem tanto no horizonte $A$ como no horizonte $B$ dos perfis PC-6 e PC-7. Isto é atribuido aos valores mais altos de $\Delta \mathrm{pH}$ encontrado nestes solos. GILLMAN (1974) tem observado que quando aumenta a magritude de carga negativa ou positiva a susceptịbilidade da argila dispersar também aumenta. A magni tude do aumento da carga elétrica negativa nestes dois perfis (PC-6 e PC-7) parece estar relacionado aós teores mais eleva- 
dos de matéria orgânica ao longo desses perfis (PC-6 e PC-7) que tem a propriedade de aumentar a carga elétrica negativa nos solos em pH ácido.

A densidade aparente determinada nos solos varia de 0,83 a $1,24 \mathrm{~g} / \mathrm{cm}^{3}$ (Tabelas 4 e 5 ) estando estes valo res em sua maioria concordantes com os de solos argilosos que variam em geral de 1,00 a $1,25 \mathrm{~g} / \mathrm{cm}^{3}$. Os valores inferiores a 1,00 encontrados nestes perfis relacionam-se aos teores mais elevados de matéria orgânica nos horizontes superficiais e subsuperficiais (dos perfis PC-4 e PC-7 horizonte Bw3 e Aub , respectivamente). Os valores de densidade aparente $<1,00 \mathrm{~g} / \mathrm{cm}^{3}$ observados os horizontes subsuperficiais com baixos teores de matéria orgânica, parece envolver uma maior porosidade do solo nesses horizontes.

Os valores de densidade aparente referentes ao horizonte B, são mais altos nos perfis PC-1, PC-2, PC-6 e PC-7, refletindo o maior desenvolvimento de estrutura e menor grau de porosidade nesse horizonte. MONIZ e BUOL (1982) observaram uma-relação entre a densidade aparente e o desenvolvimento de estrutura de solos, com os valores $>1,15 \mathrm{~g} / \mathrm{cm}^{3}$ relacionados à estrutura em bloco subangular ou média a grande granular e $<1,15 \mathrm{~g} / \mathrm{cm}^{3}$ para estruțura muito pequena granular.

Os resultados da superfície especifica total de horizontes selecionados dos perfis para análise mineralógicas variam de 64 a $187 \mathrm{~m}^{2} / \mathrm{g}$ (Tabela 4). Os valores de su perfície especifica decrescem gradativamente com a profundida de, exceto no perfil PC-4 e PC-7, onde ocorre uma elevação da mesma nos horizontes Bw3 e Aub, respectivamente, devido à pre sença de teores elevádos de matéria orgânica nesses horizon tes. Estes valores de superfície específica são mais altos do que os previstos para solos contendo predominância de cau- 
linita e gibbsita, com evidências da presença de outros compo nentes no solo com superfície específica mais elevada, como material amorfos e micas.

A variação observada nos valores de densidade aparente e superfície específica nos horizontes subsuperfi ciais dos perfis PC-4 e PC-7, com aumento de matéria orgânica, pode ser considerada como mais uma evidência da presença de solos enterrados nestas áreas.

Os dados de retenção de água determinados em amostras de terra fina (<2 mm) são apresentados na Tabela 5, juntamente com os de argila, determinada e calculada. Estaúltima com ba se em 2,5 vezes a percentagem de água retida a 15 atmosferas, (ESTADOS UNIDOS, 1975). A percentagem de água retida sob as tensões de 0,33 e 15 atmosferas apresenta diferença relativamente pequena entre os perfis, e mesmo entre os horizontes, co mo podem ser observados nos dados da Tabela 5 e curvas caracte risticas de umidade de alguns horizontes dos perfis (Figuras 12 e 13). A pequena variação na percentagem de água retida nestes solos está relacionada à textura muito argilosa e ao tipo de argila. A argila parece ser o principal fator responsável pelamagnitude da retenção de água nesses solos.. DEMATTE (1977) atribuiu que o conteúdo de argila, matéria orgânica e estrutura do solo foram os fatores mais importantes na retenção de água a baixas tensões ( $<1,0$ atmosfera), enquanto que, o conteúdo de argila e a mineralogia da argila pareceram ser mais importantes na reten ção de água a 15 atmosferas.

O conteúdo de argila calculada com base na retenção de água a 15 atmosferas em relação a determinada, apre sentam uma diferença bastante acentuada nos horizontes mais inferiores dos perfis. A diferença existente entre o conteú- 


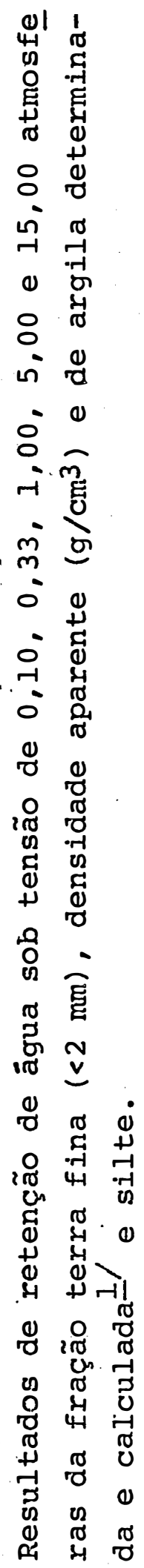

in
का ब6नत

$m m m m$ ㄴ ०000000

다 :

竎

किन्न|

ro

कृत .

每

إل

तீ

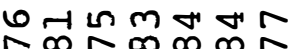

กำ

ब0 NनTन

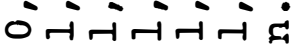

નનનનનન્વ

$m \forall n \infty a n$

rrag

-1ㅇ $m \infty \infty \infty$ $\infty \infty \infty N \in$ L

ro rmm nm

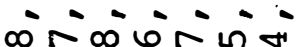

กัก ก N

in

त

L $m \sim m L N \infty$ ONंmimio

thm Oेंगिलंखिंत्म $\mathrm{mm} \mathrm{mmmm} m$

웅

in

ڤ్

(2)

ii do

o o.jhtho

$\infty \omega \infty 0 \infty \pi \infty$

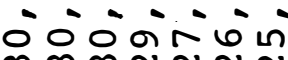

mm N N N

$m \operatorname{com} n \rightarrow$

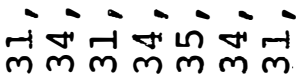

N $00000 N \pi \infty$

ONmmiñ

$\mathrm{mm} \mathrm{mm} \mathrm{mm} \mathrm{mm}$

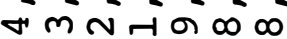

$m m m m \sim N$

$\infty 6 \sim \infty m+0$

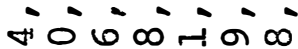

$m \forall m m$ Fr $m$

ONL

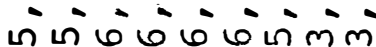
$\mathrm{mm} \mathrm{m} \mathrm{m} \mathrm{m} \mathrm{m} \mathrm{mm}$

orindath Oñnimin $\forall m m m$ m

$\infty m-100 m$ बिं

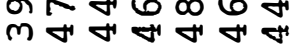

OOMONNMGa

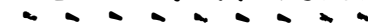
O ONNNATOA

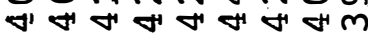

$\forall \infty m \sim \forall m$

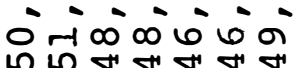

Alomatar ชั่ $m 6 \infty \sigma m+\infty N$ L

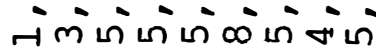

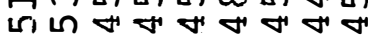

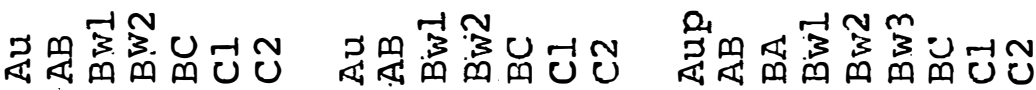<smiles>O[Hg]</smiles> 
तथ ब응 m m m F' $m$ F ०ि00ं0

a 6 Nm m $\nabla$ in 1 . ०000

MONR मrmm开 O००००

$-1 \infty \infty \infty$ in 0 N $\forall m m m m L$ 0.00000

$m \sim \sim \sim N-$

a) $6 \infty$

T $\min$

$m \circ 6 \forall m \sim \infty$ નનન્નન ન્ના

NNNT

N N

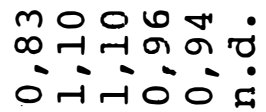

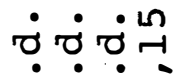

$\operatorname{nr} \cdot m$ - ando o nnado

द द द

विनंटं

-

नित्रं.

$\operatorname{NnNm}$

ㄲ 60

$\infty 06 \pi 0$ $\sim \infty \infty \infty \infty$ क वे० N

응ํำ

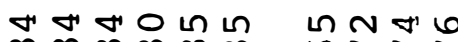
$\infty \infty \infty \infty \infty$ ond

NONM

$\infty \pi の \circ m \in N$

$\circ \mid \infty n \pi m m$ OंNंNंm เ $\forall \operatorname{m}$ $\mathrm{mmmmm}$ in $\min _{m}^{-\infty} \dot{m}^{-}$ noln Ln सं NNmLNOM

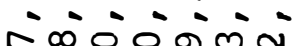
$m \sim N \sim m$ N $\mathrm{mm}$ m m

GaLnN नेंmं $\dot{m} \dot{m}$

Uก a 6 a N

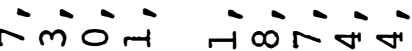
$\mathrm{mmmm}$ Nm\& mNNNm

rotrutm

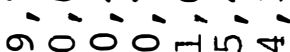
Nmmmmm

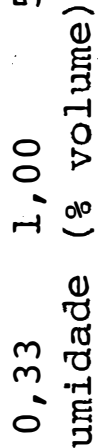

$\infty \pi 6 \ln$ 的的政 $m \mathrm{~mm} m$

$\ln N$ No $\infty \infty^{\circ}$ in

ON नेंगंत (1)

N $m m m \sim m$

$m \sim m m \sim n-1$ ming

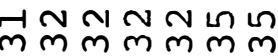
(1)

NuanN m.0ं $\infty m N r$

$\wedge \curvearrowleft \infty \sim \infty$ Nivi

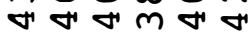
$m \forall$ in जिंबंm

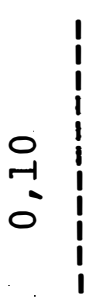

年 范

A $\infty \omega^{\circ} \dot{\infty} \infty$

$a n t r$

$\infty 0 . \infty 0 r$

$\infty \pi / \pi 06$

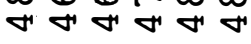
तिंकें Nंmin - i... mor un in $\forall \mathrm{m}$

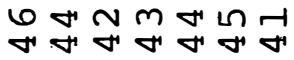

เn

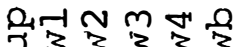

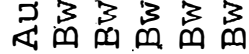

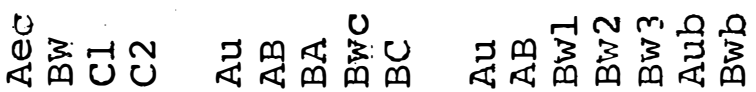

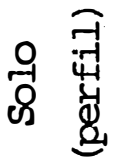
㭊

$n$
$\vdots$
$n$<smiles>[18O]</smiles><smiles>C[Hg]</smiles> 

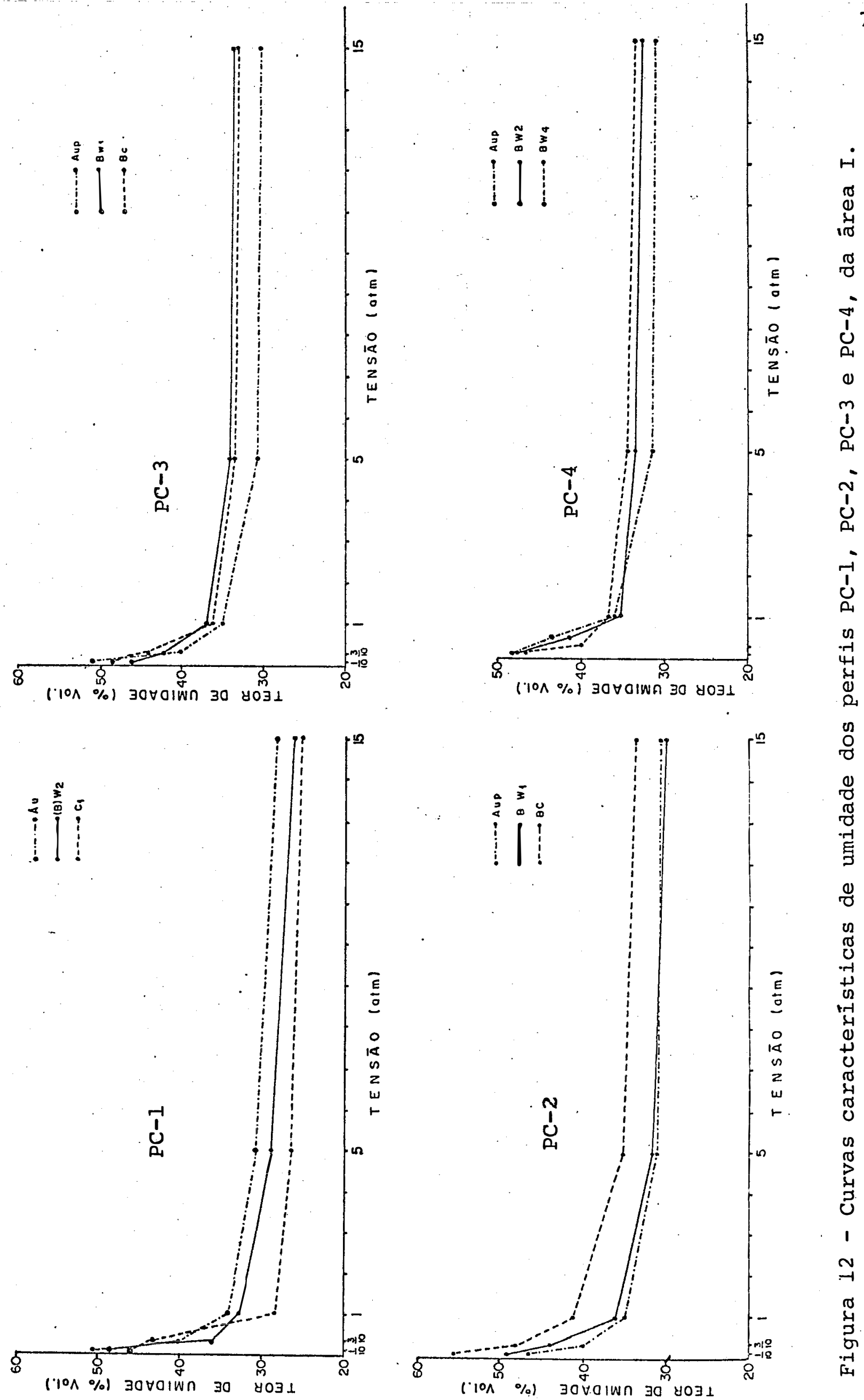

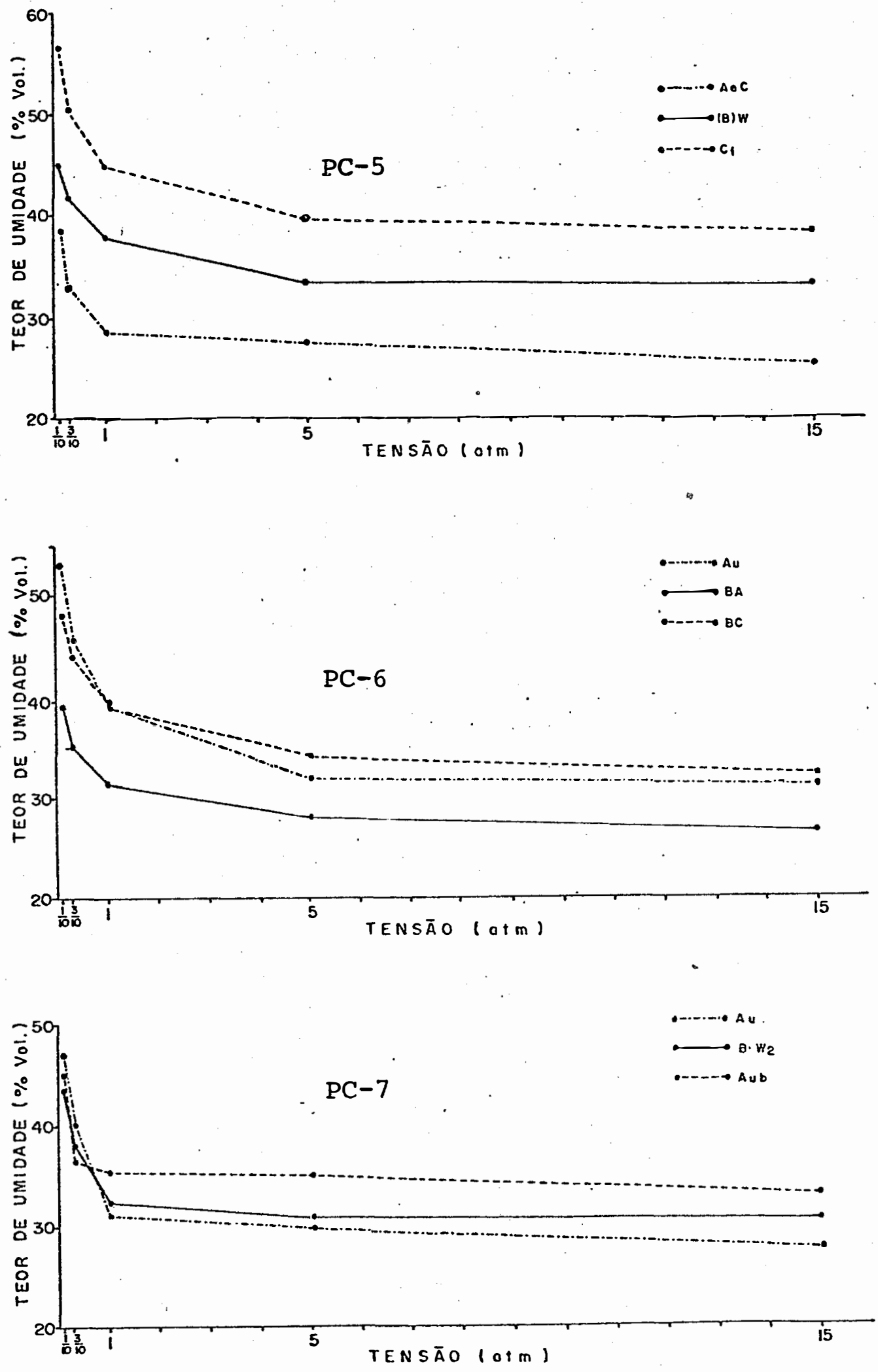

Figura 13 - Curvas características de umidade dos perfis PC-5, PC-6 e PC-7, da ārea II. 
do de argila determinada e a calculada, observada principalmen te nos horizontes mais inferiores dos perfis PC-1, PC-2, PC-5 e PC-6, está relacionada à presença de maiores quantidades de silte nesses horizontes que apresentaria comportamento semelhante ao da fração argila, em relação à retenção de água pelos solos.

Convém salientar, mais uma vez que, em relação as propriedades físicas não há diferenças significativas entre os perfis estudados. Por outro lado, principalmente quanto as características de textura, superfície especifica e densidade, são semelhantes a solos classificados como latossolos. Além disso, não há distinção, pelo menos nestas propriedades, entre os horizontes $\mathrm{B}, \mathrm{Bb}$ e (B).

\subsection{Propriedades químicas}

5.3.1. Matéria orgânica e tipo de humus

Os teores de carbono (Tabela 6 e Apêndice dos solos são extremamente variáveis de 0,03 a 3,63 \%, decrescendo, regra geral, com a profundidade. Entretanto, com rela = ção àos perfis $\mathrm{PC}-4, \mathrm{PC}-7$ e PC-8. isto não acontece, pe la ocorrência de valores altos de carbono também nos horizon tes Bw3 e Aub, respectivamente, onde observa-se dois segmentos nessa tendência (Figura 14), a qual relaciona-se à presença de solos enterrados.

Os teores elevados de carbono nos horizontes superficiais destes solos relacionam-se com a altitude da região e com a estabilização da matéria orgânica pelos colóides do solo associados coms Ions. 


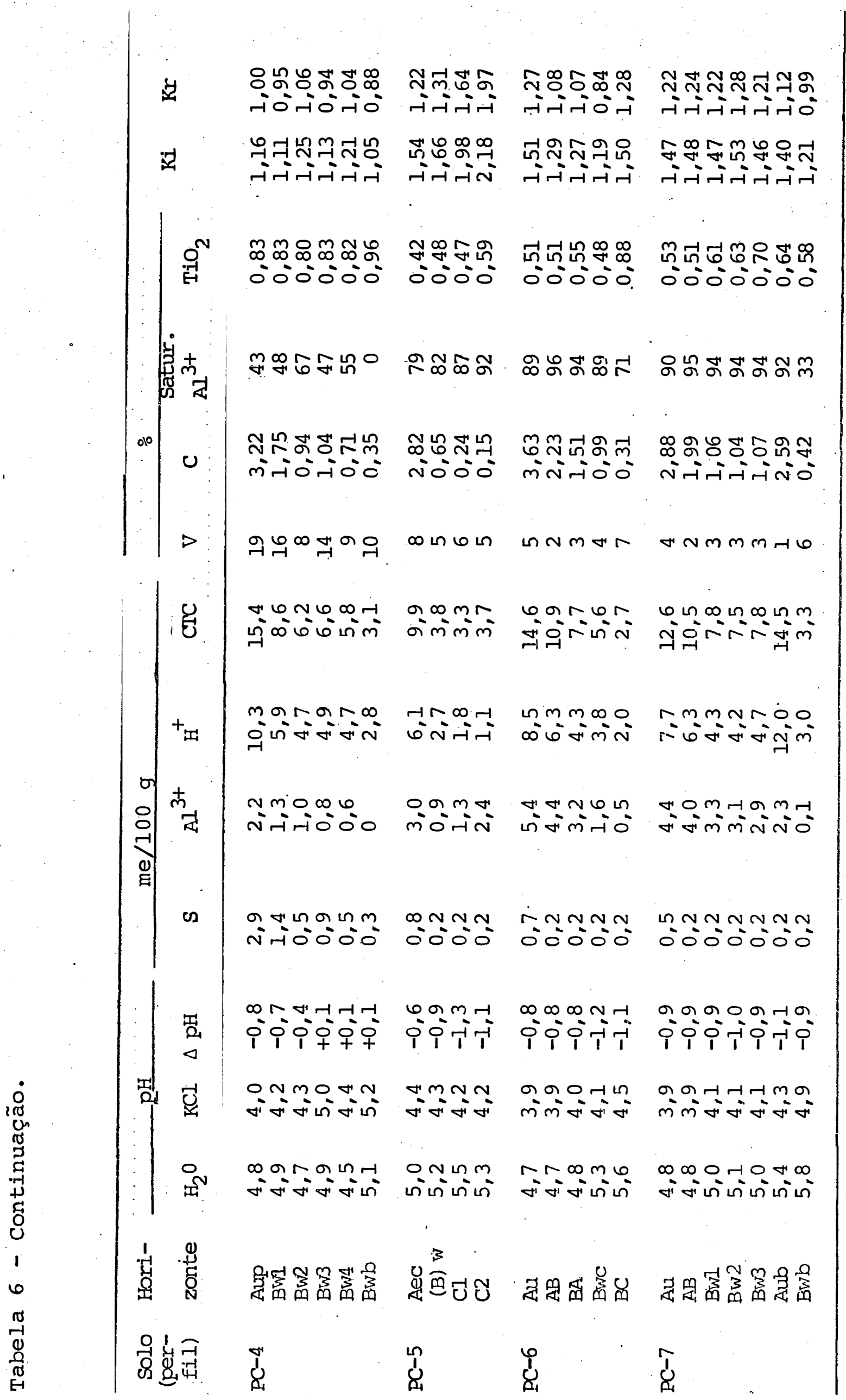




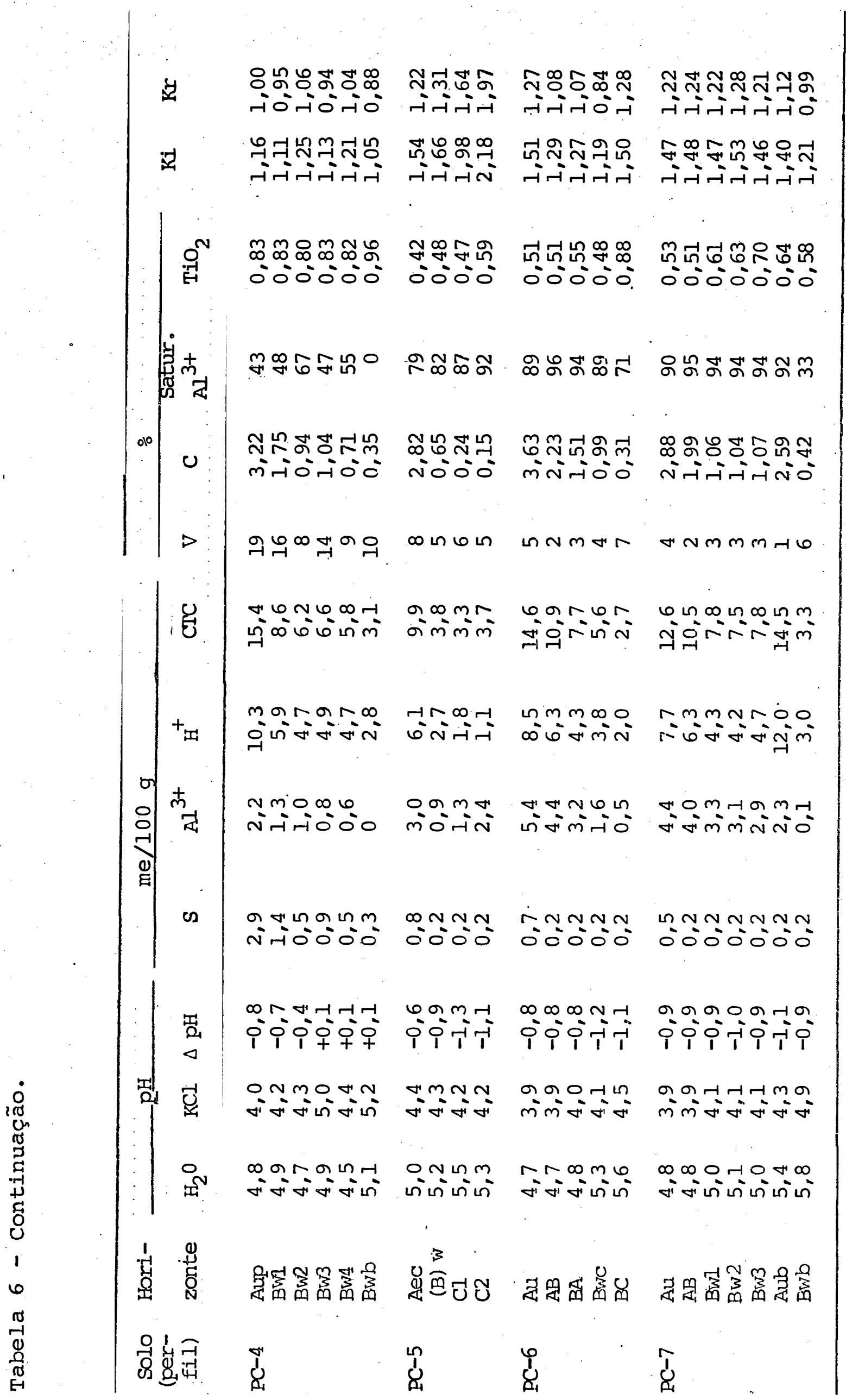



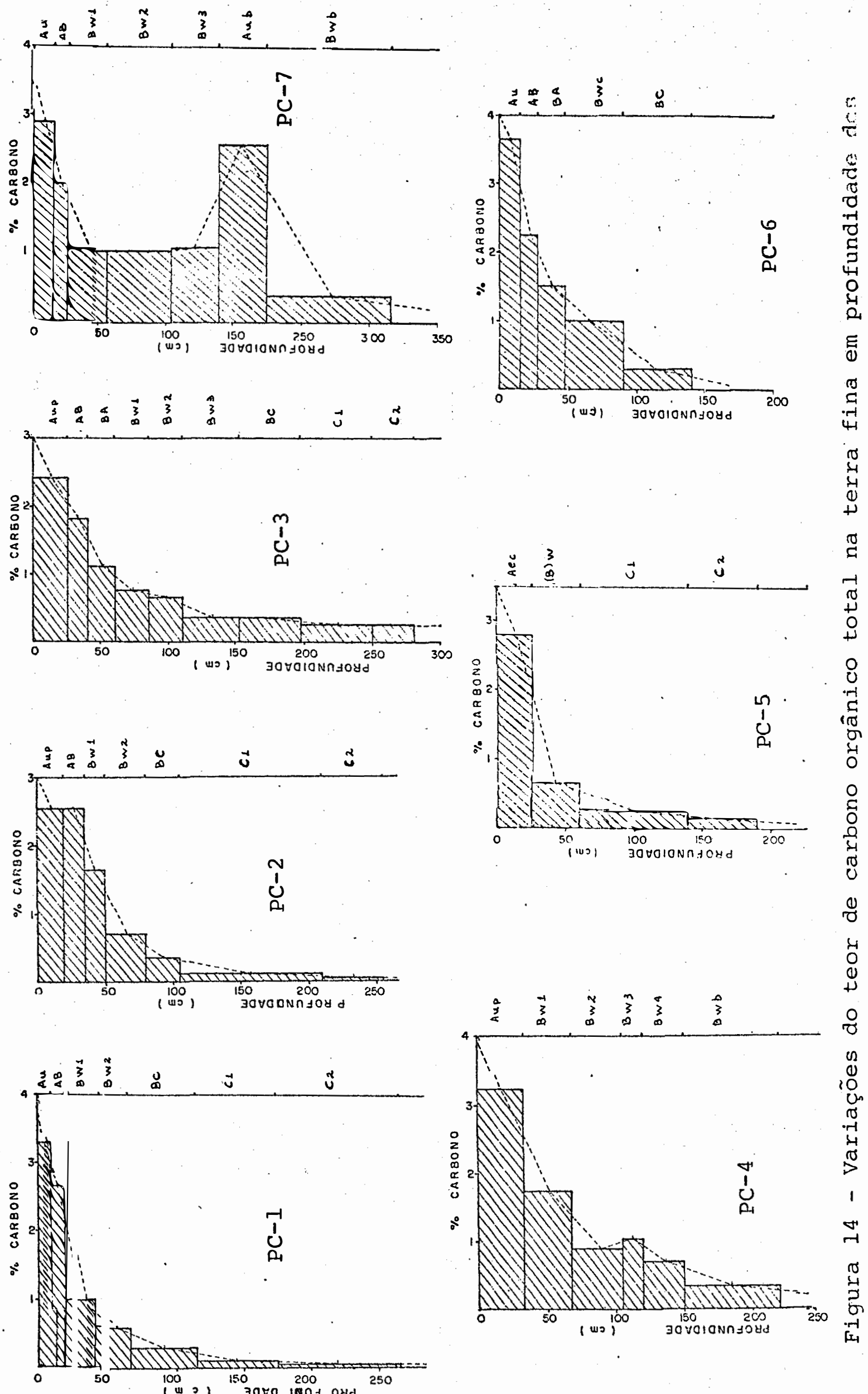

हृ

(4)

प्र $\begin{array}{ll}1 \\ 0\end{array}$

$+\pi$

०) प्र

0 100

un 0

त)

तु

1

$\underset{H}{4}$

$\sigma$
4
0
0
-14 
A altitude acima de $1200 \mathrm{~m}$ condiciona temperaturas amenas durante todo o ano, com mé dia anual em torno de $18^{\circ} \mathrm{C}$, induzindo uma diminuição na atividade biológica. IGNATIEFF e LEMOS (1963) constataram que em altas temperaturas acima de $25^{\circ} \mathrm{C}$ a matérià orgânica é destruida mais rapidamente que em temperaturas maị baixas.

As molēculas orgânicas podem combinar-se com os altos teores de alumínio trocável para formar complexos or gano-metálicos muito estáveis, as quais têm a propriedade de reduzir a ação de enzimas na transformação destes compostos, (BROADBENT et alii, 1964). VOLKOFF e CERRI (1981) observaram em solos do Amazonas a possibilidade de ocorrer a formação de compostos organo-metálicos com o alumínio e consequente fixação de moléculas orgânicas (humina) às argilas através ' dos íons $\mathrm{Al}^{3+}$, proporcionando assim, maior acúmulo de matéria orgânica nos horizontes superficiais. Duchaufour, (1977)citado por LIMA.(1979), tem observado a capacidade de o alumínio formar complexos organo-metálicos muito estáveis. Com relação à distribuição dos teores de carbono nestes perfis parece existir uma certa correlação com os teores de alumínio trocável $\left(\mathrm{Al}^{3+}\right)$. A existência da relação entre os teores de $\mathrm{Al}^{3+}$ trocável e os de matéria orgânica reflete a influência do aluminio na estabilização de compostos orgânicos escuros nos horizontes superficiais e enterrados desses solos. BROADBENT et alii (1964) observaram que solos contendo alofanas (material amorfos) apresentam uma menor taxa de mineralização da matéria orgânica. Isto ocorre pela formação de complexos es táveis com alumínio, de tal maneira que, as enzimas não podem reagir com as moléculas da matēria orgânica, as quais são prẹ servadas de decomposição posterior.

A distribuição da matéria orgânica nos perfis PC-1, PC-2, PC-3, PC-5 e PC-6, Figura 14, caracteriza-sepor apre 
sentar uma diminuição gradual com a profundidade. No perfil PC-4 o decréscimo gradual vai até "o horizcn te BW2, com aumento no horizonte BW3 e diminuição em seguida. No perfil PC-7 o decréscimo que vai até o horizonte Bwl, se mantém, praticamente, constante até o horizonte Bw3, com au mento significativo no horizonte Aub e decrescendo bruscamente no horizonte Birb. No perfil PC-8 também observa-se um aumento acentuado nos teores de carbono na parte mediana do mes mo, decrescendo em seguida (Apêndice I).

Este aumento dos teores de matēria orgânica em horizontes subsuperficiais dos perfis PC-4, PC-7 e PC-8, vem mais uma vez caracterizar a presença de solos enterrados e não processo de iluviação de matéria orgânica, tendo em vista que, na parte superior destes horizontes observa-se a presença de uma linha delgada de concreções lateríticas e bau xíticas, que pode ser evidência de superposição de novo material, considerando-se que os horizontes subjacentes àqueles, com teor elevado de matéria orgânica, são mais alterados que os horizontes sobrejacentes, podendo ser visualizados pelos valores de $\mathrm{Ki}$ e $\mathrm{Kr}$ (Tabela 6 e Apêndice I).

Os valores da relação $\mathrm{C} / \mathrm{N}$ obtidos nos horizontes sucessivos (Apêndice $I$ ), variam de 1 a 15, com valores mé dios no horizonte A (10 a 15), baixos no horizonte B (5 a 11) e muito baixos no horizonte C ( 1 a 6 ), com passagem em geral gradativa dos horizontes superficiais para os mais inferiores.

As características do humus são muito variāveis entre os perfís, sendo que, os horizontes A dos solos são nox malmente pobres em ācidos fúlvicos livires, mas ricos nas frações alcalino-solúveis (ácidos húmicos + ácidos fúlvicos) e humina (Figuras 15 e 16). Enquanto que os horizontes B são em 

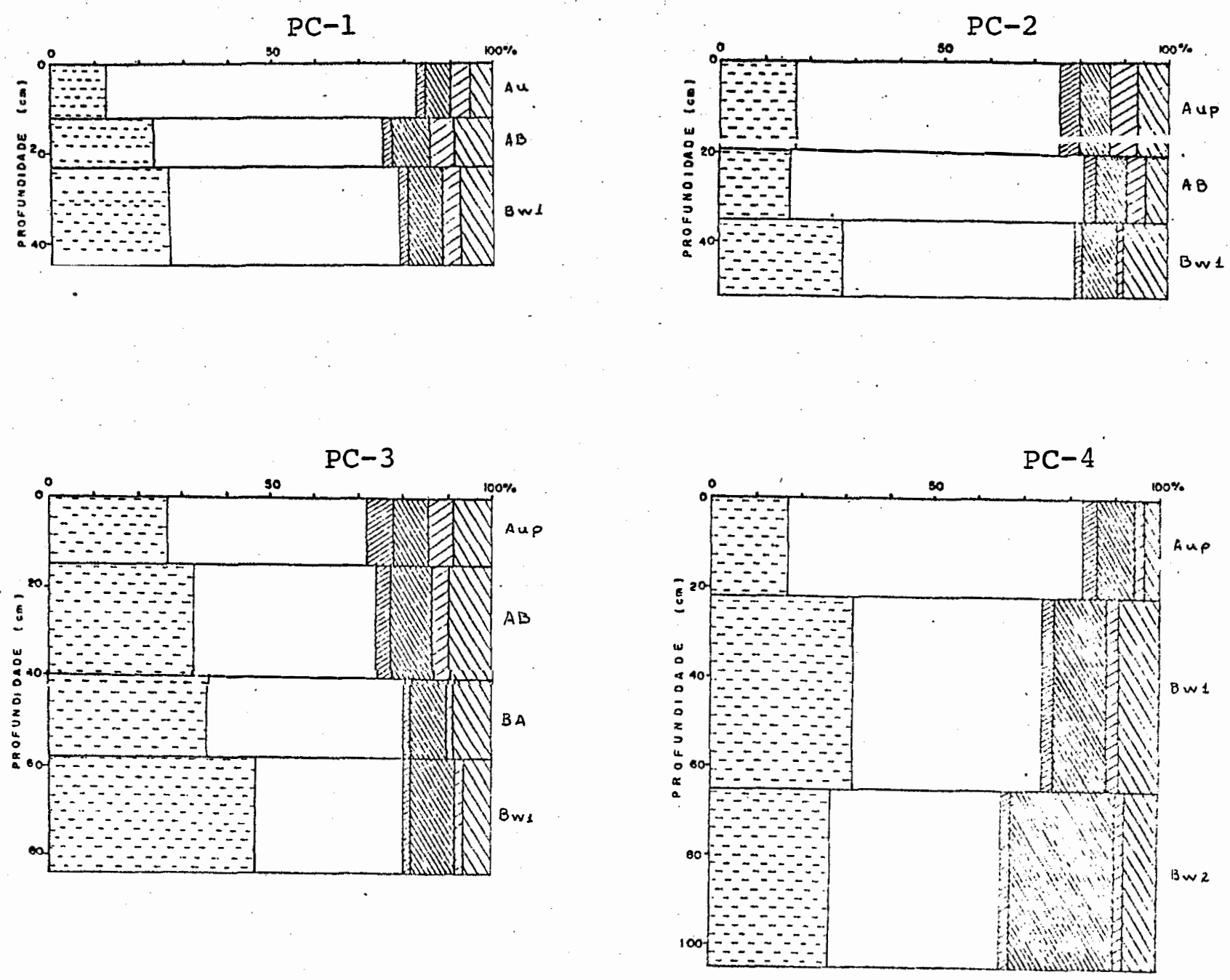

Legenda

$\because$ Ácidos fúlvicos livres.

Ácidos húmicos extraídos pelo pirofosfato.

Ácidos fúlvicos extraídos pelo pirofosfato.

Ãcidos húmicos extraídos pela soda.

Åcidos fúlvicos extraídos peपiiv la soda.

Humina .

Figura 15 - Variações da distribuição do carbono nas frações do humus, em profundidade dos perfis PC-1, PC-2, PC-3 e PC-4 da ârea I. 

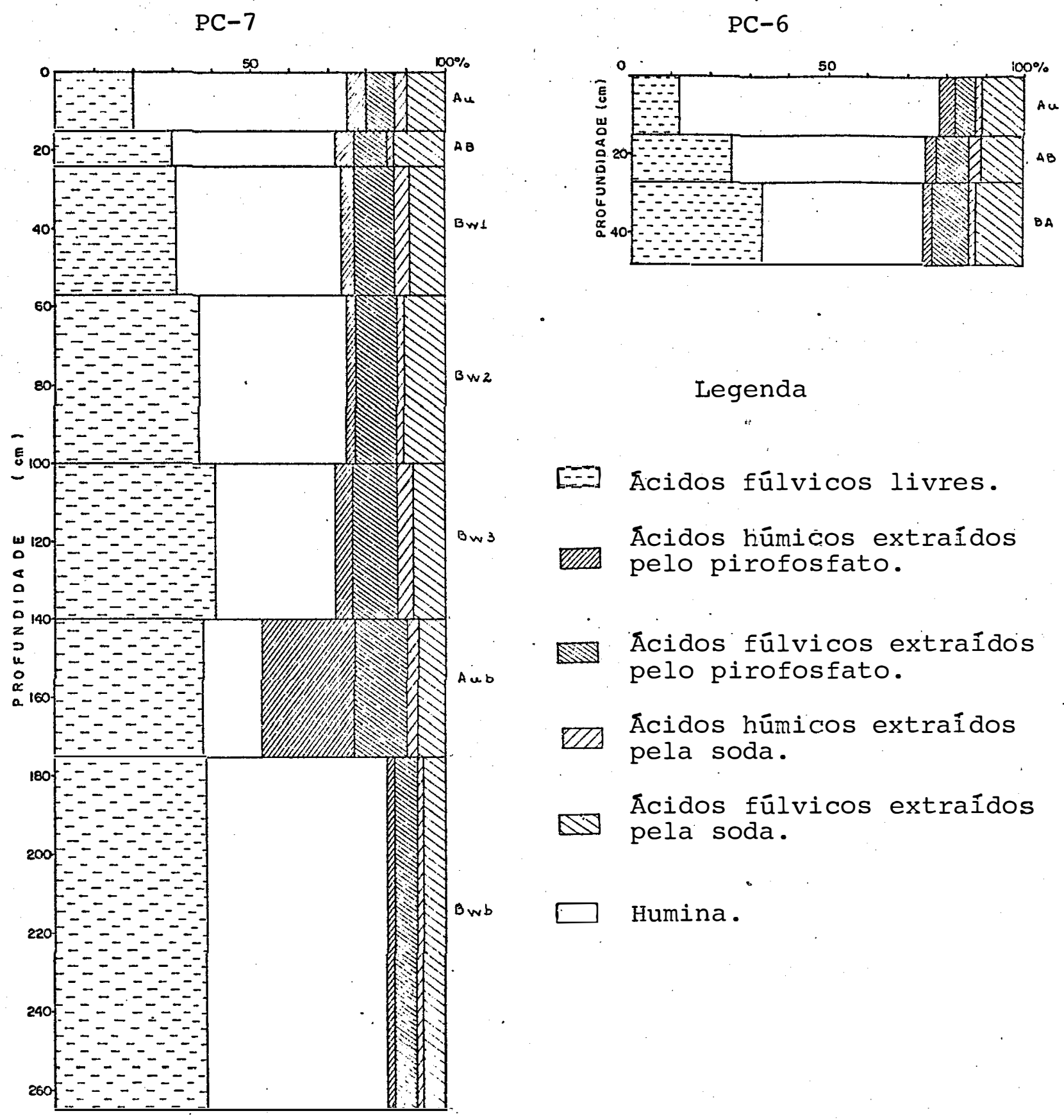

\section{Legenda}

[E] Ácidos fúlvicos livres.

Ácidos húmiços extraídos velo pirofosfato.

Ácidos fúlvicos extraídos pelo pirofosfato.

$\square$

Ácidos húmicos extraídos pela soda.

Ácidos fúlvicos extraídos pela soda.

Humina .

Figura 16 - Variações da distribuição do carbono nas frações do humus, em profundidade dos perfis PC-6 e PC-7 da área II. 
geral mais ricos em ácidos fúlvicos livres e humina e pobres em alcalino-solúveis, com exceção do horizonte Bw2 do perfil PC-4 onde ocorre dominância das frações alcalino-solúveis e humina e do horizonte Aub do perfil PC-7, onde predomina as frações alcalino-solúveis.

Ao observar a composição do humus constata-se que os ácidos fúlvicos livres normalmente aumentam em profun didade, a exceção dos horizontes Bw2 e Aub dos perfis PC-4 e PC-7, respectivamente, como visto anteriormente. A compara ção da composição do humus nas diversas profundidades mostra que quando os ácidos fúlvicos livres aumentam,a humina decres ce em profundidade e vice-versa. A distribuição dos compo nentes do humus destes solos em profundidade apresenta uma certa discordância da observada por VOLKOFF e CERRI (19.81) para solos da Amazonia, que encontraram valores relativamente constantes para humina em profundidade para cada perfil.

As proporções da composição do humus nestes so los são muito variáveis com os ácidos fúlvicos livres varian do no intervalo compreendido entre $12 \%$ a $41 \%$, os alcalinosolúveis de $16 \%$ a $46 \%$ e humina de 76 a $70 \%$ do carbono total (Tabela 7).

Na fração alcalino-solúveis há uma predominân cia dos ácidos fúlvicos em relação aos ácidos húmicos em todos os perfis, com exceção para o horizonte Aub do perfi]. PC-7, onde observa-se a dominância do ácido humico extraído pelo pirofosfato.

A predominância dos äcidos fúlvicos nestes per fis em reląção aos ácidos húmicos, deve-se ao menor peso molecular e maior mobilidade relativa dos primeiros em relação 


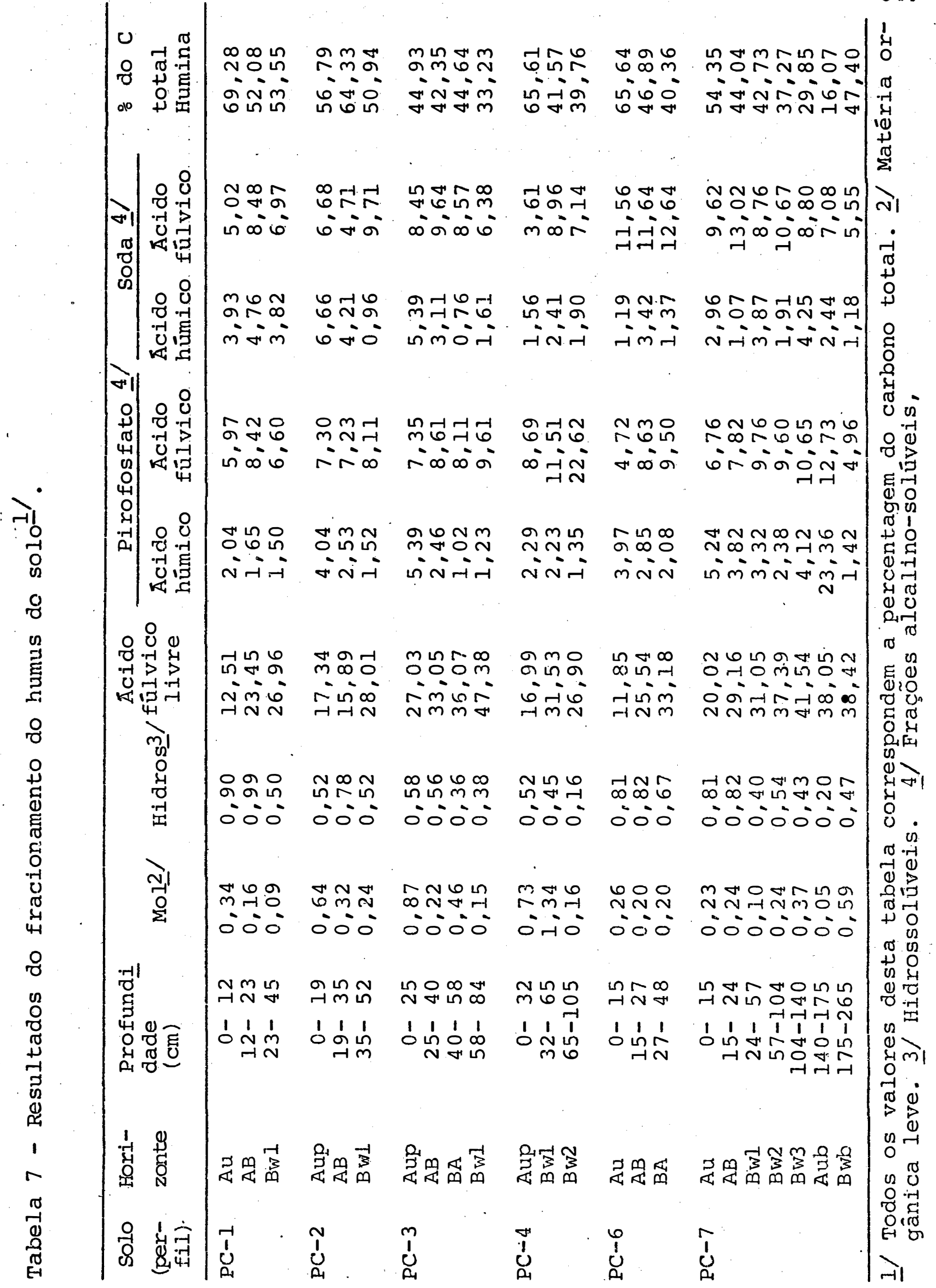


aos segundos, favorecidos pelas condições de excessiva lixiviação predominantes nestes solos. GOH (1980) tem observado que nos solos tropicais onde as condições de lixiviação são excessivas há dominância de ácidos fúlvicos em relação aos ácidos húmicos, concordando com o observado nestes solos.

A dominância de ácidos húmicos em relação aos ácidos fúlvicos na fração dos alcalino-solúveis no horizonte Aub do perfil PC-7, evidencia definitivamente a presença de solo enterrado, tendo em vista que os horizontes sobrejacentes e subjacentes não demonstram haver acumulação de ácidos húmicos. As proporções composicionais deste horizonte Aub ē diferente da do horizonte $A$ deste perfil (PC-7) que pode evidenciar uma ordem diferente ao material orgânico ou cessamento da atividade biótica pelo recobrimento do solo enterrado por outro material.

A concentração do húmus nos horizontes superfí ciais e sua diminuição em profundidade são uma indicação de que as moléculas orgânicas, precursoras das substâncias húmicas permanecem em grande parte na superfície e migram pouco em profundidade. Contudo, ocorre uma evidente penetração de húmus em profundidade, que pode resultar em coloração brunada em alguns horizontes, principalmente dos perfis PC-1, PC-2 e PC-7.

As moléculas constituídas pelos oxi-hidróxidos e argilas, mais solúveis e menos sensiveis às barreiras físico-químicas, seriam as uniücas a penetrarem no solo. Há, assim, uma separação dos precursores para a formação de dois ti pos de humus: um concentrado na superfície e outro difundido em profundidade. Na superfície destes solos há uma concentração na forma de frações alcalino-solúveis e humina e em profundidade são condensadas sob a forma de ácidos fúlvicos livres. A 
distribuição mais uniforme das frações alcalino solúveis, nes tes solos, principalmente, nos perfis PC-4, PC-6 e PC-7, se deve as moléculas que migram durante o período úmido e ao "ama durecerem", se fixam às argilas do solo, durante o período se co. Segundo VOLKOFF e CERRI (1981) as moléculas polimerizadas, podem despolimerizar-se produzindo moléculas pequenas que se movimentam em profundidade onde são novamente polimerizadas, sob condições alternadas de umedecimento e secamento. Esta distribuição está relacionada ao alto teor de umidade destes solos, durante a maior parte do ano, que facilita o movimento das moléculas orgânicas e fixação das mesmas ao solo, durante a estação seca.

A espessura e coloração dos horizontes A destes solos está em parte relacionada à altitude e ao clima ameno reinante no maciço alcalino de Poços de Caldas, e também apre sença de pequenas moléculas orgânicas (humina) que ao penetrarem no solo podem se fixar as argilas pelo ion $A I^{3+}$ ou ser precipitadas pelos oxi-hidróxidos de ferro (VOLKOFF, 1977), permitindo a estabilização da matéria orgânica, nesses hori-zontes e nos horizontes BW3 e Aub dos perfi.s PC-4 e PC-7, res pectivamente, assim como, do perfil PC-8.

TOKASHIRI e WADA (1975) consideram que o alumí nio é um componente essencial na estabilização da matéria orgânica, contra a lixiviação e degradação biótica, não excluin do também a importância do material amorfos (alofanas) na con tribuição à estabilidade. Isto pode em parte ser comprovado pelos valores relativamente altos de alumínio extraído pelo citrato-bicarbonato-ditionito (CBD) (Tabela 9) e material amor fo (Tabela 14).

A estabilização da matêria orgânica pela formą ção de complexos de matéria orgânica-argila e matéria orgânica-metal-argila promove e contribui para a agregação do solo, levando a um melhoramento das propriedades físicas. 


\subsubsection{Complexo sortivo e $\mathrm{pH}$}

Em relação ao pH, os dados obtidos (Tabela 6 ) mostram que estes solos são fortemente a moderadamente ácidos. Os valores de $\mathrm{pH}$ de maneira geral apresentam uma tendência em aumentar com a profundidade. Esta observação, porém, não é válida para os perfis PC-2 e PC-3, que apresentam valores de pH diminuindo dos horizontes superficiais até a parte média do perfil e em seguida passam a aumentar com a profundidade. Tal fato se deve à aplicação rotineira de calcário, nas áreas ocupadas por tais solos.

Verifica-se (Tabela 6) que os valores mais bai xos de $\mathrm{pH}$ na superfície do solo, estão relacionados principal mente à dissociação do $\mathrm{H}^{+}$dos grupos carboxilicos da matéria orgânica.

Os dados de $\mathrm{pH}$ obtidos pelas medidas feitas em suspensão com KCl apresentam uma distribuição semelhantes aos determinados em ägua nos perfis $\mathrm{PC}-1, \mathrm{PC}-2, \mathrm{PC}-4, \mathrm{PC}-5, \mathrm{PC}-6$ e PC-7, somente com os valores absolutos diferentes. Já no perfil PC-3 ocorre um aumento do valor de $\mathrm{pH}-\mathrm{KCl}$ em profundidade até a parte média do perfil (horizonte Bw2) decrescendo em seguida. Os dados de $\mathrm{pH}$ podem evidenciar diferenças entre os solos, dependendo do sinal e magnitude do $\Delta \mathrm{pH}$. De acordo com MEKARU e UEHARA (1972) e VAN RAIJ e PEECH (1972) quando o $\triangle \mathrm{pH}\left(\mathrm{pH} \mathrm{KCl}-\mathrm{pH} \mathrm{H}_{2} 0\right)$ é negativo, significa que o solo tem uma carga líquida negativa e quando o $\Delta \mathrm{pH}$ é positivo a carga lỉquida do solo é positiva.

Nos perfis $\mathrm{PC}-1, \mathrm{PC}-2, \mathrm{PC}-5, \mathrm{PC}-6$ e PC-7 há uma predominância de carga líquida neqativa, baseadas nos valores de $\triangle \mathrm{pH}$, enquanto que nos perfis PC-3 e PC-4, nota-se a 
presença de carga líquida positiva nos horizontes Bw2, Bw3 e BC, respectivamente, em razão destes solos apresentarem complexo coloidal dominado por caulinita e óxidos de $\mathrm{Fe}$ e Al, que exibem, normalmente, cargas elētricas variáveis com $\circ \mathrm{pH}$.

Os valores do $\Delta \mathrm{pH}$ negativos de pequena magnitude em torno ou inferior a unidade, para todos os perfis estudadism aliados aos valores positivos, demonstram um àvançado grau de intemperismo. No caso particular do PC-l e mais especificamente O PC-2, ambos solos caracterizados preliminarmente como contendo horızonte câmbico, mais uma vez vem comprovar a não definição deste horizonte diagnóstico. Tais valores de $\Delta \mathrm{pH}$ são semelhantes para solos oxídicos.

A soma de bases trocáveis ( $S$ ), a capacidade de troca de cátions (CTC) a pH 7 e a saturação de bases (V \%) (Ta bela 6) são baixos, com valores mais altos nos horizontes superficiais, decrescendo com a profundidade. A distribui.ção dos resultados nos perfis sugere uma grande associação entre a CTC e o conteúdo de matëria orgânica, tendo em vista que, a mesma apresenta distribuição semelhante ao longo dos perfis. Os resultados mais elevados de $\mathrm{S}$, СTC e $\mathrm{V}$ \% nos horizontes super ficiais dos solos da área I (perfis PC-1, PC-2, PC-3 e PC-4) em relação a área II (perfis PC-5, PC-6 e PC-7), com teores se melhantes de matéria orgânica, deve-se a contribuição de corretivos e fertilizantes aplicados a estes solos durante o uso agrícola.

Acidez trocável é representada pelos íonshidro gênio e alumínio. Os teores de $\mathrm{Al}^{3+}$ trocável e $\mathrm{H}^{+}$titulável a $\mathrm{pH} 7$, variam respectivamente de 0 (zero) a $8,4 \mathrm{me} / 100 \mathrm{~g}$ de so lo e 0,6 a 10,6 me/100 $\mathrm{g}$ de solo (Tabela 6), sendo também, normalmente mais altos na superfície, decrescendo com a profundi dade, com exceção feita aos perfis PC-1 e PC-2, onde os teores de alumínio crescem com a profundidade. Tal fato parece estar 
relacionado a remoção de algum aluminio não trocável pelo $\mathrm{KCl}$. $1 \mathrm{~N}$. De acordo com AMEDEE e PECH (1976) pelo menos uma certa quantidade de alumínio extraido $\mathrm{com} \mathrm{KCl}$ lN, vem da solubilização de alumínio amorfos. Outro fator que deve ser considerado é a presença de material (mineral) instável ao pH do solo, res ponsável pela grande liberação de alumínio principalmente nos solos referentes aos perfis PC-1 e PC-2.

Os valores baixos de soma e saturação de bases, aliados ao $\mathrm{pH}$ ácido destes solos, contribuem para um aumento de ions de $\mathrm{Al}^{3+} \mathrm{e}^{+}$ocuparem as cargas negativas do complexo coloidal. Os teores de $\mathrm{Al}^{3+}$ trocável, superiores à soma de ba ses, conferem aos perfis em geral uma elevada saturação desse elemento, imprimindo aos solos um forte carater álico. Quanto ao perfil PC-3, o mesmo seria distrófico, considerando que a saturação com $\mathrm{Al}^{3+}$, no horizonte $\mathrm{B}$, não é superior a $50 \%$.

Os resultados químicos obtidos nestes solos evi denciam uma fertilidade natural baixa e níveis tóxicos eleva dos de Al trocável.

A СТC efetiva nestes solos está intimamente relacionada ao conteúdo e a natureza da fração argila. Seus valores são extremamente variáveis, de 0,4 a 16,7 me/100 g de argila (Tabela 8), com valores mais elevados nos horizontes inferiores dos perfis PC-1 e PC-2, devido provavelmente à presença de mine rais com carga negativa permanente.

A matéria orgânica do solo contribui substancial mente à capacidade de troca de cátions total do solo, que segundo Van Dijk (1.971) citado por GOH (1980), chega a contribuir com 25 a 90 \% do total da CTC de horizontes superficiais de so los minerais. A contribuição da matēria orgânica estimada pe- 


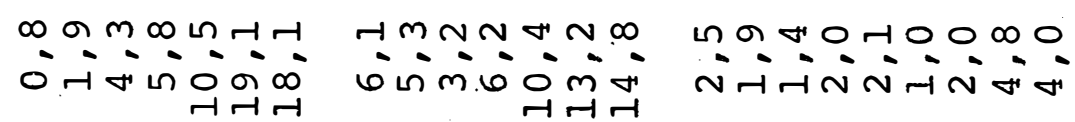
它要

भौ

व.न minann 4유 유

O

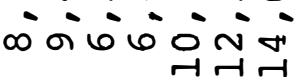

batrmamnat

ध $+1$

人ष

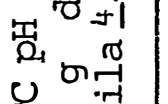

HRGOaN

HAnmLno

걷얻ำ

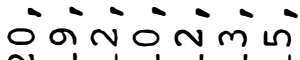

H约

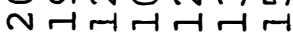

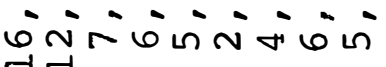

엉유 엄

ro 8

mil

'U

य.

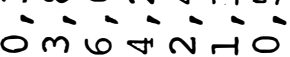

0 मबनमत

oथ

$N-1$

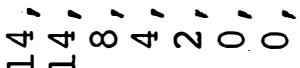

लं०

.

नr

तr

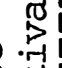

लो

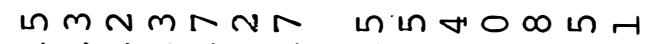
Nंம்

$m h H \in A N N$ No

嵌

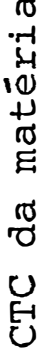

II

on

$\sim \circ$

Hen $00, \pi$

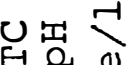

பंनंம்

mL TOLMN

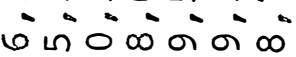

$\rightarrow-1$

$\neg-1$

OL $006 \mathrm{manO}$

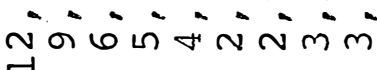

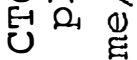

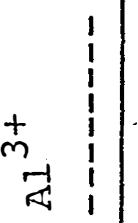

- Hतa

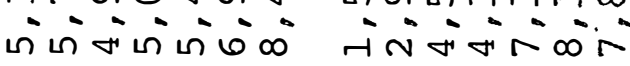

$\ln \pi \pi^{2}$

into

r.

intand

4h000000

윰Nㅐ

$U$ O $010^{\circ}$

mol $m^{-1} 0$

in mormoo

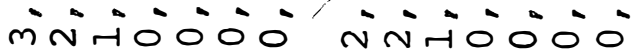

vedarainta Rrongmmin Nitió00

10

द्य ट

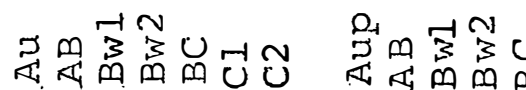

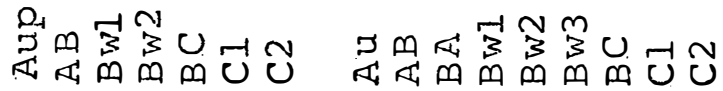

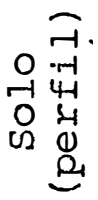

-1
1
0
01

$\bigcup_{1}^{\prime}$
$\tilde{n}_{4}$

$\hat{u}_{0}^{m}$ 


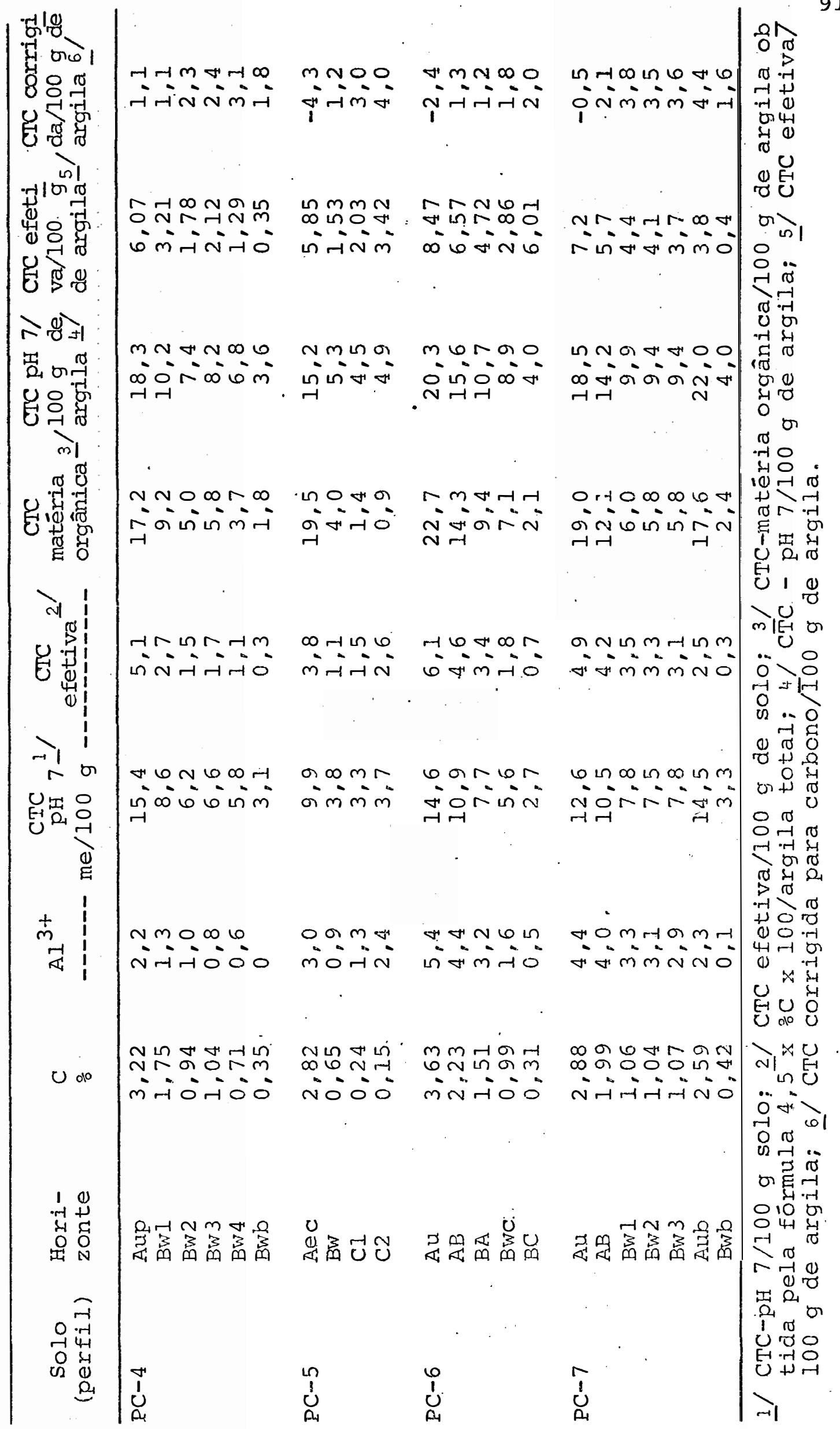


lo método gráfico proposto por BENNEMA (1966) não pode ser aplicado a tedos estes solos (Figura 17), devido não se observar boa correlação entre os teores de matéria orgânica (carbono)e os de CTC/lo0g de argila, principalmente nos perfis PC-1, PC-2, PC-3, PC-4 e PC-7.

A contribuição da matéria orgânica à CTC nos horizontes superficiais calculada pela fórmula: $4,5 \times$ × C x 100/argila total; compreende valores de 9,2 a 22,7 me/100 g de argi la; em alguns horizontes são superiores ao da CTC total do so 1o, evidenciando a presença de natéria orgânica com CTC mais baixa que a estimada pela fórmula, uma vez que os valores estimados superam os 90 \% da CTC total do solo.

A СТC corrigida (Tabela 8) apresenta valores normalmente baixos na maior parte dos perfis, com exceção dos horizontes inferiores dos perfis PC-1 e PC-2, evidenciando, portanto a dominância de argila de baixa atividade.

\subsubsection{Relação Ki e Kr}

Os valores da relaçăo moleculares $\mathrm{Ki}$ e $\mathrm{Kr}$ (Ta bela 6) variam nestes solos respectivamente de 1,05 a 2,44 e de 0,84 a 2,14. Considerando-se os valores destas relações estes solos são muito alterados. Dentre eles os mais intempe rizados seriam os correspondentes aos perfis PC-3 e PC-4, com valores de Ki entre 1,05 e 1,39, enquanto que os perfis PC-1 e PC-2, seriam os menos intemperizados. com valores de 1,57 a 2,44, com os demais perfis estando em situação intermediária.

Além deste fato os valores das relações molecu lares dos perfis PC-3, PC-4 e PC-7, principalmente a partir dos horizontes B'w2, Bw3 e Bwb respectivamente, são ligeiramen 

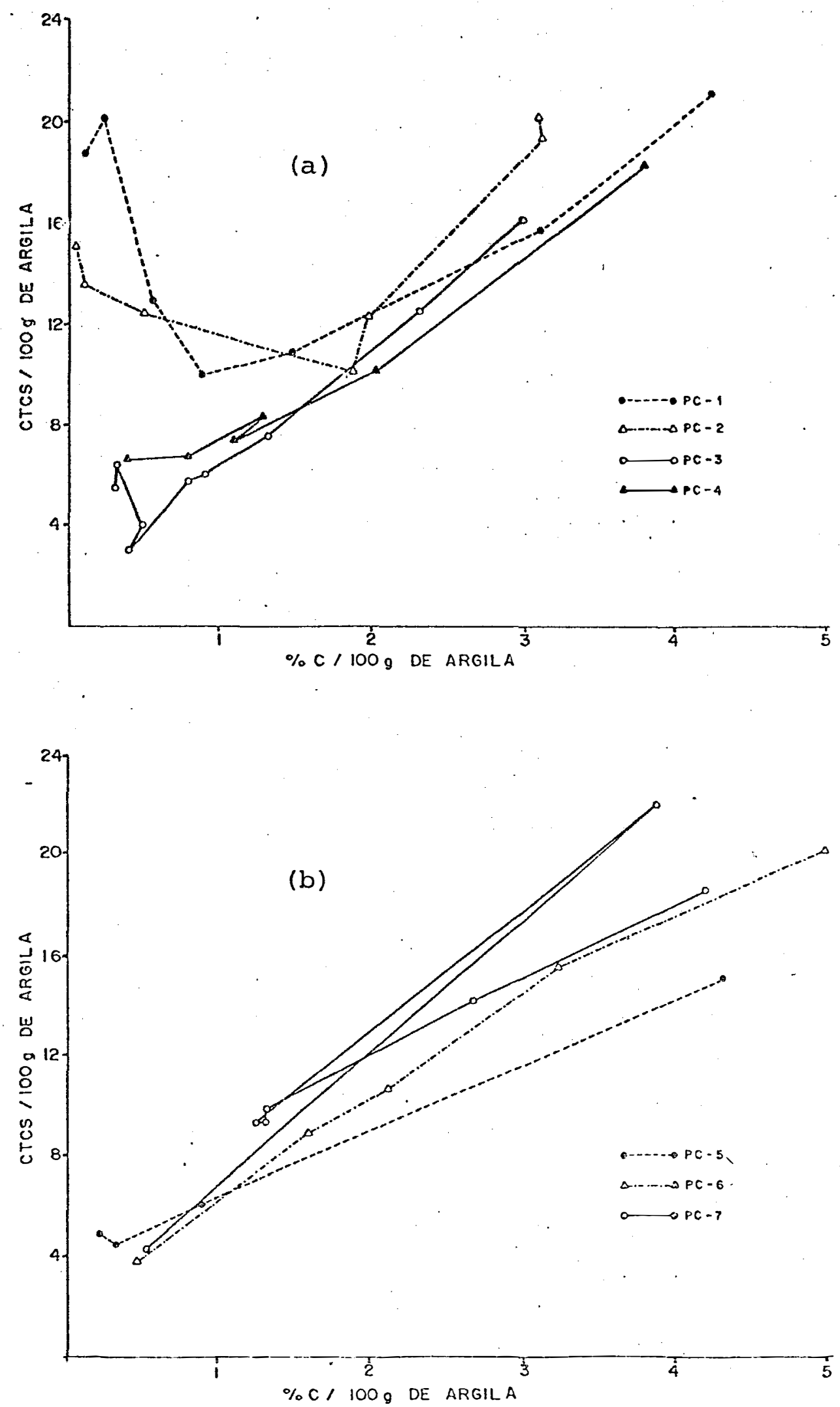

Figura 17 - Representação gráfica da contribuição da matēria orgânica na CTC do solo: (a) referente aos perfis PC-1, PC-2, PC-3 e PC-4 da áre $I_{;}$(b) correspondente aos perfis PC-5, PC-6 e PC-7 da área II. 
te inferiores aos horizontes acima, evidenciando a presença de material do solo mais alterado.

Os valores de titanio, além de serem baixos, são variāveis em profundidade, o que vem demonstrar uma certa homogeneidade no material de partida. Os perfis PC-4 e PC-7 apresentam quebra nesta homogeneidade ilustrando novamente a ocorrência de paleossolos.

\subsubsection{Balanço de cargas}

A distribuição de cargas nos solos estudados, de terminados pela adsorção de $\mathrm{K}^{+}$e $\mathrm{Cl}^{-}$do $\mathrm{KCl}$, são apresentados na Tabela 9. Estes resultados mostram adsorção simultanea não só de cátions como de ânions e como tal indicam a coexistência de cargas elétricas negativas e positivas nos solos. A carga líquida negativa está presente em todos os perfis, enquanto que carga líquida positiva ocorre nos horizontes BW2, BW3 e BC do perfil PC-3, no horizonte BC do perfil PC-6 e no horizonte Bwb dos perfis PC-4 e PC-7.

Os valores de carga negativa são mais expres sivos nos perfis PC-1 e PC-2 e nos horizontes superficiais dos demais solos. A diferença marcante nos valores de carga negativa está relacionada principalmente no contẹúdo de matéria or gânica mais elevada nos horizontes superficiais que nos inferio res. De acordo com VAN RAIJ e PEECH (1972) e MORAIS et alii (1975) a matéria orgânica seria a principal contribuinte para carga elétrica negativa dos solos de regiões tropicias.

A magnitude das cargas negativas observadas nos perfis PC-1, PC-2 e PC-5, não estaria relacionada.somente à ma téria orgânica, tendo em vista que, o conteúdo da mesma decres 
1

यू

N N N

N $\sim-1$

ननम्नत्म

ननतN

in $\forall 0$

⿰纟.

$\infty 0$ o $\infty$ in

O

бก

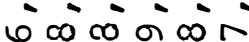

nininió

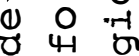

प 10

थ $\stackrel{2}{\circ}$

मे

O

(1) $\pi$ 亗

.

के

त $\begin{array}{ll}+ & 0 \\ -\pi & 0\end{array}$

-

(1)

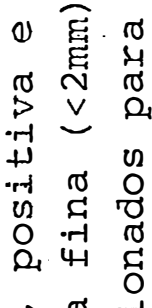

ช

$>$ मे

-r 0 1)

ro 0

or 0

(1) 300

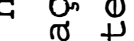

थ मे

ती $4 \mathrm{H}$

- 0 r

मे $\mathrm{C}$ पे

iu $\sim$ -

त)

v $\stackrel{0}{0}$ O

ต ${ }^{m}$ r

मे 0 .

U मा हा

1

a

జ)

on ma

rरा

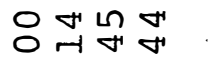

in 6 \%

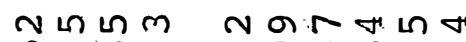
ก $6 \mathrm{mo}$ म

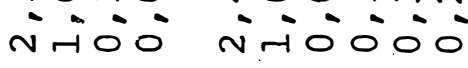

NIn

mें

$m$
$m$
$m$ i

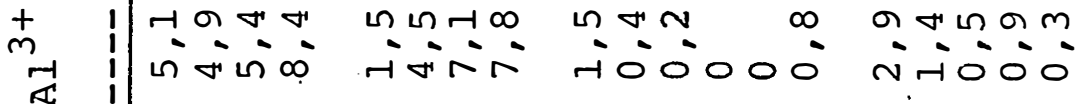

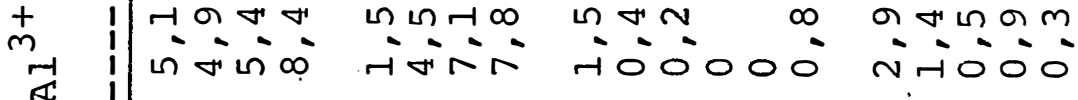

$m$
$m$
$m$ i

य

娒

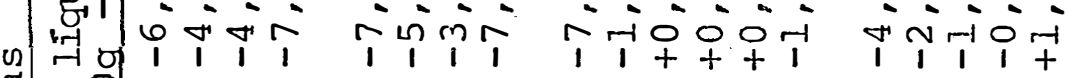

$\sigma \infty \backsim m$

mनाN

$N \rightarrow \infty \infty$

ar $m \infty m a$

I HN 60

$\rightarrow m \rightarrow 0$

a $m \sim \infty$

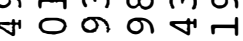

iñN

i $t+t+t+t+t+t+t+t+t+t$

3 N 0 - $\rightarrow$

नु

in

mNON

$\sigma \infty N N$

$-10$

$4 N \cos$

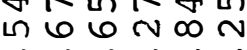

4ब

(1) $\infty$ i

ก 6 \% -...

$\infty \pi m m i n i$

$N-\operatorname{rm} \infty$

- n.

歪

6rom NR⿻

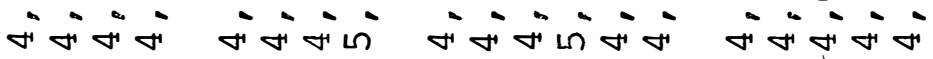

证

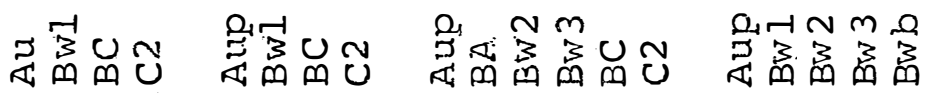

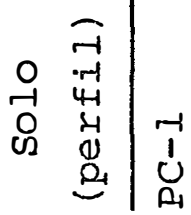

U

$\bigcup_{n_{1}}^{m}$

$n$
0
1 


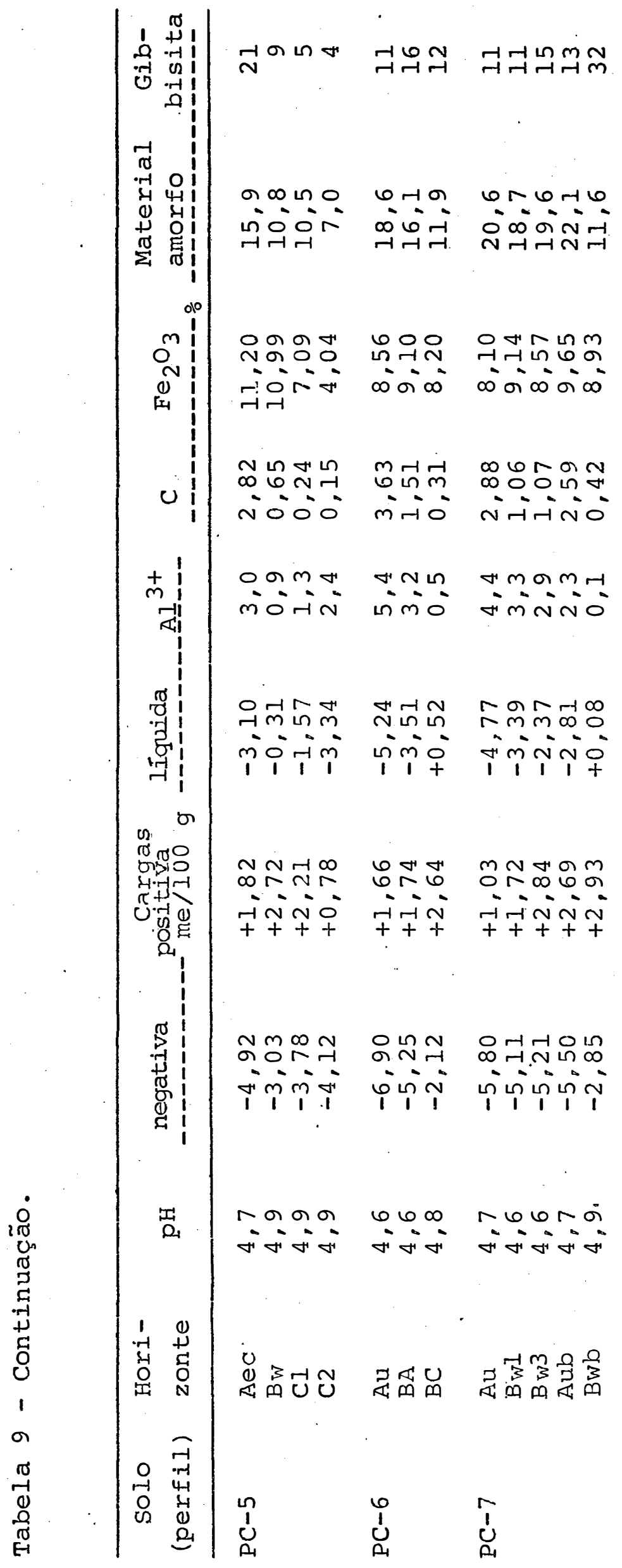


ce em profundidade, não sendo observado a mesma tendência para as cargas. Tal fato pode ser atribuido à presença nestes solos de mineral que possua superfície de carga negativa permanete. Segundo VAN RAIJ e PEECH (1.972) e KENG e UEHARA (1974) os colóides do solo que apresentam superfície de carga negatí va permanente são os minerais de argila do tipo 2:1. Nestes solos a presença de carga negativa permanente pode ser atribui "da aos minerais micaceos na fração argila.

A presença de cargas positivas nestes solos po de ser atribuida aos óxidos e hidróxidos de $\mathrm{Fe}, \mathrm{Al}, \mathrm{Ti}, \mathrm{Mn}$, caulinita e alofana (material amorfos) que apresentam cargas dependentes de pH. De acordo com VAN RAIJ e PEECH (1972) e KENG e UEHARA (1974) são tais óxidos e caulinita, quartzo e sílica amorfa, os minerais do solo que apresentam carga super ficial variável. Como nestes solos há presença desses minerais, talvez com exceção de sillica amorfa, na sua composição mineralógica, estaria assim explicado a presença de carga positiva nos mesmos. Os valores de $\mathrm{pH}$ na determinação das cargas elétricas considerados relativamente baixos, permitiu a estes solos exibirem as cargas positivas. De acordo com PARFITT (1980) os öxidos e hidróxidos de Fe e Al, carregam mais cargas positivas em valores baixos de pH. Enquanto que, GALLEZ et alii (1976) admitem que o total das cargas de superfície da caulini ta e dos óxidos e hidróxidos de $\mathrm{Fe}$ e $\mathrm{Al}$, não depende só do pH, mas tambēm, da natureza e concentração dos eletrólitos na solução do solo.

O efeito do $\mathrm{pH}$ nas cargas positivas e negati vas dos solos é provavelmente devido aos mecanismos de trans-. ferência de prótons na matéria orgânica, óxidos de ferro e aluminio e margens de caulinita (PARKS, 1967; CASHEN, 1968 e HINGSTON et alii, 1972). 
Nestes solos é muito provável ter havido influência do pH e concentração dos eletrolitos na determinação de suas características de cargas.

A carga líquida foi obtida pela diferença entre. a carga negativa e a carga positiva, determinada em $\mathrm{KCl}$ $0,1 \mathrm{~N}$. A carga líquida nestes solos parece relacionar-se às diferenças de matéria orgânica, argila e óxidos e hidróxidos de ferro e alumínio. A carga líquida positiva observada nos perfis PC-3, PC-4, PC-6 e PC-7, estaria relacionada aos teores mais elevados de gibbsita nos horizontes desses perfis. Enquanto que a magnitude da carga líquida negativa refere-se à presença de matéria orgânica nos horizontes superficiais e possivelmente ao conteúdo de mica na fração argila, de modo que seu comportamento a este respeito, corresponde a um colói de do tipo carga permanerte nos horizontes subsuperficiais on de os conteúdos de matéria orgânica são baixos. MEKARU e UEHA RA (1972) estudando solos do Havai aventaram a possibilidade da mica na fração argila apresentar comportamente semelhante aos colóides de carga permanente, para explicar a presença de cargas negativas em valores baixos de $\mathrm{pH}$.

Os valores de PCZ e de carga elétrica líquida dos solos, determinados por titulação potenciométrica, tendo como solução eletrolítica de equilíbrio o $\mathrm{KCl}$, são mostrados na Tabela 10 e Figuras 18 e 19. Os valores de PCZ dos hori zontes A e B dos perfis $\mathrm{PC}-1$ e $\mathrm{PC}-2$ são 3,7 e 3,5, respectiva mente, enquanto que, nos demais perfis estes valores são mais altos no horizonte $B$ que no horizonte A. Nos perfis $P C-1$, PC-2, PC-6 e PC-7 observa-se uma pequena diferença nos valo res de PCZ entre estes solos e horizontes, os quais variam de 3,4 a 3,7. Esta pequena diferença do PCZ entre os horizontes $A$ e $B$ destes perfis pode ser atribuido à presença de mineral que comporte-se como colóide de carga negativa permanente. 


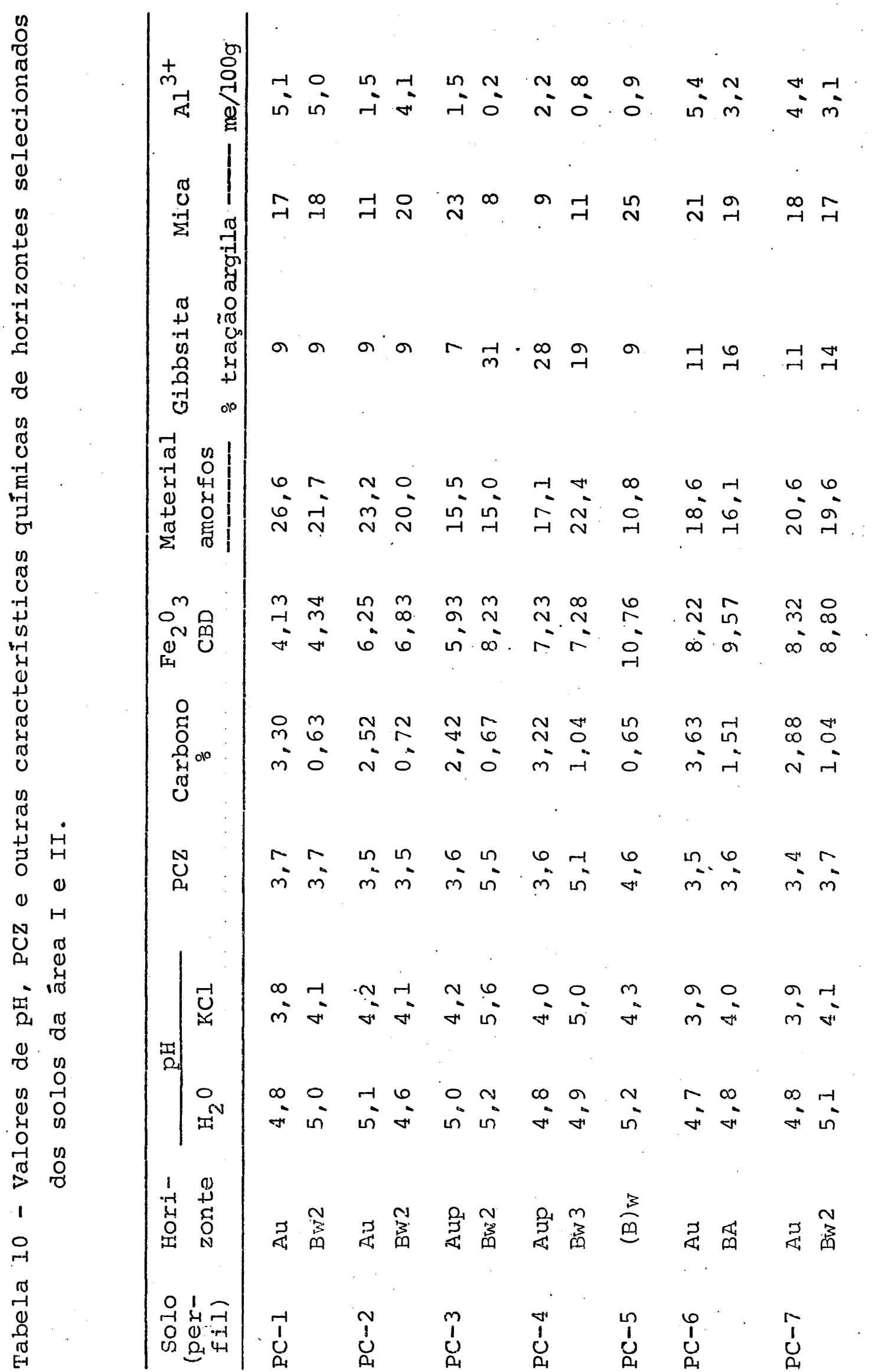




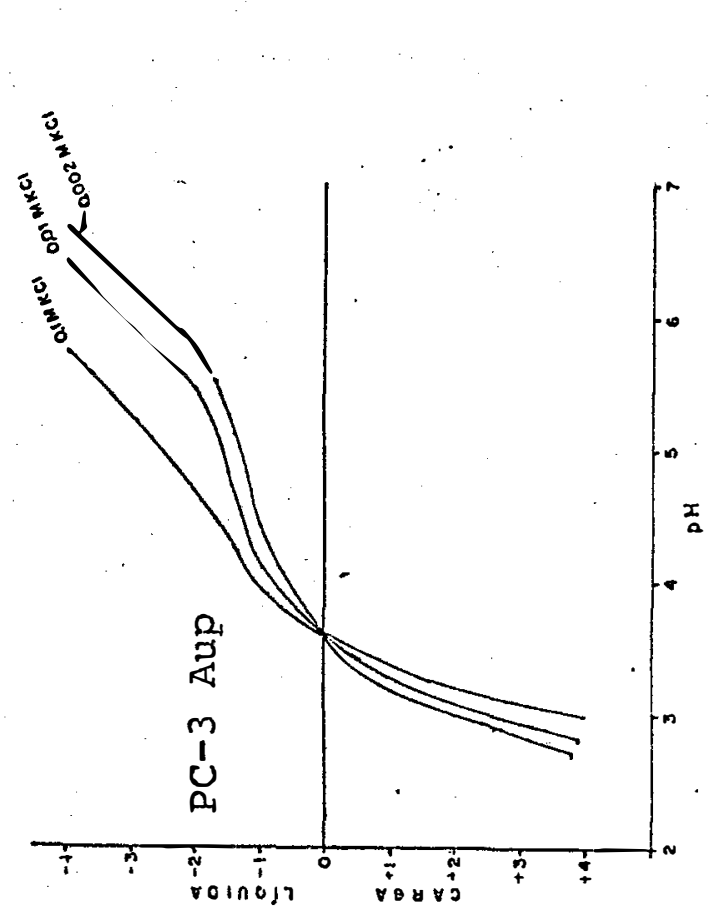

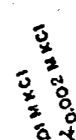
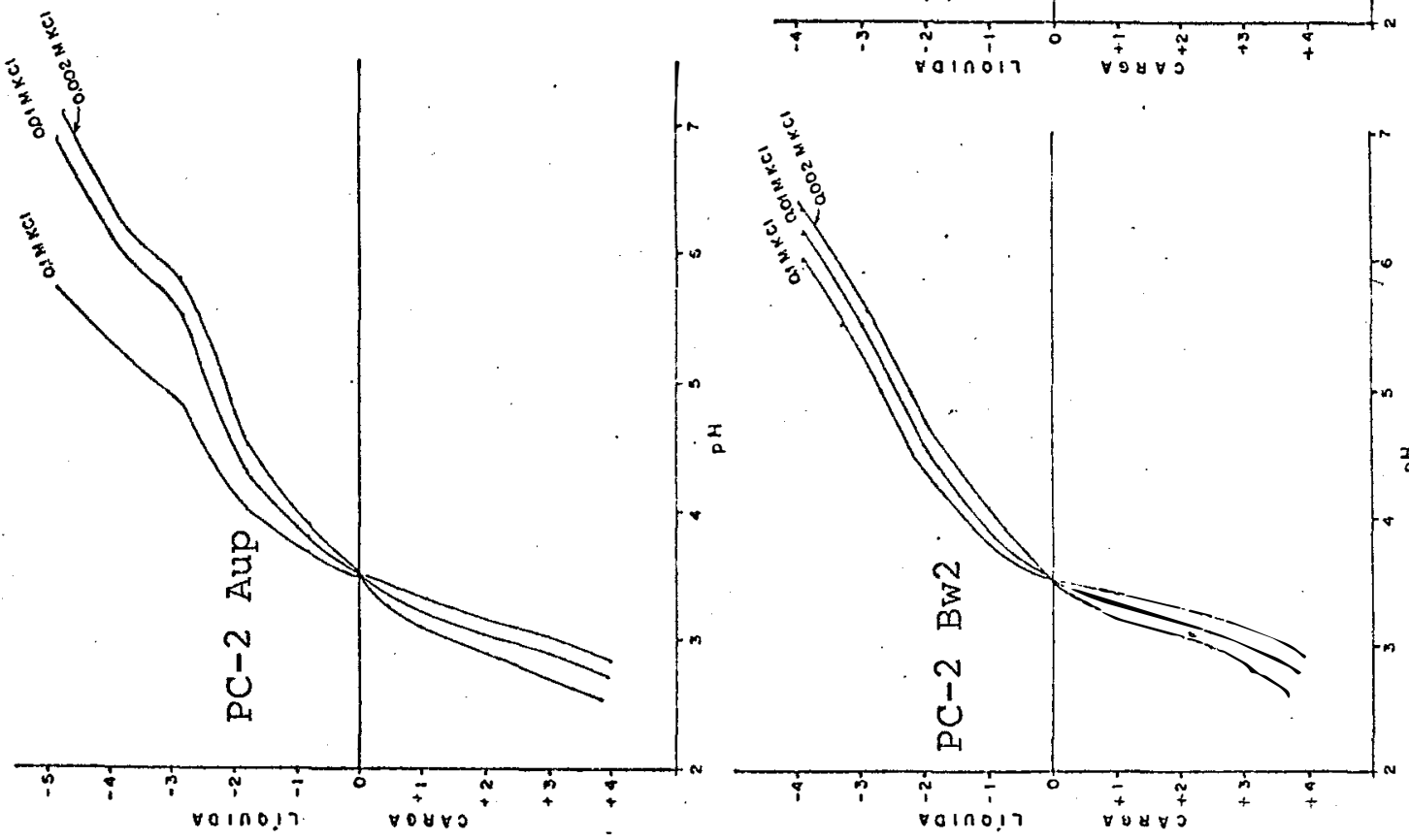

100.
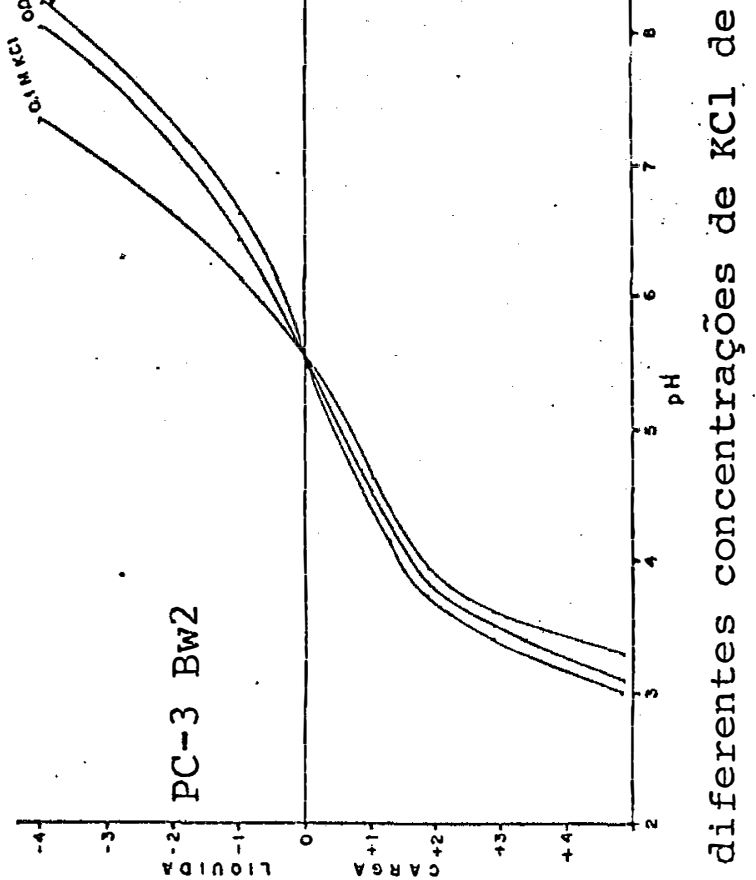

U

잉 0

$\begin{array}{ll}0 & 1 \\ 20 & 0\end{array}$

un

$\overbrace{4-1}^{5}-i$

첨

- 02

त्र

क्ष

$\begin{array}{ll}-1 & 0 \\ 0 & 0\end{array}$

ช

芹
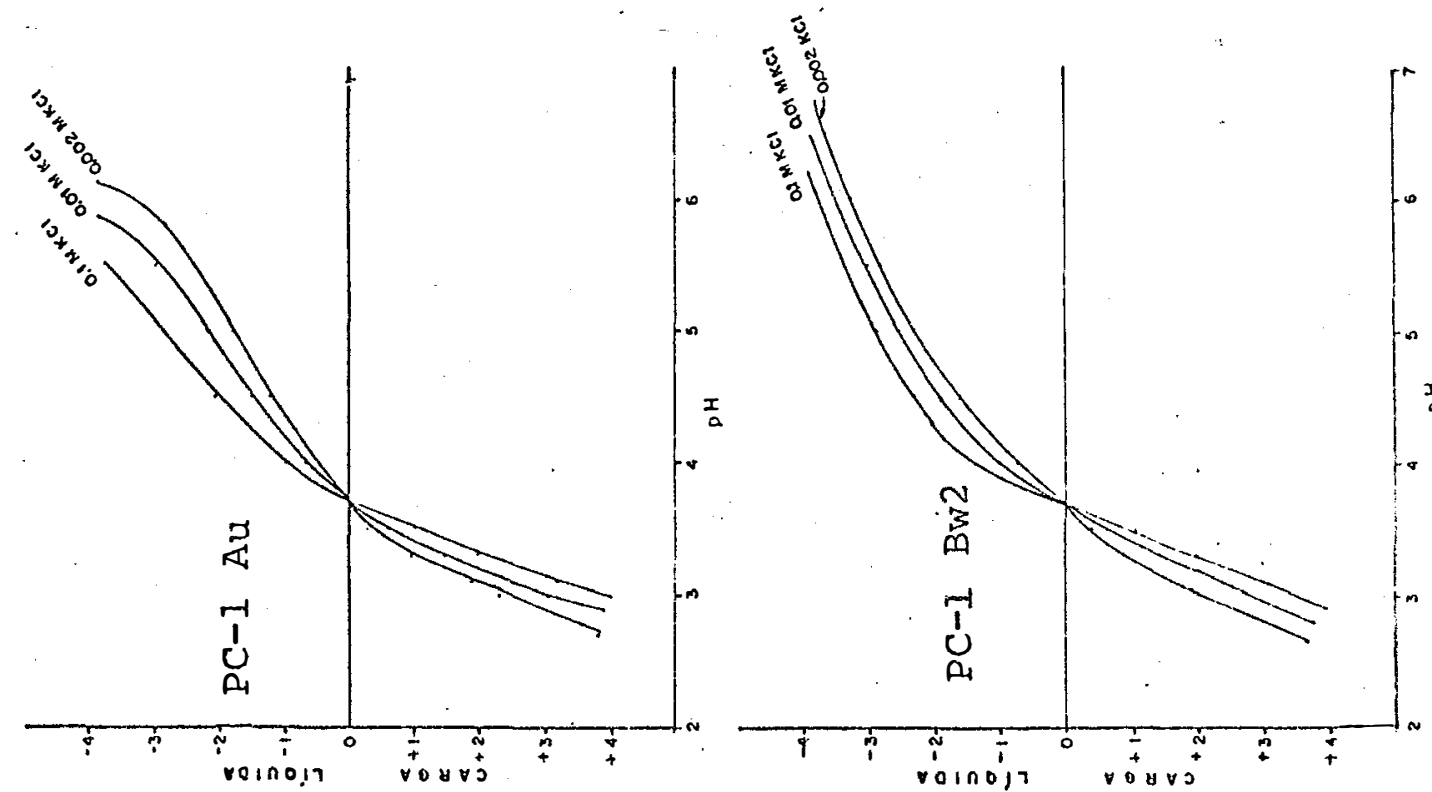

U 4

$\pi$

$0+$

$2 \pi$

的

r

4
$>$

$\begin{array}{ll}x & 1\end{array}$

$\infty$ 

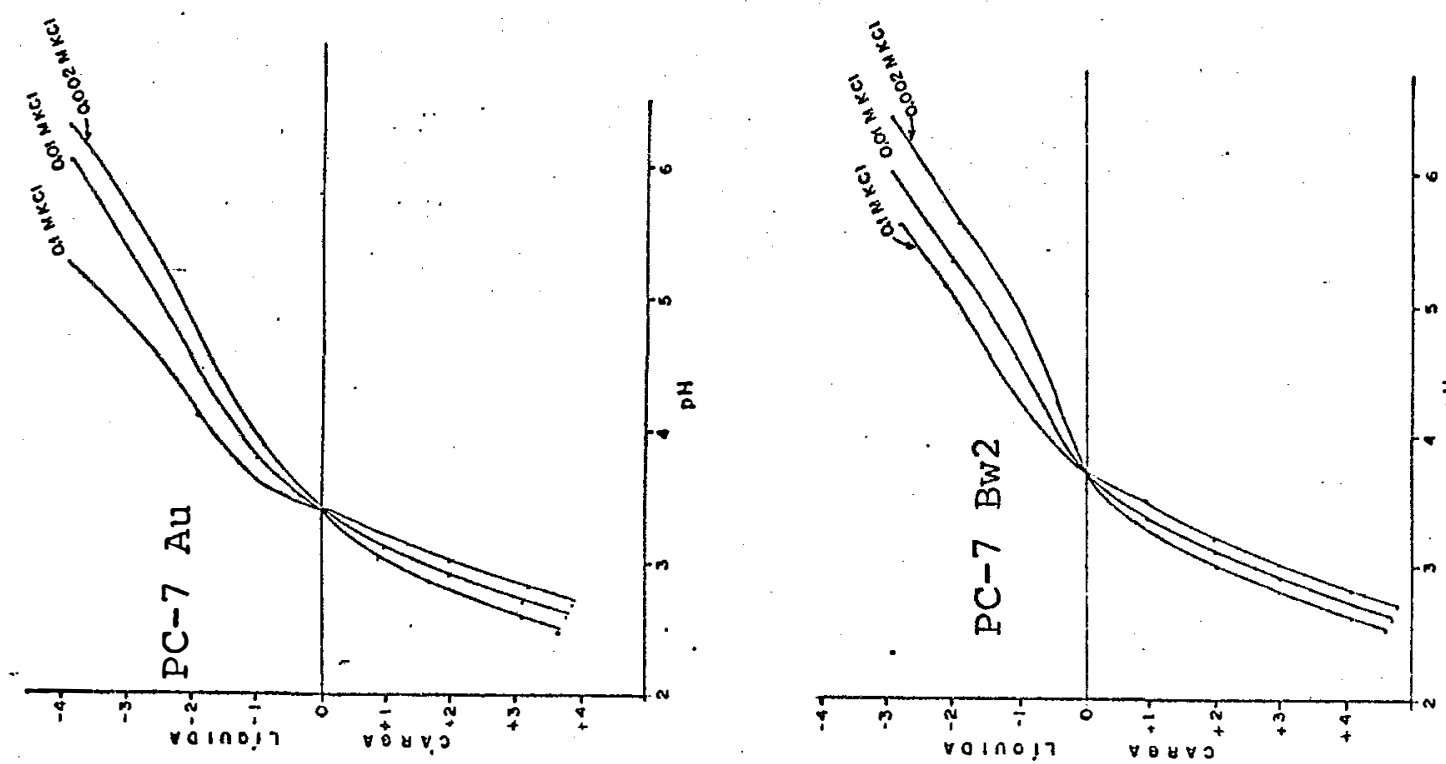

101.
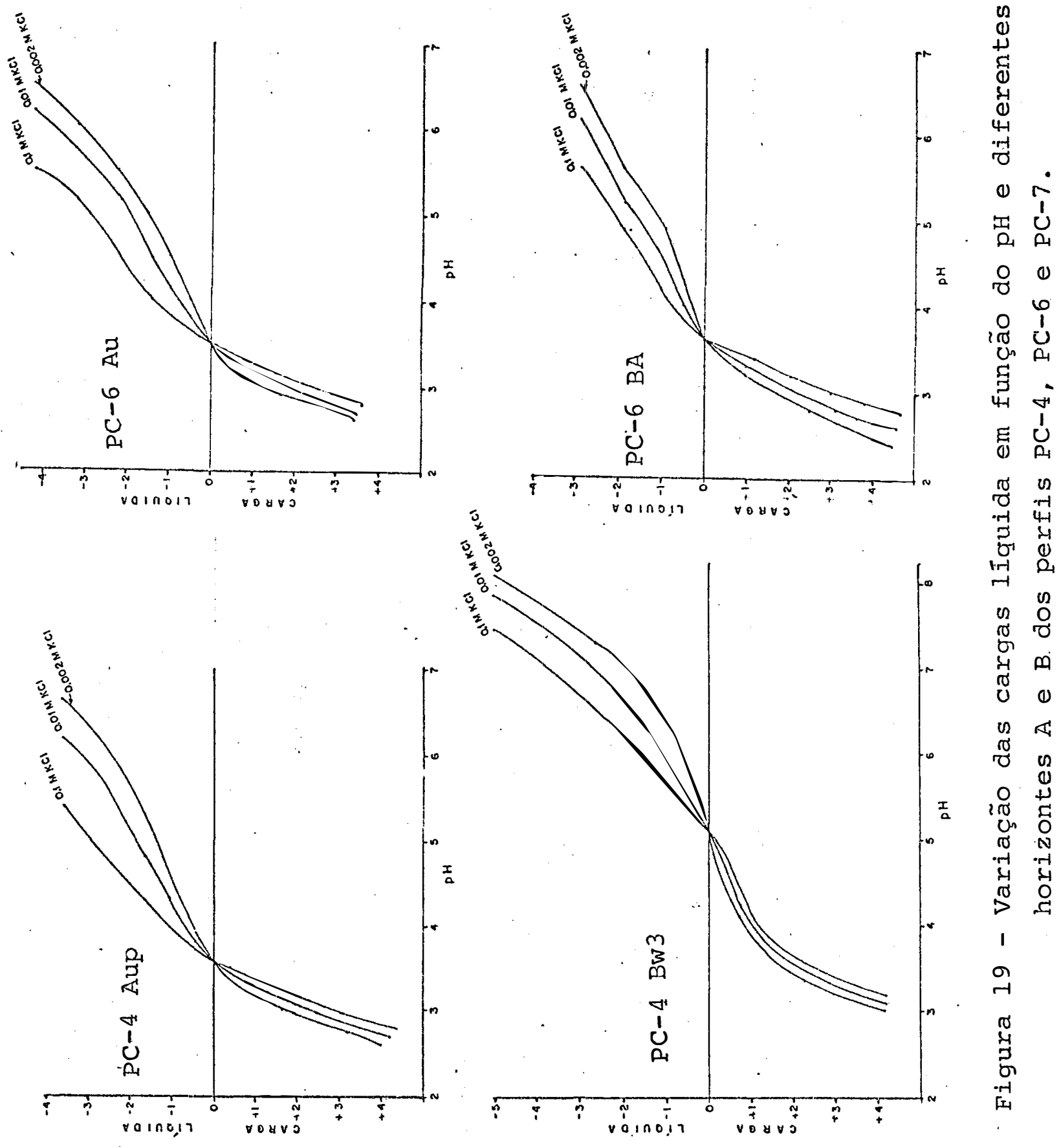

ช

2

$\frac{x}{a}$

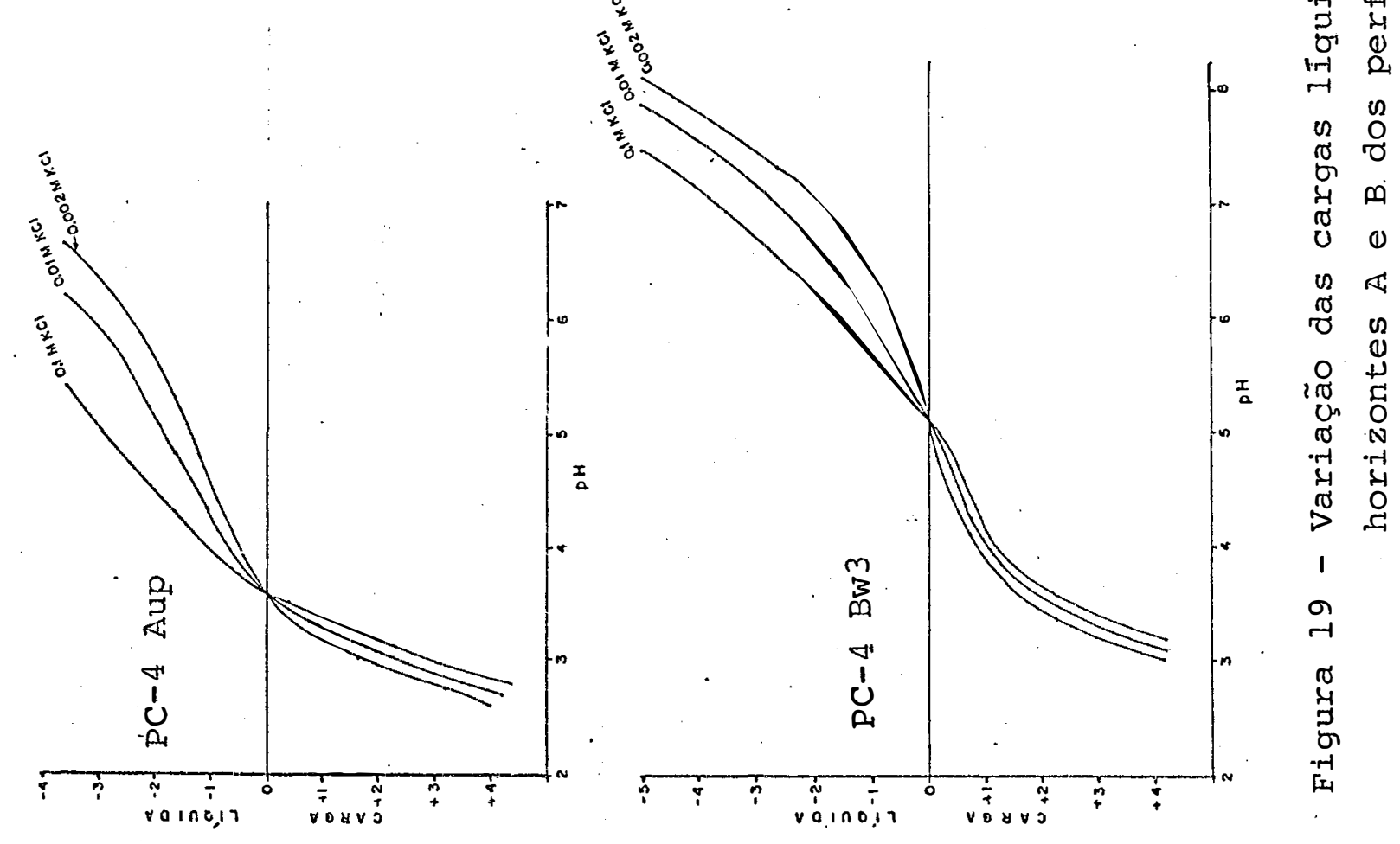


GALLEZ et alii (1976) consideram que a presenÇa de cargas negativas permanentes nos solos onde não sejam detectados minerais de argila $2: 1$, deve-se a substituição estrutural na caulinita e óxidos de ferro. Tem sido evidenciado que a substituição isomórfica de $\mathrm{Al}^{3+}$ por $\mathrm{Si}^{4+}$ na camada tetraédrica da caulinita e a substituição estrutural de íons de $\mathrm{Mg}^{2+}$ e $\mathrm{Li}^{+}$por $\mathrm{Fe}^{3+}$ na hematita e goethita dará lugar a uma superfície de carga negativa permanente excessiva (FOLLET, 1965 e GRIM, 1968).

A presumivel existência de cargas negativas per manentes nestes solos pode ser considerada pelo baixo conteúdo de matéria orgânica no horizonte $B$ em relação ao horizonte A (Tabela 8), não observando-se elevação significante do PCZ no horizonte $\mathrm{B}$ dos perfis PC-1, PC-2, PC-6 e PC-7. De acordo com PARFITT (1980) O PCZ. decresce com o aumento no conteúdo de matéria orgânica ou de minerais tendo substituição isomórfica elevada.

Quanto aos perfis PC-3 e PC-4 com valores de PCZ aumentando do horizonte A para o horizonte B observa-se a influência da matéria orgânica decrescendo O PCZ no horizonte A e a dos óxidos de ferro e alumínio (goethita, hematita e gi.b bsita) em elevar o valor do PCZ no horizonte B, pela pouca pre sença, ou inexistência, de cargas negativas permanentes nestes horizontes. No perfil PC-3 a maior diferença entre O PCZ do horizonte $A(3,6)$ e do horizonte $B(5,5)$ deve-se principalmen te a gibbsita (31 \% na fração argila) (Tabela 10).

GALLEZ et alii (1976) têm preconizado que o PCZ dos solos reflete o seu grau de intemperismo químico ou grau de dessilicatização, assim como, as caracterîsticas de cargas dos öxidos de Fe e Al no solo, na seguinte ordem: alfis - 
solos < ultissolos < oxissolos com valores médios de PCZ de $3,4,4,0$ e 5,0, respectivamente. Em relação aos solos estudados os mais intemperizados são os correspondentes aos perfis PC-3 e PC-4 que têm valores de PCZ de 5,5 e 5,1 no horizonte $B$, respectivamente, estando portanto dentro dos oxissolos.

Admitindo-se a hipótese que o $\mathrm{Al}^{3+}$ trocāvel (Ta bela 9) determinado com $\mathrm{KCl}$, seja todo adsorvido pelas cargas negativas variáveis e permanentes, pode-se notar que as cargas negativas nestes solos variam de 0 (zero) a 8,4 me/100 g de solo.

Os resultados obtidos nestes solos permitem afirmar que os mesmos seguem o sistema de cargas variáveis, mesmo contendo alguma carga negativa permanente. Isto está de acordo com as constatações realizadas, para solos tropicais, com argila de baixa atividade, de apresentarem sistema de cargas variáveis, pelos estudos de VAN RAIJ (1972) e MORAIS et alii (1974) no Brasil, KENG e UEHARA (1973) com solos do Hawai e GALLEZ et alii (1976) com solos da Nigéria.

Oṣ resultados químicos têm demonstrado que os solos são, regra geral, bem intemperizados, havendo na sequên cia distinção para os perfis PC-1, PC-2 e PC-5, menos evoluí do e os perfis PC-3, PC-4 e PC-7 mais intensamente intemperizados. Isto se explica pela posição que tais solos ocupam na paisagem ( $P C-3, P C-4$ e PC-7), localizados em superfícies mais planas e estáveis, sujeitas a um fluxo vertical mais intenso, resulta num maior grau de intemperismo. Por outro lado, os outros perfis que se localizam em áreas mais elevadas, ací 
dentadas e instáveis, estão mais sujeitas a erosão e um menor fluxo vertical, resultando em solos menos evoluídos. Quimicamente, todos os solos podem ser enquadrados como sendo oxis solos, mesmo os perfis PC-1, PC-2 e PC-5, que são mais rasos. O perfil PC-7 também, possuem cargas líquidas positivas, no horizonte Bwb, demonstrando, justamente, o avançado grau de intemperismo deste solo. .

\subsection{Mineralogia}

5.4.1. Oxidos de ferro, alumínio e manganês

Os óxidos de ferro, alumínio e manganês extraídos do solo em três formas são apresentados na Tabela 11 .

Os óxidos de ferro extraídos pelo método do ataque sulfürico $\left(\mathrm{H}_{2} \mathrm{SO}_{4} \mathrm{l}: 1+0,8 \div \mathrm{NaOH}\right)$, ou $\mathrm{Fe}-\mathrm{H}_{2} \mathrm{SO}_{4}$ são considerados óxidos de ferro totais por VETTORI (1966), pelo fato deste método extrair as mais diferentes formas de ferro encontradas no solo, inclusive o ferro retido nas camadas dos minerais de argila silicatada. Os teores de óxidos totais nes tes solos variam de 5 a 12\%, e de maneira geral apresentam um pequeno aumento com a profundidade, com exceção para o per fil PC-5, que apresentam valores mais altos nos horizontes su perficiais, devido a estes horizontes serem residuais e zona de concentração de ferro. 


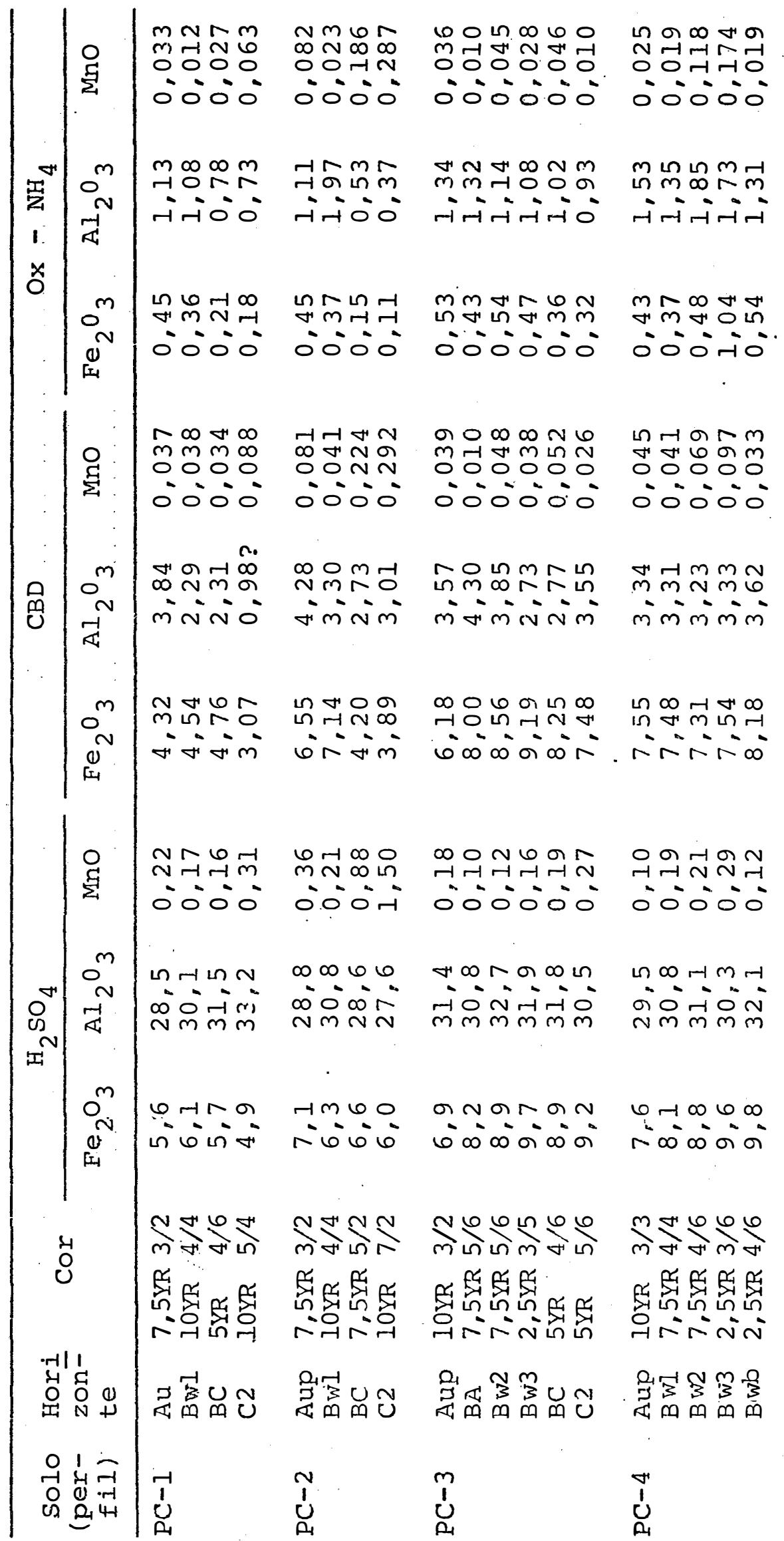




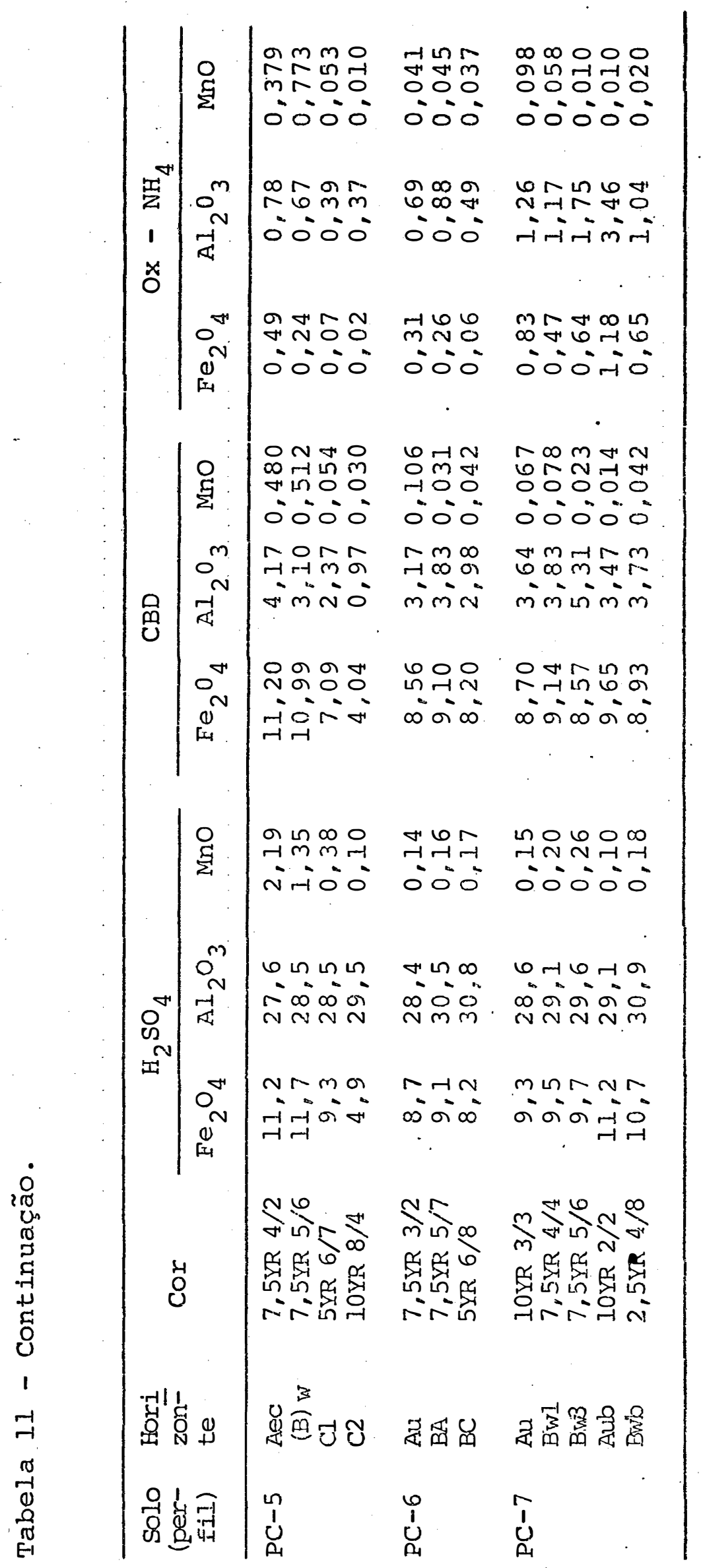


o conteúdo de óxidos de ferro extraỉdo pelo mé todo do citrato-bicarbonato-ditionito (CBD) ou. Fed, considerados como óxidos de ferro livres por JACKSON (1969), . são representados pela maior parte dos óxidos e hidróxidos crista linos e amorfos de ferro, assim como, os sais e complexos orgânịcos de ferro (MCKEAGUE e DAY, 1966 e MCKEAGUE et alii, 1971). De acordo com MOORE (1973) não se pode afirmar que o método do $C B D$ extrai todo o ferro que não esteja retido nas camadas dos minerais silicatados. Os teores de óxidos de fer ro livre (Fed) nos solos variam de 3\% a ll\%, com alguns valores iguais aos dos óxidos de ferro total. Segundo VETTORI (1975) o ferro livre deveria ser de aproximadamente $90 \%$ do ferro total. Contudo, nestes solos observa-se uma diferen ça mais significativa entre estes valores, principalmente nos perfis PC-1 e.PC-2. Essa diferença pode ser devida à presença nestes solos de minerais silicatados com $\mathrm{Fe}$, ou de compostos de ferro bastantes resistentes à extração do mesmo' com CBD. De acordo com JACKSON (1969) o método do CBD extrai os óxidos de ferro amorfos e os cristalinos, como hematita, goethita e lepidocrocita e parcialmente a magnetita e ilmenita. A presença de goethita altamente Al- substituida pode ser uma das causas, assim.como, a magnetita que está presente no material de partida destes solos.

NORRISH e TAYLOR (1961), BIGHAN et alii. (1978a), POMBO et alii (1982) e SCHWERTMANN (1983) comprovaram que a goethita e hematita, contendo quantidades elevadas de Al estru tural, além de decrescer o tamanho de partículas, também aumen ta sua estabilidade e área superficial específica, indo influir na dissolução e estabilidade de agregados.

Os teores de $\mathrm{Fe}-\mathrm{H}_{2} \mathrm{SO}_{4}$ e Fed mais elevados ob servados nos dois primeiros horizontes, assim como, a presença de concreções lateríticas no perfil PC-5, parece estar re- 
lacionado à migração lateral do ferro da crista, e, sua emergência na transição crista encosta, onde, encontrando condi ções de oxidação, ocorrem precipitações isoladas inicialmente e formação de concreções lateríticas por repetição do processo (ALEXANDER e CADY, 1962). Segundo Aubert citado por MONIZ e JACKSON (1967) e SCHWERTMANN (1971), o ferro pode ser removido durante a evolução genética. Isto parece que está ocorrendo não só na área do perfil PC-5, mas também, nas quebras do rèlevo da superfície das áreas I e II, onde cores acromáticas são encontradas.

O método do oxalato de amônio extrai os óxidos de ferro considerados amorfos por MCKEAGUE e DAY (1966), ou Fe-oxalato que é presumível remover os óxidos de ferro na forma amorfa ao raio-x, complexos orgânicos e somente pequena parte do ferro na forma cristalina. Os teores de óxidos de ferro amorfos (Fe-O) nos solos são muito baixos, com a tendência ge ral em decrescer com a profundidade, a eisceção dos perfis PC-4 e PC-7 que não apresentam esta sequência, devido aos teo res elevados de matéria orgânica (carbono) nos horizonte Bw3 e Aub, respectivamente.

Os teores de Feo mais elevados nos horizontes superficiais, decrescendo com a profundidade, e, nos hori zontes $\mathrm{Bw} 3$ e Aub, dos perfis $\mathrm{PC}-4$ e $\mathrm{PC}-7$, respectivamente, de monstra existir uma relação entre eles e o conteúdo de maté ria orgânica. Isto porque, segundo SCHWERTMANN et alii (1968) os compostos orgânicos podem reter os óxidos de ferro (e alu mínio) amorfos, previnindo ou retardando a sua cristalização, o que explica esta distribuição.

A relação Feo/Fed (Fe--oxalato/Fe-ditionito) (Tabela 12) ou "Fe ativo" (BLUME e SCHERTMANN, 1969) è uma indicação das quantidades relativas dos compostos de ferro 
NHMN

(1)

$\stackrel{\cap}{\text { m }}$

ì

ח-

जัलिभ

Fก

$m m m \sim N$

N $\mathrm{N} N \mathrm{~m}$

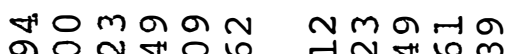

मन त मतन

- . - . त० नं के क

$0 \mathrm{~m}$

Hन

m $\mathrm{m} .6$

mi 0

HNH

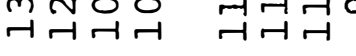

समिंके

o $6 \infty \sim m m$

$\because \ldots$

nN

नं

o $m$ ำ

तेंक

$\sigma$

'.

$m$ in $N$

$\rightarrow m \omega \infty$

$\infty$
$\infty$$\underset{N}{\infty} \operatorname{rn}$

$\begin{array}{lll}\infty & \infty \\ 4 & \infty & 0 \\ \pi & 0 & 0\end{array}$

N 1 L

$\infty \infty \times 1$

$\infty 60 \mathrm{~m}$

ㄴำ 0.

No

NNm $\operatorname{Non}$

in $N 6 N$

a

i i

OेंN

Oें०

$06 \% 06$

मन्मा

0000

a $m \infty$ F

$\begin{array}{llll}0 & 0 & 0 & 0 \\ 0 & 0 & 0 & 0\end{array}$

r 000000

00000

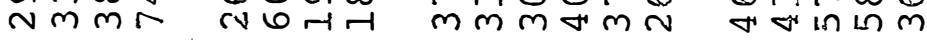

坓要

O

(1) 0

$\stackrel{4}{+} \underset{c}{4} \sigma$

8

先

1

N

$\underset{\sigma}{\sigma}$

疍

U.

$\bigcup_{1}^{m}$

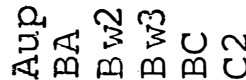

จ

공ำ

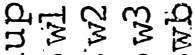

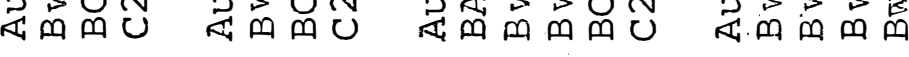




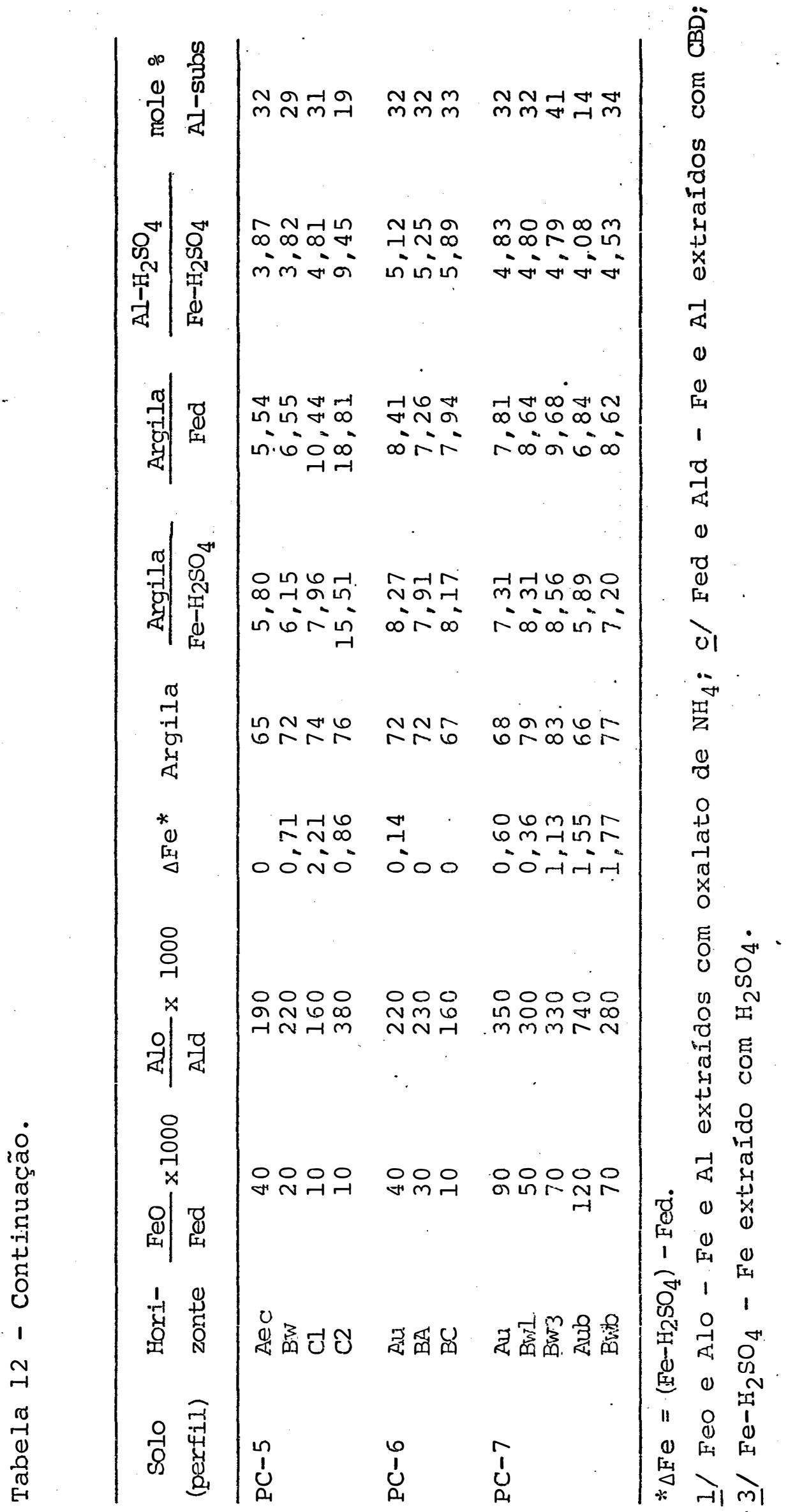


amorfos (Feo) e cristalinos, considerando-se que, a diferença entre os valores de ferro Fed e Feo representa a quantidade de fer ro na forma cristalina, os resultados indicam que o conteúdo de ferro nos horizontes subsuperficiais estão em sua maior parte na forma cristalina. Os valores de ferro ativo mais elevados nos horizontes superficiais e nos horizontes Bw3 e Aub dos perfis PC-4 e PC-7, respectivamente, deve-se a ação da matéria orgânica em inibir a cristalização dos óxidos de ferro amorfos.

Ao considerar que óxidos de ferro cristalinos aumentam às expensas dos óxidos de ferro amorfos, com o aumen to da idade do solo, vai refletir nos valores de ferro ativo (Fe ativo). ALEXANDER (1974) tem observado o Fe ativo decres cer com o aumento da idade do solo. Levando-se em consideração o ferro ativo, os solos correspondentes aos perfis PC-5 e PC-6, seriam os de maior idade entre os solos estudados.

A tendência dos valores de $\mathrm{Fe}$ ativo em decrescer com a profundidade, demonstra a inexistência de acúmulos de óxidos de ferro amorfos nos horizontes subsuperficiais. MC KEAGUE e DAY (1966) têm observado que o Fe ativo serve como indicador de produtos recentes de intemperização e horizontes de acumulação. Os teores elevados de $\mathrm{Fe}$ ativo nos horizontes Bw3 e A.ub nos perfis PC-4 e PC-7, não caracterizam horizontes de acumulação, devido os mesmos corresponderem a horizontes de solos enterrados.

A baixa relação Feo/Fed nos solos não excedendo a 140 indica que os óxidos de ferro estão em sua maioria na forma cristalina e, a predominância dos valores desta rela ção em torno. de 60 ou menor, indica a presença de goethita nes tes solos (SCHWERTMANN, 1964; GAMBLE e DANIEIS, 1972; POTTER, 1977). 
Os valores de $\Delta \mathrm{Fe}$ (Tabela 12) mais elevados, encontrados na maioria dos perfis, parece relacionar-se a resistência a dissolução dos óxidos de ferro com CBD (três vezes), devido a elevadas quantidades de Al-substituição, do que a presença de Fe nos minerais silicatados.

As relações argila:Fe- $\mathrm{H}_{2} \mathrm{SO}_{4}$ e argila:Fed, apre sentam uma certa semelhança entre si, a exceção dos perfis PC-1, PC-2 e PC-5. A aparente constância destes valores com a profundidade, sugere que nestes solos não ocorre acumulações de ferro independente da concentração de arg̣ila. A variação observada nos perfis $\mathrm{PC}-1, \mathrm{PC}-2$ e PC-5, deve-se a um enriquecimento do fer ro pelo fluxo lateral nesses perfis.

A respeito dos métodos de extração do ferro so bre o Al e Mn nos solos, BLUME e SCHWERTMANN (1969) sugerem que o Mn extraído com CBD consiste de Nin não retido nas camadas dos minerais silicatados. Enquanto que para o Al extraí-do por CBD grande parte do mesmo vem dos óxidos de ferro, ape sar de serem fontes de $A l$, os argilo-minerais e óxidos cristalinos e amorfos de Al. NORRISH e TAYLOR (1961) observaram que grande parte do Al extraído dos solos na remoção dos óxidos de ferro, livre com CBD, foram originados da dissolução de goethitas. Também observaram que a dificuldade na remoção de goetini ta usando tratamento simples de ditionito parece estar associado com a presença de Al na estrutura da goethita.

Os teores de óxidos de aluminnio total $\left(\mathrm{Al}-\mathrm{H}_{2} \mathrm{SO}_{4}\right)$ variam nestes solos de 27 a $33 \%$, com valores relativamente mais baixos nos horizontes" superficiais,e, com valores razoavelmente constantes nos horizontes subsuperficiais e superiores aos teores de óxidos de ferro. Esta constância nos valores de $\mathrm{Al}-\mathrm{H}_{2} \mathrm{SO}_{4}$ parece evidenciar também uma certa homogeneidade ao material de partida dos solos. 
Os teores de alumínio do extrato de CBD (Ald) Tabela ll) apresentam-se variando nos solos de 0,98 a 5,31 \%, com valo res mais elevados nos horizontes superficiais, decrescendo com a profundidade, a exceção dos perfis PC-4, PC-6 e PC-7, que não apresentam esta tendência. Tal fato parece estar associa do à presença de matéria orgânica.

Os teores de Al extraídos com oxalato de amô nio ácido $\left(\mathrm{Ox}-\mathrm{NH}_{4}\right)$ compreende valores variando de 0,40 a 3,50 \%, demonstrando uma tendência em decrescer com a profundidade semelhante ao do ferro amorfo, com as mesmas observações em relação os teores de Ald, para os perfis PC-4, PC-6 e PC-7.Os teores de Alo $\left(\mathrm{Al}-\mathrm{Ox}-\mathrm{NH}_{4}\right)$ mais elevados nos horizontes superficiais e decrescendo em profundidade nestes perfis, demons tra a existência de uma associação entre estes e o contéūo de matéria orgânica. A mesma observação feita para os óxidos de ferro amorfos em relação a matēria orgânica por ScHWERTMANN et alii (1968) aplica-se aos teores de aluminio amorfos Alo para explicar esta distribuição.

Pelo fato de que os teores dos óxidos de alumî nio extraídos com CBD ( $\mathrm{Ald}$ ) serem mais elevados do que aque les dissolvidos pelo oxalato (Alo) (Tabela l.l) seria uma indi cação de sua origem numa matriz cristalina. Enquanto que, as pequenas quantidades de Feo (Tabela ll) sugere que a mistura de óxidos cristalinos de ferro não seja uma fonte significante de Alo (FEY e LEROUX, 1977).

Os teores de manganês total $\left(\mathrm{Mn}-\mathrm{H}_{2} \mathrm{SO}_{4}\right.$ ) (Tabela 11) nestes solos variam de 0,10 a $2,19 \%$, com a tendência geral em aumentar com a profundidade. O aumento da concentra ção em profundidade, relaciona-se ao movimento do elemento no sentido vertical no perfil, devido a solubilização do mesmo,a 
partir da alteração de minerais que tenha o Mn como um dos seus constituintes. Esta assertiva parece comprovar-se atravês dos teores de manganês extraỉdos por ditionito (Mnd) e oxalato (Mno) que são mais baixos em. relação ao $\mathrm{Mn}-\mathrm{H}_{2} \mathrm{SO}_{4}$.

Os valores elevados de Mn nos horizontes super ficiais do PC-5 deve-se a concentrạ̧ão na cascalheira em pro"cesso semelhante ao que ocorre com o ferro.

o conteúdo de Mnd e Mno determinados nestes so los apresentam distribuição semelhante aos do $\mathrm{Mn}-\mathrm{H}_{2} \mathrm{SO}_{4}$, com os valores de Mnd normalmente superiores aos de Mno.

Os teores de óxidos de ferro total extraído pelo ataque sulfúrico $\left(\mathrm{Fe}-\mathrm{H}_{2} \mathrm{SO}_{4}\right)$, tềm sido utilizados por BENNEMA e CAMARGO (1964) como caracterîstica diferencial na distinção de classes de Latossolos. Admitindo este critério, todos os perfis estudados seriam classificados como Latossolo Vermelho Amarelo, por apresentarem valores de "Fe total", dentro do intervalo previsto para esta classe de solo ( $\leq 9 \%$ de $\mathrm{Fe}_{2} \mathrm{O}_{3}$ no horizonte $\mathrm{B}$ ).

o conteúdo de óxidos de ferro e alumínio livre (CBD) e amorfos $\left(\mathrm{Ox}-\mathrm{NH}_{4}\right)$ determinados na fração argila (Tabela 13), apresentam.distribuição semelhante aos encontrados na fração terra fina (<2 mm) (Tabela 11).

A substituição de Al estrutural nos óxidos de ferro na fração argila $(<2 \mu)$ destes solos (Tabela 13), basea dos nos valores de $\mathrm{Fe}$ e Al obtidos pelo CBD e oxalato, variam de 23 a 57 mole \%. Segundo FITZPATRICK e SCHWERTMANN (1982), o grau de Al-substituição e a cristalinidade dos óxidos de ferro, são utilizados como indicador de processos de formação 
ํํำ

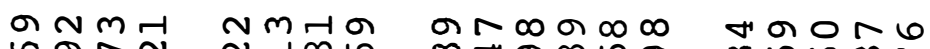

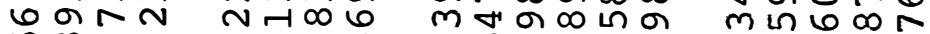
nm

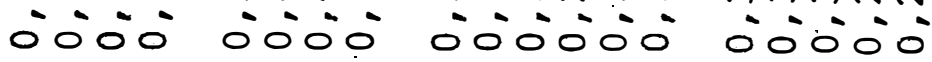

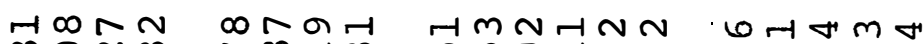
moNm स 6 ก '000 0000 000000

Iㅇㅁ $\overbrace{\pi}^{m}$ 0 ด 06 min แก $10 \infty$ .... - बm זू

개 $\mathrm{m} N$ $0^{m}$ N in

a 6 HNN N N

नेंतेंते 谣

ก

Q̊mon

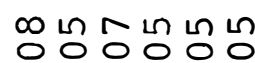

겅ㅇㅇ융ำ

0ं00

isio

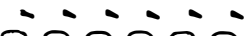

O०000'

i⿱乛龰

శ్ర

•

1

$m$

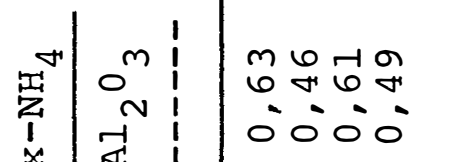

$6 \rightarrow m^{\prime}$

i.

a. $\operatorname{arn} \pi \mathrm{n}$

ब $\infty$ o $\infty$ in

io $-i$

$6 \cos ^{2} \rightarrow$

0000

000000

तN $\infty$

तrrifí

$\infty 6 \sim 0$ 60 0

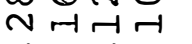

mân

$\infty \sim \infty \neg-6$

\#m $m$ 出

ヘルก

0000

Oं००

000000

O००००

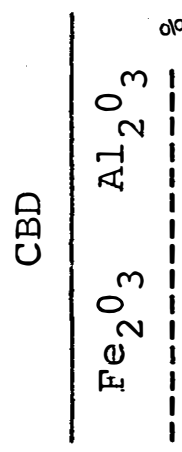

$\infty 6 \circ \mathrm{m}$

$6 m 6 r$

In $-16 \mathrm{~m}$

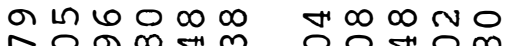

mंกंก

$N \cdot m_{-1}$

$00 \pi 0 \infty$

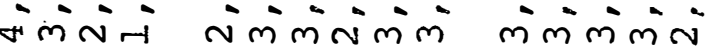

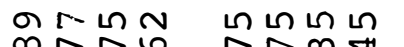

Hm 600 r

ヘேダダ

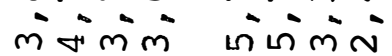
OD $60 \mathrm{NO}$ -..................... Untion

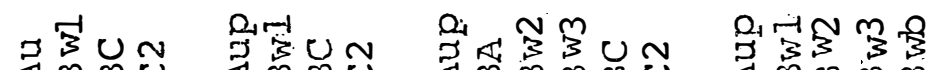

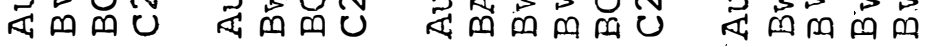

ín

ú

皇

ل' 


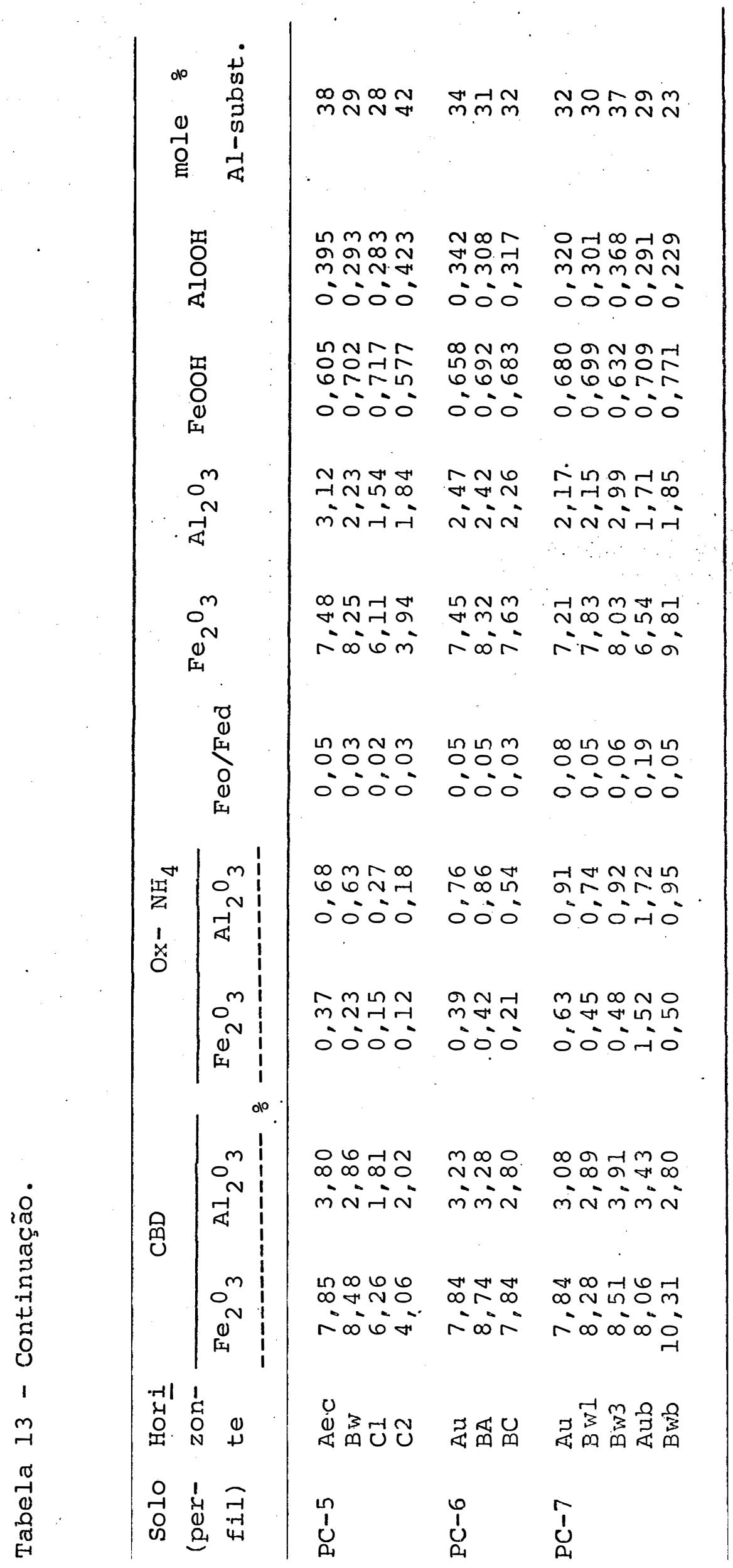


do solo, de maneira que os teores mais elevados, seriam obser vados nos solos mais intemperizados, devido a maior disponibi lidade de $\mathrm{Al}^{3+}$.

Os elevados teores de Al-substituição constata dos principalmente nos perfis PC-1 e PC-2, deve-se a uma maior disponibilidade de $\dot{A}^{3+}$, pelo decréscimo do $\mathrm{pH}$ e đaimi nuição na cristalinidade dos óxidos de ferro presentes nestes solos. O óxido de ferro predominante nos solos parece ser a goethita mal cristalizada. SCHWERTMANN (1983) tem observado que a presença de Al no meio pode influenciar a formação de óxi dos de ferro, de modo que Al em pequena concentração favorece a formação de hematita, enquanto que grande quantidade de Al favorece a formação de goetita. Além disso a. Al-substituição na hematita é no mäximo de $1 / 6$ do conteúdo de ferro.

A elevada substituição de Al nos óxidos de fer ro, como visto na Tabela 13, e um alargamento nos picos de di fratogramas de raios- $X$ correspondentes a goethita (FITZPATRICK e SCHWERTMANN, 1982 e SCHWERTMANN, 1983) de amostras da fração argila tratadas com $\mathrm{NaOH} 5 \mathrm{~N}$, parece concordàr com a pre-missa de que os óxidos de ferro presentes nestes solos seja a goethita mal cristalizada (Figura 20). Este alargamento dos picos da goethita tem sido interpretado por SCHWERTMANN (1983) como decréscimo na cristalinidade da goethita Al-substituída.

Os valores de Al-substituição observados nos solos, permitem admitir que a goethita nos perfis PC-3, PC-4, PC-5, PC-6 e PC-7, se encontra em grau de cristalinidade maior que nos perfis $\mathrm{PC}-1$ e $\mathrm{PC}-2$.

A diferença observada na percentagern de Al-subs tituição entre os óxidos de ferro determinados na fração ter- 


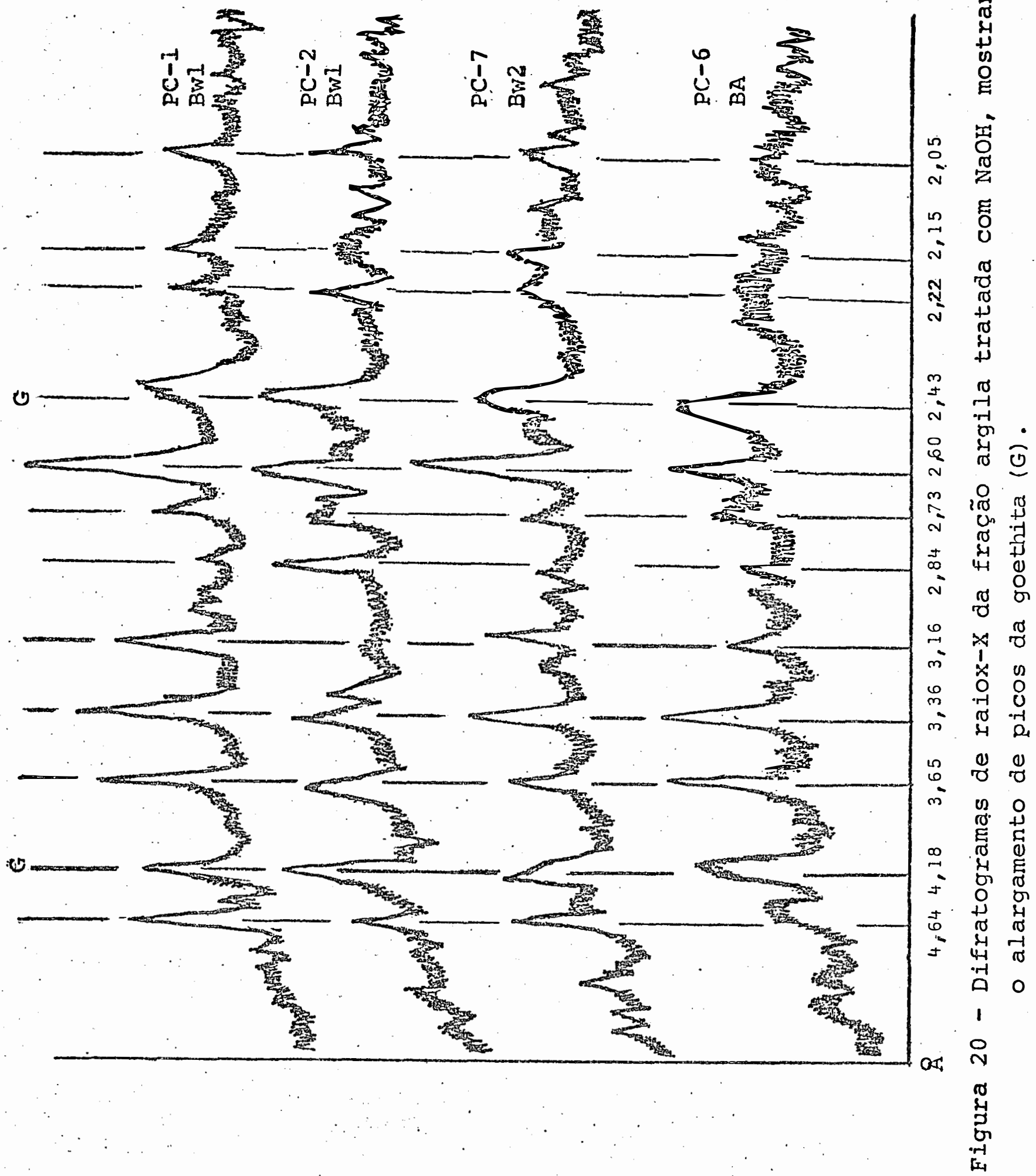


ra fina ( $<2 \mathrm{~mm}$ ) (Tabela ll) e na fração argila ( $<2 \mu$ ) (Tabela 13) relaciona-se à presença nas frações areia e silte de tipo de óxidos de ferro com menor grau de Al-substituição que na fração argila.

Com referência aos valores de Al-substituição mais baixos observados nos horizontes B dos perfis PC-3, PC-4 e PC-7, que apresentam coloração no matiz 2,5YR (Tabela 11), deve-se a contribuição da hematita presente nesses horizontes, como evidenciados pelos difratogramas de raios-X (Figura 21).

As cores bruno, bruno forte e amarelo averme lhado nestes solos são em parte resultantes da presença de goethita, enquanto que, as cores vermelhas são devido à presença de cristais muito pequenos de hematita presentes nos so los.

A coloração mais avermelhada $(2,5 \mathrm{YR})$ em hori zontes subsuperficiais dos perfis PC- 3 , PC-4 e PC-7, relaciona-se à preservação da hematita nesses horizontes, enquanto que, a coloração amarelada dos horizontes superiores deve-se à transformação da hematita em goethita (SCHWERTMANN, 1971 e SCHWERTMANN e TAYLOR, 1977). A Figura 21 ilustra este fato, pela presença de goethita em horizontes superficiais e a hema tita ou hematita e goethita nos horizontes subsuperficiais.

\subsubsection{Mineralogia da fração areia}

A estimativa do conteúdo dos minerais contidos na fração areia foi baseada na comparação entre a área dos pị cos de maior intensidade dos respectivos minerais detectados nos difratogramas de raios-X e das amostras padrōes da mistura de quartzo, gibbsita, caulinita e feldspato-K. 


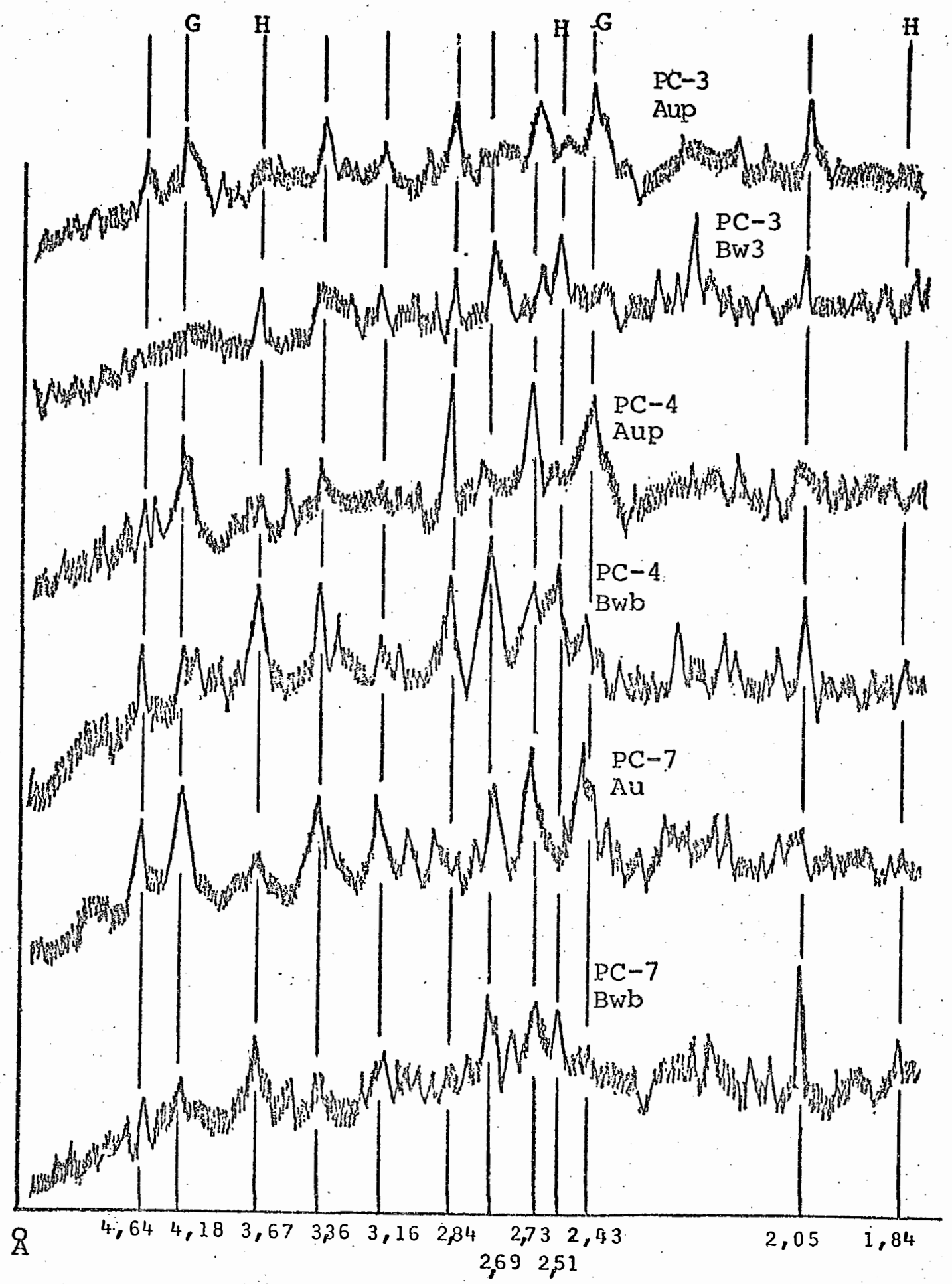

Figura 21 - Difratogramas de raios-X da fração argila tratada com $\mathrm{NaOH}$, mostrando a predominância de goethití (G) nos horizontes A com coloração brunada e de hematita nos horizontes $B$ de coloração vermelha. 
A identificação dos minerais constituintes des ta fração foi realizada atravēs dos picos de difração de raios$x$, assim que, a gibbsita foi identificada pelos picos 4,85. e $4,37 \AA ;$ o quartzo pelos picos 4,27 e 3,36 $;$ a caulinita pelos picos em 7,13 a $7,19 \AA$ e 3,53 a $3,57 \AA ;$ f feldspato pelos pi$\cos 3,24$ e $3,18 \AA ;$ a mica pelo pico em $10 \AA$ e 0 anatásio pelos picos 3,53 e $1,89 \AA$.

Os constituintes mineralógicos da fração areia identificados por difratometria de raios-X, são apresentados na Tabela 14. A fração areia é conscituída por gibbsita e quartzo como minerais dominantes, seguindo-se em menores quan tidades a caulinita, mica e feldspatos (Figuras 22 e 23). A caulinita está presente na fração areia de todos os solos, en quanto que a mica e o feldspato não foram observados no perfil PC-4 e somente a mica não foi evidenciada no perfil PC-6 e PC-7. A ocorrência, tanto da caulinita como da gibbsita,na fração areia, deve-se a formação de nódulos do tamanho desta fração. Isto é possível ocorrer principalmente se as condi ções de pedogênese forem favoráveis.

O acúmulo de feḷdspato nos horizontes superficiais do perfil PC-l, reflete um possivel aporte de material de composição semelhante, do afloramento rochoso na crista, próximo deste perfil. Isto parece comprovar-se pela baixa concentração de feldspato nos horizontes subsuperficiais.

A presença de gibbsita na fração areia pode cor responder à gibbsita primária, formada pela alteração direta de feldspatos. ANTONELLO (1982) estudando solos do maciço alcalino de Itatiaia, também observou a presença de gibbsita na fração areia, atribuindo a origem da mesma a alteração de felds pato, nefelina e biotita. 
Tabela 14 - Estimativa semi-quantitativa dos constituintes mi neralógicos da fração areia de horizontes selecio nados por difratometria de raios-X.

\begin{tabular}{|c|c|c|c|c|c|c|}
\hline $\begin{array}{c}\text { Solo } \\
\text { (perfil) }\end{array}$ & $\begin{array}{l}\text { Hori- } \\
\text { zonte }\end{array}$ & $\begin{array}{l}\text { Gibbsi } \\
\text { ta }\end{array}$ & Quartzo & $\begin{array}{l}\text { Cauli- } \\
\text { nita }\end{array}$ & Mica & $\begin{array}{l}\text { Felds- } \\
\text { pato }\end{array}$ \\
\hline \multirow[t]{4}{*}{$P C-1$} & $\mathrm{Au}$ & G3* & Q1 & $\mathrm{Cl}$ & $\mathrm{MiC}$ & F 3 \\
\hline & BWl & G4 & Q1 & $\mathrm{Cl}$ & MiO & F2 \\
\hline & $B C$ & G4 & Q1 & $\mathrm{C} 2$ & Mil & Fl \\
\hline & $\mathrm{C} 2$ & G3 & Q2 & $\mathrm{C} 2$ & Mi2 & $\mathrm{F} 1$ \\
\hline \multirow[t]{4}{*}{$P C-2$} & Aup & G4 & Q2 & $\mathrm{Cl}$ & $\mathrm{MiO}$ & $\mathrm{Fl}$ \\
\hline & BWl & G4 & Q2 & $\mathrm{Cl}$ & MiO & $\mathrm{Fl}$ \\
\hline & $\mathrm{BC}$ & G4 & Q2 & $\mathrm{Cl}$ & Mil & $\mathrm{Fl}$ \\
\hline & $\mathrm{C} 2$ & G3 & Ql & C3 & Mi2 & Fl \\
\hline \multirow[t]{6}{*}{$\mathrm{PC}-3$} & Aup. & G4 & Q2 & $\mathrm{Cl}$ & Mil & Fo \\
\hline & $B A$ & G3 & Q3 & $\mathrm{Cl}$ & Mil & $F 0$ \\
\hline & Bw2 & G3 & Q3 & $\mathrm{Cl}$ & Mil & Fo \\
\hline & $\mathrm{Bw} 3$ & G3 & $\mathrm{Q} 2$ & C2 & MiO & $\mathrm{Fl}$ \\
\hline & $B C$ & G3 & $\mathrm{Q} 2$ & $\mathrm{C} 2$ & MiO & Fi \\
\hline & $\mathrm{C} 2$ & G3 & $\mathrm{Q} 2$ & $\mathrm{C} 2$ & MiO & $\mathrm{F} 1$ \\
\hline \multirow[t]{5}{*}{ PC-4 } & Aup & G3 & Q3 & $\mathrm{CO}$ & Mio & Fo \\
\hline & $\mathrm{Bw} 1$ & G3 & Q3 & $\mathrm{Cl}$ & MiO & F0 \\
\hline & Bw2 & G4 & $\mathrm{Q} 2$ & $\mathrm{Cl}$ & $\mathrm{MiO}$ & F0 \\
\hline & $\mathrm{Bw} 3$ & G3 & Q3 & $\mathrm{C} \theta$ & MiO & F0 \\
\hline & Bwb. & G4 & Q3 & $\mathrm{Cl}$ & MiO & F0 \\
\hline \multirow[t]{4}{*}{$P C-5$} & Aec & G3 & Q.3 & $\mathrm{Cl}$ & $\mathrm{MiO}$ & E 0 \\
\hline & $\mathrm{BW}$ & G4 & Qo & $\mathrm{Cl}$ & $\mathrm{MiO}$ & $\mathrm{Fl}$ \\
\hline & $\mathrm{Cl}$ & G4 & Ql & $\mathrm{Cl}$ & $\mathrm{MiO}$ & $\mathrm{Fl}$ \\
\hline & $\mathrm{C} 2$ & $\mathrm{G} 4$ & Q1 & $\mathrm{C} 2$ & Mil & $\mathrm{Fl}$ \\
\hline \multirow[t]{3}{*}{$P C-6$} & $\mathrm{Au}$ & G4 & Q1 & C. & $\mathrm{MiO}$ & $\mathrm{F} 1$ \\
\hline & $\mathrm{BA}$ & G4 & Q1 & C0 & $\mathrm{MiO}$ & F.0 \\
\hline & $\mathrm{BC}$ & G4 & Q1 & $\mathrm{Cl}$ & $\mathrm{MiO}$ & F0 \\
\hline \multirow[t]{5}{*}{$\mathrm{PC}-7$} & $\mathrm{Au}$ & G4 & $\mathrm{Q} 2$ & C & MiO & $\mathrm{Fl}$ \\
\hline & $\mathrm{BW}^{\prime} 1$ & G4 & $\mathrm{Q} 2$ & $\mathrm{C} 0$ & MiO & Fo \\
\hline & BW 3 & G4 & 2 & $\mathrm{CO}$ & MiO & Fl \\
\hline & $A u b$ & G4 & $Q 2$ & $\mathrm{CO}$ & MiO & FO \\
\hline & Bwb & GA & Q2 & C0 & MiO & $\mathrm{FO}$ \\
\hline
\end{tabular}

* $4=>60 \%$

$3=30$ a $60 \%$

$2=10$ a $30 \%$

$1=<10 \%$

0 = não determinado. 


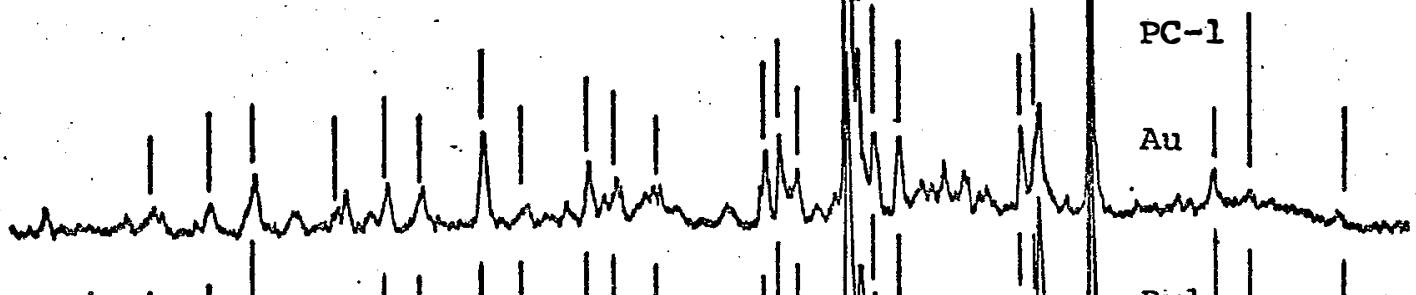

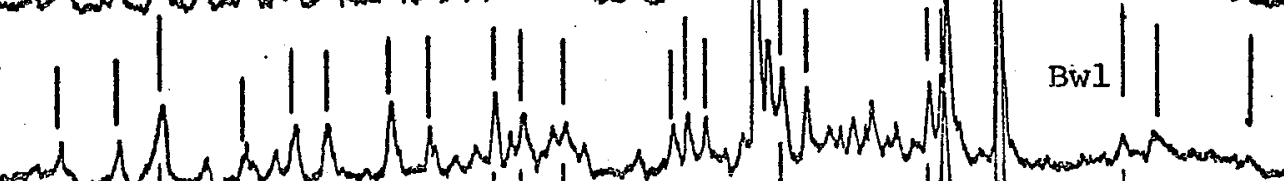
(1)

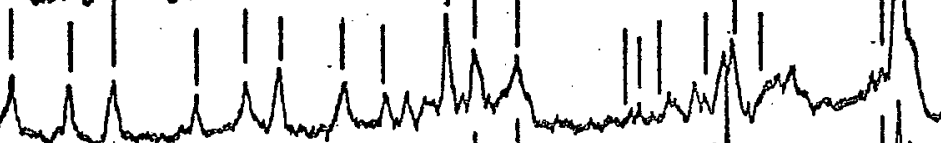

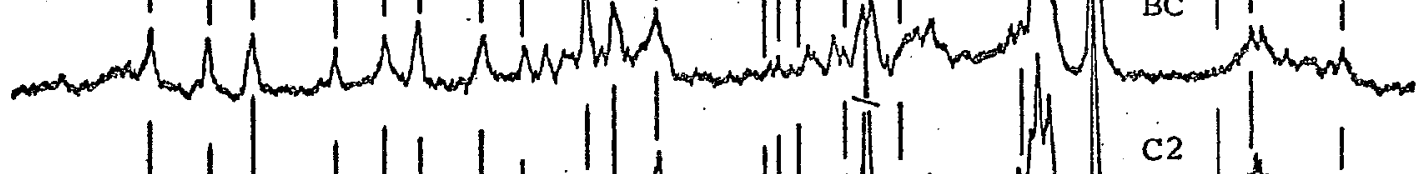

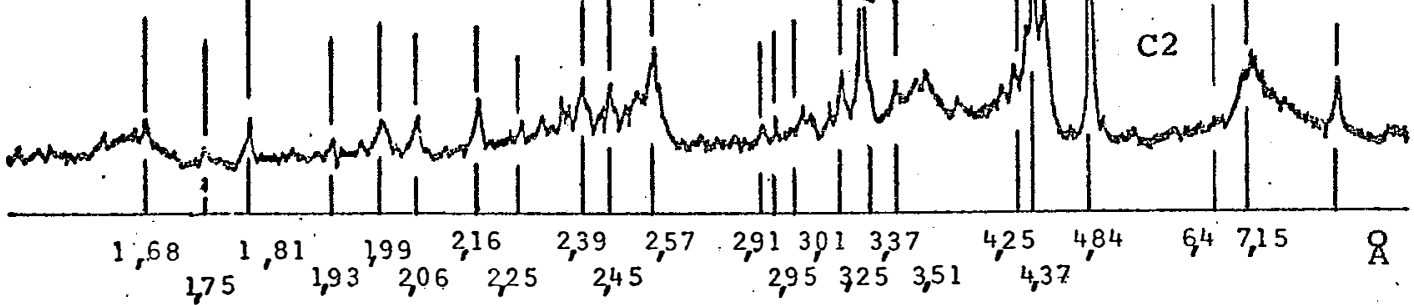
.

$|1| 1|1| 1|1| 1 \mid$ ind (N) and

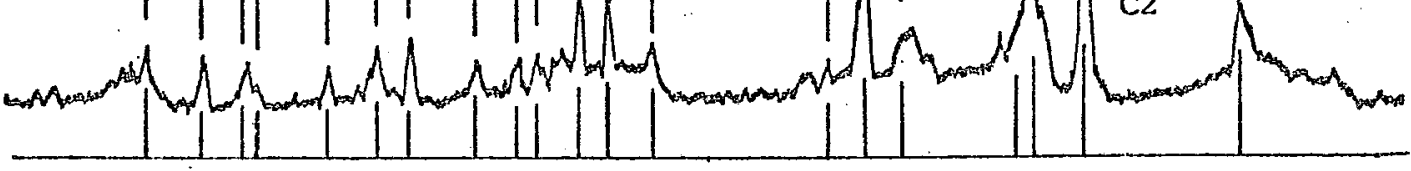

$\begin{array}{lllllll}3,58 & 3,80 & 1,93 & 2,06 & 27.5 & 23.9 & 2,57\end{array}$ $\begin{array}{llllll}1,75 & 1,81 & 699 & 2,16 & 2,27 & 2,45\end{array}$

$316 \quad 351 \quad 425 \quad 4884 \quad 7,55 \quad \&$ $\$ 3.7$

Figura 22 - Difratogramas de raios-X da fração areia (200$-50 \mu)$, sem óxiäos de ferro dos perfis PC-1 e PC-3 da área I. 


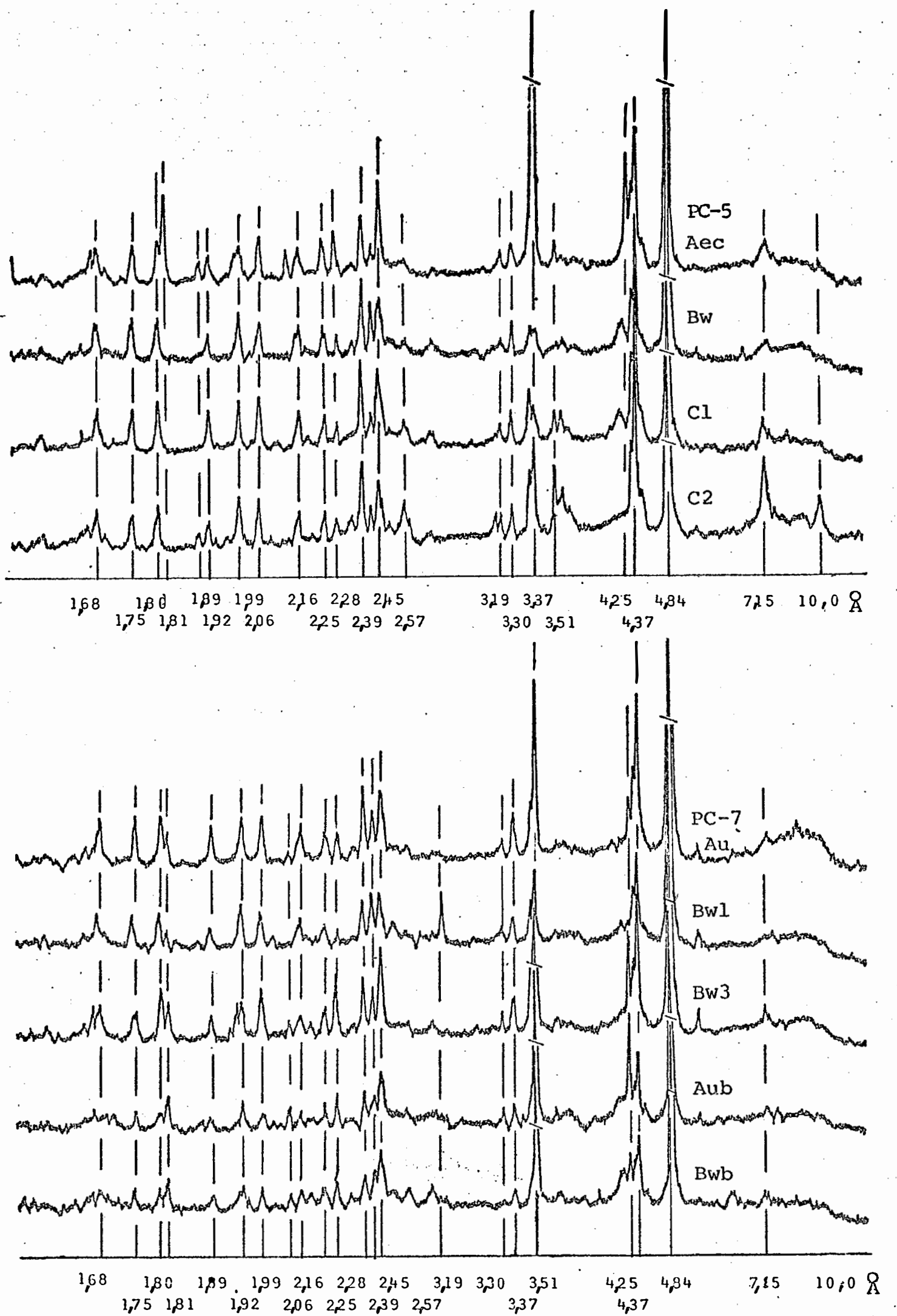

Figura 23 - Difratogramas de raios-X da fração areia (2000-50 $\mu$ ) sem óxidos de ferro dos perfis PC-5 e PC-7 da área II. 
o quartzo presente nestes solos é provavelmente de origem secundāria, orig̣inado pela dessilicatização rápi da do feldspato, com a silica acumulando-se nos vazios e subsequente cristalização. Isto parece comprovar-se pelo fato de as rochas alcalinas que deram origem a estes solos serem desprovidas de quartzo. Outra fonte, menos provável, que pode ser atribuida à presença de quartzo. nestes solos, seria a oriunda do arenito de Bauru, que ocorre na borda interna do maciço alcalino (ELLERT, 1969).

\subsubsection{Mineralogia da fração silte}

Os componentes mineralógicos da fração silte observados e estimados por difratometria de raiox-X (Tabela 15) são semelhantes aos encontrados na fração areia, onde foram evidenciados a presença de gibbsita, quartzo, caulinita, mica, feldspatos e anatasio, como revelam os difratogramas de raios-X (Figuras 24, e 25).

A estimativa do conteúdo percentual dos consti tuintes mineralógicos observados na fração silte, tambēm, foi realizada com base na comparação da área dos picos de maior intensidade dos respectivos minerais observados nos difrato gramas de raios-X das amostras padrões da misturas de quartzo, gibbsita, caulinita e feldspato-k.

A gibbsita, o quartzo, a caulinita e anatasio são encontrados em todos os perfis destes solos, enquanto que a mica e o feldspato foram constatados somente em alguns solos. A gibbsita na fração silte apresenta-se de uma maneira geral como mineral dominante, com exceção de alguns horizon tes dos perfis PC-3, PC-4 e PC-5, onde encontra-se o quartzo ou a caulinita como mineral dominante. 
Tabela 15 - Estimativa semi-quantitativa dos constituintes mi neralógicos da fração silte de horizontes selecio nados por difratometria de raios $\mathrm{X}$.

\begin{tabular}{|c|c|c|c|c|c|c|c|}
\hline $\begin{array}{c}\text { Solo } \\
\text { (perfil) }\end{array}$ & $\begin{array}{l}\text { Hori- } \\
\text { zonte }\end{array}$ & $\begin{array}{l}\text { Gibbsi } \\
\text { ta }\end{array}$ & $\begin{array}{l}\text { Quart } \\
\text { zo }\end{array}$ & $\begin{array}{l}\text { Cauli } \\
\text { nita }\end{array}$ & Miça & $\begin{array}{l}\text { Felds } \\
\text { pato- }\end{array}$ & $\begin{array}{l}\text { Anata } \\
\text { sio }\end{array}$ \\
\hline \multirow[t]{4}{*}{$\mathrm{PC}-1$} & $\mathrm{Au}$ & $\mathrm{G} 4$ * & Q2 & $\mathrm{Cl}$ & Mil & Fl & Anl \\
\hline & $B W I$ & G4 & QI & C2 & Mil & $F 1$ & Anl \\
\hline & $B C$ & G4 & Ql & C2 & Mi2 & F0 & Anl \\
\hline & $\mathrm{C} 2$ & G4 & Q1 & $\mathrm{C} 2$ & Mi2. & F 0 & An 0 \\
\hline \multirow{4}{*}{$\mathrm{PC}-2$} & $\mathrm{Au}$ & G3 & Q2 & $\mathrm{C} 2$ & Mil & $\mathrm{Fl}$ & Anl \\
\hline & BWI & G3 & $\mathrm{Q} 2$ & $\mathrm{C} 2$ & Mil & Fl & Anl \\
\hline & BC & G2 & Ql & C3 & Mi2 & F1 & An 0 \\
\hline & $\mathrm{C} 2$ & $\mathrm{Gl}$ & Q1 & C3 & Mi2 & $\mathrm{Fl}$ & An 0 \\
\hline \multirow{6}{*}{$P C-3$} & Aup & G4 & $\mathrm{Q} 2$ & $\mathrm{Cl}$ & Mil & $\mathrm{F} 0$ & Anl \\
\hline & $\mathrm{BA}$ & $\mathrm{G} 2$ & Q3 & $\mathrm{Cl}$ & Mil & Fo & Anl \\
\hline & Bw2 & G2 & Q3 & C2 & Mil & Fo & Anl \\
\hline & Bw3 & G3 & Q3 & $\mathrm{C} 2$ & MiO & F 0 & Anl \\
\hline & $B C$ & G3 & Q3 & $\mathrm{C} 2$ & $\mathrm{MiO}$ & F 0 & AnI \\
\hline & $\mathrm{C} 2$ & G3 & Q2 & C2 & Mil & F 0 & Ano \\
\hline \multirow[t]{5}{*}{$P C-4$} & Aup & G3 & Q3 & $\mathrm{Cl}$ & $\mathrm{Mi} 0$ & F0 & Anl \\
\hline & Bwil & G3 & Q3 & $\mathrm{Cl}$ & $\operatorname{Mi} 0$ & $\mathrm{~F} 0$ & Anl \\
\hline & Bw2 & G3 & Q3 & $\mathrm{C} 2$ & $\mathrm{MiO}$ & F0 & Anl \\
\hline & BW 3 & G3 & Q3 & $\mathrm{C} 2$ & Mi 0 & F 0 & Anl \\
\hline & Bwb & G3 & Q3 & $\mathrm{C} 2$ & $\mathrm{Mi} 0$ & F 0 & Anl \\
\hline \multirow[t]{4}{*}{$P C-5$} & Aec & G3 & Q3 & C2 & Mil & $\mathrm{F} 0$ & Anl \\
\hline & $\mathrm{Bw}$ & G2 & Q3 & $\mathrm{C} 2$ & Mil & F0 & Anl \\
\hline & $\mathrm{Cl}$ & G2 & Q2 & C3 & $\mathrm{Mi} 2$ & Fo & An 0 \\
\hline & C2 & $\mathrm{Gl}$ & $\mathrm{Q} 2$ & $\mathrm{C} 3$ & $\mathrm{Mi} 2$ & Fo & An. 0 \\
\hline \multirow[t]{3}{*}{ PC- 6} & $\mathrm{Au}$ & G4 & Q2 & $\mathrm{C} 2$ & MiO & Fl & An 2 \\
\hline & BA & G4 & Q2 & C2 & Mi0 & Fl & An2 \\
\hline & $\mathrm{BC}$ & G4 & $Q 1$ & $\mathrm{C} 2$ & $\mathrm{MiO}$ & Fl & An2 \\
\hline \multirow[t]{5}{*}{$P C-7$} & $\mathrm{Au}$ & G4 & $\mathrm{Q} 2$ & C2 & Mi0 & $\mathrm{Fl}$ & An2 \\
\hline & Bwl & G3 & $\mathrm{Q} 2$ & $\mathrm{C} 2$ & MiO & $\mathrm{Fl}$ & An2 \\
\hline & $\mathrm{Bw}_{\mathrm{w}}$ & G3 & $\mathrm{Q} 2$ & C2 & $\mathrm{Mi}, 0$ & Fl & An2 \\
\hline & $\mathrm{Aub}$ & G3 & $\mathrm{Q} 2$ & C2 & Mi0 & $\mathrm{Fl}$ & An2 \\
\hline & Bwb & G3 & $\mathrm{Q} 2$ & $\mathrm{C} 2$ & Mi0 & $F 1$ & An2 \\
\hline
\end{tabular}

$\begin{aligned} * 4 & =>60 \% \\ 3 & =30 \text { a } 60 \% \\ 2 & =10 \text { a } 20 \% \\ 1 & =<10 \% \\ 0 & =\text { não determinado. }\end{aligned}$




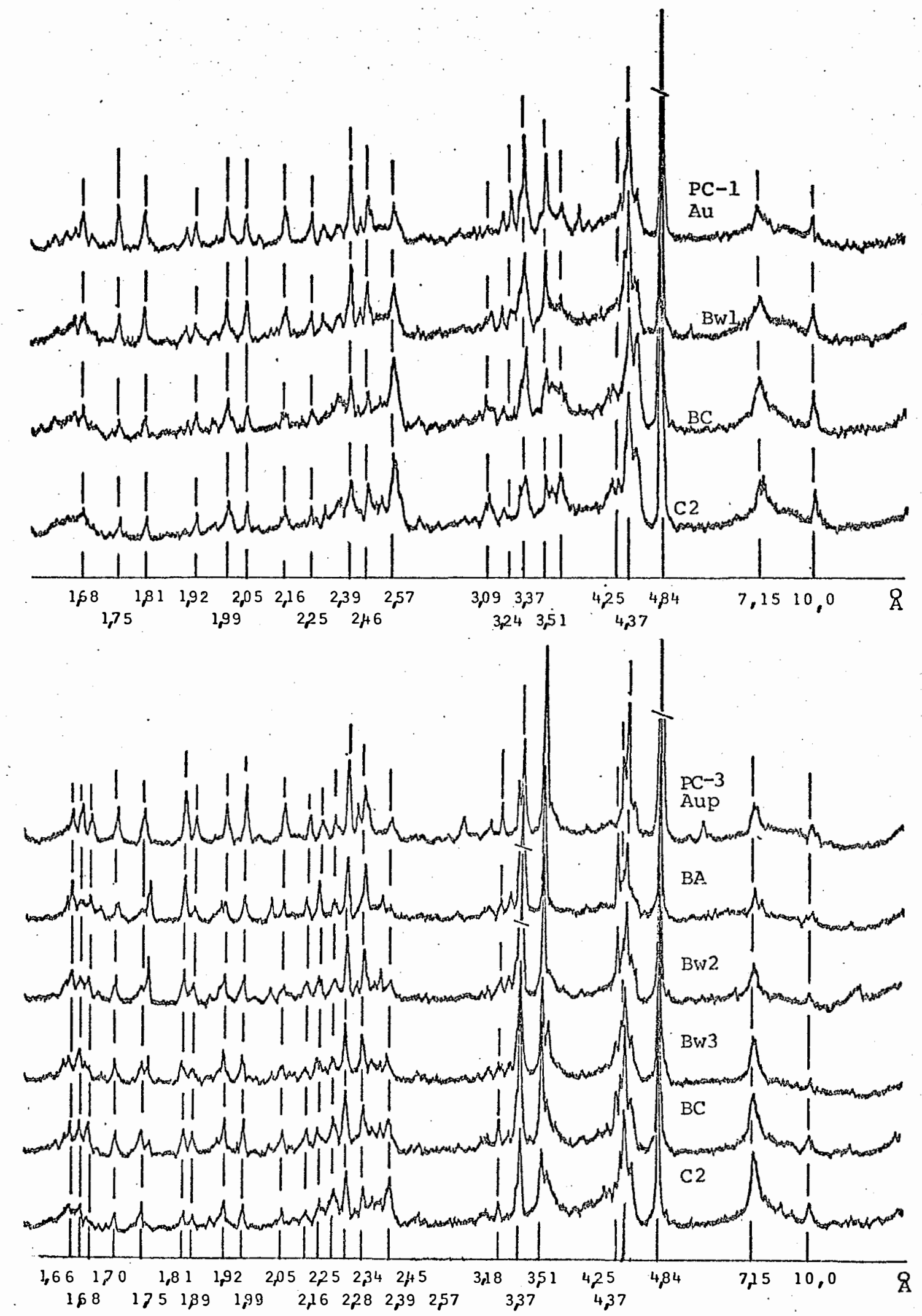

Figura 24 - Difratogramas de raios- $X$ da fração silte $(50-2 \mu)$ sem óxidos de ferro, dos perfis PC-1 e PC-3 da área I. 

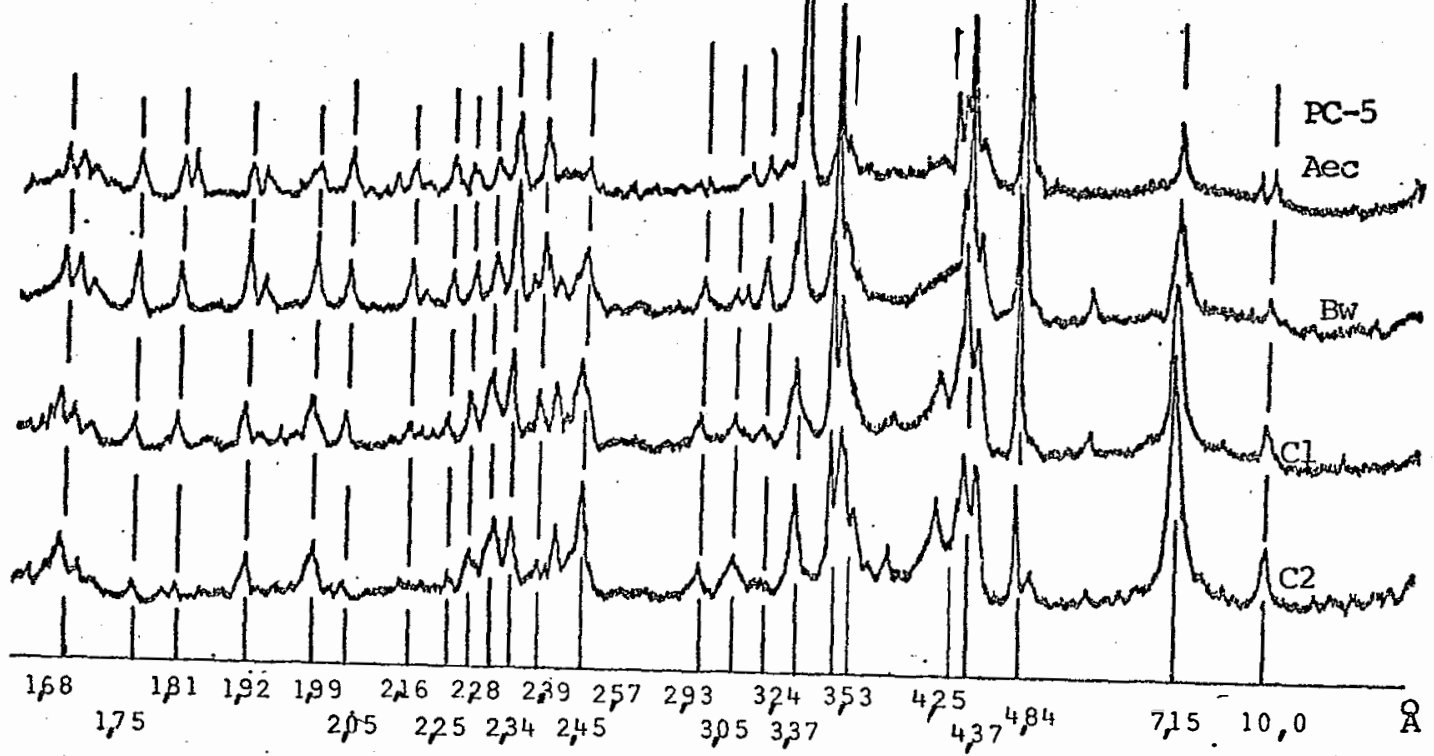
II)

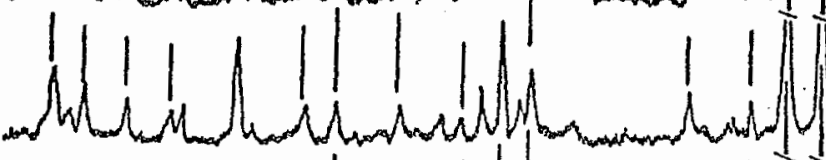
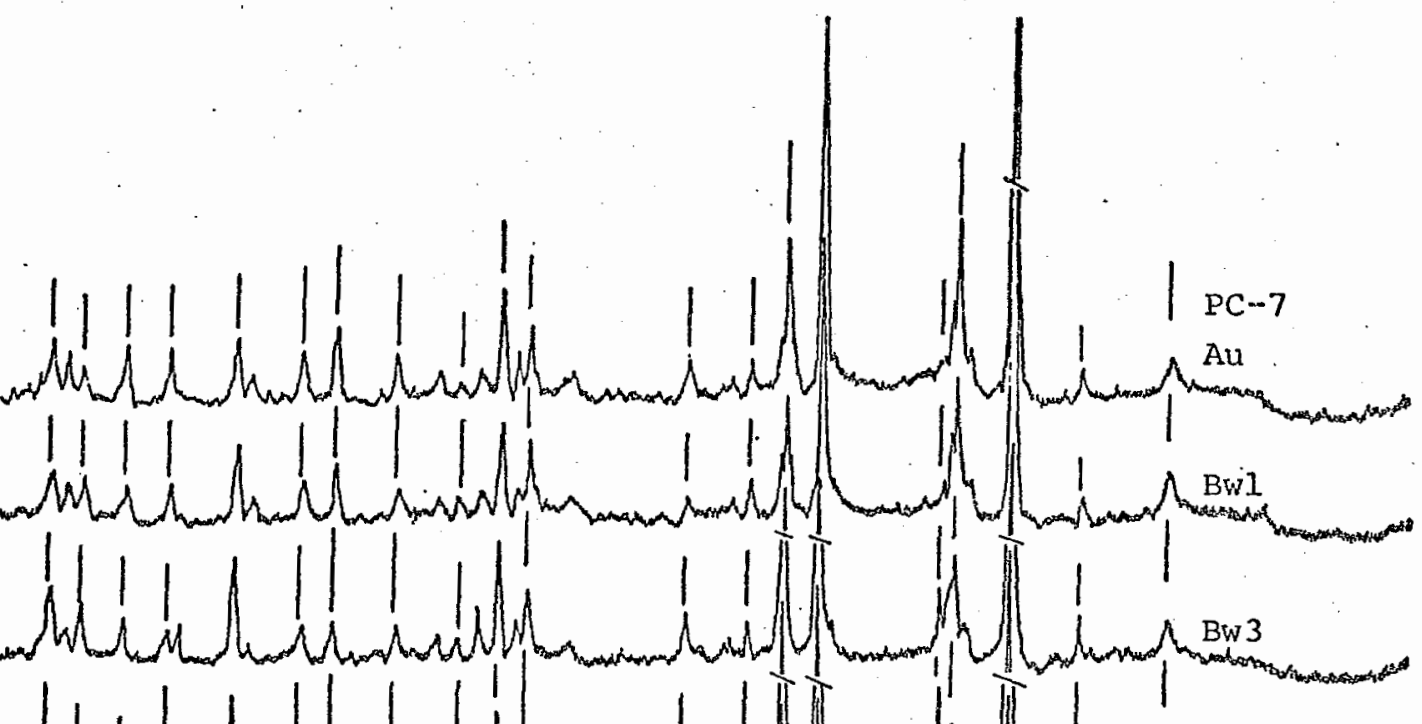

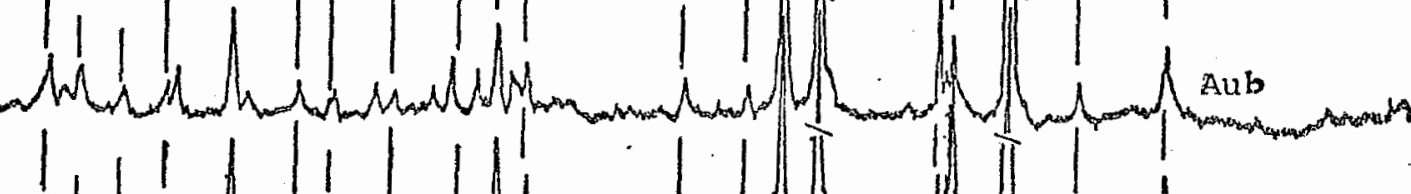

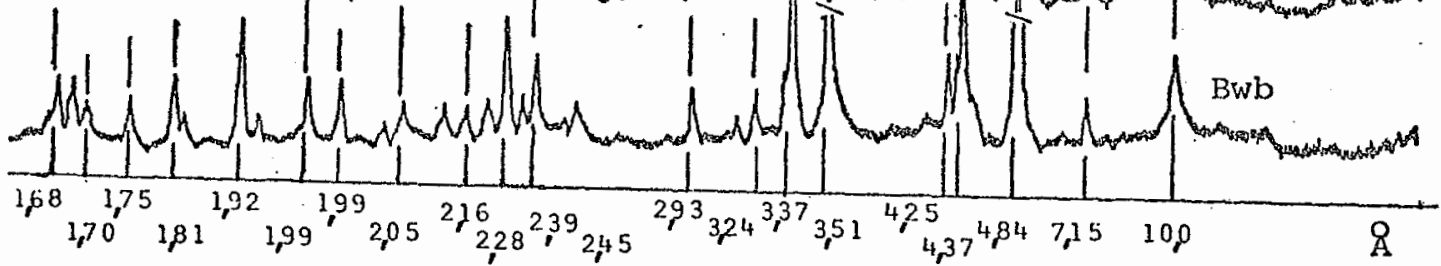

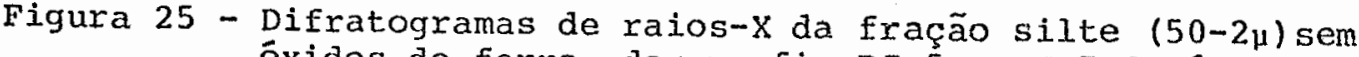
óxidos de ferro, dos perfis $\mathrm{PC}-5$ e $\mathrm{PC}-7$ da ârea II. 
A gibbsita presente na fração silte destes solos deve ter comportamento semelhante ao da fração areia, e, sendo também, considerada primāria, resultante da transforma ção direta de feldspato. o quartzo encontrado na fração silte também teria o mesmo comportamento e origem do observado na fração areia.

o quartzo na fração silte em geral decresce li geiramente com a profundidade, enquanto que a caulinita cresce no mesmo sentido. Tal comportamento parece estar relacionado com a formação de caulinita por ressilicatização da gibbsita primária, tendo a sílica amorfa como fonte principal de silica.

A mica encontrada nas frações areia e silte de alguns destes solos é uma mica secundāria originada também pe la alteração de feldspatos na presença de $\mathrm{K}^{+}$, uma vez que as rochas alcalinas: tinguaitos, fonolitos, lavas fonoliticas e foiaitos, que deram origem a estes solos não possuem mica em sua constituição.

5.4.4. Mineralogia da fração argila

A identificação mineralógica desta fração foi feita basicamente através de difração de raios-X. Os resulta dos quantitativos foram obtidos por análises químicas e DTA, conforme indica a Tabela 16. A fração argila é constituída principalmente de caulinita, gibbsita, material amorfos (alofanas), mica, venniculita, com hidroxila interlamelar, haloisita e quartzo (?).

As percentagens de materiais amorfos, obtidas por análi se química são significantes, e variam de 7 a $25 \%$, com teores mais eleva 


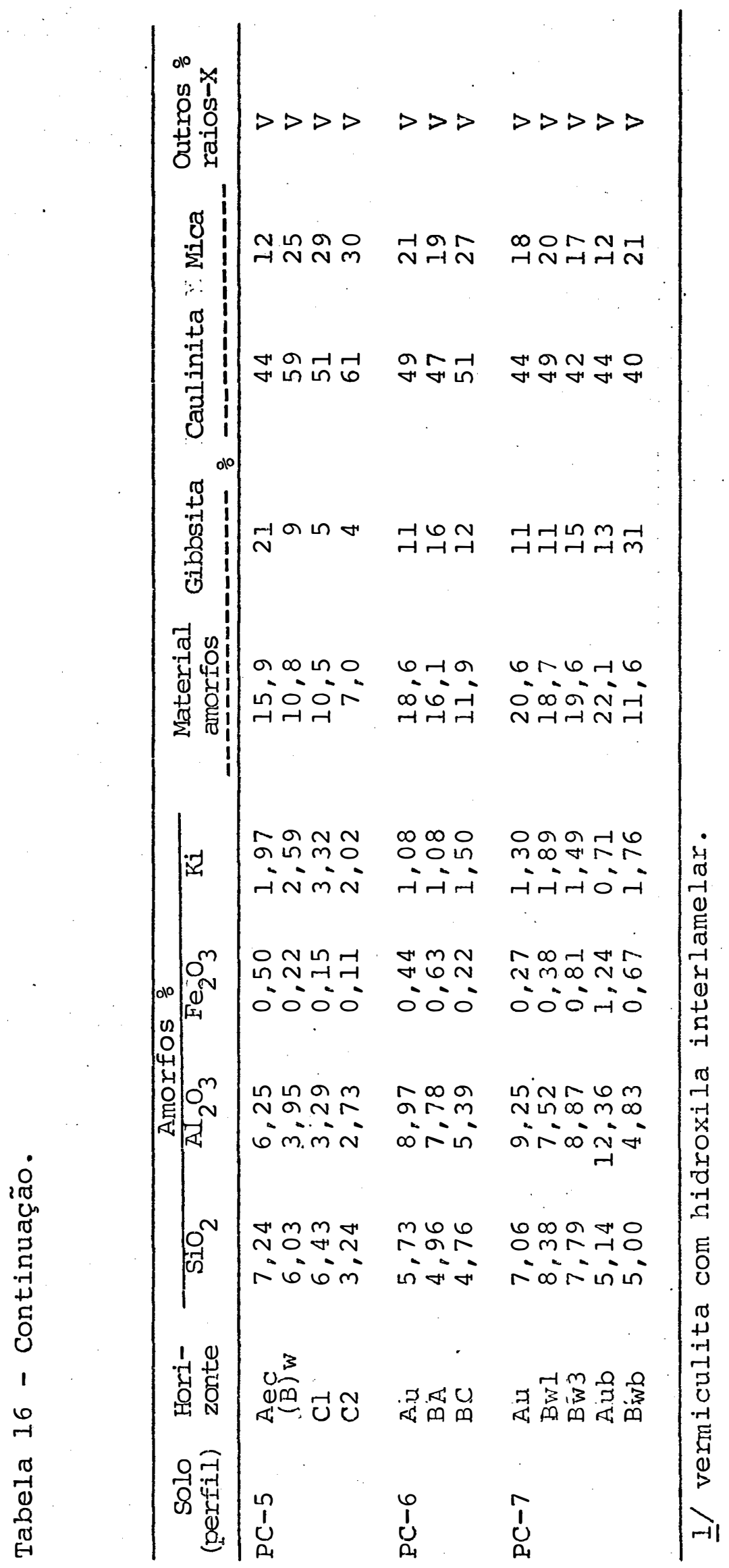


dos sendo observados nos perfis PC-1, PC-2, PC-4 e PC-7. Os teores altos de material amorfos nos perfis PC-1, PC-2 se deve a um menor grau de intemperismo, enquanto que, nos perfis PC-4 e PC-7, é atribuído à preservação dos materiais amorfos pela matéria orgânica, reduzindo a formação de gibbsita (WILSON, 1969).

Os teores de gibbsita determinados quantitativamente por DTA, variam nos solos de 1 (um) a 38\%, com os valores mais elevados nos perfis PC-3 e PC-4, demonstrando um grau de alteração mais intenso nestes solos. Os valores de maneira geral mantem-se constantes ou decrescem ligeiramente em profundidade. A caulinita por outro lado, apresenta tendência contrária. O aumento acentuado nos teores de gibbsita, observado nos horizontes BWb dos perfis PC-4 e PC-7,com 38 e $31 \%$ de gibbsita, respectivamente, contraria a tendência geral, por serem estes horizontes os mais intemperizados, sen do atribuído a ocorrência de solos enterrados. Enquanto que, os $21 \%$ de gibbsita no Aec do PC-5, é uma evidência de horizonte remanescente do colúvio.

De, acordo com os dados da Tabela 1.6 e os difra togramas de raios-X (Figuras 26 a 28), a-caulinita em geral é o mineral predominante nestes solos, sendo identificada na fração argila $(<2 \mu)$ saturada com $\mathrm{K}$ a $25^{\circ} \mathrm{C}$ pelos picos em 7,13 a $7,19 \AA$ e $3,57 \AA$, que desaparecem quando a amostra é aqueciida a $550 \AA$; com valores variando de 20 a $59 \%$, normalmen te apresentando um ligeiro acréscimo com a profundidade em al guns perfis.

A concentração percentual da mica varia entre 10 a $30 \%$ podendo chegar a $60 \%$, como no horizonte C2 do PC-2, porém, isto não é comum, com os valores normalmente crescendo com a profundidade. A mica foi identificada nos difratogra mas de raios-X de amostras saturadas com $K$ através do pico em 


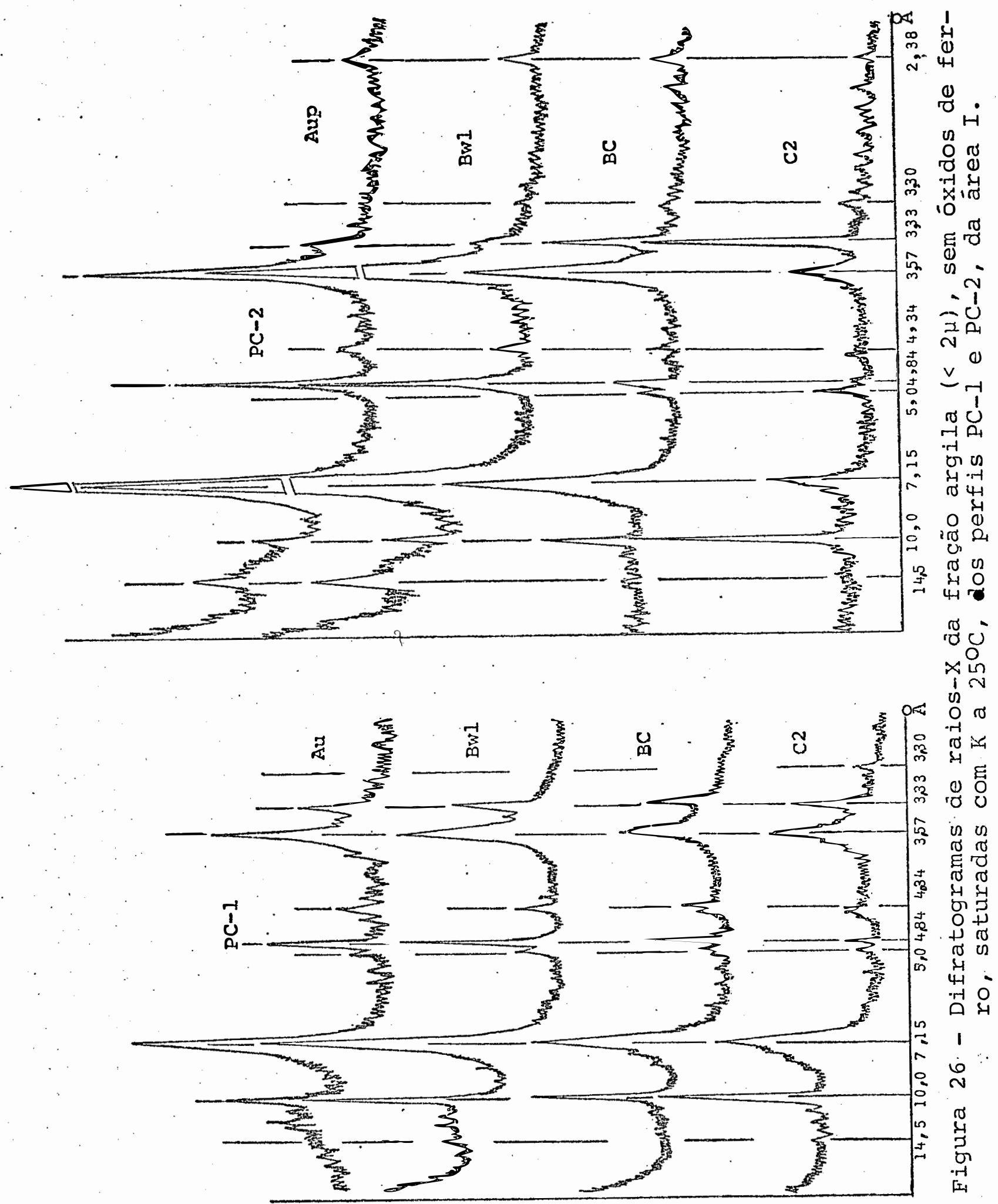




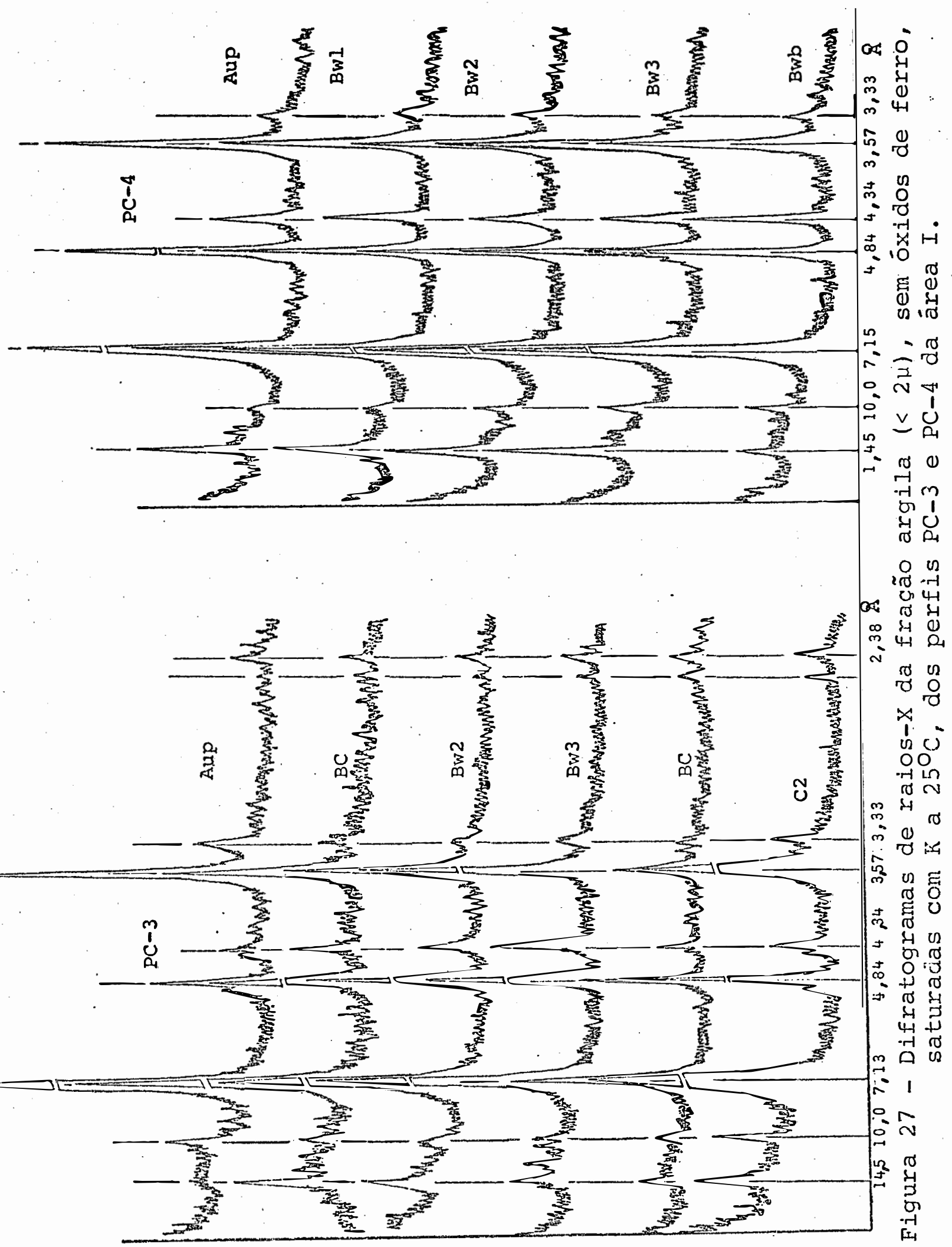



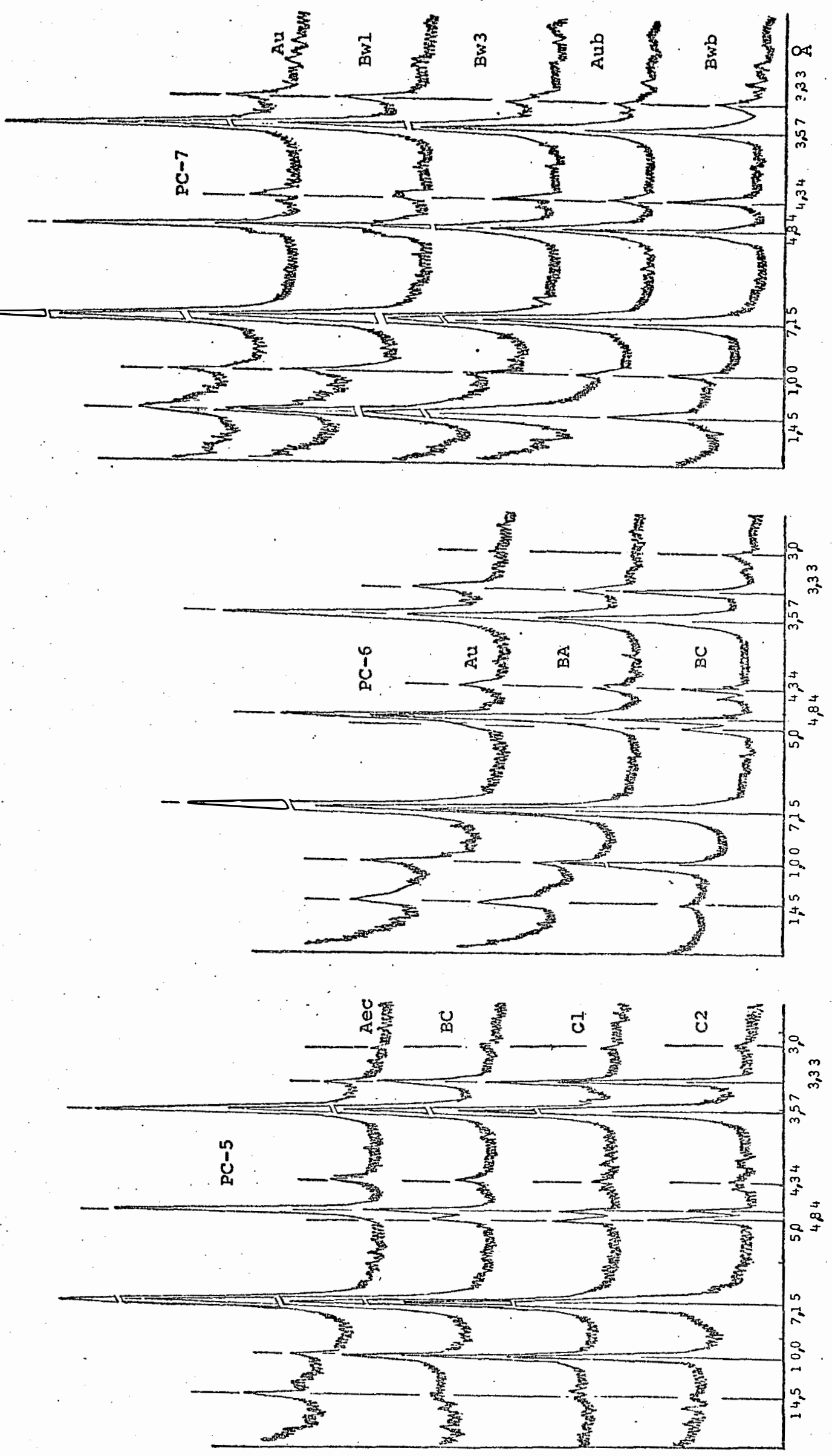
10 \& na amostra ao natural e a permanência deste pico após aquecimento a $550^{\circ} \mathrm{C}$. O teor elevado de mica (61\%) observado no horizonte $\mathrm{C}_{2}$ do perfil $\mathrm{PC}-2$, parece ser resultante de rocha alterada por metassomatismo hidrotermal (MONIZ, 1969). En quanto que, a conservação do teor mais alto de mica na superfície do perfil PC-3, pode ser atribuído ao aporte de material rico em mica.

Os teores de gibbsita em geral mais baixos nos horizontes superficiais destes solos e nos horizontes Bw3 e $\mathrm{Aub}$, respectivamente dos perfis PC-4 e PC-7, mesmo com teores altos de materiais amorfos e mais baixos de caulinita e de mi ca, deve-se à presença de teores mais elevados de matéria orgânica nesses horizontes, que têm a propriedade de estabele cer e prevenir a recristalização dos materiais amorfos a gibsita (WILSON, 1969).

A haloisita constatada nestes solos, foi obser vada atravês da microscopia eletrônica, ocorrendo em pequena percentagem, principalmente nos horizontes inferiores dos per fis $\mathrm{PC}-1$, PC-2 e PC-5.

Nos difratogramas de raios-X (Figuras 26 a 28) além dos picos referentes à caulinita, gibbsita e mica, também foram observados picos de menor intensidade na faixa de $10 \AA$ a 14 \& com presença mais significativa para o pjco de $14,4 \AA$. O mineral de $14,4 \AA$, não se expande quando glicolado, mas colapsa parcialmente para $10 \AA$, quando saturada com $\mathrm{K}$ e aquecida a $550^{\circ} \mathrm{C}$, sugerindo que o mesmo seja uma vermiculita com hidroxila interlamelar (Figura 29). A presença de vermi culita com hidroxila interlamelar nestes solos sugere a exi.stência de uma fase intermediária na alteração da micra em cau linita.

Em relação a composição mineralógica destes sô los há uma certa semelhança com os dados obtidos por MONIZ 


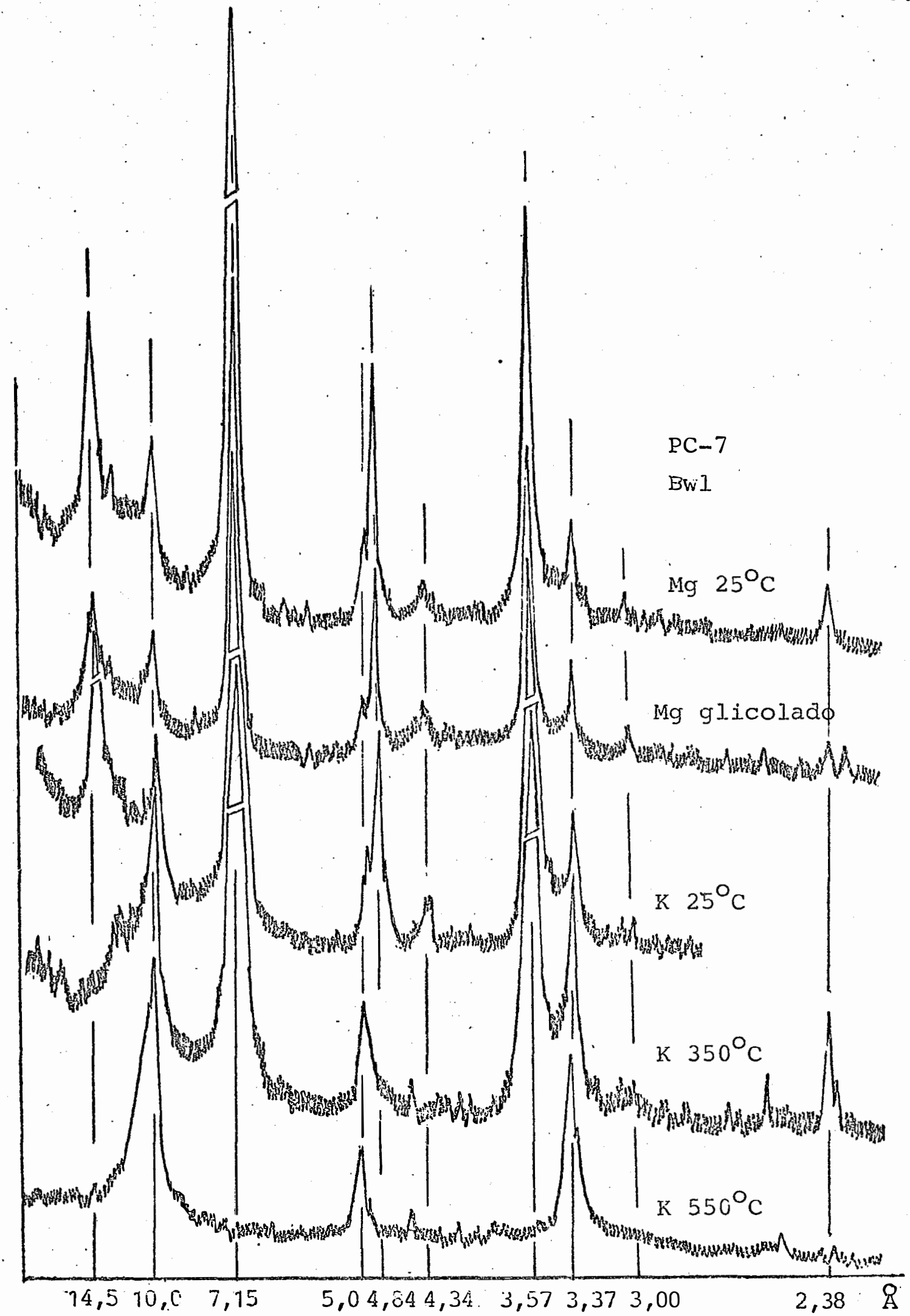

Figura 29 - Difratogramas de raios-X da fração argila ( $<2 \mu)$, sem oxidos de ferro, saturadas com Mg e glicoladas e com $\mathrm{k}$ e aquecidas, do horizonte Bwl. e do perfil $\mathrm{PC}-7$. 
(1969) e por ANTONELLO (1982) para solos desenvolvidos de rochas alcalinas do maciço alcalino de poços de Caldas e de Itá tiaia, respectivamente, assim como, para solos altamente intemperizados de outras áreas do Brasil oriundos de rochas não alcalinas (MONIZ e JACKSON, 1967; MONIZ e OLIVEIRA, 1974; ANDRADE et alii, 1974; DEMATTÊ, 1977; RODRIGUES, 1977; KAMPF e e KLAMT, 1978 e LIMA, 1979).

As tendências gerais observadas em relação as alterações mineralógicas são discutidas a seguir. As micas identificadas nestes solos, são secundárias e neoformadas. o decréscimo em seus teores, a medida que se dirige para a superfície e o aumento da caulinita nesta mesma sequência sugere transformações das micas para caulinita. Por dessilicati zação parte desta caulinita pode transformur-se em gibbsita, uma vez que a tendência de concentração dos valores deste mineral nos solos é ao contrário da caulinita. Neste caso forma-se a gibbsita II. Por outro lado é possível identificar uma gibbsita formada diretamente do intemperismo dos feldspatos como observado no estudo micromorfológico. Neste caso tem-se a gibbsita I ou gibbsita primária (GARDNER, 1972).

A presença de gibbsita primária e secundária, foram constatadas anteriormente na área de Poços de Caldas por WEBER (1959) e MONIZ (1969). ANTONELLO (1982) também observou estas duas categorias de gibbsita nos solos de Itatiaia.

A formação de gibbsita nos solos depende de condições ambientais e físico-químicas propícias, que podem ser resumidas segundo SIEFERMANN e MILLOT (1969) em duas condições essenciais, uma boa drenagem e um meio fortemente dessaturado.

HSU (1977) considera que a formação da gibbsita é governada pela concentração de Si e AI na solução do so10, resultante do intemperismo químico. A gibbsita forma-se rapidamente quando o $\mathrm{Si}$ é separado do $\mathrm{Al}$, pela lixiviação da 
sillica. Contudo, se a lixiviação torna-se menos intensa a concentração de $\mathrm{Si}$ pode gradualmente aumentar e recombinar com Al e formar caulinita. A formação direta de gibbsita da alte ração de alumuninossilicatos seria governada pela intensidade de lixiviação, a qual é afetada por outros fatorés existentes em Poços de Caldas como precipitação, temperatura, material de par tida, topografia, nível do lençol d.'água, vegetação e tempo.

A caulinita poderia ter se formado da alteração direta de minerais primários, sendo o mais provãvel é que tenha se originado da transformação da mica e da ressilicificação da gibbsita primária. MONIZ (1969) estudando a mineralogia de a gilas de poços de Caldas atribuiu a formação de caulinita e gibbsita pela alteração de feldspato, assin como, a ressilici ficação da gibbsita e alteração da mica para formar caulinita.

A formação de mica nestes solos seria devido a alteração de feldspatos, que é controlada pelo $\mathrm{K}$ disponível no material primário. A alteração do feldspato em mica, sendo controlado pelo conteúdo de $\mathrm{K}_{2} \mathrm{O}$ do material primário, no caso de rochas alcalinas (cerca de $7 \%$ de $\mathrm{K}_{2} \mathrm{O}$ ) formará um alto conteúdo de mica secundária, como pode ser verificado no h. -izonte C do perfil PC-2. MONIZ e JACKSON (1967) e MONIZ (1969) têm observado a presença de mica em solos desenvolvidos de material de partida sem mica primária., atribuindo a origem da mesma a partir da alteração de feldspatos. MELFI e GIRANDI (1962) observaram em secções finas de rochas alteração de feldspatos em mica. A alteração da mica em caulinita, dar-se-ia pela liberação de $K$ e posterior dessilicatização, se gundo BATES (1960).

A origem da vermiculita com hidroxila interlamelar nestes solos seria devido a precipitação de políme ros de alumínio nas intercamadas da vermiculita. 
MOLLER e KLAMT (1982) têm atribuido a possibilidade da precipitação de polímeros de Al nos espaços interla minares de filossilicatos em solós ácidos e bem drenados, reduzindo a capacidade de troca e conferindo uma maior estabili dade (LE ROUX, 1973). Tal fato explica a persistência desses minerais nestes solos.

A presença de vermiculita com hidroxila interlamelar nes tes solos seria uma fase intermediária na alteração da mica secundária em caulinita e, posteriormente, em gibbsita através do processo de dessilicatização gradual e intensiva, sendo este o principal processo de alteração atribuido por JACKSON e SHERMAN (1953) e JACKSON (1964) para solos tropicais altamente intemperizados.

Segundo Pedro (1966) citado por ANTONELLO (1982) sob condições de intensa lixiviação, os limites de solubilidade dos minerais silicatados não são atingidos e a evo lução pode levar a formação de gibbsita, antes da alteração total dos feldspatos. Isto parece explicar a coexistência de gibbsita primária e mica secundária nestes solos.

MONIZ (1969) atribuiu a seguinte sequência de alteração para as rochas alcalinas de Poços de Caldas: rochas alcalinas (feldspato) $\rightarrow$ mica $\rightarrow$ caulinita e material amorfos + gibbsita. Contudo, a mesma não seria suficiente para ex plicar as alterações ocorridas nos materiais dos solos, tendo sido constatada mais de uma sequência de alteração nestes solos:

Feldspato $\rightarrow$ mica $\rightarrow$ vermiculita com hidroxila interlamelar $\rightarrow$ caulinita e materíal morfós $\rightarrow$ gibbsita II (gibbsita secundária) Feldspato $\rightarrow$ caulinita e material amorfos $\rightarrow$ gibbsita II 
Feldspato $\rightarrow$ gibbsita I - $(+\mathrm{Si}) \rightarrow$ caulinita e material amor fos $\rightarrow$ gibbsita II.

Tomando-se a gibbsitá como Indice de intemperismo, observa-se que os solos correspondentes aos perfis PC3 e PC-4, seriam os mais intemperizados. Considerando-se os - teores de gibbsita (Tabela 16) nos horizontes Ewb dos perfis PC-4 e PC-7, respectivamente, indicam uma maior alteração nes ses horizontes em relação ao perfil como um todo, demonstran do a existência nesta região de solos mais antigos.

\subsection{Micromorfologia}

A descrição micromorfológica de horizontes e perfis selecionados estão indicados no Apêndice II. De maneira geral entre os perfis bem desenvolvidos e profundos, não há muita variação nas características micromorfológicas, o que evidencia uma uniformização dos processos pedológicos.o PC-5, perfil cascalhento, resume grande parte da história da formação destes solos.

o esqueleto é constituído quase que essencialmente de feldspato e quartzo, porém em pequena quantidade motivado principalmente pela natureza da rocha e textura argilo sa destes solos, como também pelo avançado grau de intemperis mo. Concreções ferruginosas da mais variadas formas e tama nhos são de ocorrência comum em todo o perfil, com ligeiras concentrações em determinados locais do perfil, principalmente nas encostas onde a presença de cascalheiras é comum.

A ocorrência de feldspatos nestes solos deve se à herança do material de partida, rico neste mineral. Por outro lado, a sua persistência, mesmo nos paleossolos, é deví 
do a proteção dada pelos óxidos de ferro e alumínio, circundan do-o (Figuras 30 e 32 ).

As feições pedológicas são abundantes e repre sentadas essencialmente por: (1) nódulos de ferro (Figuras 34, 35 e 36), de gibbsita (Figura 34) e ferri-gibbsiticos, dissemi nados em todos os perfis, com concẹtrações nas cascalheiras, e de tamanho e forma extremamente variados; (2) poucos argilans (Figuras 36 e 39), ferri-argilans e grande quantidade de sesquans (Figuras 31,34 e 35 ), tanto de segregação como os formados ao redor dos grãos do esqueleto e nódulos do solo; (3) pre sença de sesquans nos canais (Figura 35) e fraturas do esquele to em alteração (Figura 30 ); (4) cristalaria de gibbsita (Figuras 34 e 351 e (5) papulas em pequena quantidade. As fissuras presentes são resultantes da retração do solo, principal mente nos horizontes mais inferiores (Figura 35). Nos horizon tes mais superiores os vasios são representados principalmente por canais.

Os argilans presentes são mais de segregação do que formados por iluviação. Neste caso os horizontes estuda dos não seriam considerados argílicos sob o ponto de vista micromorfológico.

A matiz do solo é essencialmente argilasépica a insépica nos horizontes superficiais de cor bruno a bruno ama relado (Figura 35 ) numa distribuição quase sempre porfiroesque lética. Os horizontes inferiores possuem matriz do solo latisépica vermelho amarelado ou mesmo cinza claro numa distribuição porfiroesquelética. Em alguns casos ela é insépica ou mes mo argilasépica. Os horizontes $C$ possuem matriz essencialmente latisépica (Figura 38). A estrutura plásmica latisépica, de ocorrência predominantemente nos horizontes mais inferiores, na 


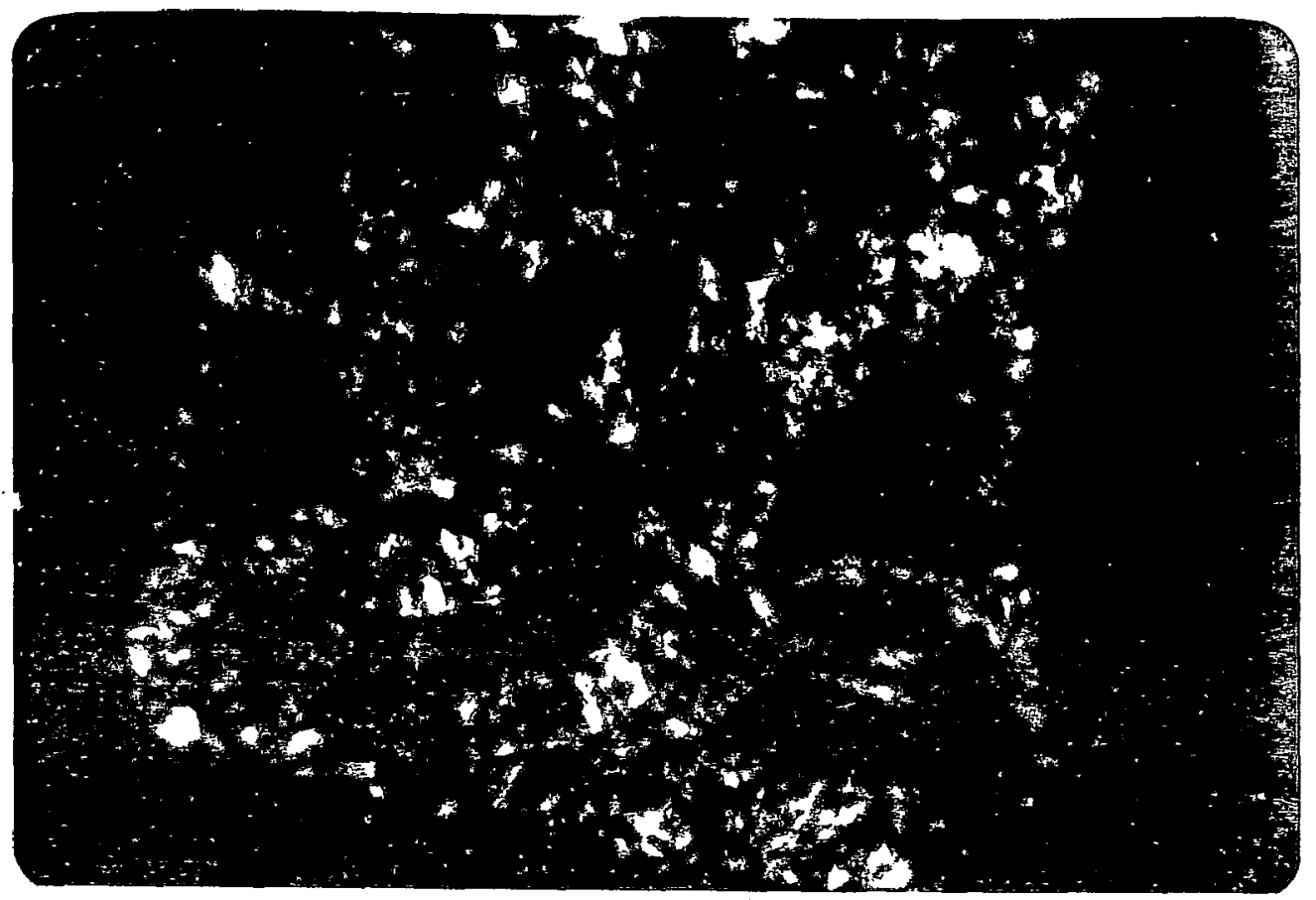

Figura 30 - Perfil PC-l. Horizonte Bwl (nicois x). Mineral primário (feldspato) parcialmente alterado. Nota-se neo formação de gibbsita (mineral esbranquiçado) e cau= linita, assim como o preenchimento das fraturas com sesquans.

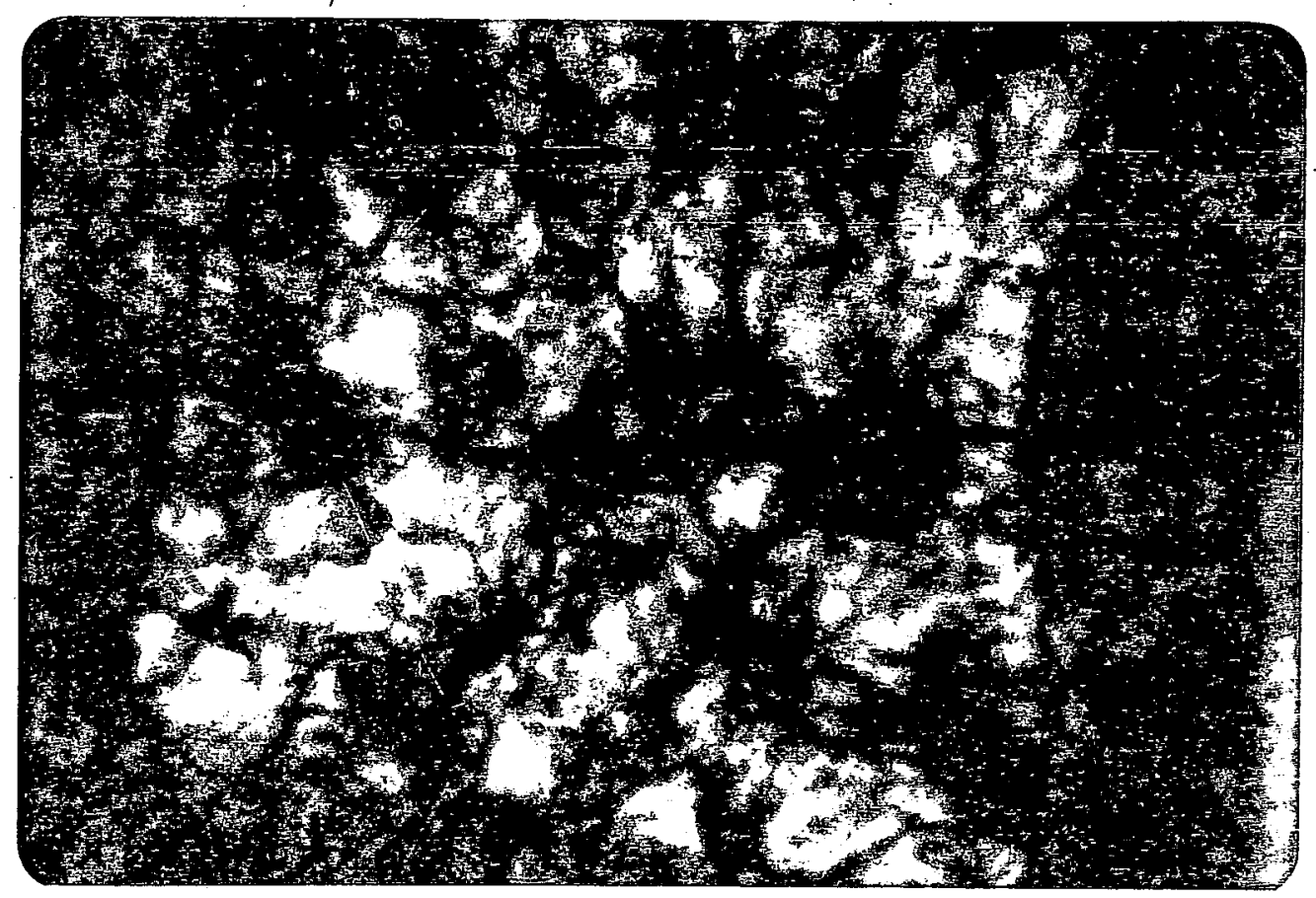

Figura 31 - Perfil PC-1. Horizonte Bwl (luz paralela). O mesmo mineral acima em contacto com a matriz. Observa-se tanto as fraturas do mineral como as fissuras (planes) parcialmente preenchidas por sesquans. Além dis so, a continuidade das fraturas do mineral com a $\bar{s}$ fissuras da matriz, ilustra a herança da estrutura.o mineral está circundado por sesquans. 


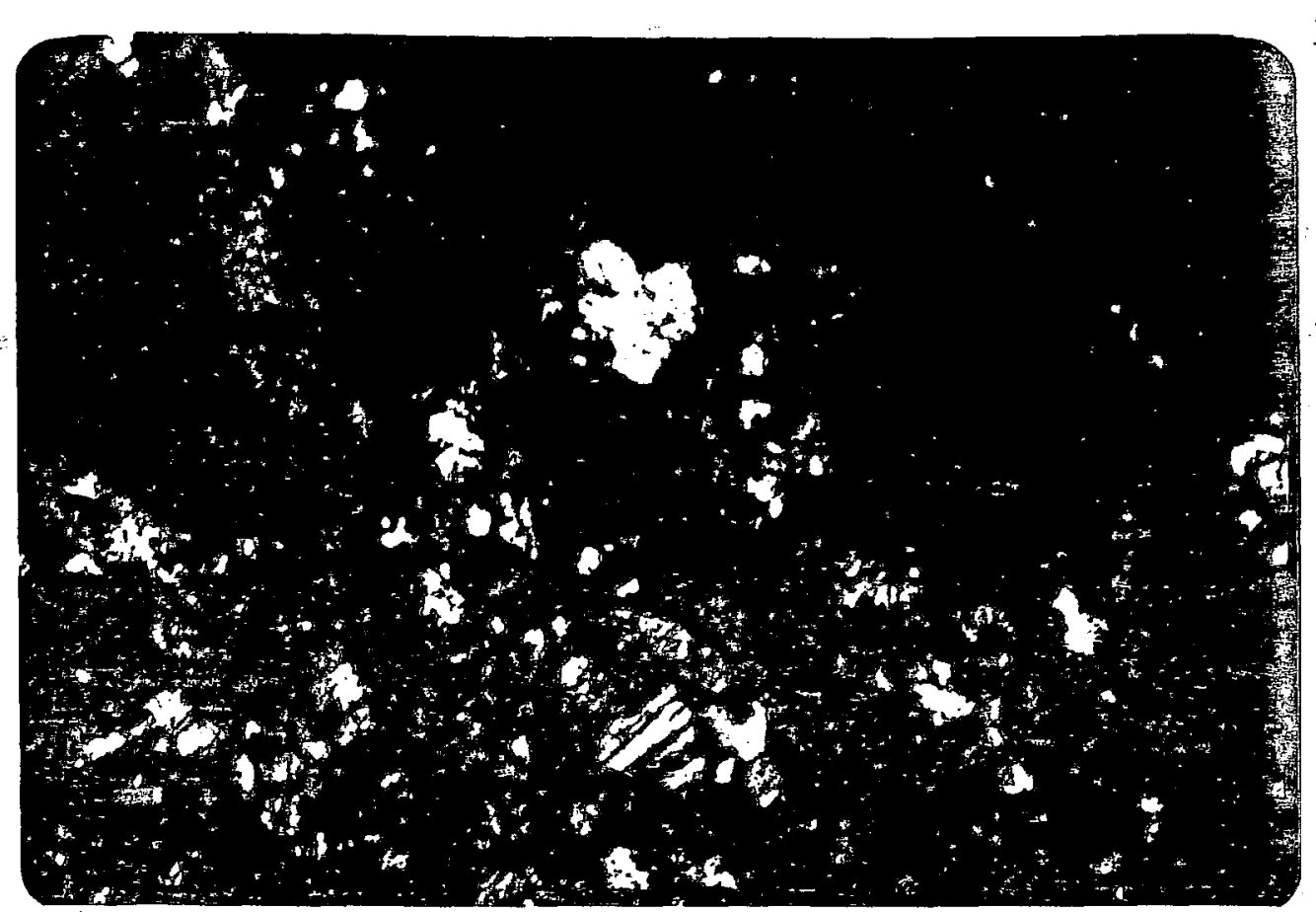

Figura 32 - Perfil PC-5: Horizonte Aec (nicois X). Canto superior direito: canal preenchido por gibbsans (linha fina', quebrada e branca). A área escura envolvendo o gibbsan è de sesquióxidos opacos. Área central: grânulo de feldspato parcialmente alterado e circundado por óxidos de ferro-aluminio, preservando-o.

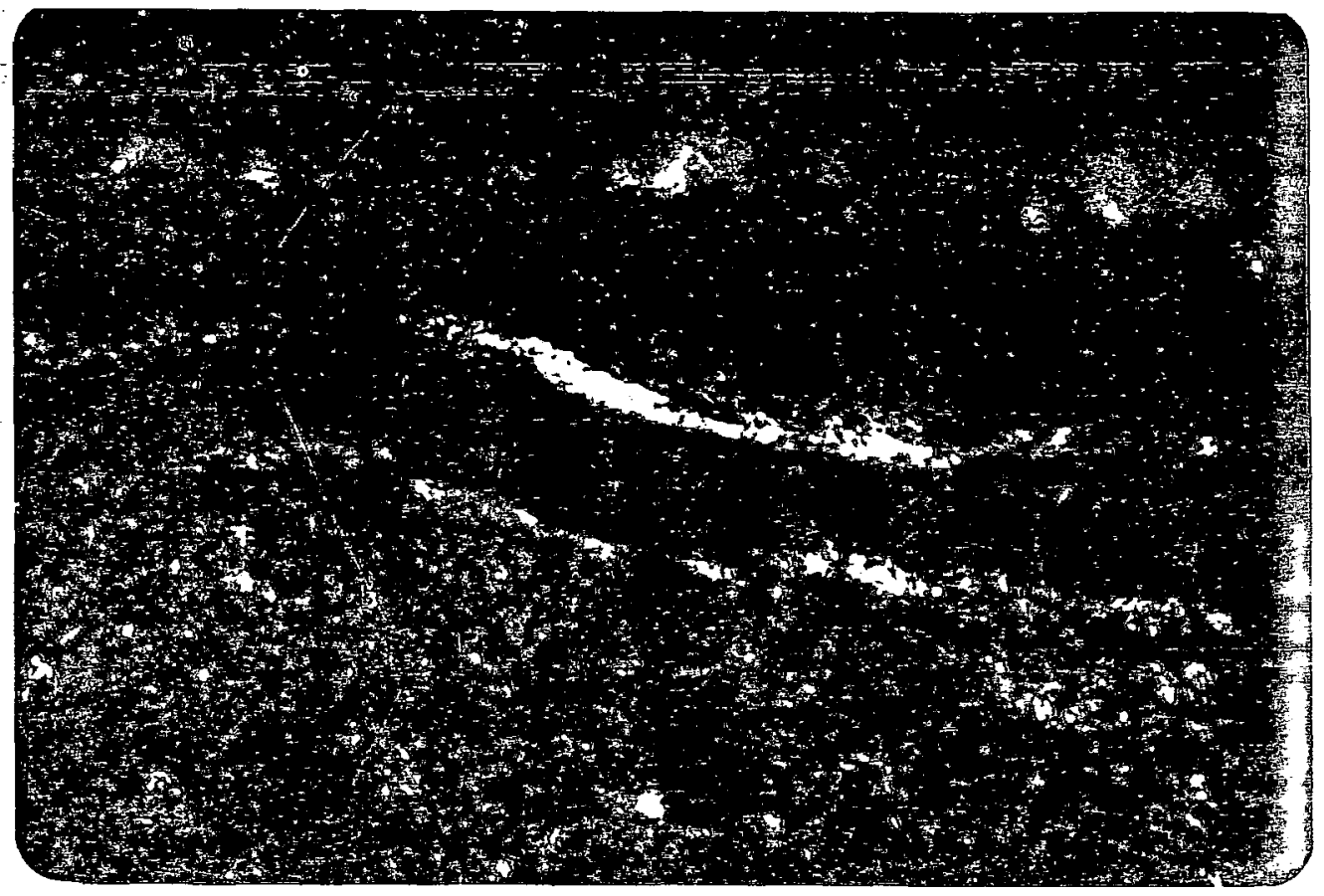

Figura 33 - Perfil PC-l. Horizonte Cl (nicois X). Área central cor tando toda a foto: canal com deposição de gibbsans. As pontuações claras na matriz são representadas por microcristais de gibbsita. 


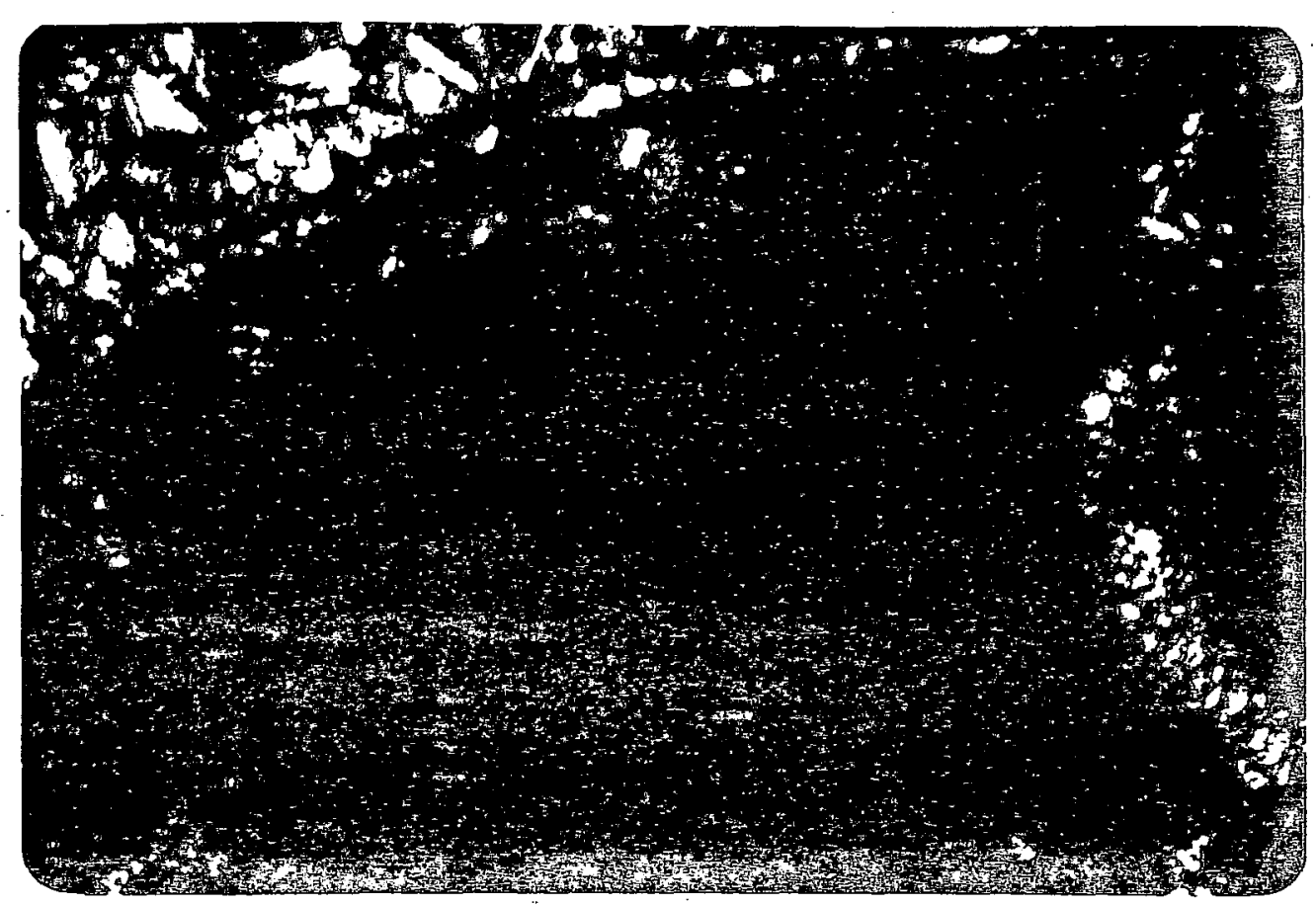

Figura 34 - Perfil PC-5. Horizonte Aec (nicois X). Parte central: nódulo de ferro. Parte superior esquerda: c̈ristalaria de gibbsita, separada do nódulo de ferro pelo sesquan e pouco de concentração plasmática. Parte lateral direita: canal cruzando toda a extensão do nódulo e pre enchido parcialmente por gibbsita.

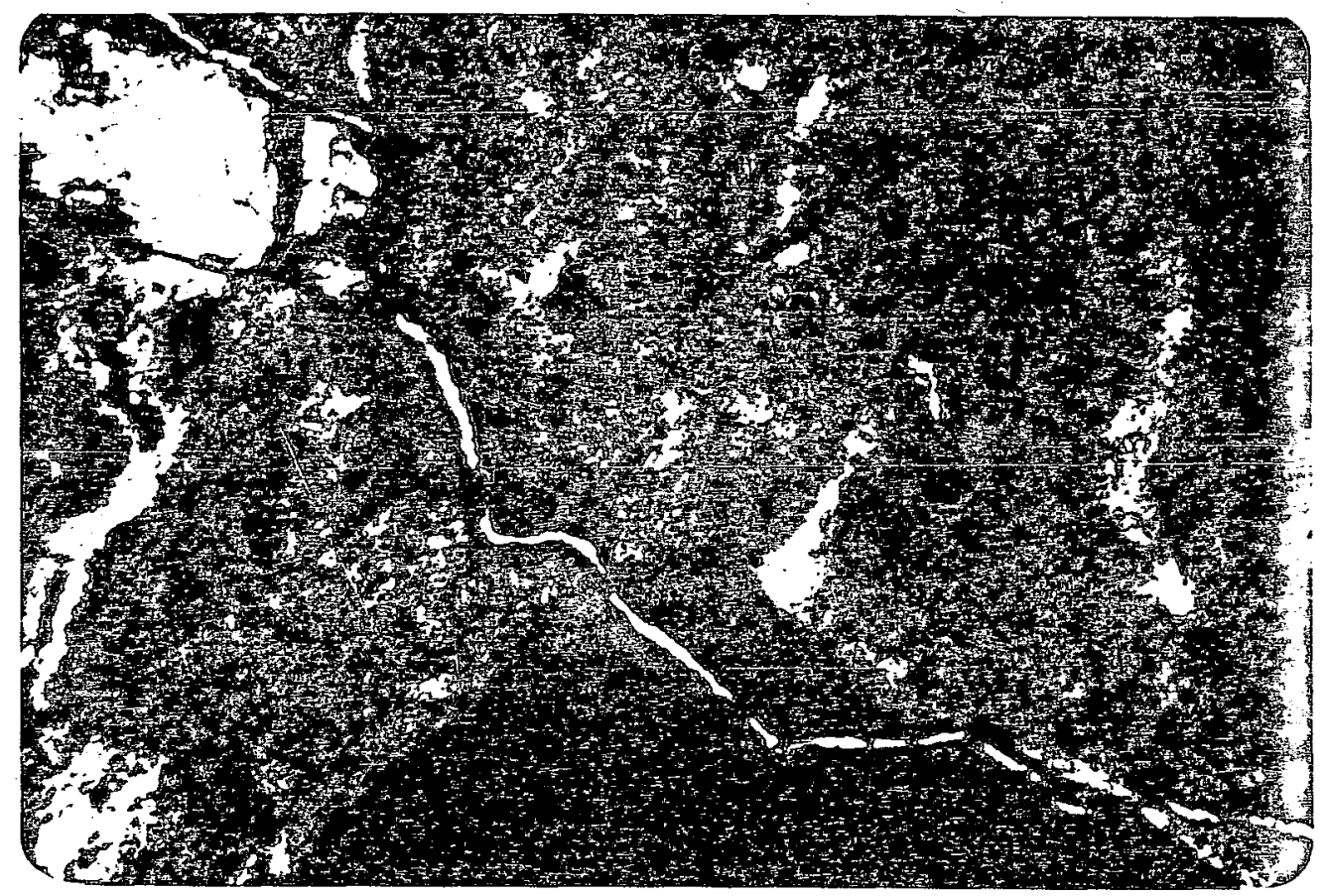

Figura 35 - Perfil PC-6. Horizonte Bwl (luz paralela). A fissura parcialmente preenchida por sesquans liga o grânulo de quartzo com a concreção de ferro cortando-a. Notase além dos poros e finos argilans formação de microa gregados. O esquelo é circundado pelo sesquan. 


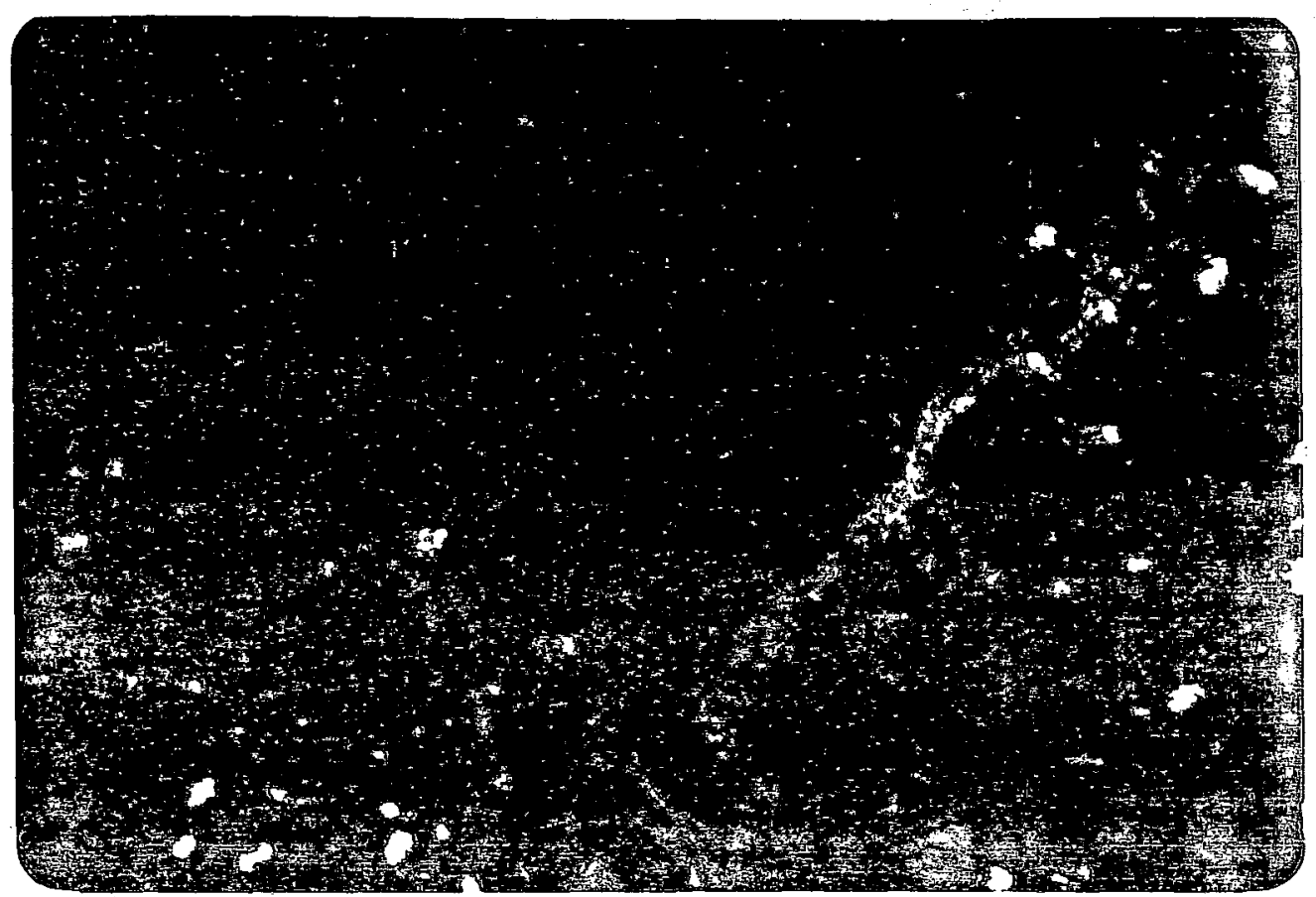

Figura 36 - Perfil PC-5. Horizonte (B)W (nicois X). Contato entre o nódulo e a matriz do solo. Observa-se no contato a ocorrência de fissuras associada com sesquans e argilans. Na matriz do solo os minerais claros são cris tais de gibbsita circundado por concentração plasmáti ca.'

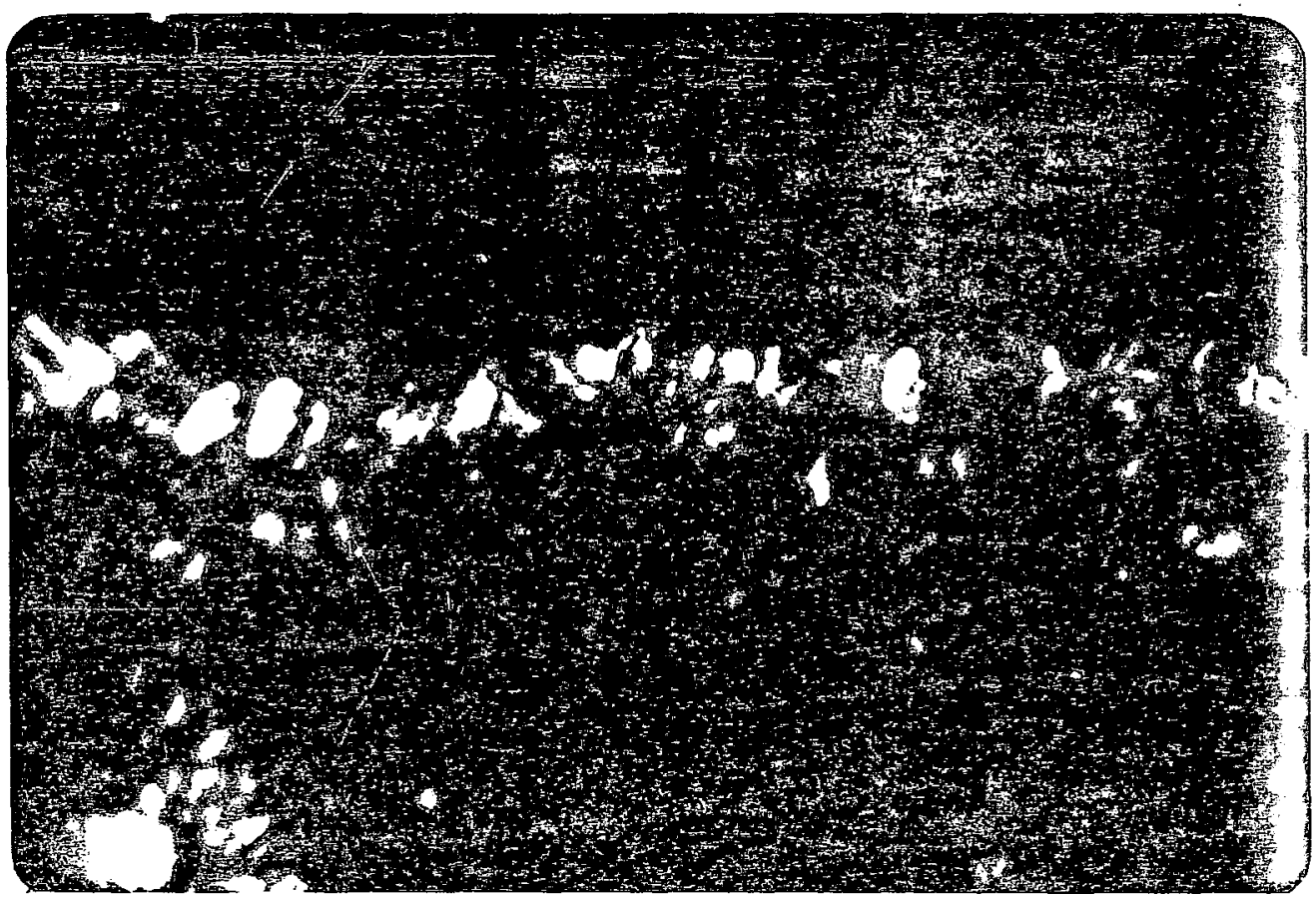

Figura 37 - Perfil PC-5. Horizonte Aec (nicois X). Parte central em toda extensão da foto: cristalaria de gibbsita.Separando a cristalaria da matriz ocorre sesquans. Parte inferior esquerda: vazio preenchido por gibbsita em forma de nódulo. 


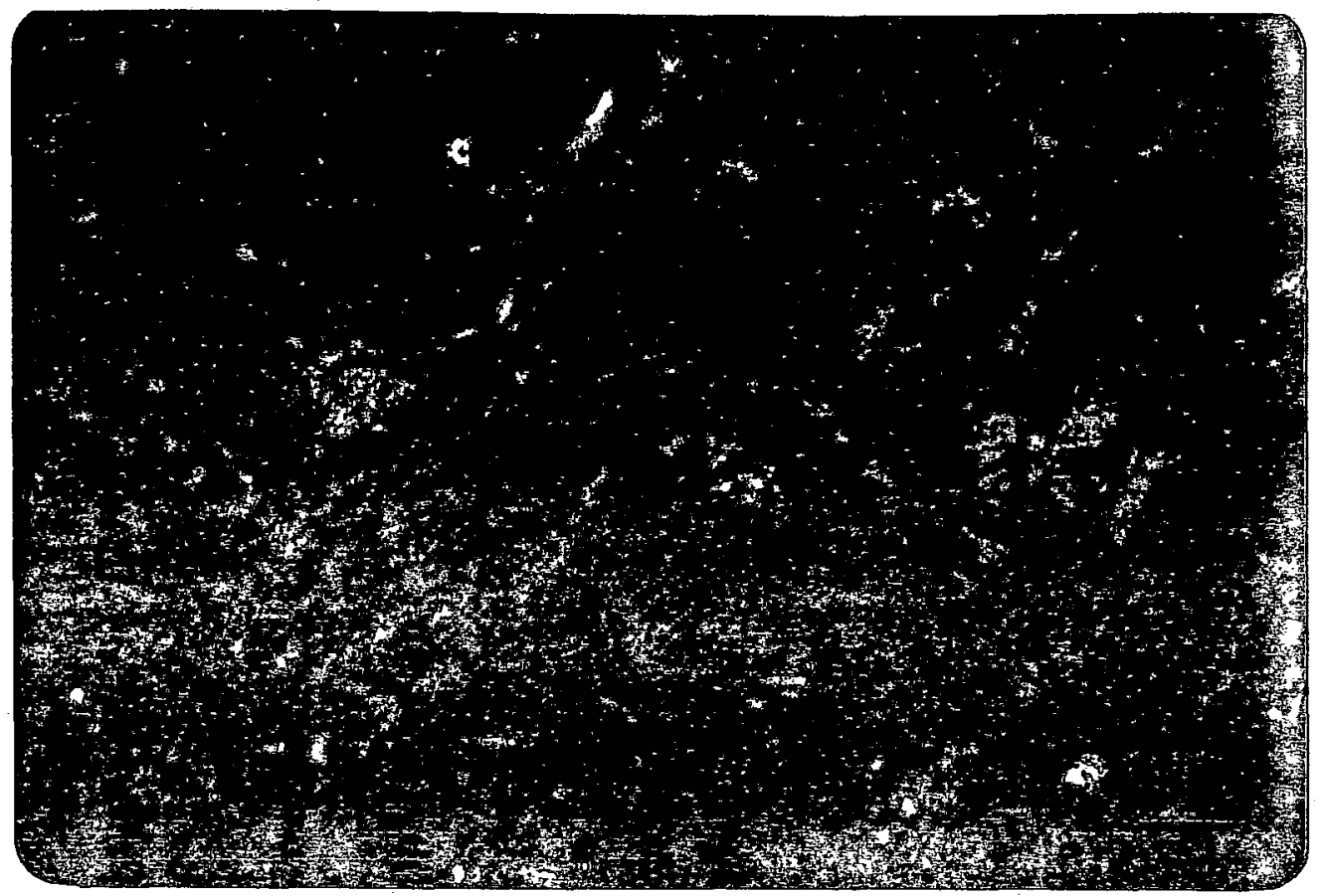

Figura 38 - Perfil PC-2. Horizonte Bw2 (nicois X). Aspecto geral da estrutura plásmica latisépica. As fissuras (pla nes) estão preenchidos por silans.

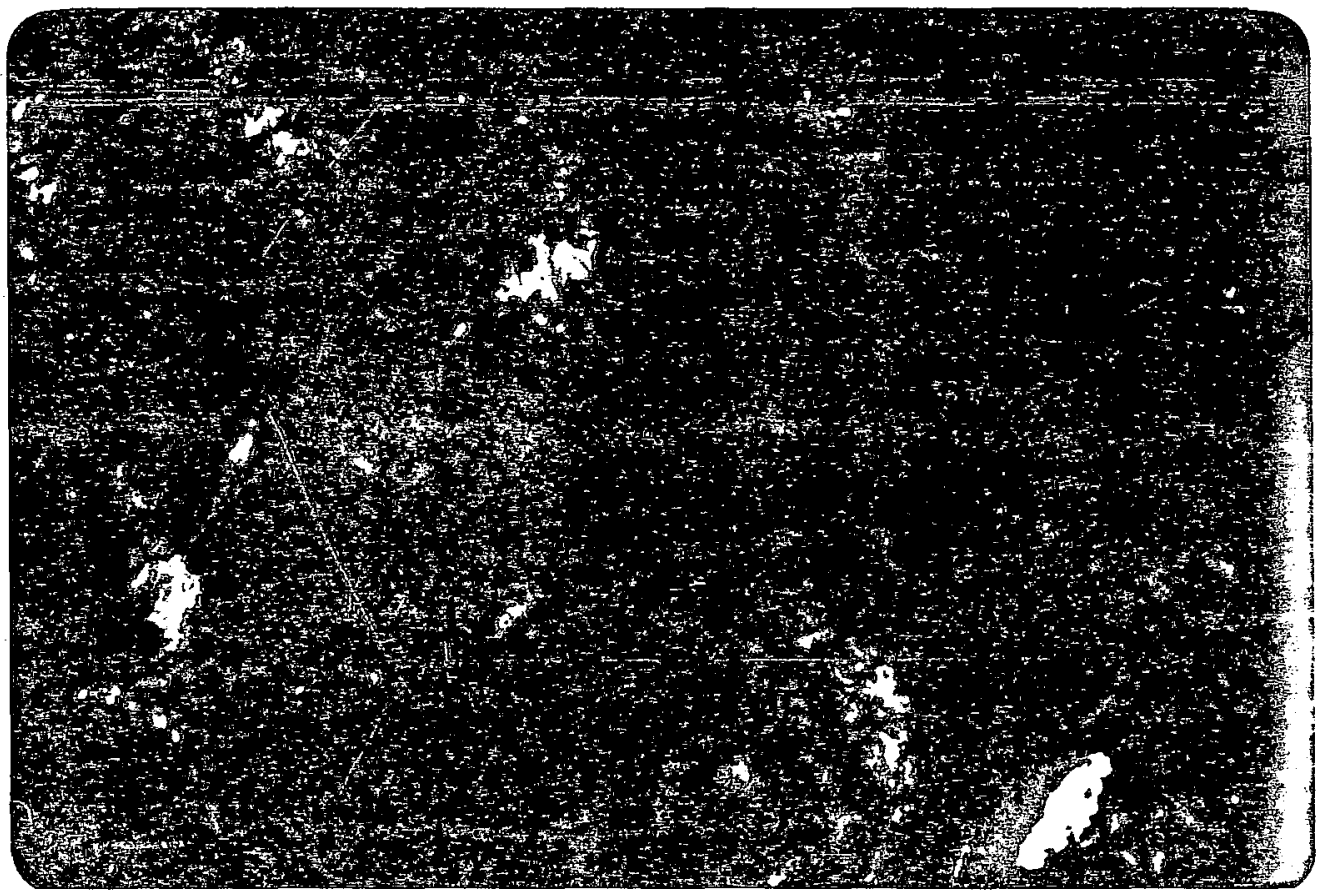

Figura 39 - Perfil PC-5. Horizonte Cl (nicois X). Combinação plas mâtica representada por argilans (tons amarelados). Parte inferior direita: pequeno vazio preenchido por gibbsita. 
da mais é do que uma herança do intemperismo da própria rocha. A Figura 31 ilustra a estrutura do material de origem sendo passada para o solo. A medida que se dirige para a superfí cie a estrutura plasmática tende a ficar menos orientada e mais asépica, motivada pela perda de orientação plasmática a medida que o intemperismo evolui (ESWARAN, 1972).

A estrutura isótica ou ligeiramente undulica somente foi constatada nos horizontes Aub enterrado do perfil PC-7. A grande isotropia mostrada por este horizonte se deve a presença de matéria orgânica e redistribuição dos óxidos que inclusive preservam a estrutura.

A ausência da estrutura isótica ou mesmo undulica da maioria dos horizontes estudados diferem dos solos ver. melhos ou brunos, essencialmente argilosos, classificados como latossolos. Tal ausência se justifica devido a grande ani sotropia apresentada por estruturas microcristalinas da gibbsita,presente abundantemente em todos os horizontes estuda dos.

o processo inicial do intemperismo é representado pelo ataque ao feldspato. Neste processo inicial, formase um gel de alumínio que pode se transformar em gibbsita (ou gibbsita I), principalmente por dessilicatização. Tal fato é comprovado através da ocorrência de gibbsita circundando os feldspatos (Figuras 30 e 32 ). Ao mesmo tempo a concentração deste gel de alumínio ou mesmo gibbsita nas cavidades e fen das de matriz, desenvolvem os nódulos gibbsiticos, que podem, muitas vezes, formar cristalarias gibbsiticas. Quando a quantidade dos nódulos gibbsỉticos é grande, assim como, dos microcristais de mesma natureza disseminados internamente na es trutura plásmica, hã uma modificação nesta estrutura, dando 
do origem a uma estrutura crística ("crystic"). A Figura 34 ilustra esta estrutura, assim como, neoferrans ao redor do es queleto, devido principalmente a processo de dissolução.

A ferruginização do plasma teve início nesta fase de intemperismo primeiramente difundido em toda a estrutura, com concentrações mais avermelhados e depois localizada ao redor do esqueleto e vasios e mesmo na própria matriz (Figura 32). A concentração do ferro, da mesma maneira que o alumínio, deram origem aos nódulos de ferro (hematíticos e goethíticos) (Figuras 34, 35 e 36), assim como, nódulos ferrigibbsiticos ou gibbsíticos (Figura 37 ). A concentração de tais nódulos ocorre principalmente nas encostas ingremes da área, região de segregação do ferro para formação de lateri tas.

A matriz do solo, essencialmente argilosa (Figua 35) é constituída principalmente por caulinita, que por sua vez deve ter sido formada por cristalização da solução con centrada nos vazios de diferentes origens ou resultante de al terações pseudomórficas do material de origem (Figura 30). A associação de caulinita com microcristais de gibbsita, alta mente anisotrópica, resultou na formação de uma estruturá plas mática sépica, anisotrópica e não isótica como a maioria dos oxissolos.

os grânulos de quartzo, em geral corroídos e fraturados, são preenchidos por sesquans (Figura 35). A ocor rência deste material não está restrito apenas ao esqueleto. $\bar{E}$ comum vê-los associados aos vasios (Figura 36) e circundando os grânulos do esqueleto (Figura 35) (neoferrans), como tam bém, em agregados irregulares (Figura 31). Na Figura 35 observa-se a ocorrência de esqueleto associado com sesquans e 
o vasio indicando uma dissolução do quartzo posterior à ferruginação.

Devido as oscilações climáticas mais recentes parte da superficie original foi dissecada e o vale preenchido por novo material. Tal material, previamente intemperizado, parece ser da mesma natureza que o anterior, visto que suas caracteristicas micromorfológicas são bastante semelhantes. Transforma ções continuas e progressivas continuaram neste novo material. Tal transformação afetou tanto a estrutura plásmica como a com posição mineral, resultando numa redistribuição dos óxidos, de créscimo no esqueleto e aumento da caulinita e gibbsita por neoformação e preenchimento de volumes (formando nódulos gibbsíticos (Figura 34).

Com o intemperismo agudo, parte da caulinita, por dessilicatização, transformou-se em gibbsita. A formação de gibbsans frequente nas lâminas (Figuras 32, 33 e 34) está associada ao processo de remoção da sílica, principalmente da caulinita, pois esta é o principal constituinte do plasma do solo. A sílica removida pode depositar-se em vasios ou mesmos canais dando origem aos silans (Figuras 38 e 40 ).

A presença de concreções ferruginosas em determinadas posições da encosta deve-se essencialmente a remoção do ferro, por intemperismo, nas āreas mais elevadas e num ambiente redutor. E comum a ocorrência na ārea, de paleodrenagem, responsável pela oscilação do lençol freático e consequente re dução do ferro. Acima desta região no perfil de drenagem mais lenta e concentração de nódulos lateríticos e gibbsíticos, è caracterizada por uma porosidade mais elevada permitindo melhor drenagem. Neste caso,o teor de gibbsita tende a aumentar nestas regiões, (Tabela 16), formada por dissilicatização da cau linita. 


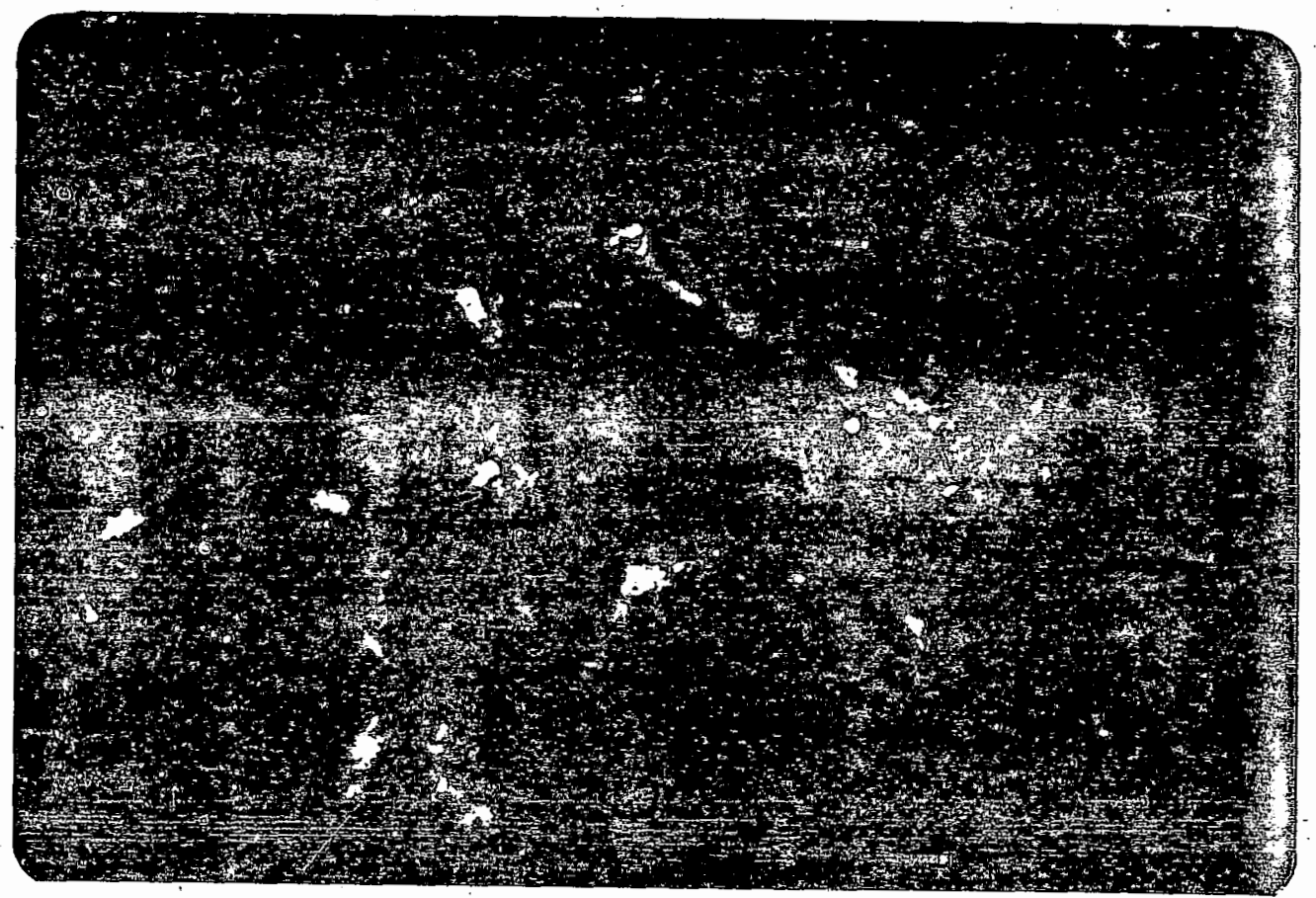

Figura 40,- Perfil PC-2. Horizonte Bw2 (nicois X). Presença de silans preenchendo o vazio. As pontuações brilhantes na matriz do solo são de cristais de gibbsita. 
A medida que se dirige para os perfis com maio res características latossólicas (perfis PC-3 e PC-4) a estru tura tende a individualizar-se em microagregados (Figura 35).

\subsection{Características de pedogênese.}

Neste capítulo há uma tentativa de reunião glo bal de todas as informações colhidas nos tópicos anteriores pa ra um melhor entendimento das áreas estudadas, assim como, da pedogênese dos solos.

Os estudos pedológicos foram desenvolvidos em duas sequências de solos, assinaladas como área I e área II. Devido ao fato destas duas áreas apresentarem um histórico geo morfológico semelhantes, a maioria das interpretações referentes a este aspecto, foram feitas em conjunto. A região de estudo tem como característica principal um relevo bastante movimentado, ondulado, chegando a forte ondulado. Particularmente, nas áreas de estudo, onde ocorrem morrotes, associados e de atitudes diferenciadas, foram escolhidas áreas menos movimentada. A Figura 4 ilustra uma paisagem típica da região estudada, assim como, as posições dos principais perfis anali sados.

De acordo com o reconhecimento das rochas do maciço alcalino de Poços de Caldas, os solos das áreas I e II, foram desenvolvidos, respectivamente, de material resultante da alteração de tinguaitos e fonolitos com lentes de bostolitos e de lavas fenolíticas e foiaitos com lentes de anfiboli tos. Devido à semelhança na composição química destas rochas (Tabela 2), não foram observadas variações significantes na composição mineralógica dos solos entre estas duas áreas. 
Nesta região é bastante comum a ocorrência de material laterítico associado com bauxito, em forma de linha de pedra ou mesmo de cascalheira. A camada lateritica pode ocorrer na superfície, ou a profundidades variáveis, em forma contínua ou não, sendo mais espessa nas quebras do relevo ( $F \underline{i}$ gura 6).

$\mathrm{Na}$ formação destas camadas lateríticas, houve contribuição externa em relação ao ferro, principalmente de superfícies mais elevadas existentes na região, podendo ser constatado pelos teores de óxidos de ferro dos horizontes A e(B) do PC-5. Esta camada mais resistente ao processo erosi vo, teve uma ação significativa no modelado da paisagem atual. Nestas condições, a camada laterítica exposta na área II (Fi gura 6) pode ser remanescente de uma antiga superfície e, nes te caso, parte do perfil PC-5 (horizontes A e B) seria considerado como um solo exumado. Tais resultados estão de acordo com as observações de CHRISTOFOLETTI (1970), que considera co mo antigo o recobrimento concrecionário, não apresentando gênese atual, devido ser encontrado em várias partes soterrado, por camadas coluviais, sem que o paleopavimento perca continuidade entre a parte que se estende pela superfície e a parte soterrada. A gênese e a exposição dessas concreções, são evidência de variação paleoclimática.

Na região do maciço alcalino de Poços de Caldas, principalmente, nas áreas I e II, torna-se evidente à atuação de paleoprocessos no desenvolvimento das superfícies e dos solos, tendo em vista a presença de solos enterradosnes tas duas áreas. Os processos responsáveis pelo desenvolvimen to dos solos e modelagem das superfícies nas duas áreas foram semelhantes e, pelas evidências paleoclimáticas e a preserva ção de paleossolos em alguns locais da regiçao do maciço alca lino de Poços de caldas, sugerem uma evolução policíclica pa- 
ra estes solos, segundo os conceitos de BUTLER (1959); OLLIVIER (1959) e DE VILLIERS (1965).

Os solos que ocorrem nestas duas áreas, são caracterizados, principalmente, pela coloração brunada, nos ma tizes 5YR, 7,5YR e 10YR, estruturada em forma de bloco subangular de grau moderado bastante evidente, e espessura variável, dependendo da posição de ocorrência no relevo. Nas super fícies elevadas e instáveis, mais sujeitas a erosão, são encontrados os perfis menos profundos, representados pelos PC-1, PC-2 na sequência I e PC-5 e PC-8 na sequência II (Figuras 5 e 6), com espessura do solo variando de 0,90 a 1,20 m. Nas superfícies mais estáveis e planas, estão situados os perfis PC-3 e PC-4 na sequência I e PC-6 e PC-7 na sequência II, mais profundos, com espessura superior a $1,50 \mathrm{~m}$. A sequência de ho rizontes é $A,(B), C ; A, B, C$ ou $A, B, A b, B b$ e C. A designação do horizonte (B) foi preliminar e apenas do ponto de vista morfológico.

Tentando reconstruir a história da região estú dada, a sequência II, pode ser tomada como exemplo. No pedimento inferior da superfície desta área, ocorre o PC-7, perfil profundo, com estrutura em bloco subangular pequeno a gran de de grau moderado a forte até os $150 \mathrm{~cm}$ de profundidade. Abaixo,' desta profundidade, ocorre fragmento de lateritas associado a bauxitos e a seguir um horizonte com características de A. Por outro lado, o perfil PC-8, localizado na posição mais elevada desta sequência, também apresenta a mesma se quência de horizontes, tendo inclusive o horizonte enterrado, e, o mesmo tipo de esțrutura, encontrado no PC-7 (Figura 8).

A confirmação da existência da paleossolos nestas duas posições, pode ser feita de diversas maneiras, como foi visto durante a exposição dos demais capítulos. Entre- 
tanto, os estudos feitos a respeito do fracionamdo do húmus parecem ser uma técnica mais adequada para um caso como este. Fọi constatado que os horizontes B são ricos em ácidos fúlvicos e humina, enquanto que os horizontes A são ricos nas frações alcalino-solúveis e humina. Nos horizontes enterrados, no caso dos perfis PC-4 e PC-7, predomina as frações alcalino-solúveis. Tais resultados excluem a possibilidade de trans locação de hūmus dos horizontes superficiais e posterior concentração nos horizontes mais inferiores.

Neste caso, e levando-se em consideração, que - PC-8, ocupa a posição mais alta da área II e o PC-7 a mais baixa, é de se supor que no passado todo este vale deveria ter sido coberto por material semelhante a estes dois perfis extremos.

A coloração vermelha nos horizontes $\mathrm{Bb}$ (perfis PC-4, PC-7 e PC-8) no matiz 2,5YR, é típica de solos ondepredomina a hematita, o que foi comprovado pela difração, de raios-X e tambēm, através dos baixos valores de Al-substituição nestes horizontes.

Morfologicamente, a estrutura dos horizontes $B$ que se desenvolveu neste período é tipicamente em forma de blo cos subangulares de grau fraco a moderado, praticamente preservada ao longo dos tempos.

Os dados granulométricos não evidenciaram iluviação de argila, assim como, os exames micromorfológicos não constataram cutans iluviais suficientes para caracterizar um horizonte B textural ou argílico. Consequentemente, os solos estudados, alēm de serem argilosos, não desenvolveram horizon tes argílicos, apesar da maioria dos perfis apresentarem uma estrutura no B, semelhante a da Terra Roxa Estruturada. O desenvolvimento desta estrutura pode estar relacionada à pre- 
sença de material amorfo, altamente hidratado, com capacidade de retrair-se rapidamente, após a exposição.

Por outro lado, os horizontes B incipientes ou câm bicos indicados preliminarmente no exame morfológico de alalguns perfis, não possuem evidências mineralógicas para sua classificação, principalmente, no que se refere as percentagens de minerais primários. A quantidade de mica e feldspato, no horizonte $B$ não é suficiente para permitir a definição de B incipiente ou câmbico.

De acordo com estudos geológicos da região (EL - LERT, 1959) o desenvolvimento dos solos deve ter-se iniciado no período Cretáceo, possivelmente em ambiente quente e úmido. A comprovação deste fato é obtido através dos estudos micromorfológicos que demonstram a formação de gibbsita I por intemperismo direto do feldspato. Nesse ambiente de intensa lixiviação, a atividade da sílica e das bases é baixa, não permitindo a formação de minais $2: 1$; como visto por KITTRICK (1969). A concentração de Al amorfo ou mesmo de gibbsita ou associação de amios nos vazios e a cavidades do solo leva a formação de nódulos (Figura 37) e mesmo cristalaria (Figuras 34 e 37). Além do mais, a composição mine ralógica dos horizontes enterrados é caracterizada também pela predominância de caulinita e gibbsita, minerais índices de regime quente e úmido (JACKSON, 1964).

Neste mesmo período, houve a formação de cauli nita, juntamente com haloisita desidratada, também por proces sos de intemperismo do feldspato ou mesmo ressilicatização de gibbsita. Tal processo é possível de ocorrer, uma vez que é bastante comum a ocorrência de silans nas secções delgadas dos solos. Como a atividade da sílica é controlada pela sílica do solo (sílica amorfa) e não pelo quartzo (LINDSAY, 1982) a combinação da gibbsita com a sílica amorfa é bastante provável. Em ambientes específicos de gênese existentes na área, 
tais como, às proximidades do material de partida e redução da drenagem do solo, ou então, localização de encostas, onde a.lixiviação é menos intensa, a atividade do ácido silícico é elevada, assim como, a relação Si/Al. Associada a estas características e presença de $\mathrm{K}^{+}$fornecido pelos feldspatos po de levar à formação de micas (LINDSAY, 1982). Como as condições existentes tanto na área I como na área II, estão mais relacionadas a grande lixiviação, a formação de micas épequena, como vista nos dados mineralógicos.

A drenagem pobre ou impedida comprovada pela presença de cores acromáticas no horizonte $C$ dos perfis PC-2 e PC-5, evidencia que é perfeitamente possível ocorrer condições favoráveis para formação de micas, nestes solos.

A formação de vermiculita com hidroxila interlamelar nesse meio muito rico em gibbsita e ocorrência moderada de mica, se processa através da perda da estabilidade da mica e introdução, posterior, de uma camada octaédrica de hidroxilas entre as unidades cristalinas de mica, formando a vermiculita cloritizada ou vermiculita com hidroxila interla melar. A coexistência das micas com a gibbsita, num mesmo am biente (associação pouco provável segundo KITTRICK (1969), pode ser explicada pelos dados de PEDRO (1966).

A presença de feldspatos, mesmo de tamanho da fração areia, nestes solos é explicado pelo revestimento ou capeamento feito pelos óxidos de ferxo (Figura 32) isolando-o do intemperismo.

A ferruginização do plasma também ocorreu concomitantemente com a formação do solo, primeiramente difundido em toda a estrutura, com concentrações mais avermelhadas e depois localizadas ao redor do esqueleto e do vazio. A concentração do ferro, da mesma maneira que a do alumínio, deu 
origem aos nódulos de ferro, ocorrendo principalmente nas encostas íngrimes da área, região de segregação do ferro para formação de lateritas. Neste caso, a mobilização do ferro $\left(\mathrm{Fe}^{2+}\right)$ se deu também em região de drenagem impedida ou pobre, já comprovado na morfologia e, depois por migração lateral se concentra, oxida e recristaliza formando laterita.

A matriz do solo é constituída essencialmente, por caulinita e gibbsita. A associação da caulinita com microcristais de gibbsita, altamente anisotrópico, resultou na formação de uma estrutura plásmica sépica e não isótica como na máioria dos oxissolos.

Durante a formação dos solos, alterações climá ticas ocorreram na região (CHRISTỌFOLETI, 1970), possivelmen te entre o Pliocenio e Pleistoceno (Bushee, 1971, citado por MOLITERNO et alii, 1983), houve um recobrimento total da paisagem original com material pré-intemperizado em mistura com rocha. A natureza deste novo material é bastante semelhante ao do anterior. Os resultados físicos, químicos e mineralógicos ilustram uma pequena quebra nos dados em profundidade; quebra esta, coincidente com o início do paleossolo. Entretan to, existe certa semelhanta entre os materiais, principalmente no que se refere a textura argilosa ou muito argilosa, na natureza da fração argilia e nas feições micromorfológicas.

Além deste fato, há necessidade de levar- se, tambēm em consideração, a preservação dos horizontes $\mathrm{Ab}$ e $\mathrm{Bb}$ durante as alterações climáticas. Tudo leva a concluir que os processos de erosão e deposição não ocorreram com grande in tensidade, caso contrário, não haveria o testemunho deixado pelos perfis estudados. Com o material do recobrimento é bas tante semelhante ao original, conclui-se também, que em termos de escala, o recobrimento foi regional e consequentemente de pequena intensidade. 
Na sequência de solos da área I (Figura 5) o recobrimento contribuiu com material para o desenvolvimento dos horizontes A e B dos perfis PC-1 e PC-2, situados na parte alta, enquanto que, o horizonte $C$ destes perfis teve sua formação, provavelmente, devido a alteração da rocha in situ. A mesma interpretação pode ser atribuída ao desenvolvimento do perfil PC-5, localizado na encosta da área II (Figura.6).

Após o recobrimento desenvolveu-se a pedogênese atual, com novo modelado da paisagem através de processos erosivios originando as superfícies atuais. Neste processo erosivo houve o aparecimento parcial da antiga superfície, evi denciada pela cascalheira do PC-5. A ação da camada laterítí ca e principalmente das cascalheiras teve fundamental importância no modelado atual da paisagem. Os processos pedogenéticos continuaram a agir neste novo material de. recobrimento e as transformações afetaram praticamente quase todas as propriedades estudadas.

O principal processo pedogenētico ainda atuante, continua sendo a lixiviação intensa, conduzindo a formação de material caulinítico, amorfo e gibbsitico. A frequente passagem da solução do solo através das fissutas e canais, tende a carregar parte da sílica das estruturas cristalinas, principalmente dạ caulinita, por ser esta o componenente mais abundante do plasma, dando como resultado a formação de gibsans (Figuras 33, 34 e 37). A sílica removida pôde formar sí lans, como visto anteriormente, inclusive concentrando-se para formar quartzo secundário. Do mesmo moủo, ocorreu a formação de sesquans e nóduløs de ferro, alumínio e ferri-alumínio, estes do tamanho ou maior que as frações areia e silte.

Durante esta pedogênese, a estrutura plásmica continua sendo ainda sépica, porém evolui da latissépica, nos 
horizontes mais inferiores, para argilasépica, nos horizontes superiores. Apesar de ser material bastante intemperizado 0 plasma não atingiu ainda a forma isotópica, tipico dos oxissolos. Tal fato se deve ainda à ocorrência de microagregados de gibbsita bastante anisotrópico. Apesar destes perfis serem também argilosos ou muito argilosos, não há evidência de translocação de argila. As secções delgadas mostraram apenas - concentrações plasmáticas isoladas, com alguns argilans, porēm a maioria deles sendo de segregação e não de iluviação.

De acordo com os dados mineralógicos, grande parte da mineralogia da fração argila e mesmo das demais frações é devido ao intemperismo do feldspato. As principais se quências de intemperismo, a partir deste mineral seriam:

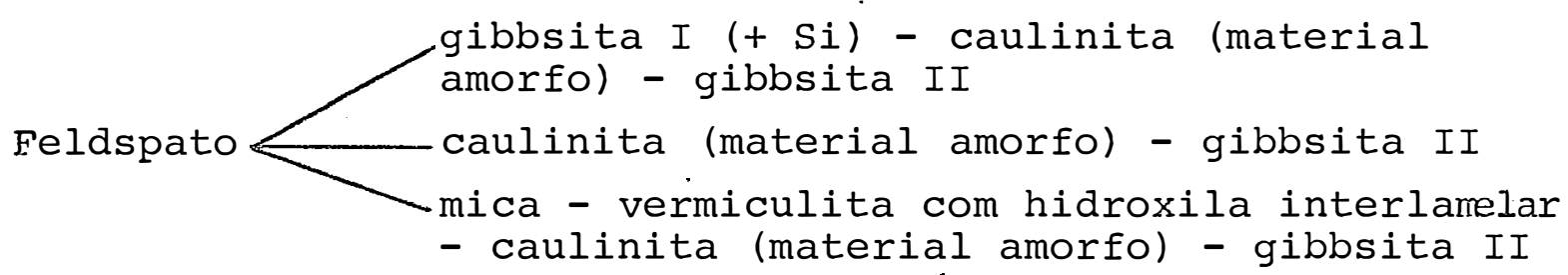

A matiz dos horizontes B de todos os solos estudados varia de 5YR 4-6/6-7 a lOYR 4-8/4, porém com predomí nância na matiz intermediária 7,5YR 4-5/2-6, dando as cores brunadas. A predominância nesta matiz é de goethita, como foi visto na difração de raios-X.

A formação de hematita e goethita pode ser influenciada pela presença no meio do ion $\mathrm{Al}^{3+}$. De maneira geral, pequena quantidade de $\mathrm{Al}^{3+}$ favorece a formação de hematita. Como foi visto, a hematita concentra-se principalmen te nos horizontes $\mathrm{Bb}$ dos solos, enquanto que, a grande quanti dade de $\mathrm{Al}^{3+}$, favoreceram a formação de goethita no recobrimen to. Além deste fato, nos solos atuais, a substituição do $\mathrm{Al}^{3+}$ nas estruturas cristalinas dos óxidos de ferro é grande, que 
aliado aos alargamentos nos picos de difração de raios-X, definem goethita mal cristalizada. Este alargamento dos picos de goethita tem sido interpretada por SCHWERTMANN (1983) como decréscimo na cristalinidade deste material com Al - substitú ição.

De acordo com estes resultados, é de supor que - a transformação de hematita em goethita seja devido a uma maior ação do intemperismo sobre o recobrimento atual. Esta transformação foi acelerada pela presença, em solução, de con centrações elevadas de $\mathrm{Al}^{3+}$.

Os solos localizados tanto na sequência I como na II, desenvolvem horizontes $B$ de grau diferenciado de es trutura, sendo em blocos subangulares ou com aspecto maciça. A estrutura com aspecto maciça sempre ocupa a posição no perfil abaixo da estrutura em blocos. Além do recobrimento morfológico a estrutura com aspecto maciça (composta de microagregados granular) é observada pelas secções delgadas. O per fil PC-7 é o que apresenta maior espessura de estrutura em blocos, vindo a seguir a estrutura com aspecto maciça. Como este perfil localiza-se na parte inferior do pedimento é possível que este maior desenvolvimento de estrutura possa estar associado ao fluxo lateral de água mais intenso (i.HONIZ e BUOL, 1982). E devido a este tipo de estrutura mais desenvolvida, as . sociada a cor, que alguns destes solos receberam a designação de Terra Bruna Estruturada (EMBRAPA, 1980a, b e 1982). A formação e o grau de desenvolvimento deste tipo de estrutura devem estar relacionados, além da posição que os solos ocupain na paisagem, a ação de material amorfos, altamente hidratável, que têm a propriedade de retrair-se rapidamente quando o solo é exposto. Os demais perfis, também possuem este tipo de estrutura, porém em grau menos acentuado. 
O maior desenvolvimento da estrutura na parte mais elevada e instável da área I (PC-1 e PC-2) e da área II (PC-8) deve-se à presença de teores mais elevados de material amorfos, enquanto que, na parte inferior do pedimento da área I (PC-4) e da área II (PC-7), esse maior desenvolvimento teve também a colaboração do fluxo lateral de água, na formação deste tipo de estrutura. •

Levando-se em consideração as posições dos per fis dos solos na paisagem é possível separá-los de acordo com o grau de intemperismo, no caso, utilizando-se os teores médios da gibbsita como mineral índice. Os perfis PC-3 e PC-4 são mais intemperizados com teores médios de $26 \%$ de gibbsita; seguidos dos perfis PC-6 e PC-7, em estágio intermediário de intemperismo, com teores médios de 13 e $16 \%$ de gibbsita, respectivamente, e finalmente os demais perfis em estágio de intemperismo menos evoluídos, com teores médios de 7 a $10 \%$ de gibbsita. A posição de ocorrência dos perfis PC-3, PC-4 e PC-7, na paisagem é de superfície mais estáveis e, portanto, com maior facilidade de lixiviação, por isso, mais intemperi zados. Por outro lado, os demais perfis ao ocuparem superfícies mais instáveis e portanto menos lixiviados, são menos alterados.

Os teores de material amorfos (alofanas) mais elevados nos perfis PC-1 e PC-2, na superfície mais alta $E$ instável da área $I$, se deve a um menor grau de intemperiza.̧ão destes solos, em relação aos demais, porque a medida que o intemperismo evolui o teor de material amorfos diminue.

Os dados analíticos de todos os solos estudados e principalmente dos perfis mais evoluídos, definem a pre sença de horizonte óxico ou B latossôlico, tanto na posição de estrutura moderada ou fraca bloco subangular. 


\subsection{Classificação dos solos}

Os solos estudados na área do maciço alcalino de Poços de Caldas foram classificados segundo o sistema brasileiro de classificação de solos proposto por BENNEMA (1966) com modificações introduzidas pelo Serviço Nacional de Lèvantamento e Conservação de solos - SNLCS/EMBRAPA e pelo sistema americano - Soil Taxonomy (Estados Unidos, 1975).

Estes solos apresentam características morfológicas semelhantes às Terras Brunas Estruturadas e aos Latossolos Brunos, identificados no sul do Brasil (EMBRAPA, 1980a e b). Os solos identificados como Terras Brunas Estrutura-das no sul do Brasil caracterizam-se pela presença de horizonte B textural, cerosidade moderada a forte, baixo gradiente textural, teores elevados de óxidos de ferro ( $>13 \%$ de $\mathrm{Fe}_{2} \mathrm{O}_{3}$ ) e alumínio, e sequência de horizontes A, Bt e C. Apresentam uma certa semelhança com as Terras Roxas Estruturadas, pelo aspecto da estruturação, diferindo destas: a) pela coloração brunada do horizonte subsuperficial, compreendidas nos matizes 5YR, 7,5YR e 10YR; b) menor espessura do solum; menor grau de desenvolvimento de estrutura e da cerosidade. São aliás, muito argilosas, e com teores elevados de silte. Os Latossolos brunos são caracterizados principalmente pela presença de cores brunadas e teores elevados de óxidos de fer ro ( $>20 \%$ de $\mathrm{Fe}_{2} \mathrm{O}_{3}$ ). As cores brunadas compreendidas nos mati zes 7,5YR e 10YR têm sido incluídas na cor amarela na região Amazônica.

Os solos quie ocorrem nas duas áreas de estudo, amostrados como Terras Brunas Estruturadas, perfis PC-2 e PC-7, diferem destas, quanto ao tipo de horizonte $B$, ausência de cerosidade, menores teores de óxidos de ferro $(<13 \%$ de $\mathrm{Fe}_{2} \mathrm{O}_{3}$ ) e sequência de horizontes $\mathrm{A}$, BW e C. Contudo, apresen 
tam coloração brunada e aspecto de estrutura semelhante as Terras Brunas Estruturadas. . Os perfis PC-3 e PC-4 descri tos como Latossolos Brunos, diferem destes pelos teores de óxi dos de ferro mais baixos (<10\% de $\mathrm{Fe}_{2} \mathrm{O}_{3}$ ), mas, apresentam coloração brunada.

Os horizontes B incipiente ou câmbicos indica dos nas descrições morfológicas dos perfis PC-1, PC-5 e PC-6, de acordo com os resultados analíticos, principalmente mineralógicos, não possuem evidências para confirmação deste tipo de horizonte. Alēm deste fato, não foi constatado, também a ocorrência de horizonte B textural ou argílico, devido a au- sência de argilans de iluviação, assim como, de incremento de argila em profundidade. Pelos dados analíticos pode-se definir para estes solos a presença de horizonte B latossólico ou óxico.

As características referentes a cor, espessura e teor de carbono dos horizontes superficiais dos solos es tudados são pertinentes à presença de horizonte diagnóstico superficial - epipedon ócrico ou A moderado para o perfil PC-5 e epipedon úmbrico ou A proeminente para os demais perfis.

Todos os perfis de solos estudados nas duas āreas apresentam as seguintes características:

a) espessura maior que $30 \mathrm{~cm}$;

b) baixo gradiente textural, relação B/A em torno de 1 ;

c) ausência de argilans de iluviação;

d) percentagens de minerais primārios mais resistentes ao intemperismo, ou mica, na fra-

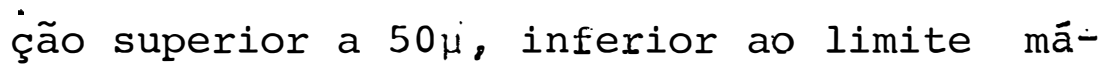
ximo permitido ( $<4 \%$ e $<6 \%$, respectivamente) para o horizonte $B$ latossólico ou óxico; 
e) ausência de fragmentos do material de parti da na massa do solo;

f) capacidade de troca cationica inferior a $16 \mathrm{me} / 100 \mathrm{~g}$ ou inferior a $13 \mathrm{me} / 100 \mathrm{~g}$ de argila após correção para carbono;

g) retenção catiônica inferior a $10 \mathrm{me} / 100 \mathrm{~g}$ de argi.la;

h) relação silte/argila inferior a 0,6;

i) relação Ki inferior a 2,0 e textura muito argilosa.

De acordo com tais dados, os perfis foram incluídos na categoria de solos com horizonte B latossólico ou óxico, com exceção do $\mathrm{PC}-5$. Tal perfil (PC-5) apresenta horizonte B com espessura inferior a $50 \mathrm{~cm}$. Sendo assim, e de acordo com este critério do sistema brasileiro de classificação, ele foi incluído na classe de horizonte (B) incipiente. Por outro lado, se considerarmos os critérios da Soil Ta xonomy, O PC-5 será incluído como horizonte óxico.

Relacionando-se as características dos perfis PC-2 e PC-7 com as Terras Brunas Estruturadas, observa-se uma semelhança em relação à cor, grau de desenvolvimento da estrú tura, classe de textura, gradiente textural e dessaturação do solo. Estas características, contudo, não são suficientes pa ra integrá-los na categoria das Terras Brunas Estruturadas, pela não constatação de cerosidade ou seja, argilans de iluviação observáveis nas lâminas, que caracterizaria a presen ça de horizonte $B$ textural ou argílico, horizonte típico desses solos.

Levando-se em consideração outras propriedades dos solos, além das consideradas comó diagnósticas, como o re gime de umidade údico e isotérmico de temperatura, predominan 
tes na região, assim como, o tipo de epipedon, a mineralogia, tipo de estrutura e presença de nódulos gibbsíticos para a Soil Taxonomy e, junção de cores com teores totais de óxidos de ferro para a classificação brasileira, os perfis podem ser tentativamente incluídos nas classes, apresentadas na Tabela 17.

No sistema brasileiro de classificação de solos, os Latossolos são classificados com base no teor total de óxidos de ferro extraído pelo ataque sulfúrico, contudo, este critério não deveria ser utilizado como característica dia gnóstico principal, tendo em vista que, o teor de. ferro no solo não explica os processos pedogenéticos de formação do solo, assim como, a sua mineralogia.

Diversos autores estudando relações entre óxidos de ferro e a cor do solo (WEAVER, 1974; DAVEY et alii, 1975; RESENDE, 1976; RODRIGUES, 1977; BIGHAN et alii, 1978b; VOLKOFF, 1978; VOLKOFF e RIBEIRO, 1979; SHCWERTMANN et alii, 1982 e KAMPF e SCHWERTMANN, 1983) constataram que a cor do so lo é determinada pelo tipo de óxido de ferro e principalmente, pela concentração de hemaitita presente, de maneira que, as cores brunadas e amarelas estão relacionadas a presença de goethita, enquanto que, as cores vermelhas refere-se à presen ça de hematita. Tal fato, sugere que não se deve utilizar os teores de óxidos de ferro total, como critério ünico na distinção de classes de solos através da cor, tendo em vista que, solos de cores amarelas podem apresentar teores bastantes ele vados de óxidos de ferro, o que nem sempre ocorre com os "solos de cores vermelhas.

De acordo com os teores de ferro total extraído pelo ataque sulfúrico inferior a 10\%, mas, com a coloração brunada nos matizes $10 \mathrm{YR}$ e $7,5 \mathrm{YR}$, os perfis $\mathrm{PC}-2$ e $\mathrm{PC}-7$ fo 


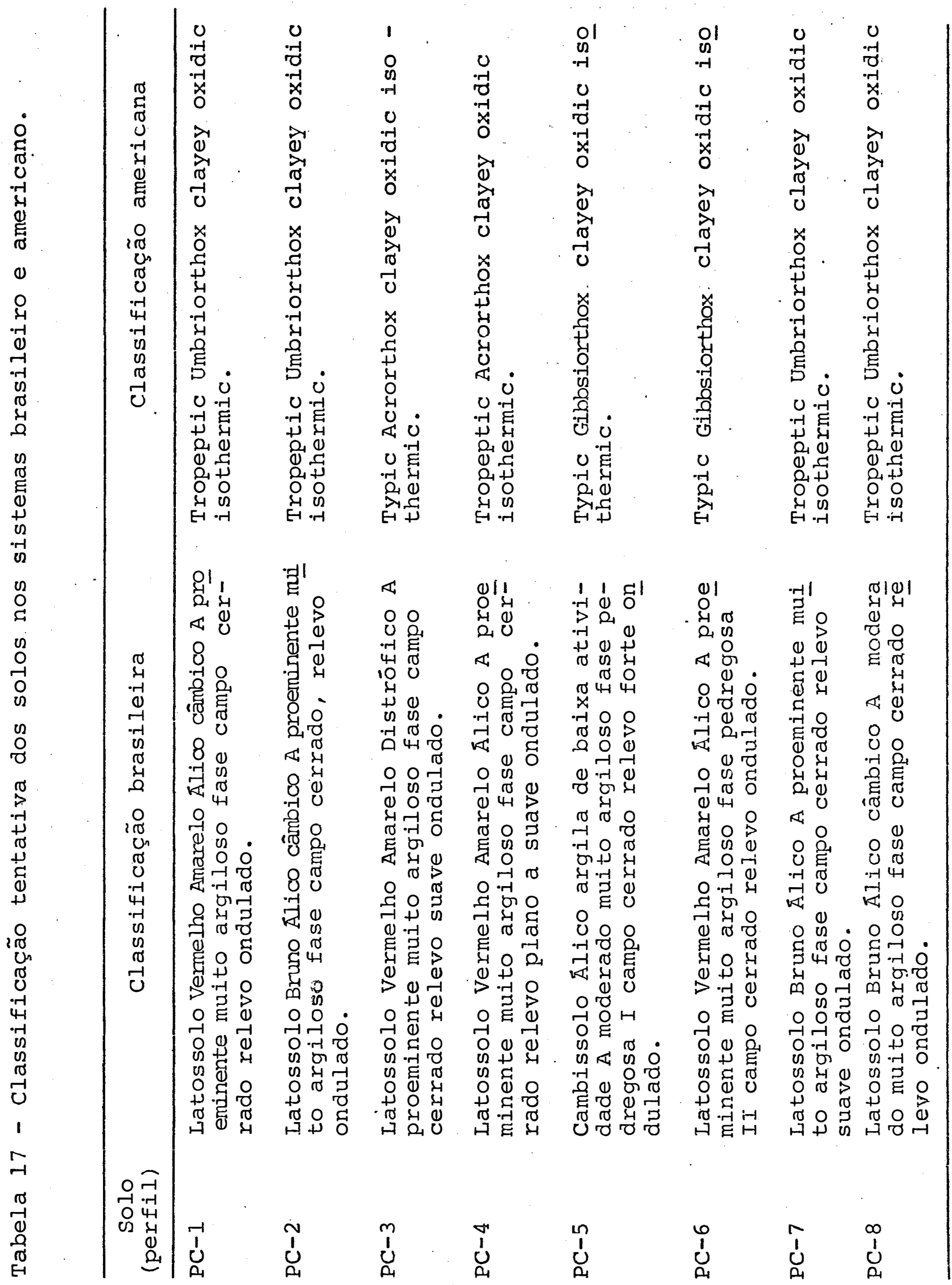


ram incluídos na classe dos Latossolos Brunos, apesar de apre sentarem teores de óxidos de ferro (Tabela 1) inferiores aos dos Latossolos Brunos ( $>20 \%$ de $\mathrm{Fe}_{2} \mathrm{O}_{3}$ ) encontrados no sul do Brasil (BRASIL, 1973 e EMBRAPA, 1980a e b). Os perfis PC-1, PC-3, OC-4 e PC-6, também com teores de óxidos de ferro total inferior a 10\%, mas, com coloração variando de bruno avermelha do no matiz 5YR a vermelho escuro no matiz 2,5YR, foram enquadrados nos Latossolos Vermelhos Amarelos e o perfil PC-5 nos Cambissolos por não atingir a espessura mímima para horizonte B latossólico, apesar de ter horizonte óxico. Os solos correspondentes aos perfis PC-1, PC-2 e PC-8 foram considerados como intermediários para cambissolo pela pequena espessura do solo e pelas quantidades de feldspatos e mica encontradas nestes solos.

Na Soil Taxonomy os solos foram enquadrados na subordem Orthox, nos grandes grupos Acrosthox (perfis PC-3 e PC-4), Umbriorthox (perfis.PC-1, PC-2 e PC-7) e Gibbsiorthox (perfis PC-5 e PC-6). Além do subgrupo Typic, foi utiliza do o subgrupo Tropeptic para caracterizar solos oxidicos com estrutura mais desenvolvida. Por similaridade, com a Soil Taxonomy, já que o sistema brasileiro de classificação de solos tem adotado grande parte da Soil Taxonomy, seria de gran de utilidade a criação de um subgrupo dentro dos Latossolos que incluisse solos semelhantes as Terras Brunas Estruturadas. 


\section{CONCLUSÕES}

Os resultadós apresentados e discutidos deste trabalho permitem estabelecer as seguintes conclusões:

a - As diferenças relacionadas à cor destes solos, estão associadas aos tipos de óxidos de ferro; as cores brunadas referem-se a presença de goethita e as vermelhas a hematita. A presença de goethita está relacionada ao recobrimento mais recente, enquanto que, a presença da hematita relaciona-se aos solos enterrados;

b - o tipo de estrutura em forma de bloco subangular de grau moderado, bastante evidente, mas, pouco variável na maioria dos perfis, reflete a influência de material amorfos altamente hidratável, tanto na par te alta e instável da paisagem, como na parte baixa, onde o fluxo lateral de água concorre para a for mação deste tipo de estrutura:

c. - Os valores de superfície (64 a $187 \mathrm{~m}^{2} / \mathrm{g}$ ) para solos com mineralogia $1: 1$, refletem a influência da material amorfos, mica e matéria orgânica no complexo coloidal destes solos; 
d - A pequena variação no teor de água sob as tensões de 1,0 a 15 atmosferas é o reflexo da textura muito argilosa, associada a mineralogia de baixa ativida de, restringindo a água disponível a baixas tensões;

e - Os teores elevados de matéria orgânica nos horizon tes subsuperficiais dos perfis PC-4, PC-7 e PC-8, cor respondem a horizontes $A$ de solos enterrados e não a horizontes $B$ de acumulação iluvial de matéria orgânica;

f - A utilização dos componentes da matéria orgânica, resultantes do fracionamento do húmus, como compostos indices, na identificação de solos enterrados é bastante promissora;

e - Todos os perfis estudados são dessaturados, álicos e distróficos;

h - As curvas de titulação potenciométrica para determi nação do PCZ destes solos, foram similares às de óxidos de ferro, de caulinita e de solos tropicais, indicando que o comportamento eletroquímico destes solos pode ser analisado pelo sistema de cargas variáveis;

i - Os óxidos de ferro presentes nestes solos estão representados em sua maior parte pela goethita-Al-subs tituída. A transformação da hematita em goethita, num meio rico en alumínio, ocorreu a partir do solo atual para o paleossolo; 
j - A gibbsita encontrada nestes solos demanda duas origens distintas: a gibbsita primária I formada pela alteração direta de feldspatos, apresentando-se no tamanho das frações areia e silte; e a gibbsita secundária II formada pela dessilicatização da caulinita através de uma fase intermediária de materiais e consequente recristalização à gibbsita;

k - A caulinita dominante na fração argila foi formada pela alteração direta do deldspato, ressilicatização da gibbsita primária I e da alteração da mica;

1 - A persistência nos solos da vermiculita com hidroxila interlamelar é decorrente do processo de alumi nação das intercamadas dos minerais de argila 2:1, que reduz a sua capacidade de troca e.proporciona lhe uma maior estabilidade;

m - A mica encontrada nestes solos é uma mica secundária, originada pela àlteração de feldspatos na presença de $\mathrm{K}^{+}$, uma vez que as rochas alcalinas de Poços de Caldas não possuem mica em sua constituição;

n - A matriz do solo é constituída essencialmente por caulinita e gibbsita. A associação da caulinita com microcristais de gibbsita, altamente anisotrópico, resultou na formação de uma estrutura plásmica sépica;

- - A presença de feldspato, mesmo do tamanho da fração areia, nestes solos, é devido ao revestimento pelos óxidos de ferro, isolando-o do intemperismo; 
p - Todos os perfis estudados possuem características de horizonte B latossólico, com exceção do perfil PC-5 que apresenta horizonte $\mathrm{B}$ incipiente;

$\mathrm{q}$ - Os teores de óxidos de ferro total ( $\left.\leq 9 \% \mathrm{Fe}_{2} \mathrm{O}_{3}-\mathrm{H}_{2} \mathrm{SO}_{4}\right)$ permitem enquadrar estes solos na classe dos Latossolos Brunos e Vermelhos Amarelos. A única distinção entre eles seria a estruturação em blocos subangulares de grau moderado mais evidente, nos perfis PC-1, PC-2, PC-4, PC-7 e PC-8. Entretanto, tal critério não é considerado como distintivo entre clas ses de solos no sistema brasileiro de classificação;

$r$ - Os solos correspondentes aos perfis PC-2 e PC-7,iden tificados por suas características morfológicas como Terras Brunas Estruturadas, foram classificados como Latossolos, devido a ausência do horizonte B te stural;

s - A criação de um subgrupo dentro dos Latossolos que incluissem os solos semelhantes as Terras Brunas Es truturadas, serviria para grupar justamente os solos com características oxídicas, porém, com estrutura mais desenvolvida. 
LITERATURA C CITADA

ACRA, M.N. e S.W. WEEP, 1966. Soil aggregation and porosity in relation to contents of free iron oxides and clay. Soil Sci. Baltimore 101: 164-170.

ALEXANDER, E.B., 1974. Extractable iron in relation to soil age an terraces along the Truckee River, Nevada. Soil Sci. Soc. Amer. Proc. Madison, 38: 121-124.

ALEXANDER, L.T. e J.G. CADY, 1962. Genesis and hardening of laterite in soils. Washington. United States Department of Agriculture. Soil Conservation Service. 90 p.

ALEXIADES, A.C. e M.L. JACKSON, 1966. Quantitative clay mineralogical analysis of soil and sediments. In: NATIONAL CON FERENCE ON CLAYS MINERAKS, 149. Canadá, 1965. Proceedings. New York. Pergamon Press p. 35-52.

ALOISI, R.R.; G. RANZANI; J.L.I. DEMATTE e C.C. CERRI, 1976. Mineralogia da fração argila de alguns solos do município de Jaboticabal, SP. In: Congresso Brasileiro de Ciência do Solo, 159, Campinas, SP. 1975. Anais da Soc. Bras. ci. Solo, Campinas, p. 457-460. 
ALONSO, M.T.A., 1977. Vegetação. 'In: FUNDAÇÃO INSTITUTO BRA SILEIRO DE GEOGRAFIA E ESTATISTICA. Geografia do Brasil Região Sudeste. Rio de Janeiro. V. 3. Região Sudeste, p. 91-118.

AMEDEE, G. e M. PEECH, 1976. The significance of $\mathrm{KCl}$-extractable $A l$ (III) as an index to lime requirements of soils of the humid tropics. Soil Sci. Baltimore, 121: 227-233.

ANDRADE, S.S. de; A.C. MONIZ; H.G. dos SANTOS e H. da C. ALMEIDA, 1976. Sequência de evolução de solos bem drenados originados de rochas eruptivas bāsicas da região fisiogrāfica de Campo Grande, MT. In: Congresso Brasileiro de Ciên cia do Solo, 15. Campinas, SP, 1975. Anais, Soc. Bras. Ci. Solo, Campinas, p. 518-523.

ANTONELLO, L.L., 1982. Gênese de uma sequência de solos de rochas alcalinas do maciço alcalino de Itatiaia, RJ: mineralogia, geoquímica e micromorfologia. Tese de Doutorado. Universidade Federal do Rio de Janeiro. Rio de Janeiro, $262 \mathrm{p}$.

ASHAYE, T.J., 1969. Sésquioxide status and particle size distribution in twelve Nigerian soils derived from sandstone. African soils: 14: 85-86.

AUBERT, G., 1954. Les sols lateritiques. In: International Congress Soil Science, 50 General leture. 7 Aug. 1954. Mimeografado. Apud. MONIZ, A.C. e M.L. JACKSON, 1967. Quantitative mineralogical analysis of brasilian soils derived from basic rocks and slate. Madison. University of Wis consin, 74 p. (Wisconsin Soil Science Report 212). 
AZEVEDO, L.G., 1962. Tipos de vegetação do sul de Minas e Cam pos da Mantiqueira. Anais da Academia Brasileira de Ciências. Rio de Janeiro, 34: 225-243.

BARBOSA, O., 1936. Notas preliminares sobre o planalto de Poços de Caldas e suas possibilidades econômicas. Dep. Nac. Prod. Min., Serv. Fom. Prod. Min., Rio de Janeiro. Avulso 8, $33 \mathrm{p}$.

BENNEMA, J. e M.N. CAMARGO, 1964. Esboço parcial da segunda aproximação de solos brasileiros; subsídios à IV Reunião Técnica de Levantamento de Solos. Rio de Janeiro, Ministério da Agricultura. Divisão de Pedologia e Fertilidade do Solo. $17 \mathrm{p}$.

BENNEMA, J., 1966. Classification of Brazilian soils. Report to the government of Brazil. Food and Agriculture Organization of the United Nations. Rome. $23 \mathrm{p}$.

BATES, T.F., 1960. Rock weathering and clay formation in Ha- waii. Mineralogy Ind. 28:1-6.

BIGHAN, J.M.; D.C. GOLDEN; L.H. BOWEN; S.W. BUOL e S.B. WEED, 1978a. Iron oxide mineralogy of well-drained Ultisols and oxisols. I. Characterization of iron oxides in soil clay by Mössbauer spectroscopy, X-ray diffractometry, and seluted chemical techniques. Soil Sci. Soc. Amer. J. Madison, 42: 817-825.

BIGHAN, J.M.; D.C. GOLDEN; L.H. BOWEN; S.W. BUOL e S.B. WEED, 1978b. Iron oxide mineralogy of well-drained Ultisols and Oxisols. II. Influence on color, surface area and phosphate retention. Soil Sci. Soc. Amer. J. Madison, 42: 825-830. 
BLUME, H.P. e U. SCHWERTMANN, 1969. Genetic evaluation of pro file distribution of aluminum, iron, and manganese oxides. Soil Sci. Soc. Amer. Proc., Madison, 33: 438-444.

BOWDEN, J.W.; A.M. POSNER E J.P. QUIRK, 1980. Adsorption and charging phenomena in variable charge soils. In: THENG,B. K.G. ed. Soils with variable charge. New Zealand Soc. Soil Sci. Palmerston North. Lower Hutt p. 147-165.

BRfSIL. Ministério da Agricultura. Departamento Nacional de Pesquisa Agropecuária. Divisão de Pesquisas Pedológicas, 1973. Levantamento de reconhecimento dos solos do Estado. do Rio Grande do Sul. Recife (Boletim Técnico, 30).

BREWER, R., 1976. Fabric and mineral analysis of soils. John Willey and Sons, New York. $470 \mathrm{p}$.

BREWER, R., 1972. Use of macro and micromorphological data in soil stratigraphy to elucidate surficial geology and. soil genesis. Jour. Geol. Soc. Australia, Melbourne, 19: 331 344 .

BROADBENT, F.E.; R.H. JACKMAN e J. MCNICOLL, 1964. Mineraliza tion of carbon and nitrogen in some New Zealand allophanic soils. Soil Sci. Baltimore, 98: 118-128.

BROWN, G., 1961. The X-ray identification and crystal structure of clays minerals. Mineralogical Society, London. 544 p.

BUOL, S.W. e M.D. FADNESS, 1961. New method of impregnating fragile material for thin sectioning. Soil Sci. Soc. Amer. Proc., Madison, 25: 253-258: 
BUSHEE, J., 1971. Potassium-argon ages of some alcaline rocks. from Southern Brazil. Ph.D. Dissertação. University of California, Bekerley, 145 p. Apud. MOLITERNO, A.M.C.; M. KORITIAKE; M.J.N. de SOUZA e S.K. RODRIGUEZ, 1983. Projeto. Boavista. Instituto de Geociências e Ciências Exatas.UnESP Rंio Claro, 190 p.

BUTTLER, B.E., 1959. Periodic phenomena in landscapes as a basis for soil studies. CSIRO Aust. Soil Publication, 14 . Melbourne. 20 p.

CADY, J.G., 1965. Petrographic microscope techniques. In: BLACK, C.A. ed. Methods of soil analysis, Part I. American Society Agronomy, Madison. p. 617-622.

CARTER, D.L.; M.D. HEILMAN e C.L. GONZALEZ, 1965. Ethylene glicol monoethyl ether for determining surface area of sili cate minerals. Soil Sci. Baltimore 100: 356-360.

CASHEN, G.H., 1959. Electric charges of kaolin. Trans. Faraday Soc. 55: 477-486.

CIHACEK, L.J. A J.M. BREMNER, 1979. A simplified ethylene gly col monoethyl ethef procedure for assessment for soil surfa ce area. Soil Sci. Soc. Amer. J. 43: 821-822.

CRISTOFOLETTI, A., 1970. Análise morfométrica das bacias hidrográficas do planalto de Poços de caldas (MG). Tese de Livre Docência. Faculdade de Filosofia, Ciências e Letras, UNESP, Rio Claro, São Paulo. 215 p. (não publicada).

DABIN, B., 1971. Etude d'une methode de fractionnement des matiēres humiqués dy soil Science du Sol. Paris, 1: 47-63. 
DAVEY, B.G.; J.D. RUSSEL; M.J. WILSON, 1975. Iron oxide acic clay minerals and their relation to colours of red and yellow podzolic soils near Sydney, Australia. "Geoderma, Amsterdam, 14: 125-138.

DECHEN, S.C.F., 1979. Caracterização e mineralogia de solos. desenvolvidos de folhelho e arenito. Tese de Doutoramento. Escola Superior de Agricultura "Luiz de Queiroz"-USP, Pira cicaba, São Paulo. 235 p. (Não publicada).

DEMATTE, J.L.I., 1975. Caracteristics and classification of a toposequence of soils near Piracicaba, Brazil. Tese de Ph.D. Columbus, Ohio State University. 298 p. (Não publi cada).

DEMATTE, J.L:I.; L.P. WILDING e N. HOLOWAYCHUK, 1977. Solos da região de São Pedro, Estado de São Paulo. III. Micromor fologia. R. bras. Ci. Solo, Campinas, 1: 104-107.

DESHPAND, T.L.; D.L. GREENLAND e J.P. QUIRK, 1968. Changes in soil properties associated with the removal of iron and aluminum oxides. J. Soil Sci., Edinburgh, 19: 108-122.

DE VILLERS, J.M., 1965. Present soil forming factors and pro cesses in tropical and subtropical regions. Soil Sci., Bal timore, 99: 50-57.

DIXON, J.B., 1966. Quantitative analysis of kaolinite and gibbsite in soils by differential thermal and selective dissolution methods. In: NATIONAL CONFERENCE CLAYS AND CLAY MINERAL, 14. Canadá, 1965. Proceedings. New York, Pergamon Press. p. 83-98. 
DUCHAUfOUR, P., 1977. Pédogènese et classification. Masson Paris, 477p. Apud. LIMA, J.M.J.C., 1979. Estudo de uma sequência de solos desenvolvidos de rochas básicas do sudoeste do Estado do Paraná. Dissertação de Mestrado, Esco la Superior de Agricultura "Luiz de Queiróz". Piracicaba, SP, Brasil, 123p. (Não publicado).

EL-ATTAR, H.A.; J.K. SYERS e M.L. JACKSON, 1969. Kaolinite determination by seletive dissolution analysis. Madison, University of Wisconsin, 29p.

ELLERT, R., 1959. Contribuição a geologia do maciço alcalino de Poços de Caldas. São Paulo, Faculdade de Filosofia, Ciências e Letras (USP-FFCL), p.1-63 (Boletim no 237).

EMPRESA BRASILEIRA DE PESQUISA AGROPECUARIA. ServiçO Nacional de Levantamento e Conservação de Solos. 1979. Manual de Métodos de Análises de Solos. Rio de Janeiro.

EMPRESA BRASILEIRA DE PESQUISA AGROPECUARIA. Serviço Nacional de Levantamento e Conservação de Solos. 1980a. Levantamento de reconhecimento dos solos do Estado do Paraná. Rio de Janeiro (No prelo).

EMPRESA BRASILEIRA DE PESQUISA AGROPECUARIA. Serviço Nacional de Revantamento e Conservação de Solos. 1980b. Estudo expedito de Solos do Estado de Santa Catarina, para fins de. classificação, correlação e legenda preliminar. Rio de Ja neiro. $155 \mathrm{p}$.

EMPRESA BRASILEIRA DE PESQUISA AGROPECUARIA. ServiçO Nacional de Levantamento e Conservação de Solos. 1982. Guia de excursão de estudos de solos nos estados do Rio de Janeiro, Minas Gerais e São Paulo. Rio de Janeiro. $107 p$.

ESWARAN, H.: 1972. Micromorphological indicators of pedogene sis in some tropical soil derived form basalt from Nicara gua. Geoderma, Amsterdam, 7: 15-31. 
ESTADOS UNIDOS. Department of Agriculture. Soil Survey Staff. 1975. Soil Taxonomy; A basic system of soil classifica tion for maping and interpreting soil survey. Washington. 754 p. (Agriculture Handbook, 436).

FEY, M.V. e L. LE ROUX, 1977. Properties and quantitative es timation of poorly crystalline components in sesquioxidic soil clays. Clays and Clay Minerals. Pergamon Press. 25: 285-294.

FINKL Jr.; C.W. e R.J. GILKES, 1976. Relationships between micromorphological soil features and knowns stratigraphic layers in western Australia. Geoderma. Amsterdam. 15: 179-208.

FITZPATRICK, R.W. e U. SCHWERTMANN, 1982. Al-substituted goe thite an indicator of pedogenic and other weathering environments in South Africa. Geoderma. Amsterdam, 27: 335347 .

GALHEGO, H.R. e C.R. ESPINDOLA, 1976. Estudo mineralógico de solos da região de Botucatu - são Manuel, sP. I. A fração argila de perfis de Latossolos Vermelhos Amarelos fase are nosa. In: Congresso Brasileiro de Ciência do Solo, 159 . Campinas, SP, 1975. Anais Soc. Bras. Ci. Solo, Campinas, p. 439-445.

GALLEZ, A.; A.S.R. JUO e A.J. HERBILLON, 1976. Surface and charge characteristics of selected soils in the tropics. Soil Sci. Soc. Amer. J., Madison, 40: 601-608. 
GAMBLE, E.E. e R.B DANIELS, 1972. Iron and silica in ' water, acid anmonium oxalate and dithionite extracts of some North Caroline Coastal Plain Soils. Soil Sci. Sco. Amer. Proc. Madison, 36: 939-943.

GARDNER, L.R., 1972. Conditions for direct formation of gibbsit from K-feldspar-further discussion. Amer. Miner. 57: 294-300.

GILLMAN, G.P., 1974. The influence of net charge on water dis persible clay and sorbed sulphate. Austr. J. Soil. Res. , Melbourne, 12: 173-176.

GILLMAN, G.P. e G. UEHARA, 1980. Charge characteristics of soils with variable and permanent charge minerals: II. Experimental. Soil Sci. Soc. Amer. J. Madison, 44 : 252-255.

GOEDERT, W.J.; J.K. SYERS e R.B. COREY, 1976. Relações cauli nita-quartzo-gibbsita em solos desenvolvidos de basaltos no Rio Grande do Sul. In: Congresso Brasileiro de Ciência do Solo, 150 Campinas, SP, 1975. Anais, Soc. Bras. Ci. So1o, Campinas, p. 496-498.

GOH, R.M., 1980. Dynamics e stability of organic matter. In: TENG, B.K.G., ed. Soils with variable charge. New zealand Soc. Soil Sci. Palmerston North. Lower Hutt. p. 373-427.

GORSKY, V.A. e E. GORSKY, 1974. Contribuição à mineralogia e. petrografia do planalto de Poços de Caldas. Comissão Nacional de Energia Nuclear, Rio de Janeiro, 92 p. (Boletim no 13). 
GREENLAND, D.J.; J.M. OADES e T.J. SHERWIN, 1968. Electron microscope observations of iron oxides in some red soils. J. Soil Sci. Edinburg• 19: 123-126.

GRIM, R.F., 1968. Clay mineralogy. 2 ed. New York, McGraw Hill. 596 p.

HEILMAN, M.D.; D.L. CHARTER e C.L. GONZALEZ, 1965. The ethy lene glycol monoethyl ether (EGME) technique for determination soil-surface area. Soil Sci. Baltimore, 100: 409413.

HINGSTON, F.J.; A.M. POSNER A J.P. QUIRK, 1972. Anion adsorp tion by goethite and gibbsite. I. The role of the proton in determmining adsortion envelopes. J. Soil Sci., Oxford, 23: $177-192$.

HSU, P.H., 1963. Effect of initial pH, phosphate, and silica te on determination of aluminum with aluminon. Soil sci., Baltimore, 96: 230-238.

HSU, P.H., 1977. Aluminum hidroxides and oxyhydroxides. In: DIXON, J.B. e WEED, S.B. (eds), Mineralogy in soil envi ronments. Soil Science Society of America, Madison, p. 99143.

IGNATIEFF, V. e R. LEMOS, 1963. Some management aspects of more important soils, Soil Sci., Baltimore. 95: 243-249.

JACKSON, M.L.; S.A. TYLLER; A.L. WILLIS; O.A. BOURBEAU E R.P. PENNINGTON, 1948. Weathering sequence of clay-size mine rals in soils and sediments. I. The Journal of Phys. and Coll. Chem. Wạshington, D.C. , 52: 1257-1261. 
JACKSON, M.L. e G.D. SHERMAN, 1953. Chemical weathering of minerals in soils. In: NORMAN, A.C. ed. Advances... in agronomy. New York, Academic Press, v. 5, p. 219-318.

JACKSON, M.L., 1964. Clay transformation in soil genesis during the quaternary. Soil Sci. New Brunswick, 99: 15-22.

JACKSON, M.L., 1969. Soil chemical analysis; advanced course. Madison, University of Wisconsin. $894 \mathrm{p}$.

JANOT, G. e H. GIBERT, 1970. Etude des substitutions Al-Fe dans des roches lateritiques. B. Soc. Fr. Mineral. Cris tallogr. Paris. 94: 367-380.

JUNGERIUS, P.D. e T.W.M. LEVELT, 1964. Clay mineralogy of soils over sedimmentary rocks in Easten Nigeria. Soil Sci. Baltimore. 97 : 89-95.

KAMPF, N. e E. KLAMT, 1978. Mineralogia e gênese de Latossolos (oxisols) e solos Podzólicos da região Nordeste do Pla nalto Sul-Riograndense. R. bras. Ci. Solo, Campinas, 2: $68-73$.

KAMPF, N. e U. SCHWERTMANN, 1982. The 5-M-NaOH concentration treatment for iron oxides in soils. Clays and Clay Mine rals. 30 : 401-408.

KAMPF, N. e U. SCHWERTMANN, 1983. Relações entre óxidos de ferro e a cor em solos caoliniticos do Rio Grande do Sul. Rev. bras. Ci. Solo. Campinas, 7: 27-31.

KELLER, W.D., 1970. Environmental aspects of clay materials. Journal Sed. Petrol. $\underline{40}$ : 788-85.4. 
KENG,J.C.W.; G. UEHARA, 1974. Chemistry, mineralogy, and taxonomy of oxisolos e ultisolos. Soil Crop Sci. Soc. Flo rida, Proc. 33: 119-126.

KITTRICK, J.A., 1969. Soil minerals in the $\mathrm{Al}_{2} \mathrm{O}_{3} \mathrm{SiO}_{2} \mathrm{H}_{2} \mathrm{O}$ system and a theory of their formation. Clays and clay. Minerals, 17: 157-167.

KRISHNA MURTI, G.S.; V.V. VOLK e M.L. JACKSON, 1966. Colorimetric determination of iron mixed valency by orthophena troline. Soil Sci. Soc. Amer. Proc. Madison, 30: 663-664.

LEPSCH, I.F.; S.W. BUOL e R.B. DANIELS, 1977b. Soil landscape relationships in the Occidental Plateau of são Paulo state, Brazil. II. Soil morphology, genesis and classification. Soil Sci. Soc. Amer. J. Madison, 4ll: 109-115.

LE ROUX, J., 1973. Quantitative clay mineralogical analysis of Natal Oxisols. Soil Sci., Baltimore, 115: 137-144.

LIMA, J.M.J.C., 1979. Estudo de uma sequência de solos desenvolvidos de rochas básicas do sudoeste do Estado do Paraná. Dissertação de Mestrado, Escola Superior de Agricultura "Luiz de Queiroz", Piracicaba, SP, Brasil. 123 p. (Não publicado) •

LINDSAY, 1982. Chemical equilibria in soils. John Wiley e Sons, New York, $423 \mathrm{p}$.

MAIGNIEN, R., 1958. Le cuirassement des sols en Guineé. Mém. Serv. Carte Geol. Als. Loss no 16. Strasburb. 239 p. Apud: VOLKOF, B, 1978. Os produtos ferruginosos que determinam a cor dos latossolos da Bahia. R. bras.Ci. Solo, Campinas, 2.: 55-59. 
MEKARU, T. e G. UEHARA, 1972. Anion adsorption in ferruginous tropicail soils. Soil Sci. Soc. Amer. Proc., Madison, 36: 296-300.

MCKEAGUE, J.A. e J.H. DAY, 1966. Dithionite and oxalate extractable $F e$ and $A l$ as aids in differentiating various classes of soils. Can. J. Soil Sci. Ottawa, 46: 13-22.

MCKEAGUE, J.A., 1967. An evaluation of 0,1M pyrophosphate and pyrophosphate-dithionite in comparison with oxalate as extractable of the acumulation products in podzol and some other soils. Can. J.Soil Sci., Ottawa, 47: 95-99.

MCKEAGUE, J.A.; J.E. BRYDON e N.M. MILES, 1971. Differentiating of forms extractable iron and aluminium in soils. Soil Sci. Soc. Amer. Proc., Madison, 35: 33-38.

MEHRA, O.P. e M.L. JACKSON, 1960. Iron oxide removal from soils and clays by dithionite citrate system buffered with sodium bicarbonate. In: NATIONAL CONFERENCE ON CLAYS AND CLAY MINERALS, 7, Washington, 1958. Proceedings. New York Pergamon Press, p. 317-327.

MELFI, A.J. e V.A.V. GIRARDI, 1962. Ocorrência de um sill de diabásio no arenito Botucatu, municỉpio de Igarapava, SP. Bol.Soc. Bras. Geol., 11: 55-70.

MENDES, A.C.T.; S.C. FALCI e J.L.I. DEMATTÊ, 1973. Seções del gadas de solos: método de impregnação. Anais da Escola Superior de Agricultura "Luiz de Queiroz", Piracicaba, SP, 30: 35-48. 
MOLLER, M.R.F. e E. KLAMT, 1982. Identificação e gênese de ar gilominerais em Latossolo. Roxo de Santo Angelo (RS) . R.bras. Ci. Solo. Campinas, $\underline{6}$ : 161-166.

MONIZ, A.C. e M.L. JACKSON, 1967. Quantitative mineralogical. of brapilian soils derived from basic rocks and slate. Madison, University of Wisconsin. 74 p. (Wisconsin Soil Scien ce Report, 212).

- MONIZ, A.C., 1969. Estudo mineralógico de argilas do macico alcalino de Poços de Caldas. São Paulo, Fáculdade de Filosofia, Ciências e Letras -USP, 134 p. (Boletim no 304).

MONIZ, A.C. e J.B. OLIVEIRA, 1974. Estudo mineralógico de solos derivados de rochas ínneas básicas da Estação Experimen tal de Ribeirão Preto, SP. In: Congresso Brasileiro de Ciência do Solo, 149, Santa Maria, RS, 1973. Anais, Soc. Bras. Ci. Solo, Santa Maria, p. 591-60l.

MONIZ, A.C. e S.W. BUOL, 1982 . Formation of an oxisol-ulti sol transition in São Paulo, Brazil: I. Double-water flaw model of soil development. Soil Sci. Soc. Amer. J. Madison, 46: $1228-1233$.

MONIZ, A.C.; S.W. BUOL e S.B. WEED, 1982 . Formation of an oxisol-ultisol transitionin São Paulo, Brazil: II. Lateral dynamics of chemical weathering. Soil Sci. Soc. Amer. J. Madison, 46: 1234-1239.

MOORE, T.R., 1973. The distribution of iron, manganese and alu minum in some soils from North-East Scotland. J. Soil Sci. Edinburgh, 16: 192-209. 
MORAIS, F.I.; A.L. PAGE e L.J. LUND, 1976. The effect of pH, salt conciatration e nature of electrolytes on the charge characteristics of brazilian tropical soils. Soil Sci.soc. Am. J., Madison, 40 : 521-527.

MOREIRA, A.A.N. e C. CAMELIER, 1977. Relevo. ' In: FUNDAÇÃO INSTITUTO BRASILEIRO DE GEOGRAFIA E ESTATISTICA. Geogra fia do Brasil - Região Sudeste. Rio de Janeiro. V.3. Região Sudeste, p. 1-50.

MOURA FILHO, W. e S.W. BUOL, 1972. Studes of a Latosol Roxo (Eutrustox) in Brazil: Clay mineralogy. Experientae. Viçosa. 13: 218-234.

NIMER, E., 1977. Clima. In: FUNDAÇÃO INSTITUTO BRASILEIRO DE GEOGRAFIA E ESTATISTICA. Geografia do Brasil - Região Sudeste. Rio de Janeiro. V.3. Região Sudeste, p. 51-90.

NORRISH. K. e R.M. TAYLOR, 1961. The isomorphous replecement of iron by aluminium in soil goethites. J. Soil Sci., Ottawa, 12: 294-306.

OJANUGA, A.G. e K. WIRTH, 1977. Treefold stonelines in South western Nigeria: evidence of cyclic soil e landscape development. Soil Sci. Baltimore, 123: 249-257.

OLIVEIRA, J.B.; R.R. ALFONSI e M.P. PEDRO JUNIOR, 1976. Regí mes hỉdricos e térmico dos solos do Estado de são Paulo.In: Congresso Brasileiro de Ciência do Solo, 150, Campinas, SP, 1975, Anais. Soc. Bras. Ci. Solo, Campinas, 352-359.

OLLIVIER, C.D., 1959. A two cycle theory of tropical pedology. Journal Soil Science, Edinburgh, 10: 137-148. 
PARFITT, R.L., 1980. Chemical properties of variable charge soils. In: THENG. B.K.G. ed. Soils with variable charge. New Zealand Society of Soil Science. Palmerston North, Lo wer Hutt, p. 167-194.

PARKS, G.A. e P.L. de BRUYN, 1962. The zero point of charge of oxides. J. Phys. Chem., 66: 967-973.

PARKS, G.A., 1967. The isoletric points of solid oxides, solid hïdroxides and aqueous hydroxi complex systems. Chem. Revs. 6.5:177-198

PEDRO, G., 1966. Essai sur la caracterization gēochimique des diferents processus zonaux résultant de l'altération géochimique des roches superficielles. C.R.Ac. Sci. Paris. 1292D: 1828-1831. Apud: ANTONELLO, L.L., 1982. Gênese de uma sequência de solos de rochas alcalinas do maciço alcalino de Itatiaia., RJ.: Mineralogia, geoquímica e micromorfologia. Tese de Doutorado. Universidade Federal do Rio de Janeiro. Rio de Janeiro, 262 p.

PENTEADO, M.M., 1983. Fundamentos de geomorfologia. FUNDAÇÃO INSTITUTO BRASILEIRO DE GEOGRAFIA E ESTATISTICA. RiO de Janeiro, $185 \mathrm{p}$.

PESSOA, S.C.P., 1979. Estudo de uma sequência de perfis de podzólicos e latossolos desenvolvidos de granulitos, na zona úmida costeira Sul do Estado da Bahia. Dissertação de Mestrado. Universidade Federal da Bahia. Salvador, BA, $146 \mathrm{p}$.

POMBO, L.C.A.; E. KLAMT; I. KUNRATH e D. GIANLUPPI, 1982. Iden ficação de ôxidos de ferro na fração argila de Latossolo Roxo. R. bras. Ci. Solo. Campinas, $\underline{6}: 13-17$. 
POTTER, R.O., 1977. Caracterização de solos da região dos cam-: pos de cima da serra - RS. Tese (Mestrado-Agron.-solos) Fac. Agronomia, UFRGS, Porto Alegre, Brasil. (Não publicada).

PRATI, P.F., 1965. Digestion with hydrofluoric e perchloric acids for total potassium acid sodium. In: BLACK, C.A. ed. Methods of Soil Analysis, Part 2. American Society of Agronomy, Madison, 1019-1021.

RESENDE, M., 1976. Mineralogy, chemistry, morphology and geomorphology of some soils of the Central Plateau of Brazil. Tese Ph.D., Lafayette, Purdue University. 237 p.

RODRIGUES, T.E., 1977. Mineralogia e gênese de uma sequência de solos dos cerrados, no Distrito Federal. Tese (Mestr. Agron. Solos). Faculdade de Agronomia, UFRGs. Porto Alegre, 101 p. (Não publicada).

RUHE, R.W., 1956. Landscape evolution in the high Ituri Bel gian Congo. Serie Scientifique no 66. INEAC. Bruxellas.

RUHE, R.W., 1960. Elements of soil landscape. In: INTERNATIO NAL CONGRESS OF SOIL SCIENCE. Transactions, Madison. International Society of Soil Science. V. 4. p. 165-170.

RUZICKA, J.; J.W.B. STEWART e E.A.G. ZAGATTO, 1976. Flow in jection analysis. Part IV. Stream sample splirtting and its aplication to the continuous spectrophotometric determi nation of cloride in brackish waters. Analytica Chimica. Acta, 81: 387-396.

SCHOFIELD, R.K., 1949. Effect of pH on electric charges car ried by clay particles. J. Soil Sci., Oxford, 1: 1-8. 
SCHWERTMANN, U., 1964. The differentiation of iron oxides in soils by a photochemical extraction with acid ammonium oxa late. Z. Pflanzener nahr Dung. Bodenkund, 105: 194-201. Abstract in Soil Fert. 28: 28.

SCHWERTMANN, U., 1971. Transformation of hematite to goethite in soils. Nature, Londres, . 232: 624-625.

SCHWERTMANN, U. e R.M. TAYLOR, 1977. Iron oxides. In: DIXON, J.B., ed. Minerals in soil enviroments. Soil Science Society of America, Madison, Wisconsin, p. 145-180.

SCHWERTMANN, U.; E. MURAD ED.G. SCHULZE, 1982. Is there Holo cene reddening (hematite formation) in soils of axeric tem perature areas? Geoderma, Amsterdam. 27: 209-223.

SCHWERTMANN, U., 1983. The role of aluminum in iron oxide sys tems. In: MELFI, A.J. e CARVALHO, A. ed. Lateritization. Processes. International Seminar Laterization. Processes IIo, 1982, USP. São Paulo. p. 65-68.

SCHWERTMANN, U.; W.R. FISCHER e H. PAPENDORF, 1968. The influ ence of organic compounds on the formation of iron oxides. In: INTERNATIONAL CONGRESS OF SOIL SCIENCE, 9, Adelaide,1968. Transactions, New York, American Elsevier, V.l, p.645-656.

SHERMAN, G.D.; Y. MATUSUSAKA; H. IKAWA e G. UEHARA, 1964. The role of amorphous fraction in the properties of tropical soils. Agrochimica, 7: 146-163. 
SIEFFERMANN, G. e G. MILLOT, 1969. Equatorial and tropical weathering of recent basalts form Cameroon: allophanes, hal loysite, kaolinite and gibbsite. In: INTERNATIONAL CLAY CONFERENCE. Proceedings. Tokio, 1969. Israel Universities Press. Jerusalem, 417-430.

THIESEN, A.A. e M.E. HARWARD, 1962. A paste method for preparation of slides for clay mineral identification by $x$-ray diffraction. Soil Sci. Soc. Amer. Proc., Madison, 26: 9091 .

TOKASHIKI, Y. e K. WADA, 1975. Weathering implications of the mineralogy of clay fractions of two and soils, KYUSHU. Geoderma, Amsterdam, 14: 47-62.

TORRENT, J.; U. SCHWERTMANN, e D.G. SCHULZE, 1980. Iron oxide mineralogy of some soils of two river terrace sequences in spain. Geoderma, Amsterdam, 23: 191-208.

UEHARA, G. e G.P. GILLMAN, 1981. Mineralogy chemistry, and physics of tropical soils with variable charge clays. Boul der, Westview Press, 170 p.

UEHARA, G. e J. KENG, 1975. Manegement implications of mineralogy in Latin America. In: BORNEMISZA, E. e ALVARADO, A. (ed.), Soil Management in Tropical America. North Carolina State University, Raleigh. p. 351-363.

VAN DIJK, H., 1971. Colloid chemical properties of humic matter. In: H.D. McLAREN and J. SKUJINS (editors). Soil biochemistry, V.2, Marcel Dekker, New York p. 16-35. Apud: GOH, K.M., 1980, Dynamics and stability of organic matter. In: TENG, B.T.K (editors), 1980. Soils with variable charge. New Zealand Society of Soil Science, Lowes Hutt p. 373-393. 
VAN OLPHEN, H., 1963. Introduction to clay colloid chemistry. Interscience. New York. $301 \mathrm{p}$.

VAN RAIJ, B. e M. PEECH, 1972. Electrochemical properties of some oxisolos e alfisolos of the tropics. Soil Sci.Soc.Amer. Proc., Madison, 36: 587-593.

VAN WAMBEKE, A., 1962. Criteria for classifying soils by age. J.Soil Sci. Edinburg, 13: 124-132.

VETTORI, L., 1969. Métodos de análise de solo. Rio de Janeiro. Ministério da Agricultura. Equipe de Pedologia e Fertilidade do Solo. Escritório de Pesquisa e Experimentação. 24 p. (Boletim Técnico, 7).

VETTORI, L., 1975. Ferro "livre" por cálculo. In: Congresso Brasileiro de Ciência do Solo, 150, Campinas, SP, 1975, Anais, Soc. Bras. Ci. Solo, Campinas, p. 127-128.

VOLKOFF, B., 1977. La matiere organique des sols ferralliti ques du Nordeste du Brasil. Cahiers ORSTON, Série Pédoİ., Paris, 15: $61-75$.

VOLKOFF, B., 1978. Os produtos ferruginosos que determinam a cor dos Latossolos da Bahia. R. bras. Ci. Solo, Campinas, 2. $55-59$.

VOLKOFF, B. e L.P. RIBEIRO, 1979. O ferro em solos vermelhos latossólicos e podzólicos da região de Jequié (BA). R.bras. Ci. Solo, Campinas, $\underline{3}$ : 162-168.

VOLKOFF, B. e C.C. CERRI, 1981. Humus em solos da floresta amazônica na região do Rio Madeira. R. bras. Ci. Solo, Cam pinas, $\underline{5}: 15-21$. 
WEAVER, R.M.; J.K. SYERS E M.L. JACKSON, 1968. Determination of silica in citrate-bicarbonate-dithionite extracts of soils. Soil Sci. Søc. Amer. Proc., Madison, 32: 497-501.

WEAVER, R.M., 1974. Soils of the Central Plateau of Brazil: Chemical and mineralogical properties. New York, Ithaca Cornell University. 45. p. (Agronomy mineo 74-8).

WEBER, B.N., 1959. Bauxitização no distrito de Poços de Caldas, Minas Gerais, Brasil. Bol. Soc. Bras. Geol., 8: 17 30 .

WILSON, M.J., 1969. A gibbsite soil from the weathering of an ultrabasic rock on the island of Rhum. Scott. J. Geol. 5: $81-9$. 
194.

9. APENDICES 
195.

APENDICE I 
Perfil:

PC-1

Data:

$25 / 07 / 81$

Classificação: CAMBISSOLO ÁLICO, argila de baixa atividade A proeminente muito argiloso, fase campo cerrado relevo ondulado (LATOSSOLO VERMELHO AMARELO ÁLI CO cânbico A proeminente muito argiloso fase campo cer rado, relevo ondulado).

Unidade de mapeamento:

Localização, município, estado e coordenadas: A $7 \mathrm{~km}$ de Cascata, na Fazenda Sobradinho, na estrada para a Fazenda Genipapo, Águas da Prata, SP.

Situação, declive e cobertura vegetal sobre o pèfil: Trincheira no terço superior da elevação, com $10 \%$ de declive, sob campo natural (campo cerrado).

Altitude: $\quad 1290 \mathrm{~m}$.

Litologia: Rochas alcalinas.

Formação geológica: Complexo alcalino de Poços de Caldas.

Cronologia: Cretāceo (?)

Material originārio: Material resultante da alteração de tin guaitos e fonolitos com lentes de bostolitos.

Pedregosidade: Não pedregosa.

Rochosidade: Não rochosa. 
Relevo local: Ondulado.

Relevo regional: Forte ondulado.

Erosão: Ligeira.

Drenagem: Bem drenado.

Vegetação primāria: Campo cerrado.

Uso atual: Pasto natural.

Clima: Mesotérmico brando subúmido.

Descrito e coletado por: Tarcísio Ewerton Rodrigues e.Humber to Gonçalves dos Santos.

Al $0-12 \mathrm{~cm}$; bruno escuro (7,5YR 3/2, úmido) e bruno ama relado escuro (10YR $4,5 / 2$, seco); franco argiloso; forte pequena e média granular; muito du ro, muito firme, plástico e pegajoso; transi ção plana e gradual.

A3 12- $23 \mathrm{~cm}$; bruno escuro (lOYR 3/3, úmido) muito argilo so e bruno acinzentado (lOYR 5/2, seco); franco argiloso; forte pequena a grande bloco subangular; superfície fosca (?); extremamente du ro, muito firme, plástico e pegajoso; transi ção plana e clara.

B21 23- $45 \mathrm{~cm}$; bruno amarelado escuro (lOYR 4/4, úmido); mui to argiloso; moderada pequena a grande bloco subangular; cerosidade fraca e comum (?); extre mamente duro, muito firme, plástico e muito pe gajoso; transição plana e gradual. 
B22 45- $65 \mathrm{~cm}$; bruno avermelhado (5YR 5/4, úmido); muito ar giloso; fraca a moderada pequena a grande bloco subangular; cerosidade fraca a moderada comum (?); extremamente duro, fịrme, plástico e muito pega joso; transição plana e gradual.

B3

65-115 cm; vermelho amarelado (5YR 4/6 úmido); argila siltosa; fraca a moderada pequena a média bloco subangular; cerosidade comum (?); extremamente duro, firme, plástico e muito pegajoso; transição plana e gradual.

Cl 15-175 cm; bruno avermelhado (5YR 5/3, úmido), com mos queado abundante pequeno e médio preminente ver melho (2,5YR 5/6, úmido), cinzento N5/ e bruno forte (7,5YR 5/8, úmido); franco argilo siltoso; maciça, muito duro, friável a firme; plástico e pegajoso.

C2 175-265+cm; bruno amarelado (1OYR 5/4, úmido) e cinzento (N6/, úmido); franco argilo siltoso; plástico e pegajoso.

Raỉzes:

Finas abundantes no Al, muitas no A3 e B2l, Comuns B22 e poucas no B3 e raras no $\mathrm{Cl}$.

Observações: Poros: muito pequenos a grandes muitos no Al, co muns no A3; pequenos a grandes muitos no B21, $\mathrm{B} 22, \mathrm{~B} 3 \mathrm{e} \mathrm{Cl}$.

A atividade de organismo é comum em todo o perfil. Presença de concreções dispersas em linha no topo do horizonte B23, O horizonte C2 foi co letado com auxílio de trado. A cerosidade desa parece no solo seco. 
PERFIL PC-I

ANALISES FISICASE QUIMICAS

Amostre de labor. n.o: $\quad 81.2620 / 1626$

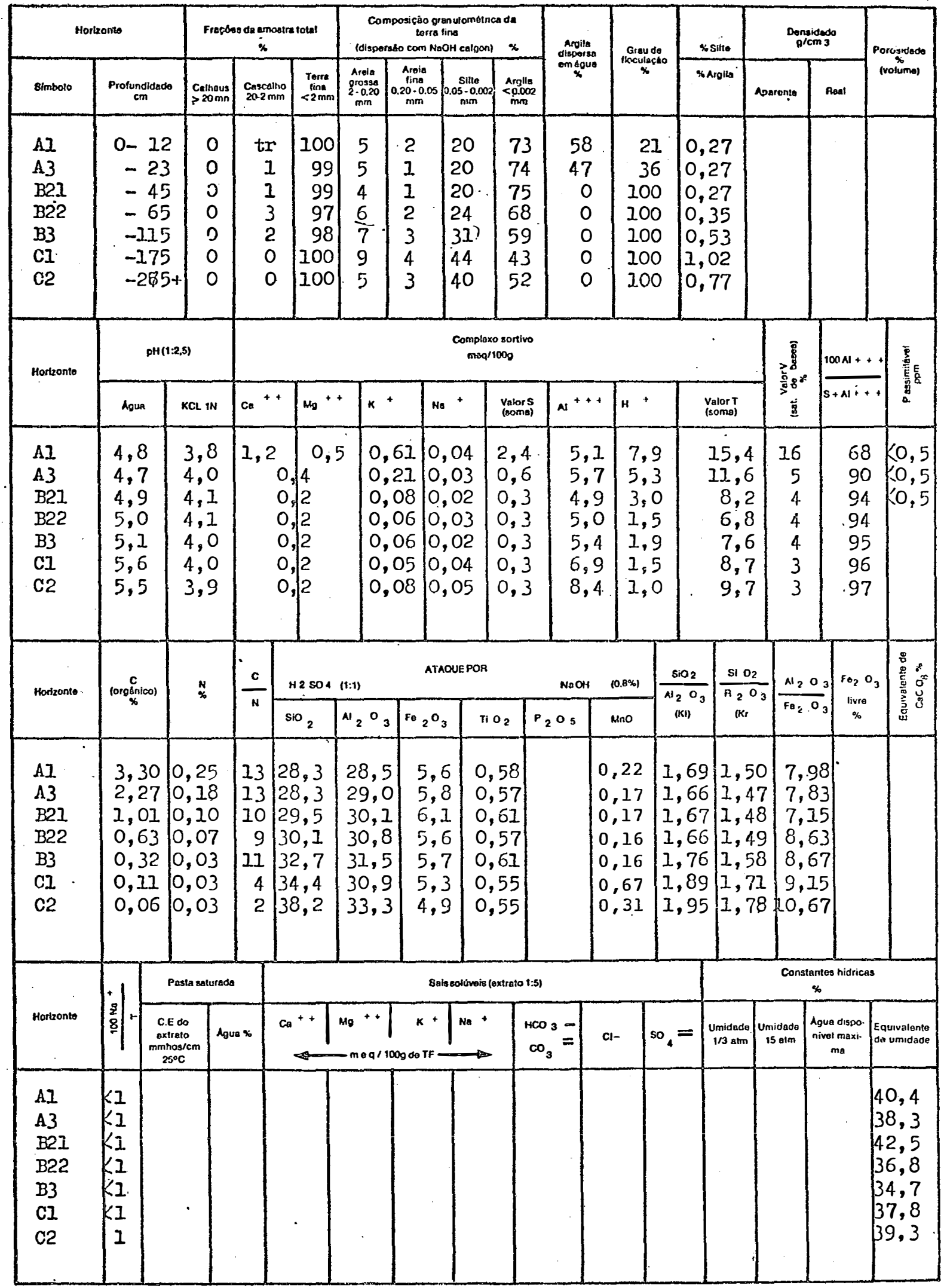


Perfil: $\quad$ PC-2

Data :

$25 / 07 / 81$

Classificação: TERRA BRUNA ESTRUTURADA ÁLICA argila de baixa atividade $A$ proeminente muito argilosa fase cam po cerrado relevo suave ondulado (LATOSSOLO BRU NO ÁLICO câmbico A próminente muito argiloso fasecampo cerrado relevo suave ondulado).

Unidade de mapeamento:

Localização, município, estado e coordenadas: A 7 km de Casca ta, na Fazenda Sobradinho, na estrada para a Fa zenda Genipapo, Poços de Caldas, MG.

Situação, declive e cobertura vegetal sobre o perfil: Trin cheira em terço médio de elevação em declive de $5 \%$, sob cultura de milho.

Altitude: $\quad 1270 \mathrm{~m}$.

Litologia: Rochas alcalinas.

Formação geológica: Complexo alcalino de Poços de Caldas.

Cronologia: Cretáceo (?)

Material originário: material proveniente da alteração de tin guaitos e fonolitos com lentes de bostolitos.

Pedregosidade: Não pedregosa.

Rochosidade: Não rochosa. 
Relevo local: Suave ondulado.

Relevo regional: Forte ondulado.

Erosão:

Drenagem:

\section{Ligeira.}

Bem a moderaciamente drenado.

Vegetação primária: Campo cerrado.

Uso atual: Culturas de milho, batata, etc.

Clima: Mesotérmico brando subúmido.

Descrito e coletado por: Tarcísio Ewerton Rodrigues e Humber-to Gonçalves dos Santos.

Ap $\quad 0-19 \mathrm{~cm}$; bruno escuro (7,5YR 3/2, úmido) e bruno (lOYR 5/3, seco); muito argiloso; forte muito pequena a média granular; duro, firme, muito plástico e muito pegajoso; transição plana e gradual.

A3 19- $35 \mathrm{~cm}$; bruno escuro (lOYR 3/3, úmido) e bruno (lOYR 5/3, seco); muito argiloso; forte pequena a média, granular e bloco subangular, supe $\underline{r}$ fỉcie foscas; muito duro, firme, muito plástico e muito pegajoso, transição plana e clara.

B21 35- $52 \mathrm{~cm}$; bruno amarelado escuro (lOYR 4/4, úmido); mui to argiloso; moderada média prismática desfazen do-se em moderada pequena a grande bloco subangular; cerosidade fraca e comum (?); muito duro, firme, plástico e muito pegajoso; transição plä na e gradual. 
B22 52- $79 \mathrm{~cm}$; bruno (7,5YR 4/4, úmido); muito argiloso ; moderada médio prismática desfazendo-se em moderada pequena a grande bloco subangular; cero sidade fraca e comum (?); extremamente duro, firme, plástico e muito pegajoso, transição plana e gradual.

B3 79-105 cm; bruno (7,5YR 5/2, úmido), com mosqueado pou co pequeno difuso (7,5YR 5/4, úmido); argila siltosa; moderada média a grände prismática; su perfície de fricção, extremamente duro; muito firme, plástico e pegajoso; transição plana e clara.

Cl 105-210 cm; cinzento (5YR 5/1,5, úmido), com mosqueado pouco médio distinto bruno $(7,5 Y \mathrm{R} 5 / 4$, úmido); argila siltosa; extremamente duro, muito firme, plástico e pegajoso; transição plana e difusa.

C2 210-280+cm; coloração variegada; cinzento claro (10YR 7/2, úmido), bruno (10YR 5/4, úmido) e cinzento escuro (lOYR 4/1, úmido); argila siltosa ; plástico e pegajoso.

Raizes : F.inas abundantes no Ap, muitas no A3, poucas no $B 21$ e raras no B22.

Observações: Poros: muito pequenos e pequenos muitos no Ap, muito pequenos a médios no $A 3, B 21$; pequenos $e$ médios muitos no B22, B23 e B3; médios a grandes comuns no $\mathrm{Cl}$. Presença de concreções irregu lares distribuidas em linha no topo do B22. 0 material do $\mathrm{A} 3$ penetrando no B2l. A atividade biológica é comum no perfil. A estrutura do B3 
e cl e em cortes próximos ao perfil é prismáti ca quando seco o solo. A cerosidade vista no solo úmido, desaparece nos cortes secos. 0 C2 foi coletado com trado. Perfil descrito com tempo nublado. 
PERFIL FC-2

ANALISES FISICASE QUIMICAS

Amostra de labor. n.o: $\quad 81.2627 / 1633$

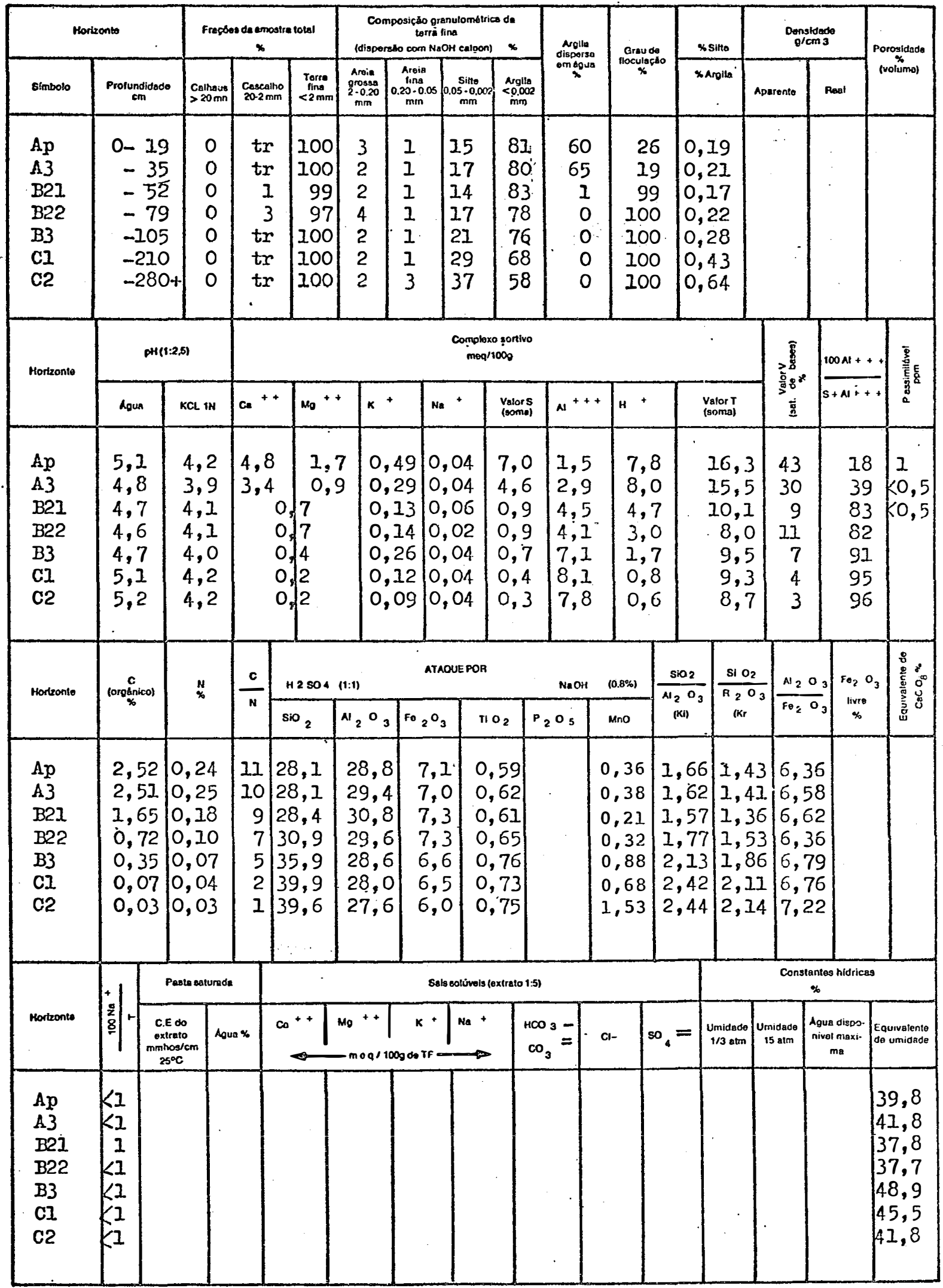


Perfil: $\quad$ PC-3

Data:

$27 / 07 / 81$

Classificação: LATOSSOLO BRUNO DISTROFICO A proeminente muito argiloso fase campo cerrado reḷevo suave ondulado (LATOSSOLO VERMELHO AMARELO Distrófico A proeminente muito argiloso fase campo cerrado relevo suave ondulado).

Localização, município, estado e coordenadas: A $7 \mathrm{~km}$ de Cascata, na Fazenda Sobradinho, na estrada para Fazenda Genipapo, Poços de Caldas, MG.

Situação, declive e cobertura vegetal sobre o perfil: Trin cheira no terço inferior da encosta, em declive de $2,5 \%$, sob cultura de milho.

Altitude: $\quad 1240 \mathrm{~m}$.

Litologia: Rochas alcalinas.

Formação geológica: Complexo alcalino de Poços de Caldas.

Cronologia: Cretáceo (?) •

Material orignário: Material resultante da alteração de tinguaitos e fonolitos com lentes de bostolitos.

Pedregosidade: Não pedregosa.

Rochosidade: Não rochosa.

Relevo local: Suave ondulado. 
Relevo regional: Forte ondulado.

Erosão: $\quad$ Ligeira.

Drenagem: $\quad$ Bem a moderadamente drenado

Vegetação primária: Campo cerrado.

Uso atual: Culturas de milho, batata, etc.

Clima: Mesotérmico brando subúmido.

Descrito e coletado por: Tarcisio Ewerton Rodrigues e Humber to Gonçalves dos Santos.

Ap $\quad 0-25 \mathrm{~cm}$; bruno acinzentado muito escuro (10YR $3 / 2$, úmido) e bruno (10YR 4,5/3, seco); franco argi loso; moderada pequena e média granular e bloco subangular; muito friável, plástico e pegajoso; transição plana e gradual.

A3 25- $40 \mathrm{~cm}$; bruno escuro (10YR 3/3, úmido) e bruno (10YR $5,5 / 3$, seco); argila; moderada pequena e média bloco subangular e granular; friável, plástico e pegajosio; transição plana e clara.

Bl 40- $58 \mathrm{~cm}$; bruno forte $(7,5 \mathrm{YR} \mathrm{5/6,} \mathrm{úmico);} \mathrm{argila;} \mathrm{fra}$ ca muito pequena a média bloco subangular; duro, friável, plástico e pegajoso; transi ção plana e difusa. 
B21 58- $84 \mathrm{~cm}$; bruno forte $(7,5 \mathrm{YR} 5 / 7$. , úmido), com mosquea do pouco pequeno distinto vermelho amarelado (5YR 4/6, úmido); muito argiloso; fraca muito pequena a média blocọs subangular; duro, muito friável, plástico e pegajoso; transição plana e difusa.

- B22 84-110 cm; bruno forte (7,5YR 5/6, úmido), com mosquea do comum, médio proeminente bruno avenmelhado (2,5YR 4/4, úmido); muito argilcso; fraca muito pequena a pequena granular; duro, muito friável, plástico e pegajoso; transição pla na e gradual.

B23 110-153 cm; vermelho escuro (2,5YR 3/5; úmido); muito argiloso; fraca a moderada pequena a média blo co subangular; duro, friável, plástico e pe gajoso; transição plana e difusa.

B3 153-197 cm; vermelho amarelado (5YR 4/6, úmido), muito argiloso; fraca muito pequena a média, bloco subangular; duro, firme; plástico e pegajoso; transição plana e clara.

Cl 197-250 cm; vermelho amarelado (5YR 5/6, ümido), com mosqueado pouco pequeno distinto vermelho (2,5YR 4/6, úmido); argila; maciça; duro, fir me, plástico e pegajoso.

C2 250-290+cm: coloração variegada: vermelho amarelado (5YR $4 / 6$, úmido), vermelho (2,5YR 4/6, úmido) e bruno amarelado (10YR 5/4, úmido); argila; maciça; duro, firme, plástico e pegajoso. 
Raízes :

Finas muitas no Ap e A3; comuns no Bel e B2l; poucas no $\mathrm{B} 22$ e raras no B23.(?).

Observações: Presença de concreções (bauxita) na transição entre B22 e B23(?). Poros: muito pequeno é pequenos muitos no Ap e A3; muito pequeno a grande muitos no $\mathrm{B} 1, \mathrm{~B} 21, \mathrm{~B} 22, \mathrm{~B} 23$ e B3 e co muns no $\mathrm{Cl}$.

Na parte superior do B23 (?) há presença de melhor estrutura, assim como, cerosidade mode rada e comum (?) no B23 e fraca e pouca (?) no B3. A cerosidade desaparece no solo seco. Presença de concreções brandas no do $\mathrm{Bl}$ ao $\mathrm{Cl}$. Parte do $\mathrm{Cl}$ e todo o $\mathrm{C} 2$ foi coletado com trado. 
PERFIL PC-3

ANALISES FISICAS E QUIMICAS

Amostra de labor. n.: $\quad 81.1634 / 1642$

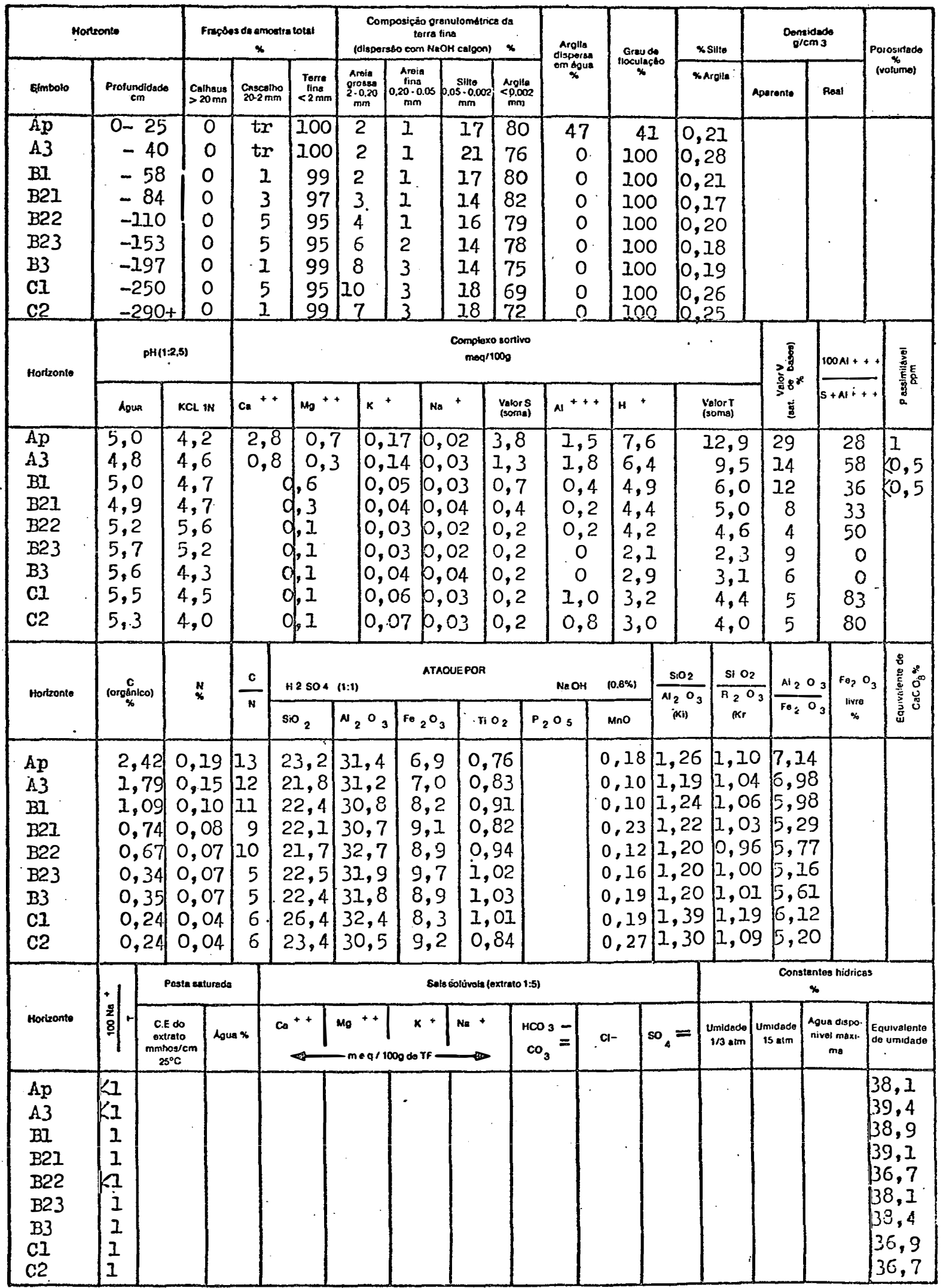


Perfil: $\quad$ PC -4

Data :

$23 / 10 / 81$

Classificação: LATOSSOLO BRUNO ÁLICO A proeminente muito argi loso fase campo cerrado relevo plano a suave ondulado. (LATOSSOLO VERMELHO AMARELO ÁLICO A proeminente muito argiloso fase campo cerrado relevo plano a suave ondulado).

Unidade de mapeamento:

Localizaçã̀o, município, estado e coordenadas: A $7 \mathrm{~km}$ de Cascata, Fazenda Sobradinho, na estrada para a Fa zenda Genipapo. Poços de Caldas, MG.

Situação, declive e cobertura vegetal sobre o perfil: Trincheira na parte inferior da elevação, com declive de $3 \%$, sob cultura de milho.

Altitude: $\quad 1200 \mathrm{n}$.

Litologia: Rochas alcalinas.

Formação geológíca: Complexo alaclino de Poços de Caldas.

Cronologia: Cretáceo (?).

Material originário: Material proveniente da alteração de tinguaitos e fonolitos com lentes de bostolito.

Pedregosidade: Não pedregosa.

Rochosidade: Não rochosa. 
Relevo local: Suave ondulado.

Relevo regional: Forte ondulado.

Erosão: $\quad$ Ligeira.

Drenagem: Bem a moderadamenic úrenado.

Vegetação primária: Campo cerrado.

Uso atual: Cultura de milho, batata, etc.

Clima: Mesotèrmico brando subúmido.

Descrito e coletado por: Tarcísio Ewerton Rodrigues e JoséLuiz: I. Demattê.

Ap $\quad 0-32 \mathrm{~cm}$ : bruno acinzentado muito escuro (1.0YR 3/2., úmido), bruno acinzentado (10YR 5/2, seco amassado); argila; fraca a moderada pequena e média granular e bloco subangular; muito duro, firme, muito plástico e mui.to pegajoso; transição plana e abrupta.

B21 32- $65 \mathrm{~cm}$; bruno escuro (7,5YR 4/4, úmido); argila; moderada . pequena e média bloco subangular; extremamente duro, firme, muito plástico e muito pegajoso; transição plana e clara.

B22 65-105 cm; bruno forte (7,5YR 4/6, úmido), muito argilo sa; moderada pequena e média bloco subangular; extremamente duro, firme, muito plástico e muito pegajoso; transição plana e clara. 
B23 105-120 cm; vermelho escuro $(2,5 Y \mathrm{R} 3 / 6$, úmido), muito ar giloso, moderada pequena e média bloco subangular; cerosidade fraca e pouca (?), extremamente duro, firme, muito plástico e muito pegajoso ; transição plana e gradual.

B24 120-150 cm; vermelho amarelado (5YR 4/6,úmido), com mosqueado pequeno comum e distinto bruno avermelha do escuro $(2,5$ YR 3/4, úmido) e médio comum proe minente bruno claro acinzentado (10YR 6/3, úmido); muito argiloso, fraca a moderada pequena e média blocos subangular; extremamente duro, fị me, muito plástico e muito pegajoso, transição plana e gradual.

B3 150-220+cm; vermelho (2,5YR 4/6, úmido); muito argilosio; extremamente duro, firme, muito plástico e muito pegajoso.

Raỉzes:

Finas muitas no Ap e comuns no $B 21$, poucas no B22 e B23.

Observações: Presença de linha de pedra entre o B22 e o B23. Poros e canais nuitos no perfil. Atividade de organismo muita no perfil. O horizonte B3 foi coletado com trado. A área na ocasião da coleta do perfil estava recém arada. A cerosidade desa parece no solo seco. 
PERFIL PC-4

ANALISES FISICAS E QUIMICAS

Amostra do labor. n.o: $81.2222 / 2227$

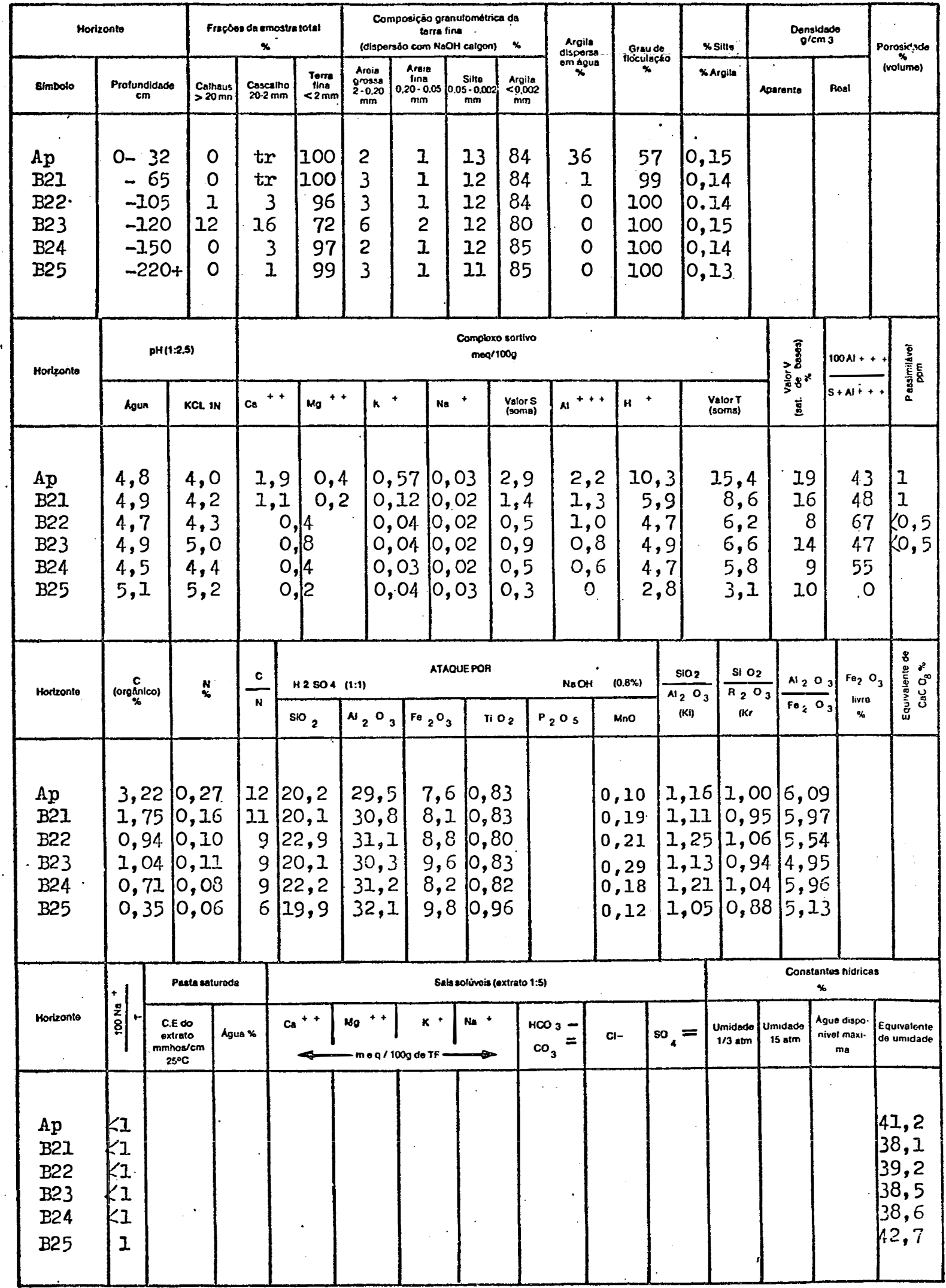


Perfil: $\quad$ PC -5

Data: $\quad 26 / 07 / 81$

Classificação: CAMBISSOLO ÁLICO argila de baixa atividade A moderado muito argiloso fase pedregosa I campo cerrado.

Unidade de mapeamento:

Localização, município, estado e coordenadas: A $31 \mathrm{~km}$ de Poços de Caldas, na Estrada para Anḍradas, a 1 $\mathrm{km}$ na estrada para Pocinhos e $500 \mathrm{~m}$ à esquerda desta ūltima, Andradas, MG.

Situação, declive e cobertura vegetal sobre o perfil: Trincheira no terço superior, em declive de $14 \%$, sob vegetação natural (campo cerrado).

Altitude: $\quad 1350 \mathrm{~m}$.

Litologia: $\quad$ Rochas alcalinas.

Formação geológica: Complexo alcalino de Poços de Caldas.

Cronologia: Cretāceo?

Material originário: Material resultante da alteração de lavas fonoliticas e foiaitos com lentes de anfibolitos.

Pedregosidade: Muito pedregosa.

Rochosidade: Não rochosa. 
Relevo local: Forte ondulado.

Relevo regional: Forte ondulado.

Erosão: $\quad$ Moderada .

Drenagem: Moderada.

Vegetação primária: Campo cerrado.

Uso atual: Pasto natural.

Clima: Mesotérmico brando subúmido.

Descrito e coletado por: Tarcísio Ewerton Rodrigues e Humber to Gonçalves dos Santos.

Alcn 0- $25 \mathrm{~cm}$; bruno escuro (7,5YR 4/2, úmido) e bruno ama relado (lOYR 5/4, seco); franco argiloso muito cascalhento; fraca a moderada pequena e média granular; duro, friável, plástico e pegajoso ; transição plana e clara.

B 25- $62 \mathrm{~cm}$; bruno forte (7,5YR 5/6, úmido), com mosquea do comum pequeno difuso amarelo avermelhado (7,5YR 6/7, úmido); muito argiloso com casca lho; fraca pequena a grande bloco subangular; extremamente duro, firme, plástico e pegajoso; transição plana e gradual.

C1 62-138 cm; amarelo avermelhado (5YR 6/7, úmido), com mosqueado abundante médio, proeminente cinzento claro (lOYR $7 / 2$, úmido) e comum pequeno proe minente vermelho $(2,5 \mathrm{YR} 5 / 6$, úmido); argila ; fraca média a grande bloco subangular; extremamente duro, firme, plástico e pegajoso. 
PERFIL PC-5.

Amostra de labor.n.:: 81.1643/1646

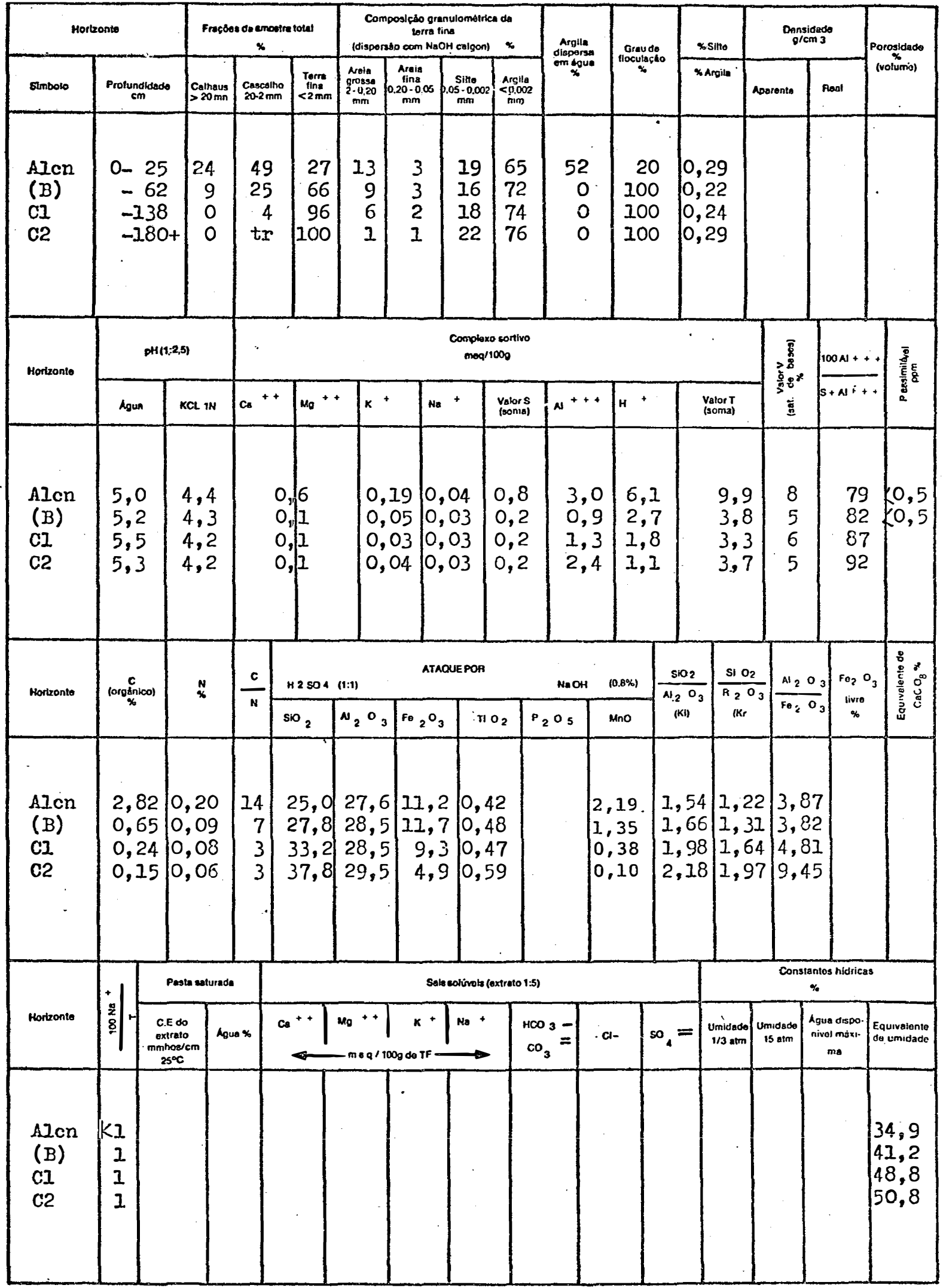


Perfil: $\quad$ PC-6

Data:

$2.7 / 07 / 81$

Classificação: CAMBISSOLO ÁLICO argila de baixa atividade A proeminente muito argiloso fase campo cerrado relevo forte ondulado (LATOSSOLO VERMELHO AMARELO ÁLICO A proeminente muito argiloso fase campo cerrado relevo forte ondulado).

Unidade de mapeamento:

Localização, município, estado e coordenadas: A $3.1 \mathrm{~km}$ de Poços de Caldas, na estrada para Andradas, a 1 $\mathrm{km}$ na estrada para Pocinhos e $500 \mathrm{~m}$ à esquerda desta última, Andradas, MG.

Situação, declive e cobertura vegetal sobre o perfil: Trin cheiṛa no terço médio da encosta, em declive de $8,5 \div$, sob cobertura de pasto natural.

Altitude: $\quad 1310 \mathrm{~m}$.

Litologia: Rochas alcalinas.

Formação geológica: Complexo alcalino de Poços de Caldas.

Cronologia: Cretāceo(?).

Material orignārio: Material resultante da alteração de lavas fonoliticas e foiaitos com lentes de anfibolitos.

Pedregosidade: Pedregoso. 
Rochosidade: Não rochoso:

Relevo local: Forte ondulado.

Relevo regional: Forte ondulado.

Erosão: $\quad$ Moderada.

Drenagem: $\quad$ Bèm drenado.

Vegetação primāria: Campo cerrado.

Uso atual: Pasto natural.

Clima: Mesotērmico brando subümido.

Descrito e coletado por: Tarcísio Ewerton Rodrigues e Humber to Gonçalves dos Santos.

Al $0-15 \mathrm{~cm}$; bruno escuro $(7,5 Y \mathrm{R} 3 / 2$, úmido) $:$ e bruno (10YR 5/3, seco); argila; forte muito pequena a média granular e blocos subangulares; extremamente duro, firme, plástico e pegajoso; tran sição plana e difusa.

A3 15- $27 \mathrm{~cm}$; bruno escuro (lOYR 3/3, úmido) e bruno amarelado (1OYR 5/4, seco); argila; moderada pe quena a média bloco subangular; extremamente duro, firme, plástico e pegajoso; transição pla na e clara. 
Bl 27- $48 \mathrm{~cm}$; bruno forte $(7,5 \mathrm{YR} 5 / 7$, úmido); argila; fraca a moderada pequena a média bloco subangular; cerosidade fraca e comum (?); extremamente duro, firme, plástico e muito pegajoso; transição plana e abrupta.

B2 cn 48- $90 \mathrm{~cm}$; bruno forte (7,5YR 5/8, úmido); argila muito cascalhenta; maciça (?); cerosidade fraca e comum (?); extremamente duro, firme, plástico e pegajoso; transição planà e abrupta.

B3 90-140+cm; amarelo avermelhado (5YR 6/8, úmido); muito argiloso; fraca a moderada média a grande bloco subangular; cerosidade fraca e comum; extremamente duro, firme, plástico e muito pegajoso.

Raízes : Finas abundantes em Al e A3, muitas em Bl raras no $\mathrm{B} 2 \mathrm{cn}$ e $\mathrm{B} 3$.

Observações: Poros: muito pequeno e pequeno muitos no $\mathrm{Al}, \mathrm{c} \underline{\mathrm{o}}$ mum no $\mathrm{A} 3$; muito pequeno a grande muitos no $\mathrm{Bl}$, $\mathrm{B} 2 \mathrm{cn}$ e B3.

A atividade biológica é comum no perfil. A cerosidade descrita no perfil úmido, não é obser vada no solo seco.

No solo seco a estrutura do B3 poderá ser prís mática. Presença de concreções dispersas no Bl e B3. No solo seco não foi observado cerosidade. Na parte inferior do horizonte B3 foi cons tatado a presença de fragmentos de rochas, não permitindo o alcance de maior profundidade. 
C2 138-180+cm; coloração variegada: bruno muito ! claro acinzentado (10YR 8/4, úmido), amarelo brunado (10YR 6/6, úmido) e amarelo brunado (7,5YR 6/8, úmido); argila; plástico e pegajoso.

Raĩzes :

Finas muitas no $\mathrm{Al}$, poucas e raras no $\mathrm{Cl}$..

Observações: Poros: muito pequeno a grande muitos no $\mathrm{B}$ e $\mathrm{Cl}$. Presença de grande quantidade de concreções no Al e topo do B. No Alcn é difícil a observa ção das características morfológicas devido as pedras. A atividade de organismo é comum no perfil. O C2 foi coletado com trado. 
PERFiL PC-6

ANALISES FISICAS E QUIMICAS

Amostra de labor.n.: $\quad$ 81.1647/1651

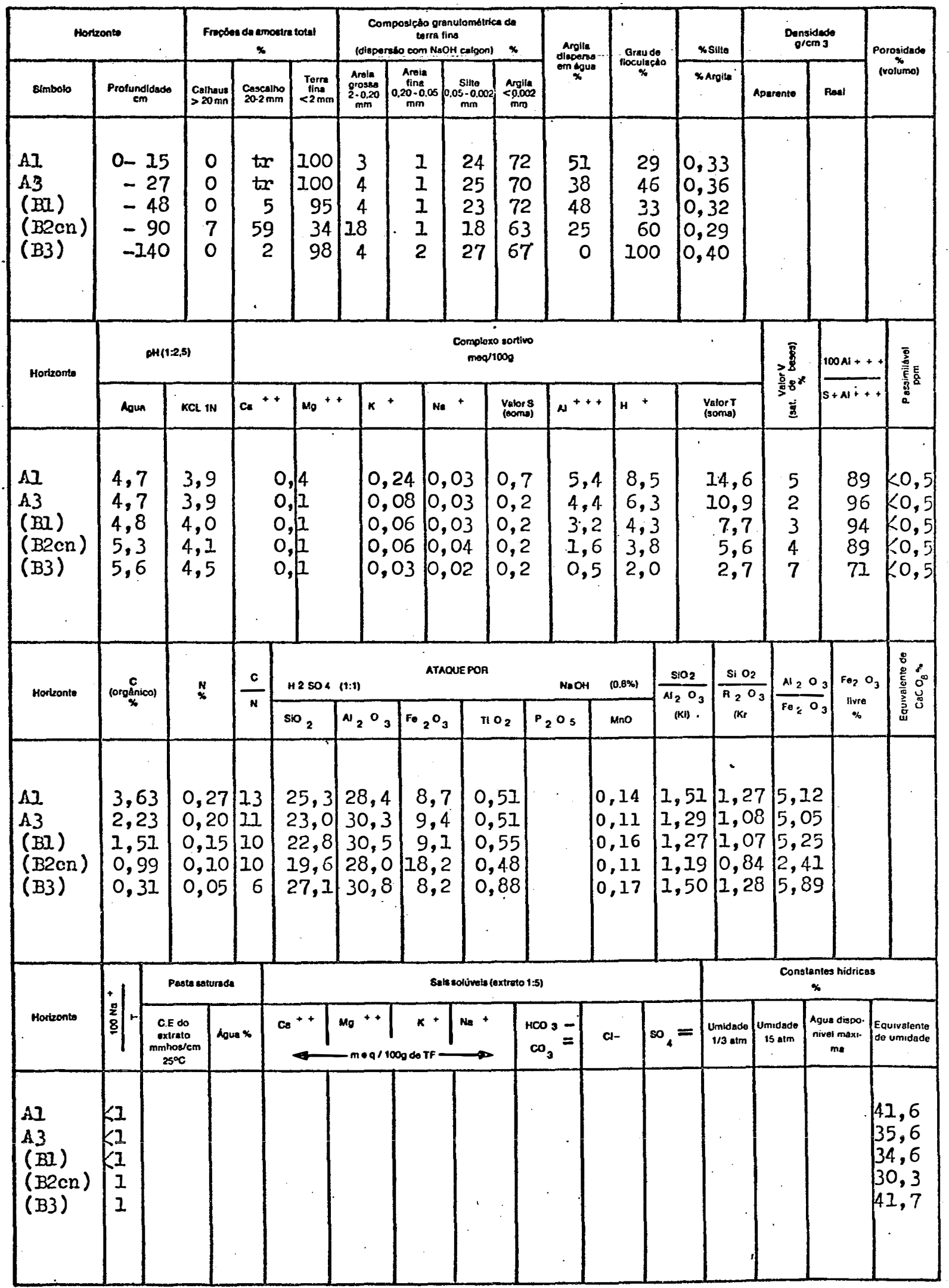


Perfil: $\quad$ PC -7

Data:

$26 / 07 / 81$

Classificação: TERRA BRUNA ESTRUTURADA ÁLICA argila de baixa atividade $A$ proeminente muito argiloso fase campo cerrado relevo suave ondulado (LATOSSOLO BRUNO ÁLICO A proeminente muito argiloso fase campo cerrado relevo suave ondulado).

Unidade de mapeamento:

Localização, município, estado e coordenadas: A $31 \mathrm{~km}$ de Po. ços de Caldas, na estrada para Andradas, $1 \mathrm{~km}$ na estrada para Pocinhos e $500 \mathrm{~m}$ à esquerda desta última. Andradas, MG.

Situação, declive e cobertura vegetal sobre o perfil: Trincheira no terço inferior da encosta, em declí ve de $3,5 \%$, sob vegetação de campo natural.

Altitude: $\quad 1280 \mathrm{~m}$.

Litologia: Rochas alcalinas.

Formação geológica: Complexo alcalino de Poços de Caldas. Cronologia: Cretāceo (?).

Material originārio: Matẹrial resultante da alteração de la vas fonoliticas e foiaitos com lentes de anfi bolitos.

Pedregosidade: Não pedregosa. 
Rochosidade: Não rochosa.

Relevo local: Suave ondulado.

Relevo regional: Forte ondulado.

Erosão: , Ligeira.

Drenagem: $\quad$ Bem drenado.

Vegetação primária: Campo cerrado.

Uso atual: Pasto natural.

Clima: Mesotérmico brando subúmido.

Descrito e coletado por: Tarcísio Ewerton Rodrigues e Humber to Gonçalves dos Santos.

Al 0- $15 \mathrm{~cm}$; bruno escuro (lOYR 3/3, úmido) e bruno amarelado (1OYR 5/4, seco); muito argiloso; forte pequena e média granular e bloco subangular ; muito duro, firme, muito plástico e muito pega joso; transição plana e gradual.

A3 15- $24 \mathrm{~cm}$; bruno escuro (10YR 4/3, úmido) e bruno amarelado (1OYR 5/4, seco); muito argiloso; forte pequena e média bloco subangular e granular; su perfície fosca (?); extremamente duro; firme , muito plástico e muito pegajoso; transição plą na e difusa. 
B21 24- $57 \mathrm{~cm}$; bruno escuro (7,5YR 4/4, úmido); muito argi loso; moderada a forte pequena a grande bloco subangular; cerosidade fraca e comum (?); extremamente duro, firme, muito plástico e muito pegajoso; transição plana e difusa.

B22 57-104 cm; bruno forte (7,5YR 7/7, úmido); muito argiloso; moderada média e grande bloco subangular; cerosidade fraca e comum (?); extremamente duro, firme, muito plástico e muito pegajoso;tran sição plana e difusa.

B23 104-140 cm; bruno forte (7,5YR 5/6, úmido) e. vermelho amarelo (5YR 5/6, úmido); muito argiloso; mode rada pequena e média bloco subangular; cerosidade fraca e comum (?); friável a firme, muito plástico e muito pegajoso; transição plana e abrupta.

Abl 140-175 cm; bruno muito escuro (lOYR 2/2, úmido) e bruno acinzentado muito escuro (10YR $3 / 2$, seco) ; muito argiloso; moderada pequena e média granu lar; extremamente duro, friável a firme, muito plástico e muito pegajosoi transição plana e abrupta.

Bb2 175-265+cm; vermelho (2,5YR 4/8, úmido); muito argiloso; muito plástico e muito pegajoso.

Raĩzes:

Finas abundantes no $\mathrm{Al}$; muitas no A3, B2l e B22 comuns no B23 e poucas no Abl. 
Observações: Poros: muito pequeno a médio muitos no Al, A3 e B21; muito pequeno e pequeno muitos no B22, B23 e Abl.

Presença de concreções dispersas em linha - no topo do $\mathrm{Abl}$ na base do $\mathrm{Bb} 2$ não permitindo a passagem do trado. A atividade de organișmo é comum no perfil. Em cortes com o solo seco a estrutura é prismática e bem estruturada. 0 Bb2 foi coletado com trado. A cerosidade não é observada no solo seco. 
PERFIL

PC-7

ANALISES FISICASE QUIMICAS

Amostra de labor. n.o: $\quad 81.1652 / 1658$

\begin{tabular}{|c|c|c|c|c|c|c|c|c|c|c|c|c|c|c|c|c|}
\hline \multicolumn{3}{|c|}{ Mortzontso } & \multicolumn{3}{|c|}{$\begin{array}{l}\text { Frecoses de emostra tolal } \\
\qquad x\end{array}$} & \multicolumn{4}{|c|}{ 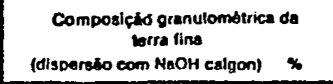 } & \multirow{2}{*}{ 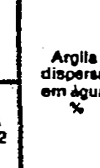 } & \multirow{2}{*}{ 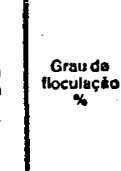 } & & \multirow{2}{*}{$\frac{x \text { sitra }}{\text { xargiles }}$} & \multicolumn{2}{|c|}{$\begin{array}{l}\text { Denstemoso } \\
\text { oflcm 3 }\end{array}$} & \multirow{2}{*}{$\begin{array}{l}\text { Porosidado } \\
\text { othmo) } \\
\text { (voluma }\end{array}$} \\
\hline simboto & $\begin{array}{l}\text { Proflund } \\
\text { con }\end{array}$ & & $\begin{array}{c}\text { collaws } \\
>20 \mathrm{mn} \\
\end{array}$ & 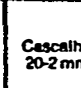 & $\begin{array}{l}\text { Torre } \\
\text { sind } \\
<2 \mathrm{~mm}\end{array}$ & $\begin{array}{l}\text { Arsis } \\
\text { gross } \\
2.0 .20 \\
\mathrm{~mm}\end{array}$ & 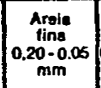 & 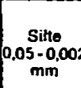 & 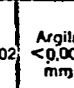 & & & & & Aparensto & Reol & \\
\hline $\begin{array}{l}\mathrm{A} 1 \\
\mathrm{~A} 3 \\
\mathrm{~B} 21 \\
\mathrm{~B} 22 \\
\mathrm{~B} 23 \\
\mathrm{Ab1} \\
\mathrm{Bb} 2\end{array}$ & $\begin{array}{l}0- \\
- \\
- \\
-1 \\
-1 \\
-1 \\
-2\end{array}$ & $\begin{array}{l}15 \\
24 \\
57 \\
04 \\
40 \\
75 \\
65+\end{array}$ & $\begin{array}{l}1 \\
0 \\
0 \\
0 \\
0 \\
0 \\
1\end{array}$ & $\begin{array}{l}3 \\
\operatorname{tr} \\
\operatorname{tr} \\
\operatorname{tr} \\
7 \\
1 \\
6\end{array}$ & $\begin{array}{r}96 \\
100 \\
100 \\
100 \\
99 \\
99 \\
93\end{array}$ & $\begin{array}{r}6 \\
4 \\
3 \\
4 \\
3 \\
15 \\
4\end{array}$ & $\begin{array}{l}3 \\
2 \\
2 \\
2 \\
1 \\
2 \\
1\end{array}$ & $\begin{array}{l}23 \\
20 \\
16 \\
14 \\
13 \\
17 \\
18\end{array}$ & $\begin{array}{l}68 \\
74 \\
79 \\
80 \\
83 \\
66 \\
77\end{array}$ & $\begin{array}{l}8 \\
4 \\
9 \\
0 \\
3 \\
6 \\
7\end{array}$ & $\begin{array}{r}3 \\
2 \\
9 \\
1 \\
1 \\
3 \\
10\end{array}$ & \begin{tabular}{l|l}
7 & 0, \\
8 & 0, \\
0 & 0, \\
3 & 0, \\
3 & 0, \\
9 & 0, \\
0 & 0,
\end{tabular} & $\begin{array}{l}34 \\
27 \\
20 \\
18 \\
16 \\
26 \\
23\end{array}$ & & & \\
\hline \multirow{2}{*}{ Hortzonto } & \multicolumn{3}{|c|}{ DH(1:2.25) } & \multicolumn{10}{|c|}{$\begin{array}{l}\text { Comploxí sontivo } \\
\text { moq/1009 }\end{array}$} & \multirow{2}{*}{ 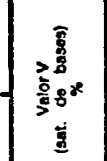 } & \multirow{2}{*}{$\int \frac{100 N++}{S+N i++}$} & \multirow{2}{*}{ 焉 } \\
\hline & nown & & CL IN & $\mathrm{ces}^{++}$ & $\mu_{0}+$ & $k^{+}$ & No & + & $\begin{array}{l}\text { Valor: } \\
\text { forme }\end{array}$ & is) $\mathrm{Al}^{+}$ & $++\mathrm{H}^{+}$ & & $\begin{array}{l}\text { valor } \mathrm{r} \\
\text { (soms) }\end{array}$ & & & \\
\hline $\begin{array}{l}\mathrm{Al} \\
\mathrm{A} 3 \\
\mathrm{~B} 21 \\
\mathrm{~B} 22 \\
\mathrm{~B} 23 \\
\mathrm{AbI} \\
\mathrm{BbC}\end{array}$ & $\begin{array}{l}4,8 \\
4,8 \\
5,0 \\
5,1 \\
5,0 \\
5,4 \\
5,8\end{array}$ & & 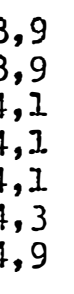 & &,$\left\{\begin{array}{l}\frac{3}{1} \\
\frac{1}{1} \\
\frac{1}{2} \\
\frac{1}{2}\end{array}\right.$ & & $\begin{array}{ll}, 19 & 0, \\
, 09 & 0, \\
04 & 0, \\
03 & 0, \\
04 & 0, \\
03 & 0, \\
04 & 0,\end{array}$ & $\begin{array}{l}05 \\
03 \\
03 \\
02 \\
03 \\
03 \\
07 \\
04\end{array}$ & $\begin{array}{l}0,5 \\
0,2 \\
0,2 \\
0,2 \\
0,2 \\
0,2 \\
0,2\end{array}$ & $\begin{array}{l}4 \\
4 \\
3 \\
3 \\
2 \\
2 \\
0\end{array}$ & \begin{tabular}{r|r}
, 4 & 7 \\
0 & 6 \\
, 3 & 4 \\
, 1 & 4 \\
9 & 4 \\
, 3 & 12 \\
1 & 3
\end{tabular} & $\begin{array}{l}, 7 \\
, 3 \\
, 3 \\
, 2 \\
, 7 \\
0 \\
0\end{array}$ & $\begin{array}{r}12,6 \\
10,5 \\
7,8 \\
7,5 \\
7,8 \\
14,5 \\
3,3\end{array}$ & $\begin{array}{l}4 \\
2 \\
3 \\
3 \\
3 \\
1 \\
6\end{array}$ & $\begin{array}{l}90 \\
95 \\
94 \\
94 \\
94 \\
92 \\
33\end{array}$ & $\begin{array}{l}k 0,5 \\
k 0,5 \\
k 0,5 \\
k 0,5 \\
k 0,5 \\
k 0,5 \\
k 0,5\end{array}$ \\
\hline \multirow[t]{2}{*}{ Morkonto } & \multirow{2}{*}{ (orodinicos) } & \multirow{2}{*}{\multicolumn{2}{|c|}{$\underset{\mathbf{W}}{\mathbf{N}}$}} & \multirow{2}{*}{$\frac{C}{N}$} & \multicolumn{5}{|c|}{ ATAQUEPOR } & \multicolumn{2}{|c|}{$\mathrm{NaOH}$} & \multirow{2}{*}{ 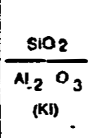 } & \multirow{2}{*}{ 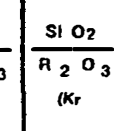 } & \multirow{2}{*}{$-\frac{\mathrm{A}_{2}}{\mathrm{O}_{2}} \mathrm{O}_{3}$} & \multirow{2}{*}{$\begin{array}{l}\mathrm{Fe}_{2} \mathrm{O}_{3} \\
\text { livro } \\
\times\end{array}$} & \multirow{2}{*}{$\mid$} \\
\hline & & & & & $\mathrm{SiO}_{2}$ & $\mathrm{Al}_{2} \mathrm{O}_{3}$ & ${ }_{3} \mathrm{Fe}_{2} \mathrm{O}_{3}$ & & $\mathrm{O}_{2}$ & $\mathrm{P}_{2} \mathrm{O}_{5}$ & Mno & & & & & \\
\hline \multirow[t]{2}{*}{$\begin{array}{l}\mathrm{AI} \\
\mathrm{A} 3 \\
\mathrm{~B} 2 \mathrm{I} \\
\mathrm{B} 22 \\
\mathrm{~B} 23 \\
\mathrm{ABI} \\
\mathrm{BbC}\end{array}$} & $\begin{array}{l}2,88 \\
1,99 \\
1,06 \\
1,04 \\
1,07 \\
2,59 \\
0,42\end{array}$ & \multicolumn{2}{|c|}{$\begin{array}{l}0,23 \\
0,17 \\
0,10 \\
0,10 \\
0,12 \\
0,25 \\
0,06\end{array}$} & $\begin{array}{r}13 \\
12 \\
11 \\
10 \\
9 \\
10 \\
7\end{array}$ & $\begin{array}{l}24,7 \\
25,3 \\
25,2 \\
26,8 \\
25,4 \\
23,9 \\
22,0\end{array}$ & $\begin{array}{l}28,6 \\
29,0 \\
29,1 \\
29,8 \\
29,6 \\
29,1 \\
30,9\end{array}$ & \begin{tabular}{l|r}
5 & 9, \\
0 & 8, \\
1 & 9, \\
8 & 9, \\
5 & 9, \\
1 & 11, \\
9 & 10,
\end{tabular} & $\begin{array}{l}0, \\
0 \\
0, \\
0 \\
0 \\
0 \\
0\end{array}$ & $\begin{array}{l}, 53 \\
, 51 \\
, 61 \\
, 63 \\
, 70 \\
, 64 \\
, 58\end{array}$ & & $\begin{array}{l}0,15 \\
0,13 \\
0,20 \\
0,14 \\
0,26 \\
0,10 \\
0,18\end{array}$ & $\begin{array}{l}1,47 \\
1,48 \\
1,47 \\
1,53 \\
1,45 \\
1,40 \\
1,21\end{array}$ & \begin{tabular}{l|l}
7,22 \\
3 \\
7,22 \\
7,22 \\
3 \\
5 \\
1,28 \\
1,21 \\
1,12 \\
0,92
\end{tabular} & \multicolumn{2}{|c|}{\begin{tabular}{l|l}
2 & 4,83 \\
24 & 5,21 \\
2 & 4,80 \\
8 & 5,74 \\
2 & 4,79 \\
2 & 4,08 \\
39 & 4,53
\end{tabular}} & \\
\hline & \multirow{2}{*}{\begin{tabular}{l|l|} 
& \\
$z$ & \\
8 & 1
\end{tabular}} & \multicolumn{2}{|c|}{ Peste sefurende } & \multicolumn{9}{|c|}{ Solbseotivests (extrnto 1:5) } & \multicolumn{4}{|c|}{$\begin{array}{l}\text { Constentes hitricas } \\
*\end{array}$} \\
\hline Hortzonto & & 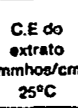 & $m$ & $u=8$ & $\mathrm{cos}^{++}$ & $m_{0}++$ & $x^{+}$ & No * & & $\mathrm{COO}_{3}=$ & c1- & $\mathrm{so}_{4}=$ & $\left|\begin{array}{c}\text { Umidade } \\
1 / 3 \text { atm }\end{array}\right|$. & $\begin{array}{l}\text { Umidade } \\
\text { is atm }\end{array}$ & $\begin{array}{c}\text { Agua disso- } \\
\text { nivel maxt- } \\
\text { me }\end{array}$ & $\begin{array}{l}\text { Equivalionte } \\
\text { dee unidade }\end{array}$ \\
\hline $\begin{array}{l}\mathrm{A} 1 \\
\mathrm{A3} \\
\mathrm{B} 21 \\
\mathrm{~B} 22 \\
\mathrm{~B} 23 \\
\mathrm{ABD} \\
\mathrm{Bb2}\end{array}$ & $\begin{array}{l}k I \\
k I \\
k I \\
k I \\
k I \\
k I \\
1\end{array}$ & & & & & & & & & & & & & & & $\begin{array}{l}37,6 \\
37,3 \\
37,6 \\
37,4 \\
37,4 \\
40,0 \\
40,3\end{array}$ \\
\hline
\end{tabular}


Perfil:

PC-8

Data:

$15 / 03 / 84$

Classificação: LATOSSOLO BRUNO Alico câmbico A moderado

Localização, município, estado e coordenadas: A $31 \mathrm{~km}$ de Poços de Caldas na estrada para Andradas, a $1 \mathrm{~km}$ desta em direção a Pocinhos e $500 \mathrm{~m}$ à esquerda desta última. Andradas, MG.

Situação, declive e cobertura vegetal sobre o perfil: Corte de estrada, em declive de $10 \%$, sob vegetação natural de campo cerrado.

Litologia: Rochas alcalinas.

Formação geológica: Complexo alcalino de Poços de Caldas.

Cronologia: Cretáceo.

Material originário: Material proveniente da alteração de la vas fonoliticas e foiaitos com lentes de anfibolitos.

Relevo local: Forte ondulado.

Relevo regional: Forte ondulado.

Erosão: $\quad$ Ligeira.

Drenagem: $\quad$ Bem a moderada.

Vegetação primāria: Campo cerrado. 
Uso atual: Pasto natural.

Descrito e coletado por: Tarcisio Ewerton Rodrigues e José Luiz I. Demattê.

A

B

$\mathrm{Ab}$

$\mathrm{Bb} 2$

$\mathrm{Bbc}$
$\mathrm{Bbl}$ - vermelho amarelado (5YR 4/6, úmido) muito argi

bruno escuro (10YR 4/3, úmido) e bruno (7,5YR 5/4, seco); muito argiloso; forte pequena e mé. dia granular e bloco subangular; extremamente đuro, firme, plástico e pegajoso.

bruno (7,5YR 5/4, úmido); muito argiloso; mode rada pequena a grande bloco subangular; extremamente duro, firme, plástico e pegajoso.

bruno acinzentado muito escuro (10YR $3 / 2$, úmido) bruno $(7,5 Y R 5 / 3$, seco); muito argiloso ; forte pequena e média granular e bloco subangu lar; extremamente duro, firme, plástico e pega joso. loso; moderada média a grande bloco subangular; extremamente duro, firme, plástico e pegajoso.

brunc forte $(7,5 \mathrm{YR}$ 5/6, úmido); muito argiloso; moderada média a grande bloco subangular; extremamente duro, firme, plástico e pegajoso.

bruno forte (7,5YR 5/6, úmido); muito argiloso; moderada pequena a grande bloco subangular; extremamente duro, firme, plástico e pegajoso.

Observações: Presença de fragmentos de rocha na superfície. 
PERFIL PC- 8

NULISES FISICASE QUIMICAS

Amostra de lator. n.o: $\quad 84.0742 / 0.747$

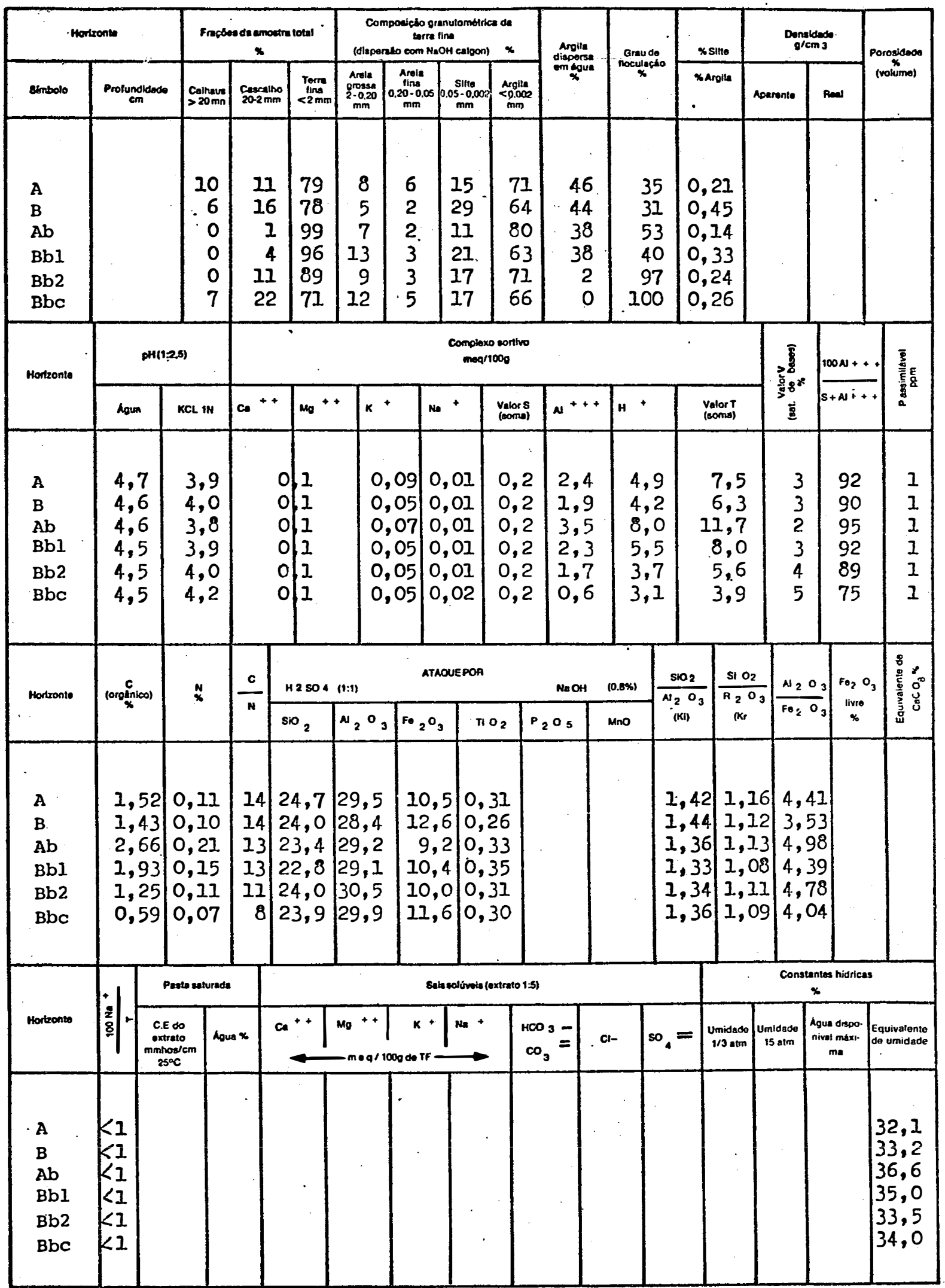


230.

APENDICE II 


\section{DESCRIÇÃO MICROMORFOLŐGICA}

\section{PERFIL PC-1}

Horizonte: $\quad \mathrm{Au} / \mathrm{AB}$

Esqueleto e litorelictos: Feldspato e quartzo comuns. Litore lictos poucos.

Matriz do solo: Fabrica plasma argilasepica bruno amarelada numa distribuição relatada porfiroesquelética.

Vasios: $\quad$ Canais, cavidades, fissuras comuns; orto e metavughs, meta-skew planes, simple packing voids.

Feições pedológicas: Nódulos de ferro e argila, amarelo, ve melho e preto; presença de raízes. Pouco argilans, ferri-argilans e sesquans, de segregação (formados pelo intemperismo), ao redor dos grãos de esqueleto e nódulos do solo; sesquans nos canais e fraturas do esqueleto em altera ção. Cristalaria, dispersa, gibbsitica. Fissuras resultante da retração do solo. Pseudo morfos?

Horizonte: Bwl

Esqueleto e litorelictos: Feldspato e quartzo comuns. Litore lictos poucos.

Matriz do solo: Fabrica plasma argilasepica amarelo brunado numa distribuição relatada porfiroesquelética. 
Vasios :

Canais, cavidades e fissuras comuns; orto - e metavughs smooth-metavughs, meta-skew planes , simples packing voids.

Feições pedológicas: Nódulos de ferro, manganês, aluminio e argila, preto a amarelo claro; presença de raízes. Poucos argilans, ferri-argilans, mangans, de segregação, ao redor de grãos do esqueleto e nódulos do solo, sesquans em canais e fraturas do esqueleto em alteração: Cristalaria, disper sa, gibbsitica. Fissuras de retração do solo. Estrutura herdada do fraturamento do esqueleto. Pseudomorfos?

Horizonte:

Bw2

Esqueleto e litorelictos: Feldspato poucos e quartzo comuns. Litorelictos poucos.

Matriz do solo: Fabrica plasma insēpica bruno forte numa dis tribuição relatada porfiro esquelética.

Vasios :

Canais, cavidades e fissuras comuns; ortho- e metavughs, smooth-metavughs, meta-skew planes e simple packing voids.

Feições pedológicas: Nódulos de ferro, argila, alumínio, pre to a amarelo claro.comuns argilans, ferri-argi lans e seṣquans de segregação, ao redor dos grãos do esqueleto e nódulos do solo, canais e fraturas do esqueleto em alteração. Cristalaria, dispersa, gibbsitica. Estrutura herdada do fraturamento do esqueleto. Fissuras de retenção do solo. Pseudomorfos? 
Horizonte: $\quad B C$.

Esqueleto e litorelictos: Feldspato e quartzo comuns. Litorelictos comuns.

Matriz do solo: Fabrica plasma insépica vermelho amarelado numa distribuição relatada porfiroesquelética.

Vasios:

Canais, cavidades e fissuras comuns; ortho- e metavughs, smooth-meta-vughs, meta-skew planes e simples packing voids.

Feições pedológicas: Nódulos de ferro, manganês, argila e alumino; preto a amarelo claro. Comuns, argilans, ferri-argilans, mangans e sesquans, de segregação (formada pelo intemperismo) ao redor de grãos de esqueleto e nódulos do solo e em canais e fraturas do esqueleto em intemperi zação. Cristalaria em canais e nódulos, gibbsítica. Fissuras de retração do solo. Mirmequita (?). Pseudomorfos (?).

Horizonte :

Cl

Esqueleto e litorelictos: Feldspato e quartzo poucos. Litore lictos comuns.

Matriz do solo: Fabrica plasma argilasépica a insépica verme lho amarelıado numa distribuição relatada porfí roesquelētica.

Vasios: Canais, cavidades e fissuras; ortho - e metavughs, smooth-meta-vughs, meta-skew planes e simple packing voids. 
Feições pedológicas: Nódulos de ferro, manganês, argila e alumínio, preto a amarelo claro. Comuns gibbsans, argilans, ferri-argilans, mangâns, de segregação (formada pelo intemperismo) ao redor dos grãos do esqueleto e nódulos do solo e em canais e fraturas do esqueleto em alteração. Cristalaria (gibbsans) em canais, nódulos e dispersa, gibbsítica. Separações plasmáticas com dominância de cristais e menos sesquans. Pseudomorfos?

Horizonte: $\quad$ Cl rocha alterada

Esqueleto e litorelictos: Feldspato e quartzo poucos. Litore lictos comuns.

Matriz do solo: Fabrica plasma argilasépica, silasépica e cristica cinza a vermelha numa distribuição re latada porfiroesquelética. .

Vasios: Canais, cavidades e fissuras comuns; ortho- e metavughs, smooth-meta vughs, meta-skew pla nes.

Feições pedológicas: Nódulos de ferro, argila, manganês e alumínio, preto a branco. Comuns gibbsans, fer riargilans, silans, sesquans, mangâns, de segregação (formada por intemperismo) ao redor dos grãos de esqueleto e nódulos do solo e em canais e fissuras. Cristalaria, em canais, nó dulos e dispersa, gibbsítica, Separação plasmā tica com cristais pequenos, clara; outra cinza escura, com cristais muito pequenos recobertos por material amorfo e uma avermelhada,com sesquans recobrindo os cristais. Pseudomorfos? 
RERFIL PC-2

Horizonte:

Aup

Esqueleto e litorelictos: Fabrica plasma argilasépica e insé pica bruno uma distribuição relatada porfiroesquelética.

Vasios: Canais, cavidades e fissuras comuns; ortho - e metavughs, smooth-metavughs, meta-skew planes e simple packing voids.

Feições pedológicas: Nódulos de ferro, manganês e argila, pre to a bruno amarelado. Poucos argilans, ferrans, ferri-argilans, mangans e silans, de segrega ção (formado pelo intemperismo) ao redor dos grãos do esqueleto e nódulos do solo e em canais e fissuras. Cristalaria dispersa gibbsiti ca. Organs e sesquans envolvendo os agregados muito pequenos. O plasma apresenta-se com mui tos agregados sugerindo herança do fraturamento do material de partida. Nódulos de cristais (gibbsita) envolto por óxidos de ferro. Pseudomorfos? Fissuras de retração.

Horizonte: $\quad A B$

Esqueleto e litorelictos: Quartzo comuns e feldspatos poucos. Litorelictos poucos.

Matriz do solo: Fabrica plasma latissépica bruno forte numa distribuição relatada porfiroesquelética. 
Vasios :

Canais, cavidades e fissuras comuns; ortho- e metavughs, smooth, metavughs, meta-skew planes e simple packing voids.

Feições pedológicas: Nódulos de ferro, argila, manganês, e alumínio, preto a amarelo claro. Comuns argilans, ferri-argilans, sesquans, mangans, de segregação' (formado pelo intemperismo) ao redor dos grãos do esqueleto e nódulos do solo, em canais e fissura? Cristalaria, em nódulos e dispersa, gibbsitica. Presença de papulas de segregação (pressão). Plasma muito agregado possivelmente herdado das fraturas do material de partida. Sesquans recobrindo grão do esqueleto e preechendo vasios entre agregados. Fissuras de retração do solo. Pseudomorfos?

Horizonte: $\quad$ Bwl

Esqueleto e litorelictos: Quartzo e feldspatos poucos. Lito relictos poucos.

Matriz do solo: Fabrica plasma latisepica vermelho amarelada numa distribuição relatada porfiroesquelética.

Vasios:

Canais, cavidades e fissuras comuns; ortho - e metavughs; smooth-metavughs, meta-skew planes e simple packing voids.

Feições pedológicas: Nódulos de ferro, manganês, argila e alụ mínio, preto a amarelo claro. Comuns argilans, ferri-argilans, mangans, sesquans e silans, de 
segregação (formado pelo intemperismo) ao redor dos grãos do esqueleto e nódulos do solo e em canais e fissura. Papulas de intemperização . Cristalaria, em nódulos e dispersa, gibbsitica. Nódulos gibbsíticos coloridos e envolto por óxi dos de ferro. Fissuras de retração do solo. Pseudomorfos? Gibbsita I.

Horizonte: $\quad$ Bं'2

Esqueleto e litorelictos: Quartzo comuns e feldspatos poucos. Litorelictos poucos.

Matriz do solo: Fabrica plasma latisepica vermelho amarelado numa distribuição relatada porfiroesquelética.

Vasios: Canais, cavidades e fissuras comuns; ortho - e metavughs, smooth-metavughs, meta-skew planes e simple packing voids.

Feições pedológicas: Nódulos de ferro, alumínio, argila e manganês, preto a amarelo claro. Comuns argi lans, ferri-argilans, mangans, silans (?) e gibbsans, de segregação, ao redor dos grãos do esqueleto e nódulos do solo e em canais e fissuras. Glebulas argilosas (papulas) de intempe rismo com limites pouco nítidos. Cristalaria, dispersa e em nódulos, gibbsítica. Ocorre con creções de ferro. Fissuras de retração da mas sa do solo. Pseudomorfos? Presença de estrutura. Muitos argilans de segregação. 
Horizonte: $\quad B C$

Esqueleto e litorelictos: Quartzo comuns e feldspatos poucos. Iitorelictos poucos.

Matriz do solo: Fabrica plasma latissepica cinza claro numa distribuição relatadạ porfiroesquelética.

Vasios:

Canais, cavidades e fissuras, ortho - e meta vughs, smooth-metavughs, meta skew planes e simple packing voids.

Feições pedológicas: Nódulos e concreções de ferro vermelho escuro. Poucos argilans, ferri-argilans e sesquans, de segregação, em torno dos grãos do es queleto e nódulos do solo e em canais e fissuras. Cristalaria, dispersa e em nódulos,giḅ bsítica. Fissuras de retração da massa do so10, muitas.

PERFIL PC-3

Horizonte: Aup

Esqueleto e litorelictos: Quartzo poucos, litorelictos poucos.

Matriz do solo: Fabrica plasma argilasépica bruno amarelado numa distribuição relatada porfiroesquelética.

Vasios:

Canais, cavidades e fissuras comuns: ortho- e metavughis, smooth-metavughs, meta-skew e simple packing voids. 
Feições pedológicas: Nódulos de ferro e argila comuns; concre ções de ferro poucas. Poucos argilans, sesquans, ferri-argilans e silans, de segregação , em torno do grãos do esqueleto e nódulos do solo e em canais. Mineral fraturado e intemperizado recoberto por sesquans. Oxidos de Mn e Ti. Presença de raízes. Fissuras de retração da massa do solo. Estrutura - agregados muito pequenos.

Horizonte:

$\mathrm{AB}$

Esqueleto e litorelictos: Quartzo comuns, feldspatos poucos. Litorelictos poucos.

Matriz do solo: Fabrica plasma insepica bruno forte numa distribuição relatada porfiroesquelētica.

Vasios: Canais, cavidades e fissuras comuns; ortho - e metavughs, smooth-metavughs, meta skew planes e simple packing voids.

Feições pedológicas: Nódulos e concreções de ferro, manganês, argila e alumínio: Comuns argilans, ferri-argi lans, sesquans e silans, de segregação, em torno dos grãos do esqueleto e nódulos do solo e em canais e fissuras. Fissuras de retração da massa do solo. Material amorfo revestindo superfícies de agregados. 
Horizonte:

BA

Esqueleto e litorelicto: Quartzo comuns. Litorelicto poucos.

Matriz do solo: Fabrica plasma in sépica e latisépica vermelho amarelado numa distribuição relatada porfiṛoesquelética.

Vasios: Canais, cavidades e fissuras comuns; ortho - e metavughs, smooth-metavughs, meta skew planes e simple packing voids.

Feições pedológicas: Nódulos de ferro e argila, comuns. Con creções de ferro poucas. Pouco argilans e sesquans, de segregação, ao redor dos grãos de esqueleto e nódulos do solo e em canais. Glaebu las argilosas (papulas) formada pelo intemperí mo. Litorelicto proveniente de intemperização de material impregnado por sesquans. Cristalaria, dispersa e em nódulos, giibbsítica. Pseudomorfos.

Horizonte: Bwl

Esqueleto e litorelictos: Quartzo comuns. Litorelicto poucos.

Matriz do solo: Fabrica plasma latisépica amarelo avermelhado numa distribuição relatada porfiroesquelética.

Vasios: Canais, cavidades comuns e fissuras poucas; ortho - e metavughs, smooth-metavughs, meta-skew planes e simple packing voids. 
Feições pedológicas: Nódulos de ferro e alumínio comuns. Con creções de ferro comuns. Poucos argilans e sesquans de segregação ao redor dos grãos do esqueleto e nódulos do solo e em canais. Cristalaria, dispersa e em nódulos, gibbsítica. Si lans? Solo estruturado.

Horizonte: $\quad$ Bw2

Esqueleto e litorelicto: Quartzo comuns e feldspatos(?). Litorelicto poucos.

Matriz do solo: Fabrica plasma latisépica vermelho amarelado numa distribuição relatada porfiroesquelética.

Vasios:

Canais, cavidades e fissuras comuns; ortho- $e$ metavughs, smooth-metavughs, meta-skew planes e simple packing voids.

Feições pedológicas: Nódulos de ferro, argila, manganês e alu mínio, muitos.Concreções de ferro muitas. Poucos argilans, ferri-argilans, sesquans e silans(?), de segriegação, ao redor dos grãos do esq̣ueleto e nódulos do solo e canais. Cristala ria, dispersa, em canais e nódulos, gibbsítica. Nódulo com cristais de gibbsita envolvido por sesquans. Horizonte estruturado com agregados grandes e pequenos. 
Horizonte: Bw3

Esqueleto e litorelicto: Quartzo comuns e feldspatos? Litore licto poucos.

Matriz do solo: Fabrica plasma latisépica vermelho amarelado numa distribuição relatada porfiroesquelética.

Vasios: $\quad$ Canais, cavidades e fissuras comuns; ortho - e metavughs, smooth-metavughs, meta-skew planes e simple packing voids.

Feições pedológicas: Nódulos de ferro, argilà e alumínio muí tos. Concreções de ferro comuns. Poucos argi lans, ferri-argilans, mangans, de segregação , ao redor dos grãos do esqueleto e nódulos do solo e em canais. Cristalaria, dispersas e em nódulos, gibbsitica. Nódulo formado por gibsita e material amorfos.

Horizonte: $\quad B C$

Esqueleto e litorelicto: Quartzo comuns e feldspatos? Litore licto poucos.

Matriz do solo: Fabrica plasma latisepica bruno forte numa distribuição relatada porfiroesquelética.

Vasios: $\quad$ Canais, cavidades e fissuras comuns, ortho - e metavughs, smooth-metavughs, meta-skew planes e simple packing voids. 
Feições pedológicas: Nódulos de ferro, argila, manganês e alumínio, muitos. Concreções de ferro comuns. Pouco argilans, ferrans, ferri-argilans, de se gregação, ao redor dos grãos do esqueleto e nó dulos do solo e em canais. Cristalaria, dis persa e em nódulos, gibbsítica. Litorelicto fra turado que lembra as fraturas do mineral de partida - estrutura herdada. Nódulos preenchidos por gibbista I, envolvido por sesquans. Mi neral intemperizando em BOXWORK? Pseudomorfos?

PERFIL PC- $\underline{4}$

Horizonte: Aup

Esqueleto e litorelicto: Quartzo e feldspatos poucos. Litore licto poucos.

Matriz do solo: Fabrica plasma argilasépica para isótica bru na numa distribuição relatada porfiroesquelétị ca.

Vasios: Canais e cavidades comuns; ortho- e meta vughs, smooth-metavughs, simple packing voids.

Feições pedológicas: Nódulos de ferro e argila, poucos. Con creções de ferro poucas. Poucas sesquans de segregação e organs ao redor dos grãos do es queleto e nódulos do solo e em canais e estrutura. Nódulos de cristais de gibbsita revestido por sesquans - material amorfos. Horizonte muito estruturado,preservada pela matéria orgâa nica. 
Horizonte :

Bwl

Esqueleto e litorelicto: Quartzo comuns e feldspatos poucos. Litorelictos poucos.

Matriz do solo: Fabrica plasma argilasepica a insépica bruno forte numa distribuição relatada porfiroesquelética.

Vasios:

Canais e cavidades comuns e fissuras poucas; or tho- e metavughs; smooth-metavughs, meta skew planes e simple packing voids.

Feições pedológicas: Nódulos de ferro, argila e alumínio, co muns. Concreções de ferro poucas. Comuns argilans, sesquans, ferriargilans e silans (?) , de segregação, ao redor do esqueleto e nódulos do solo e canais. Cristalaria, dispersa, em nódulos e vasios, gibbsita. Nódulo constituído por cristais de gibbsita com material amorfos recobrindo os mesmos com silans em volta do nódulo, sugerindo ressilicatização de gibbsita a argila. Pseudomorfos?

Horizonte: Bw2

Esqueleto e litorelicto: Quartzo e feldspato poucos. Litorelicto poucos.

Matriz do solo: Fabrica plasma latisepica bruno forte numa distribuição relatada porfiroesquelética.

Vasios:

Canais e cavidades comuns e fissuras poucas; $\underline{\text { r }}$ tho - e. metavughs; smooth-metavulghs; meta-skew planes e simple packing voids. 
Feições pedológicas: Nódulos de ferro, argila e aluminio comuns. Concreções de ferro poucas. Comuns argilans, ferriargilans, sesquans e silans, de segregação, ao redor de grãos do esqueleto e nódulos do solo. Cristalaria, em nódulos e canais, gibbsitica. Ocorrência de gibbsans. Horizonte estruturado: Sesquans ou material amor fos recobrindo partes do plasma com pequenos agregados, sugerindo que os mesmos estão preservando a estrutura herdada de mineral fraturado já alterado; enquanto que, onde : ocorre agregados maiores, não observa-se a cobertura de material amorfos ou sesquans.

Horizonte: $\quad$ Bw3

Esqueleto e litorelicto: Quartzo e feldspato poucos. Litore licto poucos.

Matriz do solo: Fabrica plasma insépica e latisépica verme tho amarelado numa distribuição relatada porfí roesquelética.

Vasios: $\quad$ Canais, cavidades e fissuras, muitas; ortho -e metavughs; smooth - metavughs; meta - skew pla nes e simple packing voids.

Feições pedológicas: Nódulos de ferro, argila e alumínio, co muns. Concreções de ferro poucas. Comuns argilans, sesquans, mangans e silans (?), de segregação, em volta de grãos de esqueleto e nódulos, gibbsitica. Glaebulas argilosa (papu le) de segregação. Mineral fraturado (feldspą 
to) em intemperização recoberto por material amorfos. Muitas fissuras de retração da massa do solo. Pseudomorfos.

Horizonte: $\quad B w 4$

Esqueleto e litorelicto: Quartzo e feldspato poucos. Litore licto, poucos.

Matiz do solo: Fabrica plasma insépica e latisépica bruno for te numa distribuição relatada porfiroesqueléti ca.

Vazios:

Canais, cavidades comuns e fissuras poucas; or tho- e metavughs, smooth-metavughs; meta-skew planes e simple packing voids.

Feições pedológicas: Nódulos de ferro, argila e aluminio comuns. Concreções de ferro poucas. Poucos argilans, sesquans, ferriargilans e silans (?), de segregação, em volta dos grãos de esqueleto e nódulos do solo. Cristalaria, dispersa e em nódulos, gibbsitica. Fraturas do mineral intemperizado preservadas por ferrans. Nódulos constituidos de cristais (gibbsita?) recobertos por óxidos de ferro. Pseudomorfos (?). 
PERFIL PC-5

Horizonte: Aec (Cascalhos)

Constituido por nódulos de óxidos de ferro e gibbsita I. Presença de feldspatos preservado por óxidos de ferro. Fabrica plasma normalmente isótico. Grande quantidade de gibbsans e ferrans e poucos mangans e argilans de segregação. Cristalaria de gibbsita em canais, em nódulos , câmaras e dispersas (cristal sheets, cristal câa maras e cristal tubo, aleatória, cristalografica e esferulítica). Ocorre nódulos com cristais recobertos por óxidos de ferro que lembra a fra tura do material de origem.

Em outra lâmina a matiz é constituída por óxidos de ferro e grandes cristais de gibbsita I, formando cristalaria e gibbsans - cristal sheets, cristal camara e cristal tubo. As cristalarias aparecem em faixas, canais e fissuras. Há cris talária envolvida por mangans. Observa-se uma sucessão de estratos de sesquans e gibbsans (cris talaria). Existência de gibbsita II recoberta por óxidos de ferro colorindo de vermelho amare lado.

Horizonte: $\quad B_{W}$

Esqueleto e Litorelicto: Quartzo e feldspato poucos. Litore..:licto poucos. 
Matiz do solo: Fabrica plasma latisépica-silasépica amarelo brunado numa distribuição relatada porfiroes quelética.

Vazios :

Canais e cavidades,comuns; ortho e metavughs , smooth-metavughs e simple packing voids.

Feições pedológicas: Nódulos de ferro, argilosa e alumino,co muns. Concreções de ferro poucas. Poucos ses quans, ferri-argilans e argilans, de segrega ção, em volta dos grãos do esqueleto e nódulos do solo. Cristalaria, em canais, nódulos e dis persa, gibbsitica. Horizonte constituído por agregados muito pequenos. O plasma parece ser constituido por cristais recobertos por mate rial amorfos-sesquans. Pseudomorfos (?) .

Horizonte:

$\mathrm{Cl}$

Esqueleto e litorelicto: Quartzo e feldspatos poucos. Litore licto pouco.

Matiz do solo: Fabrica plasma latisépica-selasépica bruno mi to claro, acinzentado numa distribuição relata da porfiroesquelética.

Vazios: Canais, cavidades e fissuras comuns; ortho e metavughs, smooth-metavughs, meta-skew planes e simple packing voids.

Feições pedológicas: Nódulos de ferro, argila e aluminio, co muns. Concreções de ferro poucas. Poucos ses 
quans, ferriargilans e argilans, de segregação, em volta dos grãos do esqueleto e nódulos do so 10 e em canais. Presença de argilans de possivel iluviação (papulas?), resultante da intem perização, revestindo paredes de litovazios. Cristalaria, dispersa e em nódulos, gibbsitica. o plasma dá o aspecto de ser formado por cristais recobertos por material amorfos-sesquans. Pseudomorfos (?).

\section{PERFIL PC-6}

Horizonte:

$\mathrm{Au}$

Esqueleto e litorelicto: Quartzo e feldspato poucos litorelic to poucos.

Matiz do solo: Fabrica plasma argilasépica bruno amarelado nu ma distribuição relatada porfiroesquelética.

Vazios :

Canais, cavidades e fissuras, comuns; ortho - e metavughs, smooth-metavughs, meta-skew planes e simple packing voids.

Feições pedológicas: Nódulos de ferro, argila e aluminio, comuns. Concreções de ferro comuns. Poucos ses quans e argilans, de segregação, em torno dos grãos do esqueleto e nódulos do solo e em canais. Gibbsans e cristalaria de gibbsita I, em cristal sheets, cristal tubo e em nódulo. Hori zonte estruturado e com muitas fissuras de retração da massa do solo. Pseudomorfos (?). 
Horizonte: $\quad A B$

Esqueleto e litorelicto: Quartzo e feldspato poucos. Litore licto poucos.

Matiz do solo: Fabrica plasma insépica amareḷo avermelhado numa distribuição relatada porfiroesquelética.

Vazios :

Canais, cavidades e fissuras, comuns; ortho -e metavughs, smooth-metavughs, meta-skew planes e simple packing voids.

Feições pedológicas: Nódulos de ferro e alumínio e manganês, comuns. Concreções de ferro poucas. Poucos a gilans, sesquans e silans, de segregação, ao redor dos grãos do esqueleto e nódulos do solo e em canais. Gibbsans e cristalaria de gibbsi ta - cristal camara, dispersa e em nódulo. Nódulos gibbsiticos resultantes da intemperiza ção do mineral, envolvidos por óxidos de ferro. Neoformação de argila pela ressilicatização de gibbsita em nódulos. Nódulos gibbsiticos reco bertos por sesquans. Fissuras de retração da massa do solo.

Horizonte: $\quad B A$

Esqueleto e litorelicto: Quartzo e feldspatos poucos. Litorelictos poucos.

Matiz do solo: Fabrica plasma insépica vermelho amarelado nu ma distribuição relatada porfiroesquelética. 
Vazios :

Canais, cavidades e fissuras, comuns, ortho e metavughs, smooth-metavughs, meta skew e sim ple packing voids.

Feições pedológicas: Nódulos de ferro, aluminio e argila, co muns. Concreções de ferro e manganês, comuns. Poucos sesquans, argilans e silans(?), de se gregação, em volta dos grãos de esqueleto e nō dulos do solo e em canais. Gibbsans e cristalaria de gibbsita, dispersas e em nódulos. Nódulos de ferro e gibbsita possivelmente transportado. Os nódulos encontrados no horizonte BwC. do perfil PC-6, são constituídos por óxidos de ferro e gibbsita impregnados por ses quans.

PERFIL PC-7

Horizonte: $\quad \hat{A u} / \hat{A B}$

Esqueleto e litorelicto: Quartzo e feldspato poucos. Litore licto poucos.

Matiz do solo: Fabrica plasma argilasépica a isótica bruno amarelado escuro numa distribuição relatada por firoesquelética.

Vazios:

Canais, cavidades e fissuras comuns; ortho - e metavughs, smooth-metavughs, meta-skew planes e simple packing voids. 
Feições pedológicas: Nódulos de ferro, argila e aluminio, co muns. Concreções de ferro comuns. Poucos ses quans e organs, em volta dos grãos do esqueleto e nódulos do solo e em canais e entre os elementos de estrutura.

Gibbsans e cristalaria de gibbsita, dispersa e em nódulos. Estrutura parece herdada do mineral fraturado que ao intemperizar transfere sua forma. Pseudomorfos?

Horizonte: $\quad$ Bwl

Esqueleto e litorelicto: Quartzo e feldspatos poucos. Litorelictos poucos.

Matiz do solo: Fabrica plasma insépica a latisépica bruno for te numa distribuição relatada porfiroesquelétí ca.

Vazios:

Canais, cavidades e fissuras comuns; ortho - e metavughs, smooth - metavughs, meta-skew planes e simple packing voids.

Feições pedológicas: Nódulos de ferro, aluminio e argilosa, comuns. Concreções de ferro comuns. Comuns argilans e sesquans, de segregação, ao redor dos grãos do esqueleto e nódulos do solo. Gibbsans e cristalaria de gibbsita I, dispersa,em canais e nódulos. Concreção com sucessão de argilans e ferri argilans. Feldspato fraturado em intemperização (pseudomorfos). Fissuras de retração da massa do solo. Nódulo com fratu ras. 
Horizonte:

Bw2

Esqueleto e litorelicto: Quartzo e feldspatos poucos: Litorelicto poucos.

Matiz do solo: Fabrica plasma insépica a latisépica amarela numa distribuição relatada porfiroesquelética.

Vazios:

Canais; cavidades e fissuras comuns, ortho - e metavughs, smooth-metavughs, meta -skew pla nes e simple packing voids.

Feições pedológiças: Nódulos de ferro, aluminio e argila, co muns. Concreções de ferro comuns. Comuns sesquans e argilans, de segregação, em volta dos grãos do esqueleto e nódulos do solo e em canais. Gibbsans e cristalaria de gibbsita. em canais, nódulos e dispersa. Nódulo (glaebula) constituida por ferriargilans. Horizonte estruturado com sesquans preenchendo fissuras.Mi neral (feldspato) intemperizando(?) com mate rial amorfo recobrindo-o. Pseudomorfos (?). Muitos nódulos com cristais de gibbsita.

Horizonte: Bw3.

Esqueleto e litorelicto: Quartzo e feldspato poucos. Litore licto poucos.

Matiz do solo: Fabrica plasma latisépica amarelo avermelhado numa distribuição relatada porfiroesquelética. 
Vazios:

Canais, cavidades e fissuras, comuns; ortho-e metavughs, smooth - metavughs, meta - skew pla nes e simple packing voids.

Feições pedológicas: Nódulos de ferro, alumínio e argila, co muns. Concreções de ferro comuns. Comuns a muitos argilans e sesquans, de segregação, em volta de grãos do esqueleto e nódulos do solo. Gibbsans e cristalaria de gibbsita em nódulos e cristais isolados. Neste horizonte o plasma è mais orientado que os horizontes superiores. Menor quantidade de nódulos com cristais de gibbsita que os horizontes anteriores. Glae bula (papula) argilosa. Fissuras de retração da massa do solo.

Horizonte: $\mathrm{Au}$

Esqueleto e litorelicto: Quartzo e feldspato poucos.

Matiz do solo: Fabrica plasma argilasépica a isótica bruno amarelado numa distribuição relatada porfiroes quelētica.

Vazios: Canais, cavidades e fissuras, comuns; ortho - e metavughs; smooth - metavughs; meta - skew pla nes e simple packing voids.

Feições pedológicas: Nódulos de ferro, aluminio e argila, co muns. Concreções de ferro poucas. Muitos sesquans, silans, de segregação, ao redor dos grãos do esqueleto e nódulos do solo. Gibbsans e cristalaria de gibbsita em cristais disper - 
sos, nôdulos e canais. Horizonte totalmente estruturado. Mineral fraturado (feldspato ou pseudomorfo) recoberto por sesquans. A matēria orgânica preservou a estruturação herdada do material de origem. Raízes e micélios de fungos? 